\title{
De Geschiedenis van het Londensch Tractaat van 17 Maart 1824.
}

\author{
DOOR \\ P. H. VAN DER KEMP.
}

„No cant betrays more ignorance than that which affects to "undervalue the qualities of public men in the march of public naffairs. However circumstances may contribute to make indivi"duals, individuals have as great a share in making circumstances." bl. 239 .

Sir Henry Lytton Bulwer: Historical Characters dl. II (1868)

"The true historian, however much he may feel inclined to ${ }_{n}$ see in history, as in nature, a process of evolution, cannot and "ought not to forget the individuals who act or who suffer in "the birth and death struggles of humanity. If he did, he "would deprive history of all its human interest, of its dramatie "character, and its moral lessons."

F. Max Müller: The Nineteenth Century May 1897 bl. 714 . Wetenschappelïke Bladen Januari 1898 bl. 93. 


\section{INLEIDING.}

Jaren geleden vatte ik het plan op tot het schrijven dezer geschiedenis. De voorbereidende studiën hiervoor makende, kreeg ik in toenemende mate de overtuiging, dat voor de degelijkheid van dien arbeid onmisbaar waren én eene destijds nog niet bestaande geschiedenis van het Londensch koloniaal tractaat van 1814 én eene breede kennis van de daarop gevolgde gebeurtenissen, die tot zoovele oneenigheden met de Engelschen in Indië hebben geleid. Hiervoor stond met hooggewaardeerde welwillendheid het archief van het departement van Koloniën tot zekere grens ter mijner beschikking; doch het groote bezwaar was, dat men uit den aard der zaak wel de stukken, waaraan behoefte gevoeld werd, kon vragen, echter niet zelf de archiefbundels van het tijdvak doorloopen om er uit te trekken wat noodig geacht mocht worden; voor zulk eene meer zekere behandeling is noodig eene rangschikking der stukken, gelijk men op het Rijksarchief in acht neemt. Aan deze moeilijkheid werd echter te gemoet gekomen door het aanzoek in die dagen van het bestuur van het Koninklijk Institunt voor de TaalLand- en Volkenkunde van Nederlandsch-Indië, of ik genegen zou zijn voor deze instelling te bewerken de stukken, die door Mr. W. Roosegaarde Bisschop voor het Instituut en met subsidie van Koloniën, getrokken waren uit het India Office te Londen (a). Daar die stukken juist over het door mij bedoelde tijdperk liepen, nam ik de uitnoodiging bijzonder gaarne aan; ik had er te meer reden van voldoening over, omdat ik nu door deze verzameling in de gelegenheid gesteld werd eene meer stellige opgave aan den archivaris van Koloniën te doen van hetgeen ik gaarne zou wenschen te ontvangen; de heer $P$. R. Beukers was mij dan steeds met vriendelijken ijver ter wille. Zoo is het uitgangspunt der verhandelingen, die het tijdschrift van het Instituut gedurende onderscheidene jaren van mij heeft gepubliceerd, steeds geweest de verzameling-Bisschop. Niet dat hiervan bij de samenstelling van alle verhandelingen gebruik kon gemaakt worden, b.v. miet van het Lampong-artikel, maar zij

(a) Zie het verslag van dit onderzoek in de Bijdragen van het Instituut dl. XLII (1897), bl. 183. 
wees mij, van het een op het ander, den weg voor hetgeen mij ontbrak. $\mathrm{Nu}$ ben ik daarmede aan het einde. Voor het raadplegen door anderen van die verzameling is het misschien geriefelijk, dat ik opgeef de verhandelingen, waarin ik stukken er van aanhaalde. Daar echter verscheidene dier opstellen mede moeten aangegeven worden onder de vermelding van de literatuur, waarnaar met verkorting wordt verwezen in deze geschiedenis, zal ik eerst onder dat hoofd bedoelde opgave laten volgen.

Hadden de verschenen artikelen meer een historisch dan rechtstreeks practisch belang, niet alzoo is het met het werk, dat ik hier aanbied. Op dezen stond immers zijn noch de gebeurtenissen, noch de tijden te voorzien, dat het Londensch verdrag van 17 Maart 1824 enkel slechts geschiedkundige waarde zal hebben, gelijk b.v. het daaraan voorafgaand tractaat van 1814. Reeds de bepaling, om geene andere te noemen, van art. 15, volgens welke de voormalige Nederlandsche factorijen in Bengalen, de voormalige Engelsche bezittingen op Sumatra's Westkust, het schiereiland Malakka, Billiton en den Riouw-archipel, bij verlating door eene der partijen, onmiddellijk aan de wederpartij zullen overgaan, waarborgt het tractaat een langen duur. Over de samenstelling van het verdrag denk ik hoogst ongunstig; van Engelsch standpunt heeft men er alles van genomen, wat er van te halen was; maar van Nederlandsche zijde beoordeeld, gevoelt men ook in dit opzicht, dat ons de groote mannen der Republiek waren ontvallen. Ik heb hier niet op het oog de ruilingen, waarover met goed recht verschillend kan worden gedacht; maar wel tal van andere voorschriften, die wij ons niet hadden moeten doen aanleunen, en waarvan men gerustelijk kan beweren, dat weigering onzerzijds op afdoende gronden slechts eerbiedige goedkeuring zou hebben verkregen van de wederpartij. Wat is bijvoorbeeld dat eigen voorschrift van art. 15? Gevoelde men dan onzerzijds niet, dat zulk eene bepaling voor alle tijden alléén ten goede zou kunnen komen van de machtiger partij, die in handen zou krijgen een casus belli, wanneer wij haar niet nakwamen en zichzelve er aan zou kunnen onttrekken onder diplomatieke vormen? Neen, men dacht dat op die wijze Singapore vanzelf ons nog wel eens in den schoot zou vallen! Wat te denken van die an het tractaat gehechte wijdloopige nota's, die dezelfde kracht als het verdrag zouden hebben, en waardoor de met moeite verkregen strenge formuleering der bepalingen dadelijk weder verwaterd werd! Wat omtrent die quaestie van het Engelsche Atjeh- 
verdrag, dat immers bij de Engelschen altijd eene doode letter was geheeten! Wat omtrent dit prijsgeven van Nederlands uitsluitend gezag van Sumatra, waarvan wij later, o. $\mathrm{m}$. in 1842 , de wrange vruchten hebben geplukt, tegelijkertijd dat we het kostbare Malakka afstonden, ten einde dat oppergezag over Sumatra te krijgen!

Zoo ik het niet noodig acht speciaal de instellingen en de personen te noemen, die mij — illusieloozen bedelaar om stof voor de bewerking der historische studiën - ter wille zijn geweest, ik mag hier niet onvermeld laten de vruchten door onze geschiedenis getrokken van de gelegenheid, die de Engelsche regeering schonk om uit haar India Office zoovele stukken te garen, die op het door mij behandelde tijdvak betrekking hebben. Tk kreeg ook daaruit den indruk, dat de geschiedbeschrijving in Nederland, wat waarheidsliefde betreft, zeer hoog staat. Zoover ik mij kan herinneren, hebben die stukken weliswaar meer licht verspreid over hetgeen reeds bekend was, doch slechts om te bevestigen, hetgeen door Nederlandsche publicisten was medegedeeld. Aan de geschiedenis onzer koloniale politiek van den aanvang der $19^{\circ}$ eeuw zal zeker sen nieuwe groote dienst worden bewezen, wanneer nu ook spoedigst ons eigen Ministerie van Koloniën zijn archief uit dat tijdvak, b. v. tot 1848 opruimt, om het naar het vergroote gebouw van 's Rijks archief te doen overgaan.

Over den opzet van de hierbij aangeboden geschiedenis kan men zeker ook niet zonder recht verschillend denken. Gelijk de lezer weet, heb ik in vroegere verhandelingen reeds min of meer aanzienlijke brokstukken ervan opgenomen, zoodat ik er nu slechts kortelijk naar behoef te verwijzen. Zulk eene manier heeft natuurlijk haar bezwaar; nochtans - ik zou het ook zeggen, indien het anders ware - rees mij bij de bewerking dezer verhandeling menigmaal in de gedachte, hoe goed het is geweest, dat ik dien weg volgde, al heeft dit mij veel meer arbeid gekost. Hierdoor toch kwamen de verschillende perioden veel beter tot haar recht; de incidenten, die de onderscheidene onderwerpen schiepen, traden daardoor beter in het licht; de draad van het verhaal in den gang der onderhandelingen zelven kon men aldus onafgebroken volgen, zonder dat het overzicht in eene zee van feiten onderging. Men verlieze daartoe niet uit het oog, dat het tractaat van 1824, op het gebied der diplomatie, een zeer bijzonder stuk, misschien wel een unicum is. Houden toch, over het geheel genomen, staatkundige overeenkomsten een concreet onderwerp in, dat min of meer artikelsgewijze wordt 
uitgewerkt, het verdrag van 1824 handelt over velerlei verschillende zaken, die alle eene eigen geschiedenis hebben.

Gelijk ik dusver steeds deed, doe ik hier nu volgen eene bronnenopgave met vermelding der verkortingen, waaronder ik ze aanhaal; bij enkele werken voeg ik eenige opmerkingen. Het tijdschrift van het Koninklijk Instituut vermeld ik enkel als Bijdragen. De gewone cijfers achter de verhandelingen, zonder voorvoeging, bedoelen de bladzijden.

\section{Literatnur.}

I. Aanwijzing van alle verhandelingen, waarin door mij van de Bisschop-verzameling werd gebruik gemaakt. Voor zoover de verhandelingen niet worden aangehaald in de hierbij aangeboden geschiedenis, geef ik geene verkorting aan.

a. In de Bijdragen:

1. "De zendingen van Ibbetson en Anderson naar Sumatra's Oostkust in 1820 en 1823" dl. XLVII (1897) 210.

Op bl. 217 moet r. 5 v. o. van den tekst achter Europe staan een punt, en alzoo het daarop volgende not een hoofdletter hebben. Op bl. 221, vóór het begin der $1^{\mathrm{e}}$ alinea, staat them: dit moet zijn there.

2. "Fendall's en Raffles' opvattingen in het algemeen omtrent het Londensch tractaat van 13 Augustus 1814" dl. XLVII (1897) 341: Opvattingen. - Zie 342 (ov. 2) de eerste alinea. - Op bl. 414 (ov. 74), r. 15 v. o. staat Gezant lees Minister van Buitenlandsche Zaken en r. 12 v. o. stel vóór Fagel: "Van Nagell aan".

3. "Het afbreken van onze betrekkingen met Bandjermasin onder Daendels en de herstelling van het Nederlandsch gezag aldaar

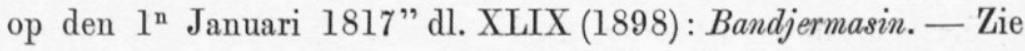
de slotalinea op bl. 31 , met de fout "sub $77 "$ in plaats van bl. $73-74$.

4. "Sumatra's Westkust naar aanleiding van het Londensch tractaat van 13 Augustus 1814" dl. XCIX (1898) 205: Sumatra's Westkust II.

5. "De Singapoorsche papieroorlog" dl. XLIX (1898) 389 : Singapore I.

De stippels, aangegeven in noot $a$ op bl. 450 (ov. 61), te vervangen door het woord reply, en die in noot $b$ aldaar door: nor are now necessary to be introduced into; die, aangegeven in 
noot $a$ op bl. 451 (ov. 63 ), door: schemes. - Op bl. 463 (ov. 75 ) r. 2 v. b. niet het jaartal 1829 , maar 1819 . - Op bl. 544 (ov. 156) in noot 69 niet 21 Augustus, maar 20 Augustus en niet bl. 286 , maar bl. 285 . - Op bl. 546 (ov. 158), de voorlaatste regel van den tekst, staat Chonk m. z. Chank. - Op bl. 547 (ov. 159) in de voorlaatste alinea moet de regel vernment of Madras) in which the Dutch claim a participa - verhuizen onder aan den tekst op de vorige bladzijde.

6. "De teruggave der Nederlandsche factorijen in Hindostan krachtens het Londensch tractaat van 13 Augustus 1814" dl. L (1899) 247: Factorijen I.

De bijl. 3 wordt gezegd te zijn "van Dowdeswell"; lees: van den Vice-President in Rade te Calcutta.

7. "De commissiën van den schout-bij-nacht C. J. Wolterbeek naar Malakka en Riouw in Juli-December 1818 en Februari-April 1820" dl. LI (1900) 1: Malakka-Rionw. Zie van bijl. 9 af. Men zie ook de aanvulling en verbeteringen in de voorrede der onder 9 volgende Palembang-verhandeling, bl. IV-VI.

8. "Raffles' Atjeh-overeenkomst van 1819" dl. LI (1900) 159: Atjeh. Verbeteringen in de voorrede der hieronder volgende Palembang-verhandeling bl. VI-VIII.

9. "Palembang en Banka in 1816-1820" dl. LI (1900) 331: Palembang.

Men zie bijl. 27, 36, 38 en bl. 504 (ov. 174).

10. "Raffles' betrekkingen met Nias in 1820-1821" dl. LII(1901) 584 .

11. "De Nederlandsche Factorijen in Vóór-Indië in den aanvang der $19^{\mathrm{e}}$ eeuw" dl. LIII (1901) 285 : Factorïen II. — Zie bijl. 10.

12. "De stichting van Singapore, de afstand er van met Malakka door Nederland en de Britsche aanspraken op den Linga-Riouw Archipel" dl. LIV (1902) 313: Singapore II. - Zie de slotalinea op bl. 314 (ov. 2).

13. "Benkoelen krachtens het Londensch tractaat van 17 Maart 1824" dl. LV (1903) 283: Benkoelen.

14. "Brieven van den Gouverneur-Generaal van der Capellen over Dipanegara's opstand" dl. XLVI (1896). Zie bl. 558 (ov. 24).

b. Verder:

15. "Eene herinnering aan den zeerooversaanval op de Seaflower in 1822": Tijdschrift voor Nederlandsch-Indië van 1902: Seaflower. 16. Deze geschiedenis. Zie bijl. 2, 8, 24 . 
II. Aanwijzing van de verkortingen, waaronder ik in deze geschiedenis de volgende werken aanhaal:

1. Smulders: "Geschiedenis en verklaring van het tractaat van 17 Maart 1824." door C. M. Smulders (1856). - Destijds eene gelukkige gedachte dit onderwerp als proefschrift te nemen; het is nu eene halve eeuw lang het eenige werk geweest, dat een stelselmatig verhaal over de onderhandelingen bevatte. Uitnemend ook als proefschrift, draagt het er mede de zwakheden van. Terecht noemde E. de Waal op bl. 78 noot 1 van zijn Nederlandsch-Indie in de Staten-Generaal (1860) het slechts eene "handleiding" voor die geschiedenis, "die echter nog veel vergelijking met de echte bescheiden vereischt". De grondigheid der behandeling laat te wenschen over en positieve fouten, lang niet van belang ontbloot, komen er in voor, gelijk uit noten van mijn arbeid blijken zal.

2. Opvattingen:

3. Bandjermasin:

4. Sumatra's Westkust II (a):

5. Singapore I:

6. Factorijen I:

7. Malakka-Riouw:

8. Atjeh:

9. Palembang:

Zie onder de overeenkomstige nommers hiervoren.

10. Hoek: "Het herstel van het Nederlandsch gezag over Java en onderhoorigheden" door Mr. I. H. J. Hoek (1862).

11. Factorijen II: ) Zie onder de overeenkomstige nommers hier-

12. Singapore II:

13. Benkoelen: Y voren.

14. Norman: "De Britsche heerschappij over Java en onderhoorigheden (1811-1816)" door Mr. H. D. Levyssohn Norman (1857).

15. Seaflower: Zie onder het overeenkomstige nommer hiervoren.

16. Falck's Brieven: "Brieven van A. R. Falck" (1861).

Dit is de tweede uitgave; eene eerste verscheen in 1857. Ze werd bezorgd door Falck's bloedverwant $0 . W$. Hora Siccama, denzelfden, die in 1823 als "amanuensis" der gevolmachtigden, minister Falck naar Londen vergezelde: zie hoofdstuk XI. De beoefenaar der koloniale geschiedenis heeft over het weinige, dat dit werk ten aanzien van de koloniën bevat, reeds zijne

(a) Sumatra's Westkust I onder No 24. 
teleurstelling nitgesproken, immers waar de heer De Waal op bl. 77 dl. I van zijn "Nederlandsch-Indië in de Staten-Generaal" opmerkt: "Wetende dat Falck zes jaren aan het hoofd van het koloniaal Departement stond, verwacht men welligt veel over de koloniën te vinden in Hora Siccama, Brieven van A. R. Falck, 1795-1843 ('s Hage, Nijhoff 1857). Daarin zijn wij teleurgesteld. Behalve een paar aanhalingen elders in onze noten, ontmoetten wij er in wezenlijkheid niets waarop voor de studie van koloniale aangelegenheden de aandacht zou gevestigd kunnen worden."

17. Falck's Ambtsbrieven: "Ambtsbrieven van A. R. Falck 18021842" (1878). - Opmerkingen over deze beide uitgaven volgen nog op verschillende plaatsen van dit werk, om te beginnen, onder het volgende nommer.

18. B $\ddot{j} d r$. E. : "Bijdragen tot de geschiedenis der onderhandelingen met Engeland, betreffende de overzeesche bezittingen, 18201824. Getrokken uit de nagelaten papieren van wijlen den minister van Staat Elout, enz." (1863).

Dergelijke uitgaven, als wij ook hadden onder 16 en 17, zouden zeer in waarde gewonnen hebben, wanneer daaraan toelichtende opmerkingen hadden toegevoegd kunnen worden. Kenschetsend is de opneming van een briefje op bl. 66, waarin niets anders staat, dan dat Van Nagell aan Elout vraagt: Kom eens hier, ik kan u iets zonderlings laten lezen! - Wat bedoeld wordt, zal ik in hoofdstuk V mededeelen. - Zulke uitgaven vinden echter menigmaal geen uitgebreiden lezerskring, omdat ze dikwerf meer voor bronnen dienen ten behoeve van den geschiedschrijver dan voor aangename lezing; daarom moet men zich soms wel wat beperken en kan dit ter verschooning strekken. van het weglaten van stukken, die men er ongaarne in mist als bijvoorbeeld de Additioneele instructie van 1823, als eene belangrijke depêche over de Geldelijke geschillen, zooals nader zal worden opgemerkt. Maar waarom dan in de $B \ddot{j} d r$. $E$. stukken opgenomen, die reeds in Falck's Brieven waren afgedrukt, als de in deze vitgave voorkomende epistels, $\mathrm{N}^{\text {os }} 139,145$, 159, welke men terugvindt in Bijdr. E. bl. 161, 218, 254 . Eerstgenoemde brief werd afgedrukt met verschillenden datum: welke is nu de juiste? Doch dit daargelaten, het dubbel gedrukt schrijven handelt over de vraag of men het afschrift van een particulieren brief van gouverneur-generaal baron van der 
Capellen aan gouverneur-generaal markies Hastings (lord Moira) zal laten lezen aan Canning, een brief, waarin o. a. wordt opgekomen tegen eene ongunstige beoordeeling over Elout. Het gewicht dat men er aan hecht, ook blijkens de daarmede verband houdende brieven in $B \ddot{j} d r$. E. bl. $157 \mathrm{vv}$, , moest dan toch de vraag doen rijzen, waarover men het eigenlijk had, en eene vraag die zoo gemakkelijk met een nootje viel te beantwoorden, wijl het particulier schrijven reeds was gepubliceerd door de in 1852 verschenen Notice van De Grovestins, bl. 481. - En de bezorger van de Falck-stukken, die de campagne der onderhandelingen van 1823-1824 had medegemaakt, er van afziende om in de correspondentie, wat dieper te grijpen? - 't Is echter ook waar, dat dergelijke uitgaven, al worden ze min volledig samengesteld, belangrijke stof leveren voor de authentieke geschiedbeschrijving.

19. Bijdr. E. 1851: "Bijdragen tot de kennis van het koloniaal beheer, getrokken uit de nagelaten papieren van wijlen den minister van Staat Elout" (1851).

20. Elout: "Mr. C. T. Elout als commissaris-generaal in NederlandschIndië", in de Juli-aflevering 1898 van De Tijdspiegel bl. 229.

21. Fagel's Ontslag: "Hendrik Fagel's ontslag uit den staatsdienst in 1823", in De Tijdspiegel van April 1899 bl. 393.

22. Sluiting: "De sluiting van het Londensch tractaat van 13 Augustus 1814" in de Bijdragen, dl. XLVII (1897) 239.

23. Lampongs: "Raffles' bezetting van de Lampongs in 1818" in de Bijdragen, dl. L (1899) 1.

24. Sumatra's Westkust I: "Eene bijdrage tot E. B. Kielstra's Opstellen over "Sumatra's Westkust" in de Bijdragen, dl. XLIV (1894) 257.

De stukken 20-24, zijn van mijne hand.

25. Brieven-Hogendorp: "Brieven en Gedenkschriften van Gijsbert Karel van Hogendorp". Het $\mathrm{V}^{\mathrm{e}}$ deel en de volgende deelen verschenen na mijne verhandeling over het tractaat van 1814 . Intusschen blijkt zeer belangrijk, wat ze over de terugverkrijging der koloniën bevatten, speciaal het $\mathrm{V}^{\mathrm{e}}$. Uit het labyrinth dier stukken de koloniale beschouwingen te trekken, voor zoover ze althans binnen de lijst van mijn arbeid konden gebracht worden, scheen mij uit dien hoofde gewenscht; vandaar dat in den aanvang vooral Van Hogendorp aan het woord wordt gelaten. 
26. Corr.: Het IV ${ }^{e}$ deel der "Correspondence, Despatches, and other Papers, of Viscount Castlereagh, second Marquess of Londonderry. Edited by his brother Charles William Vane, Marquess of Londonderry. Third series. Military and Diplomatic. In four volumes." (1853).

In dezen arbeid zal ik onderscheidene brieven uit dat werk doen overdrukken, en wel omdat het in Nederland niet onder ieders bereik is; zelfs in voorname bibliotheken wordt het soms gemist. Men lette op eene fout, die in dl. IV voorkomt en den lezer licht op een dwaalspoor zou kunnen brengen. De op .bl. 147 en 176 voorkomende brieven van Hendrik Fagel, onzen ambassadeur te Londen, zijn ten onrechte afgedrukt met de onderteekening R(obert) Fagel, diens broeder en gezant te Parijs. Deze was gedurende de ellendige Napoleontische tijden adjudant geweest van den lateren koning Willem I, o. a. toen de vorst, als Erfprins van Oranje, den slag bij Jena dd. 14 October 1806 medemaakte, waar beiden werden gevangen genomen door de Fransche overwinnaars (a).

27. Parvé: "Handelingen van Sir James Brooke op Borneo" door D. C. Steijn Parvé (1859).

28. Lauts: "Geschiedenis van de vestiging, uitbreiding, bloei en

(a) „Abends nach Potsdam zurück gekehrt, erfuhr ich, dasz der Prinz von Oranien daselbst als (auf Ehrenwort entlassener) französischer Kriegsgefangener eingetroffen sei. Statt über das traurige Geschick Preuszens und seinen eigenen Person zu klagen, ist dieser Prinz unmittelbar nach seinem Eintreffen in die Wohnung seiner Geliebten, einer Ballettänzerin, gelaufen. Diese hatte indessen, , aus Patriotismus', oder, weil sie sich für dem Hofe angehörig hielt, Berlin verlassen und sich nach Küstrin begeben. Der Prinz ist auszer sich gerathen and hat der Mutter so heftige Vorwürfe gemacht, dasz diese ihren Sohn nach Wiedereinholung der schönen Flüchtigen aussandte." Ad. 22 October 1806, uit het dagboek van graaf François Gabriel de Bray. Bl. 242 "Aus dem Leben eines Diplomaten alter Schule" (1901). "Der Kaiser fährt fort, das Land mit groszer Härte zu behandeln - gefangene Generale und Offiziere werden täglich hierher geführt; heute sind die Generale Tauentzien und Fagel, der Adjudant des Prinzen von Oranien, eingetroffen." Ad. 31 October 1806 uit het dagboek, bl. 242. - Het leven van den prins van Oranje met eene maitres, terwijl hij gehuwd was met eene zuster van den koning van Pruisen, was eene der oorzaken van de verwijdering tusschen beide vorsten. Dit staat te lezen in Brieven-Hogendorp V, bl. 62: „Robert Fagel verhaalde mij al in 1808", teekent Hogendorp verder daar aan over den toenmaligen Erfprins, „dat hij den koning (van Pruisen), sedert dezelve aan de regering gekomen was, niet meer als zijn zwager behandelde, maar met den hoed in de hand." 
verval van de magt der Nederlanders in Indië" door G. Lauts.

De hoogleeraar gaf in 1837 ook uit een "Onderzoek naar geest en strekking van het tractaat van den $17^{\mathrm{n}}$ Maart 1824". Deze verdienstelijke beschouwingen blijven van waarde, doch ik heb het niet noodig gevonden er gebruik van te maken voor dezen arbeid.

29. Rochussen: "Verdediging der regten van Nederland tegen de aanmatigingen van Groot-Brittanien, met betrekking tot het tractaat op den $17^{\mathrm{n}}$ Maart 1824, tusschen de beide Rijken gesloten" door J. J. Rochussen (2e druk 1836).

30. De Sturler: "Het grondgebied van Nederlandsch Oost-Indië in verband met de tractaten met Spanje, Engeland en Portugal". Academisch proefschrift van J. E. de Sturler (1881).

31. Kemper: "Letterkundige aanteekeningen betreffende de geschiedenis van het Nederlandsche staatsleven en staatsregt" (1871) van Jhr. Mr. J. de Bosch Kemper.

32. Van de Graaff: Brieven van en aan Mr. H. J. van de Graaff 1816-1826". Bezorgd in 1901 door mij. Verschenen in twee stukken der Verhandelingen van het Bataviaasch Genootschap van Kunsten en Wetenschappen, dl. LII, met een belangrijk vervolg. Hun, wien ik het genoegen deed met een exemplaar van het te 's-Gravenhage onder mijne leiding gedrukte werk aan te bieden, zij medegedeeld, dat ik buiten staat werd gesteld ook het vervolg te zenden, daar deze uitgave van het Genootschap in 1902 te Batavia werd gedrukt en men hierin reden schijnt gevonden te hebben mij geene geschenk-exemplaren te doen geworden.

33. Notice: "Notice et souvenirs biographiques du comte Van der Duyn de Maasdam et du baron de Capellen, Recueillis, mis en ordre et publiés par leur ami le B ${ }^{\text {on }}$ C. F. Sirtema de Grovestins" (1852).

34. Walpole: "A history of England from the conclusion of the great war in 1815 by Spencer Walpole" (1878). In twee deelen, en een bijzonder fraai werk; o. a. ook eene zeer goede school voor hen, die roeping gevoelen tot het schrijven van gedenkboeken bij regeeringsjubelfeesten. Wat eene onsamenhangende, onvolledige, vervelende rhapsodie ziet men niet vaak bij dergelijke gelegenheid aan den dag treden: 't is om van het vooruitzicht te rillen bij elk nieuw jubelfeest.

35. Martineau: Het $1^{\mathrm{e}}$ deel, handelende over 1816-1824: (1877) 
van het mede bijzonder aantrekkelijke werk "A history of the thirty years peace A. D. 1816-1846 by Harriet Martineau". In 4 deelen.

36. Greville: De $4^{\mathrm{e}}$ druk van het eerste deel (1875) van "The Greville Memoirs. A journal of King George IV and King William IV by the late Charles C. F. Greville, Esq., clerk of the council to those sovereigns." In 3 deelen.

37. Characters: Het $2^{\mathrm{e}}$ deel (1868), waarin de verhandeling over "Canning, The brilliant man", der "Historical characters" van Sir Henry Lytton Bulwer. In twee deelen.

38. Wilson: Het $2^{\text {e }}$ deel (1848) van "The history of British India 1805-1835" door Horace Hayman Wilson.

39. Speeches-Canning: "The speeches of the Right Honourable George Canning with a memory of his life" door R. Therry in 6 deelen (1828).

40. Richelieu: "Le duc de Richelieu, son action aux conférences d'Aix-la-Chapelle, sa retraite du pouvoir" door Raoul de Cisternes (1898).

41. Utrechtsche Bïdragen: Het tijdschrift "Bijdragen tot de kennis der Nederlandsche en vreemde koloniën, bijzonder betrekkelijk de vrijlating der slaven. 1845. (1846).

42. Juste: Het $1^{\mathrm{e}}$ deel (1872) van "La révolution Belge de 1830" door Théodore Juste.

Ten slotte zij herinnerd aan de verkortingen:

B. : Bisschop-stukken.

B. Z. : Stukken van Buitenlandsche Zaken. 


\section{De stratslieden der Londensehe koloniale tractaten van 1814 en 1824 .}

De lijdensgeschiedenis van het tractaat van 13 Augustus 1814 tot ze onderging in het tractaat, waarvan het ontstaan in dezen arbeid zal beschreven worden, voert ons telkens terug tot de namen van Nederlandsche en Britsche staatslieden, die wij voor een juist overzicht in herinnering behooren te houden.

$A$. $R$. Falck, met den titel van secretaris van Staat, oorspronkelijk directeur van het kabinet van den Souvereinen Vorst, later in 1818 minister van Koloniën. In 1808 fungeerde hij reeds als commissaris-generaal voor de Koloniën, later als secretaris-generaal bij het ministerie van dien naam, zonder sporen achter te laten, dat hij er veel bij heeft opgenomen (a).

Bij de wedergeboorte van den Nederlandschen staat was Gijsbert Karel van Hogendorp minister van Buitenlandsche Zaken (b). Weinige maanden later verwisselde hij het ambt met dat van vice-president van den Raad van State (c). Den $9^{\mathrm{n}}$ April 1814 toch den Britschen minister Castlereagh schrijvende, gelijk ik nader zal mededeelen, besloot hij dien brief aldus (d):

"Aprés avoir touché de si grands intérêts, s'il est permis de dire un mot de ma personne, j'ai l'honneur d'informer V. E. que S. A. R. m'a nommé Secrétaire d'État, Vice-Président de son Conseil d'État, ce qui me met en relation avec tous les Ministres. Celui que j'avois est donné au Baron de Nagell, ci-devant Envoyé de Hollande à Londres, et aussi distingué par ses lumières que par ses talens. J'apporte dans ma nouvelle place tout le zéle, que j'ai déployé dans le premier."

Wij zullen in het volgende hoofdstuk zien, welken invloed Van

(a) Zie over hem nader Sluiting, 250, ov. 12; en Fagel's Ontslag 406, ov. 14; vooral echter ook Brieven-Hogendorp V, 44.

(b) Brieven-Hogendorp V, 43, 46.

(c) Brieven-Hogendorp V, 68.

(d) Brieven-Hogendorp, V, 459-460. 
Hogendorp op het tractaat van 1814 gehad heeft. Hier slechts een paar korte aanteekeningen. Bij de verdrijving der Franschen uit Duitschland had Dirk van Hogendorp zijn post als gouverneur van Hamburg verloren. Gijsbert zag in dien broeder nog eene waardevolle kracht voor onze terug te erlangen koloniën. "Ik neem de vrijheid om te herhaalen", schreef hij den Souvereinen Vorst dd. 6 Maart 1814 (a), "dat er partij zou te trekken zijn van den gedestitueerden Gouverneur van Hamburg". - "Ik heb", bericht hij andermaal den Vorst dd. 19 Juni 1814, "aan mijnen broeder vier kapitale vraagen omtrent de Oost-Indische bezittingen voorgelegd" en die vragen worden dan achtereenvolgens beantwoord. "Onder het handelen over de bezittingen, die gemist kunnen worden", luidt in verband hiermede Gijsbert's bericht aan den Vorst dd. 27 Juni 1814, "is het mij toegeschenen, dat het voor den Ambassadeur Fagel nuttig zoude zijn een korte en zakelijke beschrijving te hebben van iedere Bezitting. Ik heb deeze beschrijvingen aan mijn broeder gevraagd, als een nadere uitlegging van zijn antwoord op mijn eerste vraag, en leg dezelve over of zij tot het bovengemeld einde zouden kunnen dienen. Nog meer bijzonderheeden kan de schrijver altijd geeven, al ware het, dat UKH. hem naar Londen wilde zenden" (b). - Doch men lustte Dirk van Hogendorp niet; de Nederlandsche regeering stond hem evenwel een pensioen toe; hij loonde dit met den betreurenswaardigen stap van zijn overgang naar Napoleon, op het vernemen van diens terugkomst uit Elba.

Nog moge hier aangeteekend worden, dat Gijsbert Karel hoog wegliep met Daendels. Breedvoerig licht hij bij schrijven dd. 6 September 1814 den Souvereinen Vorst over hem in (c): "al was het alles waar", merkt hij o. a. op, naar aanleiding van het ongunstige, dat van hem verteld werd, "zoo neemt het niets weg van zijne politieke verdiensten, en al had de Mensch het slecht gemaakt, de Gouverneur-Generaal heeft wel voldaan." Ook in eene nota van 8 Augustus te voren had Van Hogendorp de benoeming van Daendels tot landvoogd op den voorgrond gesteld, den Vorst over de Oost-Indische bezittingen schrijvende (d): "Zij hebben langen tijd gekwijnd onder de Compagnie; de Commissie van Nederburgh heeft niet veel verandering aangebracht; Daendels

(a) Brieven-Hogendorp V, 325.

(b) Brieven-Hogendorp V, 397-398.

(c) Brieven-Hogendorp V, 412-414.

(d) Brieven-Hogendorp V, 409-410. 
heeft er een Revolutie gemaakt, zo veel ik zien kan, tot nut van het Algemeen, dog niet zonder geweld aan individuus. De Engelschen schijnen de revolutie van Daendels voltooid, misschien boven de maate uitgebreid te hebben. In welk een staat moet zig de talrijke Inlander bevinden (a), na al wat hij in dertig jaren heeft zien gebeuren? Om die moreele kragt te herstellen en te bewaaren, door welke wij op zulk een afstand met een geringe magt geheerscht hebben, is er een Gouverneur noodig, die het land, de natie, de taal, de vooroordeelen kent. Tot heden toe hebben wij nooit een goede partij van dat Land getrokken, en Daendels, die begonnen had, erkent wiens beginselen hij ingevoerd heeft. Om dan de klem der Regeering te herneemen, om partij van het Land te trekken, weet ik niemand aan UKH. te noemen, die eenigzins bij mijn broeder komt, en ik agte mij verpligt hem dit getuigenis te geeven, omdat het algemeen welzijn en de dienst van UKH. er mede gemengd zijn. Naast aan de plaats van Gouverneur, indien er polityke redenen tegen waren, zoude hij zeer geschikt zijn tot Commissaris Gl. om een vast stelsel van Regeering in te voeren.

"Heb ik mij niet te veel vermeeten met vrijmoedig te zeggen wien $i k$ geschikt oordeele, zo vraag ik dezelfde verschooning, wanneer ik er iets bijvoege omtrent iemand, die mij ongeschikt voorkomt en die naar mijn oordeel alles in de war zou stuuren. Ik erken de verdiensten van den Generaal Janssens in de administratie van Oorlog; ik heb hem leeren kennen als een zwak Gouverneur van eene Kolonie(b), die de orders van zijn Gouvernement niet durft ten uitvoer te brengen, en die zig door alle de partijen heen en weer laat slingeren. Daarbij komt, dat hij totaal geslagen zijnde op Java, weinig aanzien bij den Inlander genieten kan. UKH. zal zig niet herinneren, dat ik ooit den $\mathrm{G}^{\mathrm{l}}$ Janssens benadeeld heb, ofschoon hij mij door zijn zwakheid de grootste schade heeft toegebragt. Voor mijzelven kan ik vergeeven; als het aankomt op den dienst en het publijk welzijn ontzie ik niets. Ik wensch hartelijk, dat onze kostbare bezittingen welrasch onder het Bestuur van UKH. mogen bloeien."

De onbevooroordeelde wijze, waarop Van Hogendorp Daendels wist te waardeeren, doet den schrijver eer aan; dat ook velen in Indië, "meest zeer goede koppen", den geweldigen landvoogd van voorheen vereerden, deelde ik elders mede (c); maar voor zulk eene

(a) Zoo staat het er.

(b) De Kaap de Goede Hoop tijdens de kolonisatieplannen van G. K.

(c) Zie Van de Graaff I, 25 . 
vrije opvatting in het belang der zaken ten opzichte van den Franschen maarschalk was in den Oranje-kring van dien tijd geene plaats. Gelijk de lezer weet, werd baron Van der Capellen tot landvoogd benoemd, die niets van de koloniën wist, merkt Van Hogendorp op: men zou het zich eerlang berouwen; en als Commissaris-Generaal werd met hem benoemd de heer Elout, door Van Hogendorp tot vele posten bekwaam geoordeeld (a), die echter ook geene plaatselijke ondervínding had, benevens Muntinghe, die daarentegen wel degelijk op de hoogte was, doch weder op verlangen van Elout geschrapt werd, omdat de Commissie-Generaal papier blanc zou zijn (b). Overigens, met alle waardeering van. het doorzicht van Gijsbert Karel, de koloniale regeering in handen te leggen van mannen als Daendels en Dirk van Hogendorp, hen ook te belasten met de overneming der koloniën, het verbaast mij wel, dat Gijsbert Karel tegen dit waagstuk zoo weinig bezwaar had. Maar ook kan men haast als zeker zeggen, dat onder deze mannen de Singaporegeschiedenis een anderen loop zou hebben genomen.

Tot chef van het departement van Koloniën werd, echter niet met den titel van minister, benoemd Goldberg. "Ik heb gedurig gedacht", stond in eene nota dd. 6 September 1814 van Van Hogendorp aan den Souvereinen Vorst(c), „om een bekwaam persoon aan UKH. voor te dragen, ten einde als Secretaris van Staat voor de Colonien te fungeeren in de afwezigheid van de Heeren van der Capellen en Falck, doch onder den blooten titel van Directeur-Generaal en ondergeschikt aan den Heer van der Hoop. Thans komt mij zulk een provisioneele aanstelling hoogst wenschelijk voor, en na de ondervinding, die ik sedert eenigen tijd heb van de heldere denkbeelden en de verkregen kundigheden ook in deze zaak van den Heer Goldberg, weet ik geen beter, ja zelfs geen ander UKH. voor te dragen." Met deze voordracht ging de Vorst te liever mede, wijl Goldberg diensten aan het huis van Oranje tijdens de ballingschap had bewezen. Als chef van het departement van Koloniën heeft hij echter niet uitgeblonken; zijne verwarde denkbeelden over muntwezen zijn inzonderheid voor de koloniën noodlottig geweest (d); in 1818 werd hij door Falck, met den titel van minister, vervangen.

(a) Briven-Hogendorp V, 231.

(b) Zie o. a. Van de Graaff I, 51.

(c) Brieven-Hogendorp V, 414. - Van der Capellen was te Brussel als gouverneur-generaal der zuidelijke provinciën.

(d) Zie mijne verhandeling over De Nederlandsche standpenning van 1817 in $7^{\text {e }}$ Volg. II. 
Het ministerie van Buitenlandsche Zaken werd, na de kortstondige vervulling door Van Hogendorp, opgedragen, gelijk ik mededeelde, aan den heer A. W. C. van Nagell tot Ampsen, "een groot heer uit Gelderland", naar Elout's uitdrukking (a). Door hem waren onder de Republiek de functiën van gezant te Londen vervuld en bestond er dientengevolge, evenals bij Falck, wel aanleiding, om de koloniale quaestiën ter harte te nemen; de ondervinding zou evenwel aantoonen, dat ook hij er geen gelukkig zicht op had (b). Na Nederlands wedergeboorte, was Van Nagell vier maanden lang op zijn buiten in Gelderland gebleven "als iemand, die zien wilde waar het naartoe liep", schrijft Van Hogendorp. In Maart 1814 kwam hij te 's-Gravenhage, waar hij Van Hogendorp op een diner bij de Prinses-Moeder ontmoette. "Zijne vriendelijkheid voor mij was groot", memoreert Van Hogendorp, "en is het lang gebleven." Men had een president noodig voor de Notabelen, die over de Constitutie van den nieuwen staat zouden beslissen; Elout vestigde op Van Nagell de aandacht. Toen deze Van Hogendorp bezocht, polste Gijstbert Karel zijn bezoeker, die zich er toe genegen verklaarde, "mits beleefdelijk verzogt", was de geheel Van Nagellsche voorwaarde. "Ik ben altijd te rond in zulke zaken geweest", merkt Van Hogendorp naar aanleiding hiervan op (c), " om veel te weten van de wijze, op welke dezelve gemeenlijk behandeld worden. Het bleek egter, dat ik deze niet kwalijk aangevat had, alzoo de Heer van Nagell zig niet alleen dit Presidie liet welgevallen, maar ook vervolgens het Portefeuille van Buitenlandsche Zaken aannam (d). Hij verzogt mij om onderrigt van den staat van zaken, en bedankte mij voor de edelmoedige wijze van hem dit te hebben gegeven. De Prins zeide mij: het zal wel met $\mathrm{u}$ beide gaan, want in 1787 heb je al te samen gewerkt. In den begin kwam hij mij om mijne gedagten vragen, en op míjn verzoek gaf hij mij eens 's weeks alle de ontvangen brieven te lezen. Het eerste ging allengs over, het tweede heeft voortgeduurd tot mijn ontslag toe."

Hoezeer ten slotte Van Nagell voor Van Hogendorp tegenviel, blijkt uit de aanteekening, die ik nog hier laat volgen (e):

het Tijdschrift voor Nederlandsch-Indië, aflevering Maart 1897, bl. 228 vv., met bijzonderheden over Goldberg's verleden op bl. 230 .

(a) Brieven-Hogendorp V, 68.

(b) Zie over hem nader Sluiting, 250, ov. 12 en Fagel's Ontslag 397-402, ov. $5-10$.

(c) Brieven-Hogendorp V, 68-69.

(d) Zie hierover ook Brieven-Hogendorp V, 356-357.

(e) Brieven-Hogendorp V, 70-71. 
"De vijandschap van den Heer van Nagell voor den Koophandel zit in zijn bloed, en daar hij zeer driftig is, en zig geheel niet meidt voor zijn onderhoorigen, werd dit aanstonds bekend, en trof des te meer, naar mate ik vriend van den Koophandel geweest was. Onze betrekkingen buiten 's lands zijn, naar mijn oordeel, hoofdzakelijk mercantiel, en dit straalt door in de instructie van den Minister. De staatkunde van Europa bestaat egter op zigzelve, en daarom had ik ze afgescheiden. Maar ons aandeel in de politiek dient te strekken ter bevordering van onzen handel. Dit verband moet wonen in het hoofd van den Minister, die het werk der beide afdeelingen onder zijne ogen heeft. Koophandel en Kolonien waren aanvankelijk geen byzonder Departement, maar ik advyseerde op die zaken met den Heer Canneman. De Prins begeerde zulk een Departement op te rigten en mijne gedagten daaromtrent te weten. De Raad van Koophandel en Kolonien werd opgerigt, doch de Directeur-Generaal eerst later benoemd. Ik zag er vooral de noodzakelijkheid van in, toen wij de kolonien terug kregen, en de schikkingen inzonderheid voor Oost-Indië gemaakt werden. Dit gebeurde in den nazomer 1814, terwijl de Prins te Brussel was, hetwelk nog meer verwarring veroorzaakte. Toen drong ik aan op die aanstelling, ten einde alles onder één hoofd te brengen, te meer daar de Prins eerst Falck had doen voorzitten in den Raad van Koophandel en nu van der Hoop daartoe benoemde, die er voor uitkwam, dat hij zig weinig met zulk een voorbijgaande bezigheid wilde ophouden. Falck gaf mij te kennen, dat hij mij daartoe voorgedragen had. Mijn keus viel bepaaldelijk op Goldberg, omdat ik zeker was van zijne koloniale beginselen. Goldberg heeft zig bij Nagell weten bemind te maken door zijne menschenkennis, en zo zijn de zaken van koophandel meestal in zijne handen gevallen. Zij gaan daardoor iets beter dan ik verwagten kon; maar nogthans is het Gode geklaagd, dat ons voornaamste nationaal belang zo verwaarloosd wordt."

Als Nederlandsch ambassadeur te Londen trad op Hendrik Fagel. Zijn vader François Fagel overleed in 1773, toen Hendrik vijf jaar oud was. Hierdoor kwam deze onder de leiding van den grootvader en naamgenoot, de good old Greffier van prins Willem V. In de Fagel's was het griffierschap bij Hunne Hoogmogenden als het ware erfelijk, en zij hebben dat ambt steeds met eere bekleed; toen het 100 jaren in de familie was geweest, gaf de good old Greffier een groot feest; bij diens overlijden in 1790 werd hij door zijn kleinzoon 
opgevolgd (a). In dit ambt had de latere ambassadeur nog medegewerkt aan het ontwerpen van een handelstractaat, waarin ook werden behandeld de aan onze Factorijen in Vóór-Indië behoorende voorrechten, die nochtans in 1814 geheel en al over het hoofd gezien werden (b).

Wij behooren nu ook met eenige Engelsche staatslieden kennis te maken. De chef van het Britsche ministerie was sinds 1812 graaf Liverpool, minister van Financiën. Binnenlandsche Zaken was toevertrouwd aan viscount Sidmouth; Koloniën aan earl Bathurst. Over dezen laatsten minister, dien wij mede reeds bij het tractaat van 1814 leerden kennen, schreef lord Rosebery in 1900: "He himself was one of those strange children of our political system who fill the most dazzling offices with the most complete obscurity. He had presided over the Foreign Office. He was for a term of fifteen years, a Secretary of State. Yet even our most microscopic Biographical Dictionary may be searched in vain for more than a dry recital of the offices that he filled, the date of his birth, and the date of his death."

De man, die aan het ministerie karakter gaf, was Robert Stewart, meer bekend als lord Castlereagh, minister van Buitenlandsche Zaken (c). Bij de vorming van het ministerie was tevens gedacht aan lord Canning. Voor Castlereagh en Canning, die zoo dikwerf in deze verhandeling genoemd zullen worden, was wel aanleiding tot blijvende samenwerking geweest. Zij waren beide Ieren; uit hetzelfde landschap Londonderry; dezelfde partij destijds toegedaan, namelijk die der Tories; gezamenlijk bestrijders der anti-catholieke richting; ongeveer van denzelfden leeftijd, de eene geboren in 1769 , de andere een jaar later, en ongeveer denzelfden leeftijd behalende, de eene overlijdende in 1822, de andere in 1827. Op staatkundig terrein achtte men beide mannen buitengewoon hoog te staan; doch voor

(a) Ziehier de opvolging:

Gaspar 1670-1672;

Hendrik, halve broeder van zijn voorganger, 1672-1690;

Fransois, zoon van zijn voorganger, 1690-1744;

Hendrik, neef van zijn voorganger, 1744-1790: "the good old Greffier";

Hendrik, kleinzoon van zijn voorganger, 1790-1795, de latere ambassadeur te Londen onder koning Willem I.

(b) Zie nader Sluiting 250, ov. 12; Factorïjen II 342, ov. 58; Fagel's Ontslag $402-404$, ov. 10-12; aldaar op eerstgenoemde bladzijde de foutieve mededeeling, dat de Ambassadeur de zoon was van den ouden Griffier.

(c) ${ }_{n}$ The leader of the ministerial phalanx is Robert Stewart, Lord Castlereagh": Martineau 19. 
hen scheen in denzelfden kring van werkzaamheden geene ruimte genoeg; zoo niet altijd geslagen vijanden, stonden zij toch in den regel op een afstand van elkander. Castlereagh, trotsch op zijne voorname geboorte, zijne aanzienlijke betrekkingen, zag neder op den zoon eener vrouw, die op de planken haar onderhoud had verdiend. Canning, buitengewoon door zijne macht over het woord, haalde de schouders op voor den erbarmelijken parlementairen redenaar. Beiden hadden in 1807 deel van het ministerie uitgemaakt: Castlereagh voor Oorlog en Koloniën, Canning voor Buitenlandsche Zaken. Sinds was door den eerste de zoo jammerlijk mislukte expeditie naar Walcheren tegen de Fransch-Nederlandsche troepen georganiseerd. De reeds smeulende verdeeldheid brak dientengevolge los. Den $21^{\mathrm{n}}$ December 1809 duelleerden ze zelfs; Canning werd gekwetst en beide mannen waren verplicht het ministerie te verlaten. Bij de reconstructie van het ministerie in 1812, waarin Castlereagh werd opgenomen, bleven ze nog verwijderd; de oorlogsstaat, gevoegd bij de herinneringen van 1809, makte pogingen tot toenadering vruchteloos, zoodat Canning in 1814 den betrekkelijk onbeteekenenden gezantschapspost te Lissabon aannam. Maar de gebeurtenissen van 1815 deden in de algemeene vreugde veel vergeven en vergeten; bovendien scheen de vrede nu voldoende verzekerd. Het gevolg was, dat Canning in 1816 te Londen terugkwam, en wel in eene qualiteit, die hem eerlang in rechtstreeksche aanraking met onze staatslieden zou brengen.

De macht der Engelsche Oost-Indische Compagnie had zich in Vóór-Indie gedurende de $18^{\mathrm{e}}$ eeuw anhoudend uitgebreid (a), zonder dat de regeering te Londen in dezelfde mate gezag er over kreeg, hetgeen toch bij de vermeerdering van den staatkundigen invloed der Compagnie en bij de groote misbruiken, die nu en dan aan den dag kwamen, noodzakelijk bleek te worden. De Regeering had geen voldoenden toegang tot de bureelen der Compagnie. Onderzoekingen konden feitelijk slechts plats vinden door benoeming van speciale commissiën of door parlementaire comités. Om aan de gebreken tegemoet te komen, kreeg in 1784 eene regeling van Pitt kracht van wet, volgens welke ingesteld werd een college, de Board of Control geheeten, dat deel van het ministerie uitmaakte, toegang kreeg tot 's Compagnie's archieven, het veto had over de handelingen van de directeuren der Compagnie en bevelen aan de

(a) Zie o. a. de hoofdstukken VII-IX in Factorijen II. 
autoriteiten in Indië kon geven, die de directeuren onveranderd en als uitgaande van henzelven moesten overbrengen. Door de vestiging van deze instelling ging het moederlandsch bestuur der Compagnie's koloniën feitelijk op de kroon over. Het presidentschap van den Board of Control was dus van groot gewicht en dat het financieel ook niet verwerpelijk mocht heeten, blijkt uit Canning's benoeming tot deze betrekking op 5000 pd. st. 's jaars (a). Hierdoor kwam hij weder in het kabinet, waarvan Castlereagh ook lid was en gewerd hem tevens als president eene plaats in het parlement (b). Weliswaar nam dit lid van het ministerie uit den aard der zaak geene eerste plaats in, maar de persoonlijkheid kon er aan eenigszins tegemoet komen, en Canning bleek zeker daarvoor wel de man (c).

Het was nu onder het bestaan van dit ministerie, dat de Nederlandsche commissarissen-generaal naar Batavia zeilden, om ter uitvoering van het tractaat van 1814 de teruggegeven Nederlandsche koloniën over te nemen. Elders heb ik medegedeeld met hoeveel bezwaren dit gepaard is gegaan (d). Voor een deel lag de schuld in de bewoordingen van het tractaat; voor een ander deel in de onwelwillende opvattingen der Britsche plaatselijke autoriteiten in Indië; eindelijk ook in de weinige voortvarendheid bij de regeering in Nederland en in niet geringe mate in de persoonlijkheid van den commissaris-generaal Elout (e).

Wij zullen zien, dat ten slotte de Engelsche regeering klachten bij de onze inbracht, hetgeen geschiedde door tusschenkomst van den Britschen ambassadeur bij ons hof, lord Clancarty. Deze vertegen-

(a) "The East I.dia Company was primarily a commercial company, with directors owing primarily commercial obligations to their shareholders. To assist and guide them in the Imperial responsilibities, which had little by little grown upon them, there was the Board of Control, a department of the British Ministry, the President of which spoke in the name of the Secret Committee, which consisted of representatives of the Company." Egerton's leven van Raffles (1900), bl. 138. Het doel van den Board of Control was: ${ }^{\text {to }}$ check, superintend and control all acts, operations and concernes, which in any wise relate to the civil or military Government or revenues of the territories and possessions of the E. I. Company." Martineau 23.

(b) "On the 10th June (1816), Canning took his place in the House of Commons as president of the Board ot Control." Martineau 23.

(c) In ieder geval geeft de mededeeling op bl. XIX Bijdr. $E$, dat de Engelsche gevolmachtlgden in 1820 waren "Lord Castlereagh en de Minister Canning", tot misverstand aanleiding in zoover dat de eerste ook minister was.

(d) Zie mijne verh. Opvattingen en mijne artikelen over speciale bezittingen.

(e) Zie vooral mijne Elout-verhandeling. 
woordiger had in de dagen, dat de Oranje's buiten Nederland moesten wonen, veelvuldig met den Souvereinen Vorst, weldra Koning, omgang gehad, waaruit eene familiariteit ontstaan was, die, naar Willem I terecht of ten onrechte meende, niet meer te pas kwam, sinds beider maatschappelijke positiën zoo geheel verschillend waren geworden. De Koning schijnt echter geen hart voor werkelijke vriendschap of erkentelijkheid, jegens wien ook, gehad te hebben. Van Hogendorp herinnerde zich van den wantrouwenden Souvereinen Vorst (a) "dat Hij alreeds in de eerste dagen tot mij gezegd had: ik neem Lord Clancarty mede naar Amsterdam, ten einde hem onder het oog te houden". Het open gemoed van Van Hogendorp wist beter zulke mannen te waardeeren en ook die waardeering te toonen: "The first lines I write with my sick hand", schreef de door podagra gekwelde aan Clancarty dd. 29 Januari 1814 naar aanleiding van gemaakte schikkingen, inzonderheid ten aanzien van onze vaart en handel, "are adressed to your Lordship in order to express you my gratitude for the most agreable communications you have given me just now. I shall immediately transmit all your papers to His Royal Highness, but meanwhile I expect His orders, I cannot bear to remain silent, nor to shut up in my heart my admiration of the loyal sentiments of the Prince Regent and His Ministers. I am not now speaking to the Embassador, but to the Earl of Clancarty, who has settled this business with me like a Friend and a Brother." Van Hogendorp teekende nog op de copie van dit stuk aan: "Het is de uitboezeming van een dankbaar hart" (b). Dat ook persoonlijk de Souvereine Vorst redenen van dankbaarheid jegens Clancarty moest hebben, bracht ik bereids elders in hérinnering (c).

II.

\section{Herinneringen aan het koloniaal tractaat van 13 Augustus 1814.}

De Engelsche Oost-Indische Compagnie was sinds 1811 tegen den door haar uitgedrukten wil bezitster van "Java en onderhoorigheden" gebleven (d). Wel rees spoedig na de verovering de gedachte om

(a) Brieven-Hogendorp V, 45.

(b) Brieven-Hogendorp V, 198-199.

(c) Singapore II 373 , ov. 61 ; men zie mede over Clancarty die verhandeling bl. $336-337$, ov. $24-25$.

(d) Zie noot 1 Sluiting. 
het verkregene tot kroonkolonie te maken, doch het kwam eerst in October 1813 tot een punt van ernstige overweging; ten slotte werd inderdaad beslist, dat de voormalige Nederlandsche koloniën aan den koning van Groot-Brittannië moesten overgaan (a). Ware dit geschied, de teruggave aan Nederland zou meer voeten in de aarde hebben gehad. De overgang werd echter door het ministerie bevolen juist in de dagen dat Nederlands verlossing van het Fransche juk bekend werd; hierin vond de Britsche minister Bathurst aanleiding, het stuk weer in te trekken. Vandaar dat, als Van Hogendòrp den minister om inlichting vraagt over het door de Engelschen op Java ingevoerde stelsel, deze dd. 31 October 1814 het volgende antwoordt (b):

"Your Excellency's wish to have communicated to you an account of the changes, which you have understood have been introduced into the management of Public Revenues and civil administration of Java, shall be attended to. That account is not in my office, but I will apply to the Board of Control, who may be in possession of it. "I ought however to apprize Your Excellency, that whatever changes have been introduced into Java have been of a temporary nature, and therefore probably less worthy of Your Excellency's attention. The East-India Company had only the government of Java for a time, until it was made over to His Majesty, and under these circumstances there was probably no very well considered system introduced. The instrument by which Java was to be delivered over to His Majesty was signed by me the week in which the account was received of the Revolution breaking out in Holland, and I immediately ordered the instrument to be withheld (and it was afterwards cancelled), because I thought that the act of making it own to His Majesty would give the appearance of our intending to keep it at a Peace, at a time, when the glorious news from Holland gave us a prospect of seeing the House of Orange restored; and I conceived that our appearing to choose that moment to take to ourselves, what I know to be a possession much cherished by the Dutch Nation, would be prejudicial to the Orange interests and discreditable to the British character."

Zoo blijkt het geheel juist, wat ik elders reeds opgaf als de redenen, waarom de overgang op de Britsche kroon van de Nederlandsche koloniën niet doorging.

(a) Zie noot 2 Sluiting.

(b) Brieven-Hogendorp V, 199-200. 
De algemeene vreugde toch in Engeland over de gebeurtenissen van 1813; inzonderheid sympathie voor den in ballingschap wonenden Erfprins van Oranje en zijn huis, niet minder voor Nederlands eigen optreden tegen de Fransche overheersching; politieke overwegingen om, nevens de vereeniging met België, ook door koloniaal bezit ons vaderland zó krachtig te maken, dat het als een bolwerk tegen Fransche veroveringszucht kon beschouwd worden; eindelijk de gedachte om door het toonen van waardige zelfbeperking in territoriale hebzucht een invloedrijk voorbeeld aan de overige mogendheden te geven, die Europa ieder naar hare eigen belangen zochten te verdeelen: zoovele oorzaken, die Engeland vervulden met - om de woorden van Castlereagh te gebruiken - het bijna romantisch streven ons vaderland ter wille te zijn door de teruggave der koloniën (a).

Vol erkentelijkheid antwoordde Van Hogendorp dd. 10 November 1814 den minister Bathurst aldus (b):

"Agréez mes remerciments pour la bonté qu'a eue Votre Excellence par sa lettre du 31 Octobre de m'accorder le rapport sur l'Tle de Java, que j'attends avec d'autant plus d'impatience, que je vois par les Gazettes de Batavia combien de nouveaux réglements y ont été introduits.

"Je reconnais le caractère anglais dans l'annulation de l'instrument par lequel Java venait d'être réuni à la Couronne la même semaine de notre Révolution. Votre Excellence m'a fait un sensible plaisir en me communiquant ce trait de loyauté... (c). Le discours du Prince Souverain à l'ouverture des États Généraux est sans doute entre les mains de Votre Excellence, sans quoi je le lui aurais adressé. Il a. produit ici le meilleur effet, et je me flatte qu'en Angleterre il fera répéter un mot de Lord Clancarty, que cet ambassadeur me dit dans une autre occasion: You are not a noisy people. Nous avons travaillé dans le silence."

Trouwens, reeds in den aanvang van 1813 mocht de Prins van Oranje ten aanzien van de teruggave der koloniën de meest geruststellende verzekering ontvangen (d). Nadat de gebeurtenissen voor Europa's bevrijding steeds gunstiger keer namen, dus met het ten einde loopen van dat jaar, kwam de zaak nu en dan weder ter sprake. Den $11^{\text {n }}$ November 1813 schreef de Prins aan H. E. C. von
(a) Zie Sluiting 247-248; ov. 9-10.
(b) Brieven-Hogendorp V, 200.
(c) Aldus met stippels afgedrukt in de Brieven-Hogendorp.
(d) Zie noot 10 Sluiting. 
Gagern, dat hij wel inzag, dat van geene andere mogendheid eene welwillende opvatting viel te verwachten dan van Engeland en dat Castlereagh hem in het algemeen de teruggave der koloniën, behoudens enkele niet genoemde, had toegezegd (a).

Onder de mannen, die in Engeland den Prins ter zijde stonden, behoorde H. Fagel. Aan dezen meldde G. K. van Hogendorp dd. 28 November 1813 het heugelijk bericht, dat de omwenteling haar beslag had gekregen, dat de Prins slechts behoefde over te komen, om zich aanstonds door het gansche volk als Souvereinen Vorst toegejuicht te zien, en dat men dus ook geheel medeging met Engelands politiek. "En vous donnant, Monsieur, ces assurances" luidt het geestdriftig schrijven (b) - "en entrant parfaitement dans les vues de l'Angleterre, je dois en même temps faire connaître à celle-ci ce qu'attend d'elle ma patrie; c'est la restitution prompte et sans réserve des colonies dans les trois parties du monde. Nous nous lierons à l'Angleterre par des noeuds indissolubles, nous serons tout à elle, mais nous avons la ferme confiance qu'elle ne gardera rien de ce qui est à nous." Maar dan haast zich Malmesbury, aan wien Fagel den brief liet lezen, bij schrijven dd. 3 December 1813 die hooge verwachtingen over de teruggave te temperen met een niet alles en niet dadelijk of in ééns (c). In beschermenden toon gaf de Britsche minister zijne hooge tevredenheid over Van Hogendorp's epistel te kennen, het vertrouwen uitsprekende, dat "if he continues to act on the same principles", alles wel goed zou gaan; doch, vervolgde Malmesbury, al was het nu ook natuurlijk, dat in de eerste opwelling van geestdrift men al de koloniën wilde terughebben, "on more calm reflection" zou Hogendorp er wel anders over gaan denken, daar de verdediging van De Kaap en Ceylon eene sterke militaire macht vorderde en dus: "safer in our possession than on being restored to them". - Voor Van Hogendorp zal dit wel eene groote teleurstelling geweest zijn, had ik, dacht me, het recht te schrijven in 1897 naar aanleiding dezer correspondentie (d); maar in 1902 verscheen het VI ${ }^{\mathrm{e}}$ deel der Brieven en Gedenkschriften van Gijsbert Karel, en daarin is onder dagteekening van 17 Juni 1814 over de Kaap en Ceylon aldus de door hem gestelde vraag: "Wanneer de Engelschen ons de Oost-Indische Bezittingen terug-
(a) Zie noot 11 Sluiting.
(b) Zie noot 12 Sluiting.
(c) Zie noot 13 Sluiting.
(d) Zie Sluiting 249; ov. 11. 
geven, hetzij op den voet van 1794 of van 1802, en dan over eenigen derzelven willen handelen; welke zouden wij dan kunnen missen ?" - aldus geantwoord (a):

"Van de Bezittingen aan Nederland toebehoorende in Oost-Indie in 1794 hebben de Engelschen bij den vrede van Amiens in 1802 zich het bezit van Ceylon voorbehouden. Deze aanwinst was voor hen van het grootste aanbelang, zoowel uit hoofde van de belangrijkheid van dat eiland, als wegens deszelfs ligging bij hunne andere Bezittingen, en voornamelijk om de haven van Trinconomale die voor hunne zeemagt in alle seizoenen eene veilige ankerplats verschaft, die hun in den Golf van Bengalen en langs de kust van Chormandel geheel ontbrak. Of nu deze afstand van 1802 door de Engelschen als finaal zal beschouwd worden, of Ceylon weder als een voorwerp van onderhandeling aangezien, is de vraag, die het eerst in aanmerking komt. Zoo het eerste plaats vindt, valt er niets verder over te zeggen. In het tweede geval zouden dan die Bezittingen misschien het eerst in aanmerking komen om er over te handelen. Onder het Bestuur van de voormalige Oost-Indische Compagnie was Ceylon reeds een lastpost geworden, omdat de onkosten van bestuur en verdediging verre te boven gingen de voordeelen en winsten die deze Bezitting, in weerwil van het rijke product van Caneel door de gebrekkige administratie en inrigting van inwendig bestuur, aan de Maatschappij opbragten.

"Ofschoon nu wel onder eene betere administratie deze bezitting meerdere voordeelen zoude kunnen geven en althans ruim de onkosten van deszelfs bestuur en verdediging goedmaken, zoo zal echter altoos zijne ligging, digt onder de Engelsche Bezittingen en verwijderd van de onze, hetzelve ten minste relatief van minder belang voor ons doen zijn, dan andere bezittingen meer in verband staande en nader gelegen aan onze hoofdbezittingen, en dus, indien er over een afstand gehandeld moest worden, in aanmerking kunnen komen.

"De Kaap de Goede Hoop, nu ook reeds tweemalen door de Engelschen veroverd, wordt zeker door hen van groot aanbelang en als een beveiligend bolwerk voor hunne aanzienlijke Aziatische Bezittingen beschouwd. In den tegenwoordigen stast van zaken en de naauwe staatkundige en vriendschappelijke betrekkingen tusschen dat land en ons, volgens dewelke, als bijna dezelfde belangen hebbende, wij in de Engelsche overmagt ter zee de veiligste zekerheid en defensie voor onze Oost-Indische Bezittingen mogen

(a) Zie dl. VI, 507. 
vinden; zoo zoude men ook uit hetzelfde oogpunt, de possessie van de Kaap, verdedigd door de Engelschen, evenzoo voordeelig en nuttig voor de veiligheid van onze bezittingen kunnen beschouwen, als of wij zelve daar meester van waren. Ja, mogelijk nog voordeeliger; want zeker zal de Kaap niet ligt, en althans in de eerste tijden niet, zoo veel kunnen opbrengen om de kosten van deszelfs bezetting en verdediging te kunnen goedmaken."

Als dus op het einde van 1813 Van Hogendorp misschien zich teleurgesteld gevoeld mocht hebben op het bericht van Ceylon en de Kaap niet te zullen terugkrijgen, zeker is het in ieder geval dat hij medio 1814 zich in dit verlies geschikt had, niettegenstaande eigen belangrijke financieele belangen hem het anders gewenscht moesten doen voorkomen, om De Kaap terug te erlangen.

De losse besprekingen over de teruggave der koloniën konden niet het onderwerp van gezette behandeling worden, zoolang er nog strijd tegen Napoleon's leger werd gevoerd; doch met de verbetering van de toestanden, schreef de Souvereine Vorst dd. 8 April 1814 aan Van Hogendorp: "Omtrend de Colonien en de handel op dezelve is misschien ook binnen kort het oogenblik van de intentien te verneemen, daar de Conventie, dewelke gesloten is, ten minsten een gedeelte van onze aanstaende grense bepaald, en deeze de latitude geeft van hetgeen wij zullen zijn, alsmeede onze middelen om ons binnen en buiten Europa te defendeeren. Het zal altoos nodig zijn den Ambassadeur en zijn Gouvernement in goed humeur te houden, en alles wat daartoe contribueeren kan is wenschelijk" (a). - Wij zullen zien, hoe weinig koning Willem I zelf de kunst zou verstaan den Ambassadeur en zijn Gouvernement in goed humeur te houden! Van Hogendorp antwoordde nog denzelfden $8^{\mathrm{n}}$ April over lord Clancarty: "De Ambassadeur heeft mij als in het voorbijgaan gezegd, dat de restitutie van onze Kolonien afhing van dat wij sterk genoeg zouden zijn om onze onafhankelijkheid te bewaaren, en dat ik zeer wel wist wat Engeland voor had om ons sterk te maaken" (b). Den volgenden dag richtte Van Hogendorp zelf een schrijven er over aan lord Castlereagh. Misschien was dit zijne eerste rechtstreeksche correspondentie met den Britschen minister omtrent deze belangrijke aangelegenheid; althans wij lezen de volgende mededeeling uit zijne latere herinneringen betrekkelijk den aanvang van 1814 (c): "Omtrent de

(a) Brieven-Hogendorp V, 362.

(b) Brieven-Hogendorp V, 364.

(e) Brieven-Hogendorp V, 51. 
kolonien zelve gaf Lord Castlereagh alle verzekering aan den Prins. Ik had deze snaar niet met hem geroerd, omdat ik al vroeger en in de eerste dagen daarover geschreven had aan den ambassadeur Fagel en tot antwoord gekregen, dat wij onze kolonien nog niet konden bewaren, dog dat wij zo verre zijnde, dezelve met vrugt zouden kunnen wedereischen. Van dat ogenblik achtte ik het beter, om zo lang geheel daarvan te zwijgen. Maar het schijnt, dat Lord Castlereagh deze verzekering ongevraagd gegeven heeft. Althans hij had twee uren bij mij gezeten, om over alle onze zaken te handelen, en was opgestaan met de woorden: nu zijn wijj, geloof $i k$, den kring rondgelopen, en ik moet mij nog kleeden voor het middagmaal bij den Prins. - Ik kwam aan het Hof vóór hem en Z. H. zeide mij: het is mij lief, dat hij zo lang bij $U$ gebleven is, hoe langer hoe beter. - $\mathrm{Na}$ den eten verhaalde $\mathrm{Z}$. H. mij de verzekering omtrent de Kolonien, er bij voegende, dat Engeland denkelijk voor de Kaap geld bieden zou." — Dit moet dus voorafgegaan zijn, toen Van Hogendorp dd. 9 April 1814 aan Castlereagh een langen brief zond, waarin het volgende over de koloniën voorkwam (a): "Maintenant que nos limites futures sont déjà fort étendues, que notre armée se rassemble, et que nous allons assiéger Anvers, tandis que d'un autre côté Louis XVIII est proclamé, n'est-il pas tems, Mylord, de songer à nos Colonies. Pardonnez-moi un peu d'ardeur sur ce point, parce qu'il tient à nos intérêts les plus chers et qu'il m'a semblé que la Grande Bretagne, toujours grande et généreuse, n'y met d'autre condition, que celle de nous voir assez forts pour nous défendre et pour maintenir nos possessions. Vous ne voulez que notre indépendance pour la conserver, vous désirez que nous soyons riches, vous déclarez que nous devons recouvrer nos richesses par le commerce, et ce commerce ne redeviendra ce qu'il fut jadis que par les Colonies. Encore une fois, Monsieur, pardonnez à mon patriotisme, que vous approuverez, cet élan peutêtre inđiscret." -

Bij deze onzekerheid rees tevens de vraag of de teruggave der koloniën zou worden behandeld bij het met Frankrijk eerlang aan te gane vredestractaat dan wel op het destijds reeds voorgenomen congres te Weenen, of eindelijk uitsluitend met Engeland. Onze Londensche ambassadeur H. Fagel, aan Buitenlandsche Zaken dd. 9 Mei 1814 schrijvende, dat hij alsnog bij het Britsche ministerie stappen zou doen voor het openen der onderhandelingen, verwachtte dat de

(a) Brieven-Hogendorp V, 459. 
quaestie hetzij bij het vredestractaat, hetzij op dat congres zou uitgemaakt moeten worden, wegens het verband met andere restituties $(a)$. Maar noch aan gene zijde van het Kanaal, noch vooral door ons werd deze bondgenootschappelijke behandeling wenschelijk geacht; onze bewindslieden, evenals de Souvereine Vorst, evenals Hogendorp, zagen terecht wel in, dat veel meer te verwachten was van de persoonlijke sympathieën, die destijds tusschen Engeland en Nederland bestonden, dan van eene algemeene vergadering, waar het pas weder in het leven geroepen staatje - als andere kleine staten in die dagen, een sons-allié spottend geheeten! - niets te zeggen zou hebben (b).

Den $30^{\mathrm{n}}$ Mei 1814 was het vredestractaat van Parijs tot stand gekomen, en wel met de bepaling, dat Zweden aan Frankrijk zoude teruggeven het eiland Guadeloupe, "en consequence d'arrangemens pris avec ses alliés".

Eene week na dien vrede, namelijk dd. 7 Juni 1814, schreef minister Van Nagell opnieuw onzen ambasadeur te Londen over het openen der koloniale onderhandelingen $(c)$; den $11^{\mathrm{n}}$ bezocht Fagel lord Castlereagh. Deze onderhield hem over het verlies van een onzer aan Zweden af te stane bezittingen wegens Guadeloupe, waarvan echter de ambassadeur niets wist, zijnde er geenszins over ingelicht. "Mais ce que lord Castlereagh m'a expressément prié de porter à votre connaissance", rapporteerde den $11^{\text {n }}$ Fagel aan Buitenlandsche Zaken, "c'est que comme ces affaires, en particulier celle des colonies, allaient être mises ici sur le tapis sans delai, il priait que vous voulussiez faire passer incessamment soit à moi, soit à telle autre personne que Monseigneur le Prince voudra honorer de cette commission, les plein-pouvoirs et instructions necessaires. Ceci s'accorde, à ce qu'il me paraît, avec les intentions énoncées dans la dépêche de V. E. $\mathrm{n}^{0} 66$ du 7 de ce mois" $(d)$. - Had Van Nagell in dien brief van den $7^{\text {n }}$ geschreven, dat men "naturellement" moest onderhandelen op den grondslag van ons bezit in $1792(e)$, m. a. w. dat wij zouden terugkrijgen de Kaap, Ceylon, de Oost, de West, bovenal het zoo kostbaar geachte Guiana, weldra zou het blijken,

(a) Zie het schrijven in noot 34 Sluiting.

(b) Zie hierover breeder Sluiting 254-255; ov. 16-17. Van Hogendorp's oordeel vindt men in Brieven-Hogendorp V, 72 .

(c) Zie het schrijven in noot 36 Sluiting.

(d) Zie den brief in zijn geheel noot 37 Sluiting.

(e) Zie noot 36 Sluiting. 
dat voor Guadeloupe men het booze oog juist op een deel van deze laatste kolonie had geslagen. Van Nagell stelde de volledige teruggave van Guiana op zoodanigen hoogen prijs, dat hem dit punt der koloniale quaestie boven alles ter harte bleek te gaan; trouwens mannen als Kluit en andere vaderlandslievende landgenooten oordeelden er in die dagen eveneens zoo over $(a)$. Af te zien van Essequebo, van Demerary, van diezelfde streken, waaromtrent toch lord Malmesbury met zoovele woorden dd. 3 December 1813 uitdrukkelijk had geschreven : I certainly would give you back, zou eene teleurstelling zijn, die men met alle macht moest trachten te voorkomen. Dezen gedachtengang legde Van Nagell, op ontvangst van het gezantschapsbericht, aanstonds neder in een schrijven dd. 16 Juni 1814, waarin hij voor den Souvereinen Vorst ontworpen had eene aan Fagel te verstrekken instructie (b). De Vorst achtte het noodig hierover eene vergadering met eenige andere staatslieden of deskundigen te houden. Ziehier hoe Van Hogendorp de behandeling dezer aangelegenheid afkeurend in zijne latere herinneringen verhaalt $(c)$ : "De Prins riep eenige Ministers in zijn Kabinet, mij, de Heeren van Nagell, Falck, den Generaal Janssens, om de instructiën, door den Heer Nagell ontworpen, te beoordeelen. Ik twijfel of de Generaal Janssens toen reeds Minister van Oorlog was, en meen zeker, dat hij als gewezen Gouverneur van de Kaap en van de Oost, misschien als gedoodverwd tot dezen laatsten post, was geroepen. Ik herinner mij zeer wel, dat ik den volgenden dag mijne groote verwondering aan Falck betuigde, over zo gewigtige Staatsbelangen met eenen man gezeten te hebben, die vier maanden onder Buonaparte tegen ons gestreden, en hem in de laatste week van zijn regeering eerst verlaten had. De ontworpen instructien strekten om alle onze oude Kolonien terug te vragen, Ceylon bij den vrede van Amiens afgestaan, en Negapatnam in 1783. Ons regt daarop werd betoogd. Ik was van oordeel, dat wij op de edelmoedigheid der Engelschen en niet op ons regt moesten bouwen. De instructiën werden egter verzonden ...."

De eerste missive van Fagel dd. 21 Juni 1814 over de geopende onderhandelingen meldde, dat wij zoo goed als alle koloniën zouden terugkrijgen, behalve De Kaap, waarvoor, gelijk onze Minister reeds

(a) Zie noot 38 Sluiting.

(b) Zie breeder, ook over deze instructie: Sluiting 255-259; ov. 17-21.

(c) Brieven-Hogendorp V, 72. 
goedgevonden had, eene aanzienlijke som gelds ten behoeve der barrière-steden werd toegezegd $(a)$. De Britsche regeering wilde volstrekt niet, had Castlereagh verzekerd $(b)$, zich inhalig betoonen. Cochin op de kust van Malabar zouden wij echter ook wellicht verliezen; en wat betrof de Guadeloupe-quaestie, nu wij eene veel aanzienlijker vergrooting van ons gebied in Europa verkregen dan oorspronkelijk voorzien was, zouden wij dan toch ook wel, meende de Minister, geen bezwaar hebben tegen den afstand van het enkele Berbice aan Zweden; daarentegen zou deze mogendheid, oordeelde Castlereagh, zich hiermede hebben tevreden te stellen al was het ook minder dan Guadeloupe, wijl de rechtstitel veel zekerder werd (c).

Het zoude eene gelukkige gedachte zijn geweest, indien Van Nagell, overeenkomstig Van Hogendorp's oordeel, onmiddellijk op dezen brief van onzen ambassadeur was ingegaan, bedenkende dat gevoelens van edelmoedigheid in den regel kort verloop hebben en dat wij dus, hoe meer tijd wij over de zaak deden gaan, steeds in minder gunstige omstandigheden konden komen. "Avec les Anglais", zegt zoo naar waarheid, en Van Nagell zou het ondervinden, Francis Charmes (d), "si l'on doit finalement céder, il vaut mieux le faire immédiatement, car il est dans leur pratique habituelle d'augmenter leurs prétentions à mesure que la négociation se prolonge. Ils prennent tout ce qu'on leur offre, et ils demandent autre chose."

Wel verre dan aan onzen gezant te bevelen Castlereagh bij zijn woord te houden, lokte de Minister geene wijziging uit in zijne veeleischende instructie, bij schrijven van 24 Juni 1814 aan Fagel gezonden (e).

Te vergeefs trachtte Fagel in zijn antwoord van 30 Juni 1814 het hopelooze van dergelijke basis tot onderhandeling aan te toonen. Zijne waarschuwing wekte bij den Minister slechts bitterheid en hartzeer op, blijkens zijn antwoord van 8 Juli d. a. v.; het verlies van Guiana stond gelijk met het afsnijden van onze levensdraden! $(f)$ Intusschen hadden zich de Czaar van Rusland en de Koning van Pruisen, benevens onderscheidene eerste ministers naar Londen begeven; de werkzaamheden voor het Britsche ministerie hieruit

\footnotetext{
(a) Zie noot 45 Sluiting.

(b) Zie noot 7 Stuiting.

(c) Zie de noten 46 en 47 Sluiting.

(d) Zie de Revue des Deux Mondes van 15 September 1899 bl. 478.

(e) Zie het schrijven in noot 48 Sluiting.

(f) Zie de correspondentie in Sluiting 260-261; ov. 22-23.
} 
voortvloeiende, werden zéér vermeerderd door de geopende parlementaire debatten, terwijl het overige van den tijd door talrijke feesten werd ingenomen; het resultaat was, dat voorloopig Castlereagh niet over onze koloniale zaken was te spreken. En toen onze ambassadeur eindelijk daartoe gelegenheid vond, bleek de Britsche minister onder Van Nagell's verzet zijn geduld te hebben verloren. Eene zeer gewichtige niet-koloniale quaestie kwam trouwens daarbij. Omtrent de voorwaarden der vereeniging van Noord- en Zuid-Nederland was te Londen door de verbondenen een stuk opgemaakt, hetwelk de Souvereine Vorst behoorde te teekenen; doch deze maakte bezwaar wegens het onbestemde der regeling van de schulden-quaestie tusschen beide deelen; verder wijl de grenzen van den te scheppen staat nog niet behoorlijk waren aangewezen; eindelijk omdat het land door vreemde troepen bezet bleef. Aldus ontmoette Castlereagh èn in de koloniale quaestie, èn in de vereeniging der Nederlanden - beiden met name door hem in het leven geroepen en geleid - een naar zijn inzien ondankbaren wederstand bij den Vorst en zijne regeering, die hij slechts met weldaden toonde te willen overladen. De besprekingen met onzen gezant afbrekende, wegens Van Nagell's ontevreden tegemoetkoming, verklaarde hij niets verder te zeggen te hebben; Nederland kon zonder België niet sterk genoeg geacht worden voor de verdediging van kostbare koloniën en de zaak moest dan maar op de eindbeslissing van het Congres wachten. Mistroostig en niet zonder scherpte, schreef den $15^{\mathrm{n}}$ Juli 1814. Fagel dit bedroevend resultaat aan onzen minister, nadat evenzoo door Castlereagh deze beslissing den vorigen dag aan den Britschen gezant in Den Haag, lord Clancarty, was bericht. Fagel gaf in de betuigingen van zijn leedwezen, dat men zich niet vriendschappelijk had weten te verstaan, duidelijk genoeg te kennen, dat Van Nagell eigenlijk den normalen gang had verstoord en verknoeid $(a)$.

In dit moeilijk tijdsgewricht kwam weder Gijsbert Karel van Hogendorp vredestichtend tusschenbeiden. Wij zagen hiervóór (b), hoe hij heeft verhaald, dat tegen zijn wil de veeleischende instructie aan Fagel was verzonden geworden. Op deze mededeeling laat hij dan dit volgen: "Welras kwam de tijding dat Lord Castlereagh, op het hooren van onze eischen de handeling afgebroken en verklaard had, dat deze zaak met alle de anderen in Weenen zou verhandeld

(a) Zie dit alles met aanhaling van bronnen in Sluiting 261-262, ov. 23-24.

(b) Op bl. 31.

$7^{\circ}$ Volgr. II. 
worden. Daarmede hingen wij af van alle de strijdende belangen, en verloren een kostelijken tijd. Ik nam de pen op en schreef een hartelijken brief aan Lord Castlereagh. Ik zond hem aan Z. H., die er flauw op antwoordde, dog zonder zig tegen te verklaren. Ik wees hem aan Falck die hem overschoon vond, en bad te verzenden. Uit de Engelsche couranten zag ik vervolgens, dat den eenen dag in het Hoogerhuis door Lord Liverpool verzekerd werd, dat de zaak naar Weenen ging, en den anderen, dat zij in Londen afgedaan zou worden" $(a)$.

Belangstellend vraagt men nu, of die brief dan niet in de Verzameling-Hogendorp is medegedeeld. Men zal wel niet ver van de waarheid af zijn, wanneer wordt aangenomen, dat het bedoelde stuk 'n paar honderd bladzijden verder in deel V, namelijk op bl. 400-402, is afgedrukt. Deze ontwerp-brief verdient in ieder geval volledig te worden weergegeven:

La Haye ce 4 Juillet 1814 .

Mylord!

J'ai attendu quelque temps pour féliciter votre Excellence de l'heureuse issue de ses négociations pour la délivrance de l'Europe et je Lui porte aujourd'hui l'hommage de ma reconnoissance et de mon admiration. Je me suis acquitté de ce même devoir envers S. M. l'Empereur de Russie, qui a recueilli sur son passage en Hollande le tribut de la gratitude nationale, que nous lui avons apporté de la manière la plus franche. Ce Prince a pu voir dans l'enthousiasme excité par sa présence tout le secret de notre révolution. Les Hollandois sont animés d'un sentiment profond, ordinairement calme et presque renfermé dans les coeurs, mais qui dans les grandes occasions se manifeste avec d'autant plus d'énergie. C'est un sentiment de ce genre, qui les attache à la Maison d'Orange et qui les rend amis de l'Angleterre; car il y a un lien intime entre l'Angleterre et cette Maison, resserré particulièrement par le Roi Guillaume, et qui est à l'abri de toute atteinte. Des jours aussi beaux que ceux de I688 vont peutêtre luire pour nous, et j'ose assurer votre Excellence que cela ne dépend que de l'Angleterre, et qu'elle tient entre ses mains la plus intime union avec nous. Des trois grands objets, dont il s'est agi dans les conférences que j'ai eu l'honneur d'avoir avec Elle cet hiver il en est un qui s'est évanoui de la manière la plus déplorable. Je plains du fond de mon coeur le jeune Prince, dont la sensibilité a souffert une si rude épreuve, mais je me plais.dans l'idée,

(a) Brieven-Hogendorp V, 72-73. 
que devenu plus cher à sa nation, il n'est pas moins aimé de la Vôtre (a). Il reste les deux grands intérêts de la Belgique et des Colonies. L'incertitude et les délais sont à cet égard tout ce qu'il y a de plus à craindre. Vous avez, Mylord, traité la France avec beaucoup de magnanimité. Vous avez établi la paix sur les bases les plus libérales. J'ose dire que vous vous trouverez bien de suivre les mêmes maximes dans votre alliance avec nous. Loin de l'Angleterre, si puissante aujourd'hui, les petits moyens et les futiles appréhensions. Vous voulez que nous soyons forts et vous pouvez nous le rendre. Nous ne le serons jamais que par l'opulence et par le commerce maritime, ainsi que vous l'avez dit. Notre commerce et nos colonies sont pour vous un garant de plus de notre fidélité, car tous deux seront toujours entre vos mains, considérables par votre protection, ou anéantis par votre ressentiment. Règlez nos intérêts maritimes et territoriaux avec autant de sagesse que de grandeur, et attachez-vous une nation simple et loyale, qui est plus capable qu'aucune autre de reconnoissance. Si j'étois Anglois je ne vous parlerois pas autrement, et vous savez que je professe le maxime qu'un bon Hollandais doit être Anglois. Nous posons aujourd'hui les fondements d'une union, qui doit braver les sciècles, et les hommes d'état de celui-ci ont à travailler pour les générations futures. Votre nom, Mylord, est honorablement attaché au Traité, qui va fixer le sort de ma patrie, et je me réjouis de voir ses intérêts entre vos mains. - Les conditions seront aussi justes, aussi nobles, aussi simples, que le caractère de celui qui les dictera. On assure que Votre Excellence se rend au Congrès de Vienne; que ne puis-je jouir une seconde fois du bonheur de l'entretenir. T'aurais un plaisir extrême de l'assurer encore des sentiments invariables avec lesquels je serai toute ma vie,

\section{Mylord, \\ de Votre Excellence}

le très humble et très obéissant serviteur Charles de Hogendorp.

P.S. Si Elle me fait la grace de m'écrire je prie que se soit toujours en Anglois.

Van Hogendorp zond dezen ontwerp-brief aan den Souvereinen Vorst bij volgend schrijven:

(a) Dit heeft betrekking op het afbreken van de verloving tusschen de dochter van den prins van Wales, prinses Charlotte, en den oudsten zoon van den Souvereinen Vorst, den prins van Oranje. We zullen hierna zien, dat het gespatieerde uit den brief is geschrapt en dientengevolge de tekst daar eenigzins werd gewijzigd. Zie ook over dit huwelijk Brieven-Hogendorp $\mathrm{V}, 64-65,399$. 
Ik neem de vrijheid om den ingesloten brief aan Lord Castlereagh ter goedkeuring van UKH. aan te bieden. Hoezeer ik niet precies van alle de omstandigheeden onderrigt worde, heb ik er genoeg van vernomen om te begrijpen, dat een hartelijk woord van pas kan zijn.

's Hage

4 Julij I8I4.
$\mathrm{UKH}$. getrouwe onderdaan HOGENDORP.

Waarop het volgende koele antwoord kwam:

Indien UWEG. noodig oordeelt in de tegenwoordige omstandigheden aan Lord Castlereagh te schrijven. wensche ik dat hetgeen het huwelijk van mijn oudsten zoon betreft niet aangeroert werde. Ik houde mij overtuigd, dat $\mathrm{L}^{\mathrm{d}} \mathrm{C}$. het met ons zeer goed meend en byzonder het interest van Holland behartigt, dog eene vreemde zijnde en niet de nuodige informatien bekomende of wegens gebrek aan tijd kunnende erlangen, zoo beantwoorden de resultaten niet altoos aan de verwagting.

's Haage, den 6 July I8I4.

\section{WILLEM.}

Op aandrang van Falck, naar wij lazen, liet Van Hogendorp, den brief afgaan, doch met weglating overeenkomstig het vorstelijk verzoek van de woorden over het mislukte huwelijk (a).

Voor de kenschetsing van menschen en toestanden is deze correspondentie zeer zeker belangrijk, maar lettende op de data heeft ze geen invloed gehad op Castlereagh's afwijzende houding. Wel daarentegen brachten de mededeelingen van Clancarty aan den Souvereinen Vorst in den avond van den $19^{\text {n }}$ Juli 1814 dezen tot nadenken en deden ze hem beslissen het z.g. Londensche protocol te onderschrijven, waarbij "de administratie van België" werd anvaard (b). Van Nagell berichtte de aanneming van het Protocol aan onzen gezant te Londen bij brief van 22 Juli 1814. Noch deze Minister, noch de Souvereine Vorst schijnt echter idee te hebben gehad, dat ook de hooge koloniale eischen, en niet uitsluitend de Belgische quaestiën, tot het afbreken der koloniale onderhandelingen hadden geleid. Geene wijzigingen werden dus in de instructiën gebracht, toen nu Fagel opgedragen werd die onderhandelingen te heropenen, ja de Vorst schreef uitdrukkelijk aan Fagel, dat de vergrooting met België daarop geen invloed mocht uitoefenen $(c)$.

(a) Onder aan de minuut heeft Van Hogendorp gesteld: „N. B. 8 Juillet J'ai montré cette lettre à S. A. R. et par son avis j'ai rayé ce qui regardoit le mariage." Zie Brieven-Hogendorp V, 400 en 402.

(b) Breeder in Sluiting 262; ov. 24. Men zie de acht artikelen van dit protocol o. a. in Brieven-Hogendorp V, 502-504.

(c) Zie uitvoeriger Sluiting 262-263; ov. 24-25. 
In dit kort tijdsverloop was echter de zaak nog veel hopeloozer geworden. Ziehier de treffende illustratie van Charmes' eigenaardige opmerking, hiervoren aangehaald $(a)$. Den $13^{\text {n }}$ December 1813 had Malmesbury aan Fagel geschreven, dat we al de West-Indische koloniën, Essequebo, Demerary, Suriname, zouden terugkrijgen. Een paar maanden later had een onderhoud tusschen Clancarty en den Souvereinen Vorst plaats, waarin deze gereedelijk goed vond den afstand van West-Indische koloniën, terwijl Castlereagh toen op het oog had Berbice, doch ook niet meer, schreef hij aan lord Liverpool dd. 19 April 1814. Bij deze zelfbeperking ten aanzien van West-Indië bleek Castlereagh nog gebleven te zijn in een onderhoud, dat weder een paar maanden later plaats vond met Fagel en waarvan deze dd. 21 Juni 1814 rapport deed. Maar als eene maand weer later, nl. den $28^{\mathrm{n}}$ Juli 1814, Fagel opnieuw met den Britschen minister een onderhoud heeft, bemerkt hij dat de hekken geheel zijn verhangen. Castlereagh toont namelijk er in te berusten, dat Zweden de regeling volstrekt niet goed vindt, dat het toch, behalve Berbice, ook nog wil hebben Demerary en Essequebo, en dat het zich in geen geval wil laten afschepen, gelijk was voorgesteld, met Curaçao, St. Eustatius, St. Martin en Saba : zelf's al gaf men Berbice op den koop toe! Engeland zou het natuurlijk licht gevallen zijn om de veeleischende mogendheid tot andere gedachten te brengen, doch zijn belang bracht onverwacht die verhooging van eischen mede. In genoemde koloniën, vooral in Demerary en Berbice, stak veel Engelsch kapitaal; men wilde ze daarom zelf gaarne hebben. Men zou echter uit de rol van Edelmoedige, Belangelooze vallen, indien men ze zoo rechtstreeks maar aanhield. Niet Engeland eischte ze, maar Zweden, en Zweden verkocht ze aan Engeland. Mochten wij hiervan soms het onze denken, de Britsche minister gaf nu gezant Fagel den veel beteekenenden wenk: niet te vergeten, dat hier van eene gelijk opgaande verbintenis eigenlijk geene quaestie was, daar de eene partij slechts had te geven, en de andere enkel te ontvangen, die dus maar tevireden moest zijn met hetgeen aldus werd verkregen. De toon, waarmede de hervatting van de onderhandelingen begon, was dus heel wat minder vriendelijk geworden; immers tot dusver had men altijd vooropgesteld, dat de teruggave eene quaestie van recht en het dezerzijds opgeven van eene enkele kolonie eene sacrifice was. Fagel deelde het in den ochtend

(a) Op bl. 32 . 
van 28 Juli 1814 verhandelde minister Van Nagell den volgenden dag mede $(a)$.

Den $30^{\mathrm{n}}$ had eene nieuwe conferentie tusschen Castlereagh en Fagel plaats, waarbij de minister als ultimatum de schets van een verdrag aanbood. Tegelijkertijd schreef deze erover aan gezant Clancarty, ten einde ook langs dezen weg minister Van Nagell met de stellige bedoelingen der Britsche regeering bekend te maken. Fagel haastte zich Buitenlandsche Zaken te waarschuwen tegen het maken van verdere bezwaren, hetwelk tot niets anders kon leiden dan tot ontevredenheid, uitstel der overgave en tot de zoozeer gevreesde behandeling der zaak op het Weener congres. Hij adviseerde daarom tot dadelijke aanneming, er andermaal aan herinnerende, dat de Britsche minister telkens, tonjours, verzekerde: D'ailleurs notre parti est pris; c'est à nous de juger de ce qu'il nous convient de rendre ou de garder (b). Dit juist was het geweest, dat Van Hogendorp had willen voorkomen; nutteloos hadden wij een standpunt prijsgegeven, dat men ons wel had willen doen innemen, doch dat wij niet zouden kunnen handhaven, als het hard tegen hard ging. Wat hadden we nu aan ons verzet gehad? Niets. $(c)$

De rol, die Engeland hier gespeeld heeft om de West-Indische koloniën machtig te worden, de comedie, gelijk ik haar reeds noemde $(d)$, is door Van Hogendorp ook niet buitengewoon fraai gevonden, waar hij toch over die bezittingen met eenige verschooning schrijft $(e)$ : "De Engelschen hadden het oog op dezelve om er ons geld voor te geven. Zij namen groote schulden van ons over, namelijk tien millioen guldens aan Zweden voor de hulp in de verovering van België, de helft in vijftig millioen guldens aan Rusland voor de zelfde hulp. Deze beide schulden betaalde Engeland voor ons en bedong Berbice voor de eerste, Demerary en Essequibo voor de tweede.

"Voor het Huis van Oranje was dit als het ware eene ruiling. Het gaf die kolonien weg voor het bezit van Belgie $\left(f^{\prime}\right)$. Voor de

(a) Zie het belangrijk rapport in Sluiting noot 59 en de daarop betrekkelijke beschouwingen op bl. $263-265$; ov. $25-27$.

(b) Zie het belangrijk rapport dd. 30 Juli 1814 in Sluiting noot 62; en bl. 265 ; ov. 27.

(c) Verg. Brieven-Hogendorp V, 511-512.

(d) Sluiting 264; ov. 26.

(e) Brieven-Hogendorp V, 512-513.

(f) Deze aanteekening van "latere jaren" is echter niet historisch juist. Van weggeven was geene quaestie. De Souvereine Vorst kòn niet anders, en verklaarde zich wel ter dege overtuigd, dat België niet mocht verkregen worden, ten koste van onze koloniën. Zie Sluiting 263 ; ov. 25. 
oude Vereenigde Nederlanden, voor Holland en Zeeland inzonderheid was het een zuiver verlies, alzoo er voor dezelve geen de minste macht over Belgie uit voortgesproten is, noch voortspruiten kon. Integendeel wij hebben daarvoor uit België ontvangen de zware regten op den koophandel en de entrepôts.

"Eer deze zaak bij een verdrag met Engeland tot stand was gekomen, vroeg mij de Prins, thans Koning, welke van de kolonien de meeste waarde voor ons had. Ik antwoordde: Suriname, omdat de plantagien daar meestal in handen van Nederlanders zijn en de meeste kapitalen oṕ de plantagien geschoten uit Nederland komen. In Demerary zijn vele Engelschen gezeten; op de nieuwe plantagien aldaar is veel geld uit Engeland geschoten, en zelfs de meerderheid van de bevolking is Engelsch.

"Inmiddels hebben wij bij het verdrag de vaart behouden op de Nederlandsche plantagien, hetwelk in de omstandigheden een blijk van edelmoedigheid aan de zijde van Engeland was.

"Doch een verwijt van het geweten der Engelsche Ministers heeft er zeker aanleiding toe gegeven. Wij zouden België hebben doen opstaan, zoo als wij zelve opgestaan waren. Dan hadden wij de verovering niet behoeven te betalen aan Rusland en Zweden. Maar Engeland heeft ons dat belet; wij hebben in den aanvang van dit werk moeten uitscheiden; wij wisten toen niet regt wat het oogmerk der Engelschen was. Nu blijkt het zonneklaar."

Elders heb ik breedvoerig beschreven, hoe het verdrag eindelijk den $13^{\mathrm{n}}$ Augustus 1814 tot stand kwam; de ergernis van Van Nagell, die zijn ontslag vroeg, zijne weigering tot medeonderteekening, zoodat alleen Fagel teekende, het juister inzicht van Falck en Fagel $(a)$. Ziehier nog hoe Van Hogendorp deze geschiedenis mededeelt $(b)$ :

"De Prins inmiddels naar Brussel vertrokken zijnde, willigde er in door de pen van Falck. De Heer van Nagell was er woedend over, en vroeg zijn ontslag dog liet zig door den Prins overhalen om te blijven. Ik beken, dat de verkoop van Berbice, Demerary en Essequebo hard was, en die van de Kaap daarentegen voordeelig $(c)$. Maar ik twijfel geenszins of het ware te Weenen erger

(a) Zie Sluiting 265 ov; vv. 27 vv.

(b) Brieven-Hogendorp V, 73.

(c) Hiervoren lazen wij, dat Van Hogendorp over het verlies der WestIndische koloniën sprekende, zegt dat wij ze hadden weggegeven; nu dat wij ze verkocht hebben, zoomede De Kaap. Noch het een, noch het ander is juist; doch men moet ook niet blijven hangen aan de letter van dergelijke huishoudelijke aanteekeningen, die zeker de steller zou gewijzigd hebben, 
gelopen, buiten en behalve het verlies van tijd. De Russische schuld en de schadevergoeding van Zweden waren ons tog reeds door de Mogendheden op den hals gelegd, en de Prins had mij al lang gevraagd, op welke W.I. kolonien wij het meest dienden te staan; waarop ik Suriname genoemd had als de meest Hollandsche. Wij behielden de vaart op de afgestane kolonien met betrekking tot de Hollandsche planters; en de menigte Engelsche planters, die de kolonien onder den oorlog met Engelsch kapitaal waren komen bewonen, konden waarlijk niet als onze oude onderdanen,' noch hunne plantagien als ons koloniaal eigendom teruggeëischt worden. Door de afschaffing van den slavenhandel is het verderf van de West-Indien te voorzien, zodat de Oost voor het vervolg schier alles is. De Oost nu kregen wij geheel terug; de ruiling van Banca tegen Cochin was ons zeer voordeelig; en naar mate van onze kragten hebben wij thans kolonien genoeg, indien wij ze wel besturen. Maar de Heer Van Nagell ziet den slavenhandel niet aan als afgeschaft, is ook zeer op dien handel gesteld en beschouwt Demerary als veel meer waard dan Java." - Reeds een jaar nadat Van Hogendorp dd. 17 Juni 1814 zijne aanteekening had gesteld omtrent het verliesgevende voor ons van de Kaap de Goede Hoop, moest hij den Souvereinen Vorst dd. 11 Augustus 1815 berichten $(a)$ : "Ik heb den heer Mulder van de Kaap bij mij gehad, een verstandig man, die vooruitgezonden was naar de Kaap toen de heer de Mist als Commissaris-Generaal derwaarts ging. Hij heeft mij verklaard, dat die Colonie dagelijks en spoedig in bloei toeneemt, dat de in- en uitgaande regten 300.000 Rijksdaalders 's jaars opbrengen, en dat de belastingen in het algemeen staan gebragt te worden op 3.000.000 Rijksd.; de gebouwen en landerijen zijn sedert 10 jaren 40 à 50 pCt. gerezen, dit alles is de vrucht van een beter bestuur, hetwelk hij zeide niet noodig te hebben om mij uit te leggen, alzoo het slechts de uitvoering was van mijn bekende ontwerpen. Ik neem de vrijheid dit verslag aan U. M. te doen, omdat er proefondervindelijk uit blijkt, waartoe kolonien kunnen gebragt worden door middel van zulke beginselen van bestuur. U. M. heeft deze beginselen aangenomen voor onze bezittingen in

als ze bij den druk onder zijne oogen waren gekomen, en bij de wetenschap welk eene beteekenis of uitlegging aan dergelijke min juiste uitdrukkingen zouden gegeven zijn. Te vergeefs b. v. zal men daarnaar zoeken in de $B \ddot{z j-}$ dragen tot de huishouding van Staat.

(a) Brieven-Hogendorp VI, 162-163. 
de drie Waerelddeelen en het is niet uit te rekenen welke de heilzame gevolgen daarvan zijn kunnen over eenige jaren, onmiddelijk voor 's Lands kas, en middelijk door de algemeene welvaart beide in de Kolonien en in het moederland."

Hoe snel zou de teleurstelling komen!

\section{III.}

\section{0vereenstemming tussehen Nederland en Engeland in 1819} ten aanzien van de wenschelijkheid het Londenseh tractaat van 13 Augustus 1814 te herzien.

Reeds vó́r en onder het sluiten van het tractaat van 1814 deelden onze staatslieden de overtuiging, dat wij aan de terugverkrijging der voormalige Nederlandsche factorijen in Vóór-Indië weinig zouden hebben. Zoo Falck, Fagel, Elout $(a)$; met hen meende ook Gijsbert Karel van Hogendorp het een goede ruil zou zijn, indien wij er voor konden verkrijgen de Engelsche bezittingen op Sumatra's Westkust met Poeloe Pinang. "De veranderde omstandigheden", schreef deze onder dagteekening van 17 Juni 1814(b), "zoo omtrent den Oost-Indischen handel in het algemeen, als in het bijzonder door de verkregen oppermagt der Engelschen over Hindostan, in Bengalen, en op de kusten van Chormandel en Malabar maken het bezetten van vestingen of bevestigde factorijen aldaar niet alleen geheel onnut maar zelfs nadeelig en kostspillig. Men zoude dus, in geval er van eenige afstanden questie moet zijn, alle die comtoires als in Bengalen, Chintchura, Cassimbaser, Patna, enz. op Chormandel, Masulipatnam, Paleacatte enz. op de Malabar, Cochin en onderhoorigheden en zelve de factory te Suratte, als voorwerpen van onderhandeling kunnen aanbieden, om daarvoor eenige andere bezittingen of wel voorwerpen of voordeelen van anderen aart in vergoeding te verkrijgen.

"Mogelijk konde men met de Engelschen tot eene liberale soort van schikking of overeenkomst komen. Om namelijk, wanneer men van alle bezittingen in de West van Indië, en vooral die in hunne bezittingen geënclaveerd, afstand deed en zich verpligtte om benoorden en bewesten of buiten de Straten van Malacca en Sunda

(a) Zie Factorijen II in de hoofdstukken XXI en XXII het oordeel dier staatslieden.

(b) Brieven-Hogendorp VI, 508. 
geene etablissementen te behouden of te maken; als dan de Engelschen zich wederzijds ook wilden verpligten bezuiden en beoosten of wel binnen die zelfde straten van Malacca en Sunda geen etablissementen zullen behouden of aanleggen.

"Ten vervolge hiervan zouden de Engelschen onze kleine bezettingen op de Westkust van Sumatra, namentlijk Padang, Poelo Nias en onderhoorigheden, die zij reeds sedert lang op ons veroverd hebben, behouden, maar ook daarentegen hun etablissement op Poeloe-Pinang of Prince of Wales Island, aan ons moeten overgeven.

"Op deze wijze zoude men alle moeijelijkheden en oorzaken tot verschil in Oost-Indie uit den weg geruimd, en als 't ware onmogelijk gemaakt hebben. Omtrent den handel op onze wederzijdsche bezittingen zoude men mede eene overeenkomst kunnen maken, op den liberalen grond van aan hen in onze bezittingen dezelfde voorregten en vrijheden toe te staan, die zij aan ons in de hunne vergunnen. "Onze bezittingen in de groote Oost, zoo als men die noemt, zouden alsdan in een sterk verbond, het rijke eiland Java als hoofdbezitting beschouwd, gebragt en ligtelijk bestierd en verdedigd kunnen worden. De Engelsche vlag vriendschappelijk vereenigd met de onze, zoude aan onze beide natien de opperheerschappij van zeevaart en handel in Oost-Indien verzekeren, en daarvoor aan ons Vaderland de gelegenheid bezorgen en verzekeren om van die onwaardeerbare overzeesche bezittingen en den handel op dezelve alle die voordeelen te trekken, die dezelve onder een goed bestuur en den zegen des Allerhoogsten in zoo ruime mate in staat zijn op te leveren."

Als Gijsbert Karel zich laat hooren, verdient hij altijd aangehoord te worden, doch dit wil niet zeggen dat men hem altijd bewonderen moet. Gelukkig was zeer zeker de gedachte om reeds bij het weldra te sluiten tractaat van 1814 de ruiling der Hindostansche factorijen op te werpen; het blijkt echter niet, dat dit geschied is; daarentegen zou het een enorm slechte zet geweest zijn, wanneer wij overeenkomstig dit advies gansch Sumatra's Westkust hadden prijsgegeven, om met Poeloe Pinang te worden afgescheept.

De Hindostansche factorijen daalden voor ons nog meer in waarde, toen na de overneming bleek, dat van Britsch-Indische zijde al het mogelijke werd gedaan, om ons er het bestaan naar waarheid onmogelijk te maken, gelijk ik dit elders breedvoerig heb beschreven $(a)$.

(a) Zie Factorijen I en II. - Ook uit deze geschiedenis blijkt, dat Engeland slechts vrijzinnig optrad, als het er toch niet voor zijne belangen op aankwam, en uit dit oogpunt is onwaar wat Chamberlain dd. 18 Januari 1898 te Liverpool 
Vandaar de gedachte, dat wanneer wij deze factorijen andermaal in Engelands bezit stelden en daarvoor de Britsche bezittingen op Sumatra kregen, waar immers de Engelschen tegen het Nederlandsch gezag intrigeerden, wij dan in Vóór-Indië van lastposten werden ontslagen, daarentegen op Sumatra van onruststokende en twistzoekende naburen. De regeering in Nederland droeg dientengevolge tegen het einde van 1818 ambassadeur Fagel op, om lord Castlereagh over eene herziening van het tractaat van 1814 te onderhouden en wel in den geest, dat de Hindostansche bezittingen zouden geruild worden tegen de Britsche op Sumatra met Poeloe-Pinang. Fagel, de ontvangst der lastgeving erkennende, waarschuwde aanstonds, dat de Engelschen zeker Poeloe-Pinang niet zouden opgeven, en dat wij onze rechten op Billiton niet zouden erkend krijgen, zonder afstand onzerzijds van Malakka $(a)$. De samenkomsten, die daarna de ambassadeur met den Britschen minister had, droegen een alleszins welwillend karakter, en zoo ook verklaarde Castlereagh bij eene ontmoeting op den $19^{\text {n }}$ Maart 1819 zich alleszins bereid tot eene herziening van het koloniaal bezit mede te werken, er echter voorloopig in verhinderd te wezen door overmaat van werkzaamheden $(b)$.

Terwijl men nu onzerzijds in afwachting verkeerde, vervoegde zich de Engelsche gezant bij ons hof, lord Clancarty, medio Augustus 1819 bij Buitenlandsche Zaken; onze Regeering was destijds te Brussel gevestigd. Hij deelde aan minister Van Nagell mede, dat lord Wellington, die mede te Brussel vertoefd had, en lid van het

met gewone jingo-pocherij redevoerde: „We alone are not only the earliest in the field, but have been from the first the pioneers of an universal trade. Wherever we have conquered, we have conquered for civilisation and for the world; and we have never attempted to put up barriers against the other peoples. But that is not the policy of our neighbours, of our rivals and our friends...." $O$ p bl. $811-812$ van het op bl. 52 sub $d$ vermeld artikel.

(a) Zie de bijzonderheden in Factorïen II, hoofdstukken XXII en XXIV.

(b) Zie de bijzonderheden in Factorijen II, hoofdstuk XXV, zoomede Singapore II $331-335$; ov. 19-23. - Ten eenenmale onjuist is de voorstelling van onwelwillendheid bij Smulders 37: „Maanden lang deed Fagel vruchtelooze moeite bij lord Castlereagh. Men moest, zeide deze, in Holland tevreden zijn met de openbare afkèuring (désaveu) van de verrigtingen van Raffles." Door Castlereagh was, gelijk door mij medegedeeld, geantwoord dat hij op het oogenblik geen tijd kon vinden voor de onderhandelingen; Fagel had dit ook ten volle ingezien, maar de vrees niet kunnen onderdrukken, dat Raffles intusschen zou voortgaan, waarop de minister hem geruststellend antwoordde, dat daarvoor geene reden bestond wegens de afkeuring, die Raffles bereids was geworden. Zie Fagel's rapport met het désaveu formel in Opvattingen 413 ; ov. 73. 
Britsche kabinet was, met bezorgdheid had gesproken over Raffles' optreden en de daaruit voortvloeiende oneenigheden in Indië, waarom het ministerie zeer op prijs stelde ten volle over de quaestiën te worden onderricht. Op Van Nagell's voorstel dd. 12 Augustus machtigde toen de Koning den $14^{\mathrm{n}}$ minister Falck om den Engelschen gezant in te lichten (a). Maar vier dagen later stond de zaak ernstiger. Te Londen waren de klachten der Britsch-Indische regeering ingekomen tegen onze zucht om ten koste van Engeland, zich van den Oosterschen handel bij uitsluiting meester te maken en was daarmede de nu in Europa bekend wordende bezetting van Singapore verdedigd geworden (b). Clancarty had de stukken hierover uit Londen ontvangen en in last gekregen om er Buitenlandsche Zaken over te onderhouden, waartoe hij den $18^{\mathrm{n}}$ Augustus zich andermaal bij Van Nagell vervoegde en wellicht als gevolg hiervan nog dien $18^{\mathrm{n}}$ onzen minister zond een overzicht van de uit Britsch-Indië ontvangen berichten; hij voegde er de verwachting bij, dat deze openhartige manier van behandeling aan een gelukkig einde der voorgenomen onderhandelingen zou ten goede komen $(c)$. Onder den indruk van dit alles haastte zich Van Nagell om ook dien $18^{\mathrm{n}}$ er bij collega Falck op aan te dringen, dat Clancarty toch goed werd ingelicht $(d)$. De departementschef van Koloniën zal natuurlijk daartoe zijn best hebben gedaan $(e)$; nochtans een afdoend resultaat schijnt dit niet te hebben gehad. In elk geval de besprekingen werden door een onder dagteekening van 20 Augustus aangeboden Memorandum van Clancarty geopend, waardoor wij nu gelegenheid kregen de beweerde grieven gezet te wederleggen $(f)$. Het stuk was persoonlijk door den ambassadeur op

(a) Zie de stukken van 12 en 14 Augustus in Singapore II 337, ov. 25, noten $a$ en $b$.

(b) Zie over deze stukken Singapore II 335-336; ov. 23-24.

(c) Zie het briefje in noot $a$, bl. 338 Singapore II; ov. 26.

(d) Zie het briefje in noot $d$, bl. 337 Singapore II; ov. 25.

(e) Zie over het gesprokene nader Singapore II $339-340$; ov. 27-28.

(f) Smulders zegt ten onrechte zoowel op bl 38 als op bl. 47 , dat het Memorandum van,den $18^{\mathrm{n}}$ was; schrijvende in verband met het feit, dat de bezetting van Singapore toen juist in Europa was bekend geworden: „Lord Clancarty had namelijk bij eene nota van 18 Aug. 1819 als conditio sine qua non der onderhandelingen gesteld, dat Engeland niet aan onze Regering den sleutel van de vaart naar China zoude afstaan, nadat hij vroeger onze regten op Singapore had pogen weg te cijferen, maar Falck hem weldra door het toezenden van het verdrag van 1784 met den Sultan van Djohor van zijne dwaling overtuigd had."

Dat vroeger zal wellicht juist zijn de door Van Nagell gewilde conferentie 
Buitenlandsche Zaken gebracht en zal wel, denk ik, opgesteld zijn na er eerst met Van Nagell over te hebben gesproken; het moest dienen, als het ware, voor een uitgangspunt van de weldra aan te vangen onderhandelingen $(a)$.

De minister zond het belangrijke stuk aan collega Falck, ten einde, overeenkomstig 's Konings verlangen, de adviezen der beide ministers aan den Vorst te kunnen overleggen (b).

Het resultaat der overwegingen was de belangrijke voor Clancarty bestemde contra-memorie der Nederlandsche regeering van 31 Augustus $1819(c)$.

Toen dit stuk gereed was, had de Britsche gezant eene reis naar Engeland ondernomen. Van Nagell zond dientengevolge niet alleen afschriften der memoriën aan onzen ambassadeur te Londen, maar tevens het voor Clancarty bestemde stuk, met verzoek dat het pakket door Castlereagh zou opengemaakt worden, opdat deze evenzeer van de contra-memorie kennis zou nemen; de brief drukt tevens bezorgdheid uit over den loop, dien de onderhandelingen zouden nemen, nu Raffles bleek te overwinnen $(d)$.

Fagel, oorspronkelijk vervuld met de beste verwachtingen voor den uitslag der onderhandelingen, zóó dat hij zich als eenigen Nederlandschen onderhandelaar voldoende achtte $(e)$, ontving den $30^{\mathrm{n}}$ onver-

van den $18^{\mathrm{n}}$. Over het verdrag van 1784, zie Malakka-Riouw 21-22 en Singapore I 403 ; ov. 15. - In Opvattingen 544, ov. 156, sub 69 , is de drukfout van 21 Augustus voor Clancarty's memorandum gemaakt. - Over den inhoud der Memorie en de critiek er op, zie Singapore II $341-346$; ov. 29-34.

(a) Onjuist is de voorstelling bij Smulders 37, waar de Schrijver over Castlereagh's weerzin de onderhandelingen te beginnen, op de zinsnede aangehaald hiervoren in noot $b$ bl. 43 laat volgen: „Eensklaps echter hield de onverschilligheid van den Britschen Staatsman op, daar hij, waarschijnlijk ten gevolge van het ontvangen van vertoogen dienaangaande uit Bengalen, nu zelf aan Fagel de hooge noodzakelijkheid betuigde van het regelen der Indische zaken." - Castlereagh had nooit voor Fagel's aandrang onverschilligheid betoond, zoodat die ook niet eensklaps kon ophouden. Het was ook nu niet Castlereagh, die aan Fagel zijne wenschen ten aanzien van het openen der onderhandelingen te kennen gaf, doch de Britsche minister gelastte Clancarty er bij ons Buitenlandsche Zaken over te spreken. Trouwens de eigen aanhalingen van Smulders, die daarop volgen uit Castlereagh's Correspondentie bewijzen, dat de zaak naar Nederland was verlegd. Smulders heeft echter die brieven medegedeeld, zonder juist te weten, waarover ze loopen.

(b) Zie Van Nagell's verzoek aan Fagel in noot $a$ bl. 347 Singapore II; ov. 35.

(c) Zie over den inhoud van dit stuk Singapore II $347-348$; ov. $35-36$.

(d) Zie het schrijven aan Fagel in Singapore II noot $d$ bl. 346 ; ov. 34 .

(e) Zie zijn schrijven van 30 Augustus aan Van Nagell in Singapore II 348 ; ov. 36 . 
wacht een bezoek van Clancarty, waarop de Indische zaken nader breedvoerig werden besproken $(a)$. Het $\operatorname{den} 6^{\mathrm{n}}$ September ontvangen pakket van Van Nagell deed hem echter nu ook in den loop der onderhandelingen een zwaarder hoofd krijgen, zoodat hij om den heer Falck als tweeden onderhandelaar vroeg. Daartoe schreef hij den $7^{\mathrm{n}}$ September aan Van Nagell, onder mededeeling, dat als Britsche gevolmachtigden zouden aangewezen worden de heeren Castlereagh en Canning $(b)$. Den $8^{\text {n }}$ zond Castlereagh de door Fagel gezonden stukken, waarbij ook Van Nagell's scherp oordeel over Raffles was, aan den ambassadeur terug, met een welwillend schijven, waarin hij verklaarde gaarne van Van Nagell's verzekering acte te nemen, omtrent de verklaarde bereidwilligheid elkander te verstaan, waarvan hij de beste verwachtingen zeide te koesteren $(c)$.

IV.

\section{Werkzaamheid van den oud-commissaris-generaal Elout ter voorbereiding van de in November 1819 te Londen aan te vangen onderhandelingen.}

De onderhandelingen zouden te Londen in November 1819 aanvangen $(d)$. Van onze zijde moest als gevolmachtigde optreden ambassadeur Fagel, terwijl deze als mede-gevolmachtigde nog aanbeval, gelijk ik mededeelde, den heer Falck (e). Deze aanbeveling was echter zonder succes. De Oostenrijksche regeering, geleid door den minister Metternich, had te Weenen andermaal bijeengeroepen de deelhebbers van het vorige, aldaar gehouden groote congres ten einde de Karlsbader besluiten van Augustus 1819 te doen sanctionneeren, waarbij de beginselen der omwenteling, in de kleinere Duitsche staten ontkiemd, werden gefnuikt en daartoe de bevoegdheden van enkele Duitsche vorsten beperkt, met name die om grondwetten in te voeren. Ook Nederland werd tot dit congres uitgenoodigd; veel belang hadden wij er niet bij, en zoo zou zeer wel een tweederangs-diplomaat er hebben kunnen volstaan. Koning Willem I verlangde echter, dat zijn minister van Koloniën,

(a) Singapore II 349 ; ov. 37 .

(b) Singapore II 350-351; ov. 38-39.

(c) Singapore II 349-350; ov. 37-38.

(d) Singapore II 347 ; ov. 35.

(e) Singapore II 351 ; ov. 39. 
Mr. Falck, er heen ging en deze had er zich slechts aan te onderwerpen. Toch zou ook dit geen beletsel behoeven te zijn, dat hij als gevolmachtigde te Londen optrad, want het congres heeft geduurd van 19 November tot 20 Mei 1819, terwijl de onderhandelingen te Londen eerst zijn aangevangen in Juli 1820 ; maar dit wist men in November niet; bovendien stelde de Koning er nu weer prijs op, dat aan het hoofd van het departement van Koloniën een kundig man werkzaam bleef, juist in den tijd, dat de onderhandelingen zouden plaats vinden $(a)$. Het gevolg was, dat de Regeering voor de Londensche zending het oog liet vallen op een staatsdienaar, die bovendien door plaatselijke ervaring geheel op de hoogte van de zaken kon geacht worden, namelijk Elout.

Reeds bij de besprekingen te 's-Gravenhage met Clancarty in midden Augustus had men hem nevens Fagel genoemd; er bestond evenwel destijds onzekerheid of hij wellicht niet op de rampspoedige reis met de Evertsen vergaan zou zijn (b). Hij kwam nochtans in den aanvang van October 1819 behouden te Londen aan, een omweg, door dit ongeluk noodzakelijk geworden, dat nu echter zijne goede zijde had. De gewezen commissaris-generaal verbleef er toch eene week, waarin hij zoowel op Fagel als op de Britsche staatslieden den besten indruk maakte. De stroefheid, die door de uit Britsch-Indië overgebriefde reputatie, Elout's bezoeken, naar men zou verwachten, moesten opwekken, had voor groote waardeering plaats gemaakt; de appearance of frankness, de show of fairness, waarover lord Moira zich in een brief van 1 Maart 1821 zoo schamper zou uitlaten $(c)$, misten hare uitwerking niet. Herhaaldelijk ontmoetten Fagel en Elout elkander, bekenden trouwens van ouds, en ook deze nadere samenkomsten hadden den gezant geheel ingenomen. Er was mede een beleefdheidsbezoek aan Castlereagh

(a) Onjuist is het dus bij Smulders 38, dat de onderhandelingen werden uitgesteld voor Falck, omdat men er aan hecktte: „dezen uitstekenden Staatsman, wegens zijne veelomvattende kunde, niet het minst in onze koloniale belangen, als Gevolmagtigde te zien optreden".

(b) nM. de Falck, in my conversation with him, seemed to feel the propriety of not mixing more of Indian knowledge than was absolutely necessary in the projected negociation, professing himself to deprecate the larger and more essential interests of the two countries being in any wise influenced by local considerations: they will probably, therefore, have one Indian only (not improbable Elout, if he is not drowned) to join Fagel in the negociation."

Clancarty aan Castlereagh dd. 20 Augustus 1819. Corr. 137.

(c) Elout 237 ; ov. 9. Zie ook hierna de bijl. 8. 
gebracht. Ofschoon er niet over zaken werd gehandeld, was het ijs er door gebroken.

Onder deze aangename wederzijdsche indrukken begaf Elout zich den $8^{\text {n }}$ October naar 's-Gravenhage. Met dezelfde mail richtte Fagel een brief aan Buitenlandsche Zaken. Van de mogelijke bezwaren tegen Falck's overkomst vernomen hebbende, wees de ambassadeur op Elout als den aangewezen persoon, ook in weerwil van hetgeen, herinnerde de brief, hieromtrent indertijd te Brussel aan Van Nagell was opgemerkt $(a)$. Eenige dagen later schreef Fagel Elout zelf. Lord Amherst, eerlang, naar nog zal vermeld worden, bestemd om Moira als landvoogd te vervangen $(b)$, was tijdens het bestuur van commissarissen-generaal in eene diplomatieke zending naar China geweest en op zijne terugreis als schipbreukeling te Batavia, evenals zijne lotgenooten, welwillend ontvangen. Zoo men ons de betoonde gastvrijheid met smaadredenen loonde $(c)$, Amherst zelf toonde de ondervonden vriendschap wel zich te willen herinneren, zoodra Elout, onder dezelfde noodlottige omstandigheden, te Londen bleek aangekomen; vandaar dat hij door Fagel's tusschenkomst den hoogen schipbreukeling ten zijnent noodigde. De ambassadeur moest evenwel antwoorden, dat Elout reeds naar Holland op reis was, doch voegde er aan toe, dat deze vermoedelijk spoedig in de gelegenheid zou zijn, om de uitnoodiging aan te nemen. Bij brief nu van 14 October 1819 gaf Fagel van de correspondentie kennis aan Elout; dezen werd medegedeeld, dat het blijkbaar lord Amherst bijzonder aangenaam zou zijn hem te ontvangen, waarna in zonderlingen stijl het schrijven aldus besloot: "Ik kan de eer hebben,

(a) "Cette poste vous recevrez Mr. Elout qui a passé une semaine ici et avec lequel j'ai été charmé de renouveller connaissance. Je l'ai mis amplement au fait de l'état actuel de nos discussions avec ce Gouvernement-ci sur les affaires de l'Inde, et j'ai été fort content de nos conversations là-dessus. Celle que nous avons eue ce matin avec lord Castlereagh a été une d'introduction et de politesse plutôt que d'affaires proprement dites. Cependant il a été question aussi de celles-ci et je me flatte que ces Messieurs ont été mutuellement satisfaits. Je vous avoue franchement que si (comme je le prévois) les occupations de Mr. Falck sont un obstacle à ce qu'il vienne ici au mois de Novembre, je souhaiterais bien que le choix du Roi tombât sur Mr. Elout, et je crois que nonobstant de ce que je vous disais là-dessus à Bruxelles on s'en accomodera fort bien ici." (B. Z.)

(b) In Benkoelen 285, ov. 3, wordt hij door eene drukfout Amhurst genoemd.

(c) „Ellis, door wien een dagverhaal van de ambassade werd in het licht gegeven, vergeet niet enkel te vermelden de gastvrijheid en hulpvaardigheid van Batavia's ingezetenen, door hen in zoo ruime mate genoten, maar hoont hen met zwarte ondankbaarheid." Lauts VI 67. 
UHEd.Gestr. te verzekeren, dat het mij tot groot genoegen gestrekt heeft Uw HEd.Gestr. eenige dagen hier te bezitten, en dat het mij zeer zoude verheugen Dezelven binnen kort herwaarts te zien retourneeren, waartoe ik de hoope niet opgeeve, ofschoon ik verneem, dat men ten Uwent verlangende is U HEd.Gestr. tot President van de Tweede Kamer verkozen te hebben" $(a)$.

Althans was Elout door de Staten van Holland het lidmaatschap dier Kamer opgedragen, doch de benoeming werd door hem niet aangenomen (b). Voorloopig ving hij aan met werkzaamheden ten behoeve van het departement van Koloniën; want ook al ware men in Holland niet vervuld geweest met het stellige voornemen om Engeland territoriale ruilingen in Oost-Indië aan te bieden, waartoe Elout's hulp onontbeerlijk werd geacht, toch zou men deze hebben ingeroepen voor de uitvoering van de Bataviasche conventie van 24. Juni 1817. Die overeenkomst was een uitvloeisel geweest van art. 8 der Bataviasche verbintenis dd. 23 Juli 1816, waarbij Java en Makasser aan Commissarissen-Generaal waren overgegeven $(c)$. Velerlei financieele geschilpunten waren namelijk bij de overgave onbeslist gebleven en tot eene nadere overeenkomst uitgesteld, ten einde de teruggave der bezittingen te bespoedigen. Het verdrag van 24 Juni 1817 beoogde de nadere regeling; doch zij was eene, waarbij alsnog vele punten aan het oordeel der regeeringen in Europa werden overgelaten, waaronder deze twee soorten van wederzijdsche vorderingen:

$1^{0}$ die, tegen wier erkenning, wat de schuldoorzaak betrof, geen bezwaar werd gemaakt, doch over wier juist bedrag men het niet eens had kunnen worden;

$2^{\circ}$ die, waaromtrent de schuld in beginsel ontkend werd. $(d)$

Uit de naar Nederland gezonden bewijsstukken bleek nu wel, dat wij, volgens de uiteenzetting van Commissarissen-Generaal, eene aanzienlijke som hadden te vorderen, doch onze eerste departementschef voor de Koloniën, staatsraad Goldberg, bracht in een schrijven dd. 11 April 1818 onder 's Konings aandacht: "den wensch door den heer Elout geuit over het niet te spoedig afdoen der likwidatie met het Britsche Gouvernement over de wederzijdsche pretensiën, ten

(a) Bïjdr. E. 59.

(b) Bl. II van de Inleiding der Bijdr. E. van 1851.

(c) Zie over die conventie van 1816 Opvattingen $363-365$; ov. 23-25. Het verdrag in het Engelsch bij Hoek; in het Nederlandsch bij Norman.

(d) Over de houding onzer Commissarissen-Generaal ten aanzien dier geldelijke quaestiën, zie Elout 239-242; ov. 11-14.

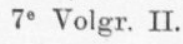


einde den heer Elout zelve en welligt ook Baner $(a)$ in de gelegenheid mogen zijn, de nog vereischt wordende ophelderingen te geven". In overeenstemming hiermede vonden de ministers van Buitenlandsche Zaken en van Financiën, blijkens hun collectief advies van 16 April 1818, het ook maar beter zich voorloopig in dat wespennest niet te steken; dus, wanneer althans Engeland niet aandrong, op Elout's terugkomst te wachten $(b)$. Vandaar, dat het Koninklijk besluit dd. 17 April 1818 bepaalde: "dat in afwachting van de terugkomst van Onzen commissaris-generaal Elout aan de dezerzijds ten laste van het Britsche Gouvernement te sustineren pretensiën, geen verder gevolg worde gegeven". Zoo was reeds op Elout's kennis beslag gelegd in Europa, een jaar vò̀r hij aldaar aankwam.

Zijn persoonlijk optreden werd nu nog dringender noodig, nadat met de jammerlijke schipbreuk van de Evertsen, de kostbaarste schriftelijke gegevens in den schoot der golven waren bedolven. $\mathrm{Om}$ aan dit diep teleurstellend gemis eenigszins tegemoet te komen, had reeds Elout bij het voortzetten zijner reis na het ongeluk, eene breede memorie uit zijn geheugen aan boord opgesteld over den staat, waarin hij Nederlandsch-Indië had verlaten en de gebeurtenissen, die onder de Commissie-Generaal waren voorgevallen $(c)$. Daarna in Holland teruggekomen, beijverde hij zich om met behulp der op het ministerie voorkomende stukken, en in afwachting der uit Batavia-andermaal ontbodene, aan minister Falck de gegevens te verstrekken, die het aanvangen der onderhandelingen op eene breedere basis dan het Koninklijk besluit van 17 April 1818 beoogde, mogelijk kon maken. Een belangrijk stuk van November 1819, houdende Consideratiën nopens de afdoening der geschillen tusschen

(a) Die in comptabele betrekking de Indische regeering had bijgestaan. Zie over hem Van de Graaff I \& 25.

(b) „Immers bij de examinatie van hetzelve en van de bijlagen daartoe behoorende is het hun voorgekomen dat het een noch het anderen geen genoegzame inlichtingen bevatten om de onderhandelingen over de onverevend geblevene zeer belangrijke vorderingen, die schijnbaar in 't voordeel van de Nederlanden zouden moeten afloopen te entameeren en met hoop op eene goede uitslag voort te zetten, en dat zoo lang van de zijde van Engeland op geene afdoening wordt geinsisteerd, het dezerzijds meest raadzaam zal wezen de terugkomst van den $\mathrm{Hr}$. Commissaris-Generaal Elout af te wachten, als welke meer dan iemand anders geschikt schijnt om door Z. M. tot het aanvangen en ten einde brengen der definitieve liquidatie te worden gemachtigd." (B. Z.)

(c) Opgenomen in de Bijdr. E. van 1851, bl. $10 \mathrm{vv}$. 
Groot-Brittannië en de Nederlanden was er o. a. de vrucht van $(a)$.

Te midden dezer werkzaamheden, ontving Koloniën een brief dd. 19 October 1819 van Buitenlandsche Zaken met de dubbele vraag om, wegens de in November aan te vangen onderhandelingen, eene instructie ten behoeve der gevolmachtigden te ontwerpen; en verder of Elout niet de geschiktste persoon zou zijn voor het optreden als mede-onderhandelaar $(b)$. Het antwoord dd. 23 October 1819 was zooals zich uit de reeds bestaande samenwerking liet verwachten. Ook Falck en Elout waren van ouds vrienden. Niemand meer dan gene had de benoeming van deze tot commissaris-generaal toegejuicht, doch tevens zijn heengaan naar Indië destijds zeer betreurd. "Als vriend en als mensch is Elout niet te remplaceren", berichtte Falck in een brief dd. 3 October 1814 aan zijn vriend D. J. van Lennep $(c)$; en deze gunstige meening was onverzwakt gebleven. De niet te remplaceeren werd nu "de eenige mogelijke", en wel, schreef de minister aan zijn ambtgenoot, uithoofde van het volslagen verlies der papieren met de Evertsen. "Zijne grondige kennis van den staat der zaken in die gewesten", voegde Falck er aan toe, "gevoegd bij zijne beproefde bekwaamheid en ondervinding, maakt die keuze ten hoogste doelmatig" (d).

Met den aanvang van November 1819 kon de minister van Koloniën aan zijn ambtgenoot van Buitenlandsche Zaken berichten, dat de instructie zoo goed als gereed was. Falck wilde er echter met dezen over spreken, en daar zijne onderdanen wegens podagra weerbarstig waren, "zooals wel meer onderdanen in onzen tijd", verzocht hij Van Nagell spoedshalve bij hem te komen (e). De minister

(a) Opgenomen in Bijdr. E. 1-59; bij De Sturler een overzicht er van: $206-208$.

(b) Zie bijl. 1.

(c) Falck's Brieven $212 \mathrm{~N}^{\circ} 107$.

(d) Falck's Ambtsbrieven $127 \mathrm{~N}^{\circ} 7$.

(e)

Amicissime

Mijne onderdanen zijn nog steeds, zooals wel meer onderdańen in onzen tijd, weerbarstig. Maar het hoofd is weder vrij en ik geloof mij niet aan eenige teleurstelling te zullen exponeren met $\mathrm{u}$ te verzoeken van mij morgen een uurtje te gunnen, ten einde over de punten van instructie te spreken, welke îk onderstel, dat thans wel door Z. M. zullen gearresteerd zijn. Tusschen twaalf en vier uren zal ik u hier tot uwen dienst zijn en vraag, bij voorraad, excuus voor de ziekenkamer.

tt

Donderdag

A. R. FALCK."

4 Nov. 1819.

(B. Z.) 
voldeed aan deze uitnoodiging; doch de haast bleek niet noodig; men zou nog een half jaar geduld moeten hebben.

Men had derhalve ruim tijd de stukken te overwegen. Dit geeft ook ons gelegenheid om eenige meerdere aandacht te schenken aan Elout's Consideratiën, bevattende eene heldere uiteenzetting van de geldelijke en staatkundige geschillen, zoodat ze als eene toelichting op de instructie, waaruit deze was voortgevloeid, konden beschouwd worden.

De uiteenzetting had twee belangrijke staatsstukken ten grondslag, namelijk: de hiervoren vermelde conventie van 27 Juni 1817 en Clancarty's memorandum dd. 20 Augustus 1819, waarin hij de grieven zijner regeering tegen ons streven naar oppermacht in OostIndië had uiteengezet $(a)$. Elout behandelde eerst de geldelijke punten, waaronder ook de ontzegging der vroeger genoten voorrechten in Vóór-Indië (b). Vervolgens kwamen de staatkundige geschillen ter sprake, die de rapporteur wenschte te zien weggenomen, door onze bezittingen in Hindostan ter ruiling aan te bieden voor de Engelsche factorijen op Sumatra's Westkust $(c)$. Daarna wees de adviseur op het onwenschelijke om, overeenkomstig het Engelsch memorandum, onze rechten op de bezittingen van hetgeen wij Nederlandsch-Indië noemden te beschrijven, zoomede om af te zien van Singapore; ook bracht hij in herinnering, dat wel verre wij gegronde klachten tot monopoliegeest en uitsluiting gaven, Raffles en zijne handlangers steeds contracten van uitsluiting aangingen en de Engelschen in hunne koloniën veel meer monopolie-geest vertoonden $(d)$. Het bezit der sleutels op de straten van Soenda en Malakka, waarover mede Clancarty had gesproken, noemde Elout een Britsch voorwendsel om Singapore te kunnen behouden. Tegen het aanstellen van vreemde handelsagenten als consuls, gelijk ook van Engelsche zijde aanbevolen

(a) Zie breeder Singapore II 341; ov. 29.

(b) Zie Elout's beschouwingen over de waarde der voorrechten Factorijen II, $414-447$; ov. $160-163$.

(c) Zie Factorïen II 447-450; ov. 163-166.

(d) "The development of nationalism, whilst not without its good features, has also encouraged a spurious kind of patriotism, which seeks its own advantage in the misfortunes of its neighbours, and thinks it has gained little unless it is taken from them. This spirit shows itself in many forms. A few years ago its war-cry was Protection - a cry which has been successful abroad, and which, under the absurd title of Fair Trade, has been noisy and troublesome at home." Lord Farrar. Does trade follow the flag? The Contemporary Review. December 1898 bl. 810 . 
was geworden, zou de rapporteur in beginsel geen bezwaar hebben, doch op grond der ervaring met de ruziemakers, waarmede wij te doen hadden gehad, meende hij het te moeten ontraden $(a)$. Het breede stuk besloot aldus:

„Derhalve :

de cessie van de bezittingen op de vaste kusten van Indië, van onze züde; de cessie van Benkoelen aan de Engelsche zÿde;

het vredig bezit van onze ons sedert onheugelijke tijden toekomende betrekkingen met de vorsten van den Indischen archipel;

de ondubbelzinnigste en stelligste verbindlenissen nopens vrïe vaart en handel; gelijkheid van regten, zoo mogelijk met alle bezittingen in den Indischen archipel, behalve de Molukkos, immers met modificatie in de Molukkos;

eene billijke schadeloosstelling voor de finantiële regten van de amphioen, salpeter, paarlvisscherï enz.;

eene billïke schikking omtrent de finantiële verschilpunten op Java.

Zie daar de «outlines» van eene naar mijn oordeel billijke overeenkomst.

Dan, het zal in alle gevallen voorzigtig zijn te vernemen, wat eigenlijk het plan van het Britsch ministerie is, en tevens of daarbij even goede of betere schikkingen worden voorgeslagen, en in hoe verre deze door de onze, dan wel de onze door de hunne kunnen gewijzigd worden."

Wij zouden dus voor de door ons waardeloos geachte bezittingen

(a) Verg. Singapore II 351; ov. 39. Reeds bij brieven van 22 Februari en 2 Maart 1818 had onze departementschef van Koloniën, ten gevolge van de overwegingen des Britschen ministers van Buitenlandsche Zaken, het bestuur te Batavia om inlichting gevraagd. Door Commissarissen-Generaal was daarop het advies verzocht van de toenmalige handelsvereeniging aldaar, de Bataviasche Beurs, en deze had bij haar schrijven dd. 29 December 1818 geantwoord, "dat zij het aanzijn van vreemde consuls in deze kolonie niet alleen nutteloos, maar zelfs schadelijk voor den handel beschouwde". Hiermede in overeenstemming, overwogen C. C. G. G. in hunne vergadering van 31 December 1818: "dat de redeneringen in dit berigt voorkomende, ten volle overeenkomen met de gevoelens van deze vergadering", waarom zij besloten het Opperbestuur te kennen te geven: „Dat Commissarissen-Generaal zich stellig tegen het toelaten van vreemde consuls of commercieele agenten hier in Indië moeten verklaren". - Treffend schrijft Raoul de Cisternes op bl. 93 van zijn werk Le duc de Richelieu: "La politique de l'Angleterre a toujours été et sera probablement toujours contraire aux intérêts des puissances continentales, parce que cette nation tire des avantages de tous les événements qui nuisent aux autres peuples et, lorsqu'il n'arrive rien de fâcheux à ceux avec qui elle est censée vivre en paix, les émissaires qu'elle entretient sur les différentes parties du globe mettent tout en oeuvre pour faire naitre des occasions de troubles dont elle espère tirer profit. Sa puissance et sa richesse ne sont édifiées que sur des ruines." 
in Vóór-Indië krijgen Benkoelen; Singapore als strijdig met "het vredig bezit" diende Engeland los te laten; dat dit ons recht op Billiton niet erkende, werd voorbij gezien; verder zou edelmoedig Albion ons dienen te schenken eene geldsom voor onze aan VóórIndië verbonden rechten, die wij door den afstand verloren; eindelijk eene geldsom voor onze Java-vorderingen!

Dit was de proeve van welgezindheid, die wij behoorden te geven; of neen, wij moesten eerst Engeland uit den hoek laten komen. Men k kon niet weten, of dit niet nog iets beters aan de hand deed....

V.

\section{Van Nagell's toorn.}

Inmiddels was op 's Konings uitdrukkelijk verlangen, minister Falck "met weerzin", gelijk hij dd. 18 December 1819 aan zijn vriend Fabius schreef $(a)$, naar Weenen getogen. Elout's aanwezigheid op het departement van Koloniën werd dientengevolge dubbel noodig geacht, waarom minister Van Nagell wilde voorkomen, dat de oudcommissaris-generaal vroeger dan noodig zou blijken naar Londen vertrok, in het belang der onderhandelingen, die immers volgens afspraak, in November 1819 zouden geopend worden. Vandaar, dat hij bij brief dd. 9 November aan Fagel mededeelde, dat Elout voor mede-gevolmachtigde was aangewezen en bericht verzocht, of de Engelsche heeren wel gereed waren $(b)$. De ambassadeur had echter reeds vóór de ontvangst van deze depêche bij Castlereagh geïnformeerd over de gelegenheid tot het beginnen der besprekingen, zoodat zijn bericht hierover dd. 12 November zich met Van Nagell's depêche kruiste. Het bleek, dat Canning niet ter plaatse was en dat diens mede-gevolmachtigde in November zó weinig tijd zou hebben wegens de parlementaire drukten, dat een ander tijdstip

(a) Falck's Brieven 246 No 136.

(b) „J'ai l'honneur de faire part à V. E. que le roi a désigné $\mathrm{Mr}$. le conseiller d'État Elout, pour négocier conjointement avec Elle les arrangements ultérieurs pour nos relations aux Indes Orientales. Il sera prêt pour se rendre à Londres, du moment où j'apprendrai que lord Castlereagh et monsieur Canning désirent de commencer la négociation. - Entre temps la présence de $\mathrm{mr}$. Elout est assez essentielle ici pour ne pas le faire attendre à Londres le moment opportun pour entamer la besogne. V. E. voudra done avoir la complaisance de m'imformer de ce que les Min. Brittanniques décideront." (B. Z.) 
niet eens nog viel te bepalen $(a)$ ! Men kan niet anders zeggen, dan dat dit eene bijzondere manier van behandeling was. De ontvangst van Van Nagell's schrijven deed den ambassadeur zijn bericht dd. 16 November herhalen (b).

Inderdaad was de opening van het Parlement op den $23^{\mathrm{n}}$ November 1819 eene onverwachte en door bijzondere omstandigheden in het leven geroepen gebeurtenis. Destijds werden Londen en andere voorname plaatsen in Engeland door oproerige bewegingen van min of meer ernstigen aard verontrust, ten gevolge van gemis aan welvaart bij de lagere standen. De leiding van het verzet was in handen van de radicalen, waaronder men in dien tijd het verschrikkelijkste begreep, dat zich op het gebied der politieke partijtwisten denken liet $(c)$. Het ministerie achtte het noodig niet slechts militaire en

(a) „Lorsque le mois de Novembre fut proposé par lord Castlereagh pour l'ouverture des conférences sur les intérêts à régler entre notre Royaume et celui-ci aux Indes Orientales, ou ne prévoyait pas ici que le Parlement s'assemblerait dans le courant du même mois. J'ai pensé de suite que cette circonstance pourrait apporter quelque retard à la négociation dont il s'agit. En ayant parlé hier à lord Castlereagh ce Ministre m'a dit en effèt, qu'il craignait que les importants objets à soumettre aux délibérations du Parlement, prendraient, dans le commencement, tout son temps, comme ils demanderaient toute son attention, et qu'ainsi ce ne serait qu'après que la séance aurait duré quelques jours qu'il pouvait prononcer une opinion sur l'époque plus ou moins prochaine où nos conférences pourraient être entamées. Cela devra dépendre aussi en parti, me dit-il, de Mr. Canning qui n'est attendu que vers le 20 de ce mois, e'est-à-dire 2 ou 3 jours avant l'ouverture de la séance, et qui devra également, dans les premiers moments, se livrer exclusivement à la considération des objets sur lesquels le Parlement aura à délibérer. J'ai crû convenable d'instruire Votre Excellence de ces particularités, afin qu'Elle ne soit pas surprise si l'ouverture de ces conférences éprouvent quelque délai." (B. Z.)

(b) „J'ai été charmé d'apprendre par la dépêche de Votre Excellence du 9 N. 157 que le Roi a désigné M. le conseiller d'État Elout pour la négociation rélative aux intérêts des deux états aux Indes Orientales. Lord Castlereagh m'avait déjà dit, que lord Clancarty lui annonçait la mème nouvelle. Cette dépêche de Votre Excellence s'est croisée avec la mienne de vendredi passé No 179 par laquelle j'avais l'honneur de L'informer du délai que l'ouverture du Parlement, fixée à aujourd'hui en huit, apporterait à celle de ces conférences. Je conçois parfaitement que la présence de Mr. Elout soit assez essentielle en Hollande pour qu'il soit à désirer qu'il n'attende pas inutilement cette dernière époque à Londres. Elle devra dépendre en grande partie de la marche que les affaires prendront dans le Parlement, et dès que lord Castlereagh m'aura fait part que lui-même et Mr. Canning sont prêts, je me hâterai d'en instruire Votre Excellence, afin que Mr. Elout puisse se rendre ici." (B. Z.)

(c) "The word Radical however, conveyed a very different meaning in 1816 
politioneele macht aan te wenden, doch ook reactionnaire gelegenheidswetten in het leven te roepen. Vandaar de onverwachte bijeenroeping der volksvertegenwoordiging, die de voorstellen aannam, welke in Engelands politieke geschiedenis bekend zijn als "Lord Castlereagh's Six Acts" of "the Six Acts" (a). De wetten hadden de verwachte vitwerking; Castlereagh zag met voldoening, hoezeer de kracht der radicale partij was gebroken $(b)$. Medio Januari 1820 waren de parlementaire werkzaamheden voor den minister ten einde en besloot hij dientengevolge den $15^{\mathrm{n}}$ voor 'n veertien dagen naar Norfolk te gaan, waar zijn zwager gouverneur was, ten einde in de jacht eenige verpoozing te zoeken. Alvorens zich van zijn buitenverblijf Craifarm derwaarts te begeven, kwam hij den $12^{\mathrm{n}}$ Januari even te Londen, waarvan Fagel gebruik maakte om hem een bezoek te brengen. Onze ambassadeur deed dit wel als een beleefdheidsvorm voorkomen, doch hij hoopte tevens, dat de minister de OostIndische quaestie zou aanroeren, speciaal ook ten einde de verzekering te erlangen, dat nu stellig de onderhandelingen zouden geopend worden in de eerste week van Februari 1820, waartoe door Castlereagh zelf bij schrijven dd. 4. Januari het voorstel was gedaan $(c)$.

Fagel had het bericht hiervan den $7^{\mathrm{n}}$ Januari aan Buitenlandsche Zaken overgebracht $(d)$; doch ongelukkig veroorzaakte het zeer slechte weder, dat het schrijven eerst den $20^{\mathrm{n}}$ in Nederland kwam. Van Nagell zond het onmiddellijk aan Elout met de vraag wat deze van

to what it does now. Lord Sidmouth gravely wrote of the Radicals as the enemy. The hands of the Radicals were supposed to be against every man, and every man's hand was against them. Wherever there was a serious disturbance the rioters were usually branded as Radicals, and Radical and rioter became almost synonymous terms. Scott, when he talks of rebels in arms, always styles them Radicals. Radicals is a spirit, wrote the vicar of Harrow in 1820, of which the first elements are a rejection of Scripture, and a contempt of all the institutions of your country, and of which the results, unless averted by a merciful Providence, must be anarchy, atheism, and universal ruin." Walpole I 425-426.

(a) Zie o. a. bij Walpole I 516.

(b) "The measures of the ministry, however reprehensible they may seem in other respects, had one justification: they were successful." Walpole I 523. - Castlereagh zelf drukte er o. a. zijne voldoening over uit in een brief aan vorst Hardenberg, zie Corr. 174: $\ldots \ldots$. Radical stock is very low indeed at the present moment, and the loyal have resumed their superiority and confidence...."

(c) Zie het briefje in Bijdr. E. 64-65.

(d) Zie het briefje in Bïdr. E. 64. 
de eerste week in Februari dacht $(a)$. De oud-commissaris-generaal zou dus om zoo te zeggen op staanden voet het Kanaal moeten oversteken; dit had natuurlijk bezwaren. Eenig uitstel was daarom gewenscht, maar dan viel men weder in het parlementaire seizoen te Londen, dat altijd een hoogst ongeschikt oogenblik was om de Britsche ministers tot andere werkzaamheden te krijgen; en zoo, van uitstel op uitstel, zou de tijd niet meer ver af zijn, dat Falck zijn zetel op Koloniën kon innemen, hetgeen toch ook zeer wenschelijk bleef. Dientengevolge werd door Van Nagell, krachtens 's Konings machtiging (b), onzen ambassadeur bij schrijven dd. 21 Januari opgedragen om Castlereagh te verzoeken met de onderhandelingen eerst te beginnen tegen den aanvang van April $1820(c)$. Onze ambassadeur was hiermede nog niet bekend, toen hij, gelijk wij lazen, den $12^{\mathrm{n}}$ te voren een bezoek aan den Britschen minister bracht, om hem te vragen of de samenkomst in Februari bepaald bleef.

(a) Zie het briefje in Bijdr. E. 65 .

(b) „Bij wederzending van den bierbij gevoegden particulieren brief van den ambassadeur Fagel, heb ik de eer Uwe Excellentie te informeren, dat, uit aanmerking dat de brieven uit Engeland van den $7^{\mathrm{n}}$ dezer, eerst heden aangekomen zijn, het niet wel te verwachten kan zijn, dat aan de uitnoodiging om met den eersten Februari aanstaande de onderhandelingen nopens de wederzijdsche betrekkingen in Indië aan te vangen, voldaan worde, Zijne Majesteit zich met Uwe voordracht vereenigt om den eersten April, of zoodanig ander termijn als dan het Engelsche ministerie geraden mocht voorkomen, tot het voortzetten der bewuste onderhandelingen voor te dragen.

Uwe Excellencie's gehoorzame dienaar

's Hage, den 20 January 1820.

W. G. van de Poll." (B. Z.)

(c) „Votre lettre particulière, mon cher Monsieur, du 7 instant, ne m'est parvenu qu'hier, le 20. Le retard de 13 jours rend absolument impossible de répondre à J'invitation de Lord Castlereagh, et de vous faire assister par votre co-Commissaire pour les affaires de l'Inde: vers le commencement de Février époque si prochaine, différer de quelques jours se seroit, d'un autre côté, rencontrer le moment où les affaires parlementaires reprennent leur cours. Je vous prierais donc, mon cher Monsieur, de proposer à Lord Castlereagh de fixer l'époque des négociations à entamer aux premiers jours du mois d'Avril, ou à tel autre que son Excellence trouvera bon de déterminer.

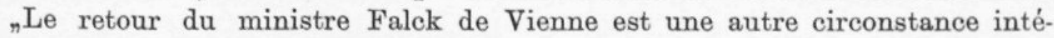
ressante pour faciliter la marche de la négociation, qui pourroit difficilement se terminer sans la participation du Ministre qui dirige les affaires des Colonies. Je me flatte que Lord Castlereagh voudra bien admettre la justesse de ces réflexions, et adopter le bref retard que les circonstances me forcent à lui demander." Deze brief in Corr. op bl. 177. Uit het in den tekst medegedeelde blijkt, dat Smulders' voorstelling op bl. 58, alsof de onderhandelingen uitgesteld werden tot April, uitsluitend wegens Falck's afwezigheid, andermaal onjuist is. 
Fagel's verwachting, dat Castlereagh wel uit zichzelf de OostIndische zaken zou aanroeren, werd vervuld, doch hij deed het op eene wijze, die diepe teleurstelling en ergernis bij onze staatslieden moest wekken. De Britsche regeering was namelijk geheel onder den indruk gekomen van de aanhoudende tot onrust opwekkende rapporten, die over het drijven der Nederlanders, uit Calcutta naar het bestuur der Compagnie te Londen werden gezonden, en juist nu, dat de onderhandelingen stonden geopend te worden, was eene nieuwe depêche dd. 17 Juli 1819 van lord Moira in Rade (Dowdeswell, Stuart en Adam) ontvangen, waarin met vernieuwden aandrang op onze grenzelooze heerschzucht gewezen, doch mede in het licht gesteld werd, dat slechts eene herziening van het tractaat van 1814, waarbij ons gezag juister moest zijn omschreven, aan het voor den Engelschen handel heilloos streven paal en perk kon stellen $(a)$. Het bestuur te Londen had dd. 25 Januari 1820 waardeerend aan de Bengaalsche regeering geantwoord, dat het zoo goed trof dien brief tijdig te hebben ontvangen, immers op het oogenblik, dat de onderhandelingen zouden aanvangen. "Your communications upon this subject", schreef toch de directie, "and particularly that which we now acknowledge, will be valuable documents in the hands of those, who treat on the part of this country" (b).

Castlereagh begon nu Fagel te verzekeren, dat hij, zoowel als Canning, oprecht eene overeenkomst wenschte, die voor beide partijen gelijkelijk billijk en voordeelig zou zijn, en dat wij er dientengevolge op rekenen konden, .... ziehier den overgang - dat men van ons niet te groote opofferingen zou eischen! Maar het door ons gekozen oogenblik tot onderhandelen, vervolgde de minister, was niet in Nederlands voordeel, het tegendeel. "Gij weet", betoogde Castlereagh nader, bestijgende het stokpaard der openbare meening in Engeland, dat steeds tegen ons als boeman dienst scheen te moeten doen, "Gij weet dat er altijd in dit land het een of ander bovendrijvend denkbeeld gedurende eenigen tijd den gang der zaken beheerscht. Tegenwoordig is het de zeer zeker overdreven meening, die de massa van het publiek is toegedaan, dat de handel in buitengewoon kwijnenden staat verkeert. Men wil daaraan volstrekt te gemoet komen, nieuwe nitwegen voor onze voortbrengselen enz. enz. zoeken, en allerlei middelen zullen daartoe in het Parlement

(a) Zie dit belangrijke stuk in bijl. 2.

(b) De Londensche depêche vindt men afgedrukt in Singapore I 501; ov. 113. 
worden voorgesteld. Men is naijverig op uwen handel in den Indischen Archipel (!!), men beschuldigt $\mathrm{u}$ van dien ten onzen koste te willen uitbreiden en wel met het doel de Engelschen uit te sluiten; en zoo zal het voor ons eene zeer zware taak worden om in het Parlement en tegen het publiek dit vooroordeel te bestrijden. Gij zult daarom van uwe zijde eenige opofferingen moeten doen en $u$ wel er van doordringen, dat het voor $u$ van wezenlijk belang is om in uwe tegenwoordige en toekomstige betrekkingen met dit land niet in volslagen strijd met de voorheerschende openbare meening te handelen, welke bijna even belangrijk voor $\mathrm{u}$ als voor ons is om te ontzien. Wees zoo goed" — besloot de minister zijne zonderlinge mededeeling - "dit baron Van Nagell te berichten en hem namens mij te verzoeken dit wel te willen overwegen." $(a)$

De lust om tot nieuwe onderhandelingen te komen, scheen alzoo van Engelands zijde er niet op toegenomen; en tegenover zoo'n taal zouden wij zeker wijzer hebben gedaan, van alle verdere pogingen af te zien, ware het niet, dat wij door Engelands wederrechtelijk bezit van Singapore wel verplicht werden, op een nader vergelijk te staan. Gelijk ik elders schreef, deze rampspoedige quaestie had het karakter van onze wenschen ter herziening van het tractaat van 1814 geheel gewijzigd (b). Onze bedaarde onthouding - naar wij uit eene vroegere verhandeling weten, tot beginsel geproclameerd $(c)$ bleek maar al te duur te staan te komen. Overigens zien wij hier hetzelfde gebeuren als in de dagen der voorbereiding tot de overeenkomst van 1814: hoe meer de tijd der onderhandelingen scheen te naderen, hoe meer de Britsche ministers onheilspellende gezichten trokken. Niet uit zichzelven, o neen! maar door die ellendige publieke opinie in het Parlement en daarbuiten $(d)$ ! Erger: hier gaat Castlereagh zich op een standpunt stellen, dat hijzelf overigens erkent niet juist te zijn, te weten het kwijnen des Britschen handels; en voor dat niet bestaand euvel behoorden wij, moesten wij, zeide

(a) Met andere woorden, maar noch brutaler hield minister Chamberlain te Glasgow dd. 5 November 1897 de volgende rede: „We believe in the greatness of the Empire. We are not afraid of its expansion. We know that for us control over the markets is an absolute necessity, and that without it we could not possibly keep in comfort all the vast population which we have in these small islands." Zie bl. 811 van het hiervoren op bl. 52 noot $d$ aangehaald artikel van Farrar.

(b) Factorijen II 444; ov. 160.

(c) Singapore I $413 \mathrm{vv}$; ov. $25 \mathrm{vv.}$

(d) Verg. Sluiting $254 \mathrm{vv}$; ov. $16 \mathrm{vv}$; het beroep op de openbare meening 265 ; ov. 27. 
de minister, ons "opofferingen" laten welgevallen.... ten einde de Engelsche bewindslieden op het kussen te houden!!

Onze ambassadeur gaf dd. 14 Januari 1820 van de zonderlinge samenkomst verslag aan Buitenlandsche Zaken (a). De lezer, die baron Van Nagell uit mijne vroegere verhandelingen eenigszins leerde kennen $(b)$, zal zich niet verwonderen, dat het op ontvangst van dit stuk in 's mans gemoed begon te koken, gelijk blijkt uit zijn antwoord van den $25^{\mathrm{n}}$ d. a. v. (c). De gebonden officieele stijl heeft hem in zijne gerechtvaardigde ergernis verlaten en is daardoor waarlijk niet slechter geworden. Zoo, luidt het in substantie, nu zullen wij "opofferingen" moeten doen, ter wille van een voorbijgaanden volkswaan in Engeland, zooals lord Castlereagh zelf als reden opgeeft! Verzoek mijnheer Castlereagh, dat hij zich eens een oogenblik in mïne plaats stelle: wat zou hij dan zeggen? Hij zou dan antwoorden: Nederland heeft reeds zoo ontzettend veel opofferingen gedaan; het is niet, dat het die terugvordert, maar wel dat het nu meester wenscht te blijven van de treurige aan het land nu eenmaal overgelaten ruïnen van een onmetelijk fortuin. Hoe! Zouden wij nu nog meer opofferingen moeten doen, en dat wijl een zijne bevoegdheid te buitengegane ondergeschikte der Engelsche OostIndische Compagnie niet opgehouden heeft ons te belasteren en den voet dwars te zetten op eene wijze, die niet anders dan de sterkste afkeuring heeft uitgelokt én van het bestuur der Maatschappij, én van de Britsche regeering! Als men toch ten slotte van dit oneerlijk drijven de vruchten wil gaan plukken, dan zullen vroeger of later waarlijk Van Nagell toonde hier een zienersblik te hebben!! — anderen dat fraaie voorbeeld ten onzen koste volgen. Heb $i k$ dan geene verantwoording, vroeg de gloeiend geworden staatsman, voor mïn parlement, voor mïn Koning? Laat lord Castlereagh zich in mijn toestand verplaatsen, herhaalde hij, en zich afvragen, of ik op rozen zit! En is dat dan eene reden om tot een ander volk te zeggen : gij zult er voor bloeden? De handel — waarvan de minister het toch al weinig moest hebben $(d)$ - nu ja, die schreeuwt altijd, niet alléén in Engeland, maar ook in Nederland; niet alleen dáá, doch over de vier windstreken der aarde. Moet men dan ten zijnen gerieve een onschuldig volk, dat slechts voor zijne rechten

(a) Zie het belangrijke stuk in bijl. 3 .

(b) Zie Sluiting en Fagel's Ontslag.

(c) Zie het merkwaardig schrijven in bijl. 4 .

(d) Zie bl. 19 hiervóór. 
opkomt, te kort doen?.... Ah, monsieur le Baron! Si lord Castlereagh se trouvait à ma place, voudrait-il, pourrait-il proposer au Roi, son maître, d'admettre en principe que nous pouvons faire un sacrifice, qui ne serait pas trop onéreux?

Niet zoo heel veel jaren later zal lord Castlereagh's hooge ambt worden uitgeoefend door lord Palmerston, wien het hinderde dat de regeering in Frankrijk tegenover hem steeds leuterde over de publieke opinie aldaar, en dan schrijft hij als minister van Buitenlandsche Zaken venijnig aan den Britschen ambassadeur te Parijs, lord Granville dd. 11 Augustus 1831: "The French Government are perpetually telling us that certain things must, or must not, be done, in order to satisfy public opinion in France; but they must remember", spatieerde de briefschrijver, "that there is a public feeling in England as well as in France; and that although that feeling is not as excitable upon small matters as the public mind in France, yet there are points (and Belgium is one) upon which it is keenly sensitive, and upon which, if once aroused, it would not easily be appeased $(a)$ ".

Onze ambassadeur moest wachten op Castlereagh's terugkomst om Van Nagell's verontwaardigd schrijven kenbaar te maken; doch het verzoek om uitstel der onderhandelingen tot April zond de ambassadeur bij brief dd. 26 Januari dadelijk naar Norfolk (b). De Britsche gezant bij ons hof, lord Clancarty, richtte ook dd. 25 Januari een schrijven aan zijn minister, waarin deze welwillend berichtte, dat het uitstel geenszins voortvloeide uit zucht om de zaken op de lange baan te schuiven, doch enkel met het oog op Falck's afwezigheid. Clancarty meende, dat bovendien dit uitstel wel aan Castlereagh zelf aangenaam zou zijn, ten einde zich aldus meer tijd voor verpoozing te knnnen schenken $(c)$.

(a) "The life of viscount Palmerston" van Bulwer. Tauchn. ed. $2^{\circ}$ deel bl. 90-91.

(b) nIt has happened rather unfortunately, owing chiefly to the late severe weather, that my letter to the Baron de Nagell, in which I informed him of your lordship's proposal of the first week in February for our Conferences on our Eastern business, only reached him on the $20^{\text {th. }}$ You will see by the enclosed (which I have this moment received) that they are not quite prepared, on the other side of the water, for so early a beginning of these deliberations, M. Falck's absence is certainly very inconvenient. I have a letter from M. Elout to the same effect. They would wish the Conferences to be put off till the first week in April. I shall be anxious to communicate your answer on this subject as soon as possible to Baron Nagell. May I request you to return me the enclosed?" Corr. bl. 176.

(c) "You will see they are desirous here of postponing your Eastern negociation till April. I believe the real reason of this to proceed from no 
Voor Fagel daarentegen was de ontvangst der depêche eene teleurstelling, wijl de aanstaande parlementaire werkzaamheden nog verder verschuiving van de onderhandelingen zouden ten gevolge hebben; hij hoopte echter, schreef hij dd. 28 Januari aan Buitenlandsche Zaken, dat de aldus beschikbaar komende tijd aan eene grondige studie der zaken ten goede kon komen $(a)$.

Eene onverwachte gebeurtenis was oorzaak, dat er wellicht toch uitstel zou ontstaan zijn, ook al had men er onzerzijds niet om verzocht.

Den $29^{\mathrm{n}}$ Januari overleed koning George III op 82-jarigen leeftijd. De vorst, wiens benepen opvatting omtrent de regeeringstaak, in enorm veel opzichten doet denken aan onzen Willem I (b), was de laatste 10 jaren zijner langdurige regeering, slechts nominaal het hoofd van den Staat geweest, daar wegens zielsziekte zijn zoon, de kroonprins, als regent het rijk bestuurde; deze aanvaardde nu als koning de regeering onder den naam van George IV, doch werd in dezelfde week zóó ernstig ongesteld, dat voor het behoud van zijn leven gevreesd werd.

Natuurlijk dat Castlereagh zich haastte naar Londen terug te

diminuation of their desire to come as soon as may be to a final arrangement upon this matter, but that they feel somewhat the want of Falck, now absent at Vienna, and would, upon the whole, rather that he was present than absent, during the negociation. I do not believe you will be inclined to thwart them in this view, conceiving rather that some little relaxation will be of use to you; but, if you should wish otherwise, the mere expression of your wish will send M. Elout over to you directly." Corr. 176.

(a) „Lord Castlereagh étant toujours en Norfolk je me suis hâté, mon cher Monsieur, de lui faire part par écrit du contenu de votre lettre particulière du 21 dans laquelle vous proposez de remettre leś conférences sur nos affaires aux Indes Orientales jusqu'au commencement d'Avril. Dès que j'aurai reçu sa reponse je vous la communiquerai. En mon particulier je regrette ce délai, surtout parce qu'il nous jette dans cette espèce de carnaval, dont Londres est le théâtre dans les mois d'Avril, de Mai et de Juin, et qui est ici de toute l'année le temps le moins propre aux affaires: mais je me flatte que, comme on aura eu des deux côtés celui de se bien préparer, la matière en pourra ètre d'autant plus promptement approfondie et terminée.

„Recevez, je vous en prie, les assurances les plus cordiales de mon entier et invariable dévouement.

\section{H. FAGEL." (B. Z.)}

(b) Over George III b. v. Walpole I 242 vv.: „Qualities, which are rightly accounted as virtues in other men, are occasionally dangerous when they are found in princes." Beide vorsten, hoe achtenswaardig ook in menig opzicht, bemoeiden zich te zeer met bijzonderheden, waren even stijfhoofdig en verloren door gemis aan inzicht, de eene Noord-Amerika, de andere België. 
keeren, doch om Fagel even in te lichten, naar aanleiding van het verzoek tot uitstel van 26 Januari, scheen de tijd te ontbreken. Gevoeligheid hierover hadden wij echter niet. "Seedert", schreef namelijk Fagel dd. 4 Februari aan Elout $(a)$, "hebben zich de dood van den overleden Koning, de komst van den teegenwoordigen tot den Throon en de ziekte Zijner thans regeerende Majesteit zoo spoedig agter elkander gevolgd, dat het mij niet verwondert nog zonder antwoord van Zijne Lordschap te zijn; dog ik heb alle reede te vermoeden, dat deeze omstandigheeden, die een groote drukte veroorzaaken, hier ook zullen pleiten voor het renvoi der onderhandelingen tot een laater tijd, waarvan de bepaaling grootendeels zal afhangen van de dissolutie van het teegenwoordige en van de bijeenkomst van het nieuwe Parlement."

Eindelijk gelukte het onzen ambassadeur den $7^{\mathrm{n}}$ Februari toegang tot den machtigen bewindsman te krijgen; Fagel zou daar het antwoord gaan halen en tevens de verontwaardigde boodschap van Van Nagell overbrengen. Een pijnlijke gang, denk ik. De beide mannen, die elkander waardeerden, hoogachtten, bevriend waren, moesten nu tot een standpunt komen, waaronder de verhoudingen niet anders dan konden lijden; en wat er ten slotte voorviel scheen dit nog ernstiger te zullen maken.

Het spreekt wel vanzelf, dat de minister tegen het verzochte uitstel volstrekt geen bezwaar bleek te hebben; doch toen het gesprek over het tweede punt kwam, verklaarde opeens lord Castlereagh, tot niet geringe verbazing van zijn bezoeker, dat het woord opofferingen volstrekt niet gebruikt was, dat Engeland ook geen recht had ze te vorderen en ook niet voornemens was dat te doen. Hij had er alleen tegen willen waarschuwen, verzekerde de minister, dat 's Lands wet hem tot groote voorzichtigheid noopte, en dat, zoo Nederland niet tot eenige redelijke schikking te vinden zou zijn, er niets anders kon overblijven, dan de zaken te laten, zooals ze waren, hetgeen aan beide partijen zeker min wenschelijk moest schijnen.

's Lands wet! Kostelijke illustratie van Montesquieu's gedachte: "L'Angleterre, souverainement jalouse du commerce qu'on fait chez elle, se lie peu par des traités et ne dépend que de ses lois." (b)

Fagel's antwoord aan Castlereagh op deze pertinente ontkenning van hetgeen indertijd volgens den gezant gezegd zou zijn, was

(a) B̈̈jr. E. 66.

(b) Rochussen 1. 
diplomatisch genoeg. Over de gebruikte woorden, luidde het, meende hij niet te mogen twisten. Het kon wel zijn, dat het woord "opoffering" niet in den bedoelden zin was gebezigd; hij koesterde echter de overtuiging, voegde Fagel tevens Castlereagh toe, dat deze hem in zoover recht wilde doen wedervaren, dat door hem steeds met de grootste zorg de gesprekken werden wedergegeven en dat over het algemeen en voor zoover menschelijke dwaling toeliet, zijne rapporten zoo getrouw waren als zijne bedoeling steeds was geweest ze te stellen.

Maar in zijn rapport dd. 8 Februari, waarin hij tevens Buitenlandsche Zaken omtrent de goedkeuring van het uitstel inlichtte, deelde de ambassadeur duidelijk genoeg mede, dat de Britsche bewindsman zich in zijne ontkenning vergiste. Er viel toch alleen van te zeggen, meldde Fagel, dat indien rapporteur nogmaals den indruk van het gehouden gesprek over de "opofferingen" moest wedergeven, hij er geen woord in zou veranderen. $(a)$

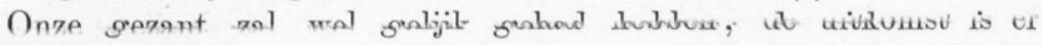
althans mede in overeenstemming gekomen, daar wij ten slotte wèl met een sacrifice trop onéreux genoegen moesten nemen. Poeloe Pinang, eertijds door onze staatslieden als op den koop toe voor ingeruild gedacht $(b)$, kwam in het geheel niet meer als eene verkrijging ter sprake. De geldelijke balans door Commissarissen-Generaal zoo netjes ten onzen voordeele in elkander gezet, sloeg om in eene schuld ten onzen laste van f 1.200.000! De illusie om het Engelsche deel van Sumatra's $W$ estkust te verkrijgen, enkel in ruil voor onze bezittingen in Vór r-Indië, verdween in rook. Singapore moesten wij met opoffering der belangen van onzen bestolen vazal prijsgeven. Malakka, weleer door Elout nog zoo krachtig als een noodzakelijk Nederlandsch bezit op den voorgrond gesteld $(c)$ en dat ons in den lateren Atjeh-oorlog en over het algemeen in onze betrekkingen tot de landschappen van Sumatra's Oostkust van zooveel dienst had kunnen zijn, ging mede aan Engeland over; en aan het uitgangspunt onzerzijds van de onderhandelingen: onverdeeld bezit op Sumatra werd ten slotte zóó weinig de hand gehouden, dat wij ons uitdrukkelijke, zoowel als stilzwijgende, beperkingen lieten welgevallen, die nog tot velerlei hindernis zouden

(a) Zie het rapport in bijl. 5 .

(b) Zie Factorïen II 424, 434, 435, 437; ov. 140, 150, 151, 153.

(c) Malacca moeten wij nooit afstaan: Factorijen $\amalg$ 424; ov. 140. Het jamais van Rouher: 
aanleiding geven $(a)$. Voor dit alles kregen wij, behalve het in zekeren zin aan Engeland slechts uitgaven veroorzakende Benkoelen, verdragmatige erkenning van rechten, die, bij eene onbevangen opvatting van het tractaat van 1814, voldoende gewaarborgd mochten heeten; zoomede toezeggingen van Engelands zijde, als weerslag op de onze, die echter feitelijk tegen Nederland waren gericht en waaromtrent alleen de wederkeerigheid werd in acht genomen, niet omdat wij ons met de zaak zelve gediend achtten, doch omdat men, althans voor het uiterlijke, die gelijkheid wist in acht te nemen, zonder welke de zwakkere contractant in de oogen van derden werd verlaagd, waartegen wij vroeger weleens geen bezwaar hadden gehad, doch in een tijdperk van vernedering dat we voor gesloten moesten wanen $(b)$.

Overigens weet nu de lezer met het openbaar maken van Van Nagell's en Fagel's brieven, wat onze minister van Buitenlandsche Zaken met de zonderlinge correspondentie eigenlijk bedoelde, toen hij dd. 11 Februari 1820 het volgend briefje in de Nederlandsche taal aan Elout zond, hetwelk men in diens Bijdragen zonder nadere aanduiding afgedrukt vindt $(c)$ :

Met de Engelsche Post van heeden heb ik, mijn hooggeachtsten Vriend! tijding bekoomen, dat Lord Castlereagh genoegen nam in het uitstellen der bewuste onderhandelingen over de belangens in Oost-Indië, tot het begin van April. - Wanneer UHEGestr. eens eenige oogenblikken te spaaren heeft, zal ik haar eene zonderlinge correspondentie kunnen mededeelen.

's Hage, I I Februarij I820. A. W. C. VAN NAGell.

VI.

\section{Falck's verblijf te Weenen en het proces tegen de Koningin van Engeland: 1819_-1820.}

Van Weenen uit zag Falck de toekomst onzer onderhandelingen donker in, speciaal, gelijk hij dd. 13 December 1819 aan Elout schreef, wijl Raffles maar altijd, in weerwil van de officieele afkeuringen, niet slechts gehandhaafd bleef, doch zelfs eene soort

(a) Verg. Atjeh 200; ov. 42.

(b) Verg. bl. 358-359 dl. I van Dr. H. T. Colenbrander's „Patriottentijd" (1897).

(c) Bïdr. E. 66. - Verg. hiervóór bl. 9 onder 18. $7^{\circ}$ Volg. II. 
van machtiging scheen te hebben ontvangen, ingevolge waarvan Singapore was verrezen $(a)$. Zijne hoop bleef echter gevestigd op de grootere eerlijkheid van het Londensch opperbestuur. "De valschheid van vele allegatiën", oordeelde hij over de beweerde Engelsche rechten op Singapore, "springt nu reeds tegen het voorhoofd; maar zal nog veel duidelijker betoogd en de Engelsche Ministers zelve aan het verstand gebragt kunnen worden.... Engelsche ministers, zeide ik zoo even, omdat ik niet deelen kan in v. d. Capellen's hoop, dat de kwestie in Bengalen ten onzen voordeele zoude beslist worden (b). De omstandigheid, dat het Supreme Gov ${ }^{\mathrm{t}}$. Raffles, na hem in andere opzigten gelaakt en gedesavoueerd te hebben, met eenige volmagt naar de Straat van Malakka heeft gezonden (en hieraan, dunkt mij, valt niet te twijfelen), beschouw ik bij voortduring als een ongunstig teeken" $(c)$. - Op het bericht van het uitstel der onderhandelingen tot April, schreef hij nader, zoowel aan Elout als aan Van Lennep, dat hij naar Holland ten zeerste terug verlangde, ook omdat hij er de noodzakelijkheid voor den dienst aan het departement van Koloniën inzag. Hij hoopte tegen het einde van Maart in Nederland te zijn, maar voegde hij er profetisch aan toe: "Bij den dood van George III, en de schikkingen, zoo parlementaire als andere, die daarvan het gevolg moeten zijn, staat het te bezien of de Engelschen April zelfs niet te vroeg zullen vinden voor den aanvang der onderhandelingen" $(d)$.

Oorspronkelijk scheen evenwel de maand geschikt te blijven. Immers, toen Castlereagh in den aanvang van Maart zich gereed makte voor zijne verkiezing naar Ierland te gaan en onze ambassadeur hem daarom nog vòòr zijn vertrek bezocht om te weten of nu op April gerekend kon worden, had Fagel de verzekering ontvangen, dat geene bezwaren er tegen bestonden. Met deze verwachting werd de maand Maart ingegaan, toen Elout, wegens Falck's blijvende afwezigheid, bij schrijven dd. 10 dier maand, Fagel polste, in overeenstemming met Buitenlandsche Zaken, over een

(a) Zie de ware toedracht in Singapore I 398, 406, 419, 421; ov. 10, 18, 31, 33.

(b) Toen Falck dit schreef, had ook Van der Capellen alle hoop op eene rechtvaardige beslissing te Calcutta verloren en verwachtte hij evenzeer slechts heil van Londen. Zie zijne brieven dd. 9 November en 16 December 1819 in Singapore I sub 60 en 61 .

(c) Het schrijven zoowel in Bïdr. E. 62-63, als in Falck's Brieven 244-246.

(d) Zie zijn brief aan Elout dd. 14 Februari 1820 in Bijdr. E. 66-67 en aan D. J. van Lennep dd. 29 Januari 1820 in Falck's Brieven 247-250. 
nieuw nitstel $(a)$. De ambassadeur antwoordde den $14^{\mathrm{n}}$ Maart (b). Hij zou er bij Castlereagh's terugkomst over spreken; hij erkende de wenschelijkheid van Falck's terugkomst, doch vond het vernieuwd uitstel niettemin jammer, te meer, wijl van Engelsche zijde geene bezwaren meer waren gemaakt en juist de tijd tusschen aanvang April en den $21^{\mathrm{n}}$ d. a. v. als wanneer het Parlement weder bijeen kwam, nuttig kon worden gebruikt. "Ik weet bij ondervinding", lichtte hij nader toe, "dat wanneer het Parlement bijeen is, vooral in het voorjaar, de drukte zoo groot is, dat de Ministers bijna niet te genaken zijn. Ik zoude Uw HEdGestr. dus durven aanraden zich in gereedheid te houden om de reize te kunnen aanvaarden, zoodra men hier gereed zal zijn." Maar ook nu weder maakte de Britsche minister zelf dat nakomen van den afgesproken datum onmogelijk, daar Castlereagh zóó lang wegbleef, dat Fagel eerst den $13^{\mathrm{n}}$ April gelegenheid vond, om hem te spreken! En toen, nog vóór de ambassadeur wenschen tot uitstel had uit te brengen, verzocht de minister uit zichzelf, den aanvang der samenkomsten te verschuiven tot einde Juni, bezwaard als hij was door parlementairen arbeid, gelijk Fagel denzelfden dag aan Buitenlandsche Zaken berichtte $(c)$. Elout, die hiervan bij een briefje van Van Nagell dd. 17 April kennis kreeg $(d)$, uitte er zijne voldoening aan Falck te Weenen over, "want waarlijk", schreef hij hem dd. 3 Mei (e), "vóór mijn vertrek moet ik met u spreken, gedurende mijn verblijf in Engeland met u corresponderen." Den $17^{\mathrm{n}}$ Mei herinnerde Van Nagell alsnog aan Elout, dat volgens bericht van onzen ambassadeur, de Britsche gevolmachtigden nu rekenden op het einde van Juni $\left(f^{\prime}\right)$.

De terugkomst alsdan van Falck was nog onzeker. Elout correspondeerde er met Fagel over; beiden waren nu niettemin van oordeel, dat het gewicht der zaak geen langer uitstel gedoogde. "'s Konings krooning", schreef de gezant dd. 20 Mei $(g)$, "op den

(a) De brief werd door Van Nagell's tusschenkomst opgezonden; zie Bïjdr. E. 68.

(b) Zie den brief aan Elout in $B \ddot{j} d r$. E. 67-68.

(c) Zie het rapport in bijl. 6. - Hieruit en ook uit hetgeen volgt, blijkt dat Smulders' voorstelling op bl. 38 , alsof Falck's voortdurende afwezigheid uitsluitend oorzaak was van de vertraging: „zoodat eerst in Julij van hetzelfde jaar de beraamde onderhandelingen te Londen konden plaats hebben", niet geheel juist is.

(d) Bïjdr. E. 68.

(e) In Bijdr. E. 69-71.

(f) $B \ddot{j} d r . E .71$.

(g) De brief in Bïdr. E. 71-72. 
$1^{\mathrm{n}}$ Augustus vastgesteld (naa dewelke noch ministers, noch Leden van het Parlement geen duur meer zullen hebben in de stad en alles zich naar buiten zal spoeden), beperkt reeds meer dan te veel den tijd, die ons nog zal verblijven." Het bezwaar omtrent het afwezen van onzen minister van Koloniën verviel bovendien door zijne terugkomst in Juni (a). Vandaar het Koninklijk besluit dd. 22 Juni $1820 \mathrm{~N}^{0} 35$, houdende de benoeming van Fagel en Elout tot gevolmachtigden (b). Op de vaststelling der instructie na, was Elout nu gereed om te vertrekken, toen eene nieuwe onverwachte gebeurtenis in Engeland andermaal de zaak deed verschuiven.

De pas opgetreden koning van Engeland had als prins van Wales een weinig gelukkig verleden achter zich. "He was" — en met deze schets van Walpole kan men volstaan $(c)$ — " a bad son, a bad husband, a bad father, a bad subject, a bad monarch, and a bad friend." Ongehuwd, leidde hij een losbandig leven, in het bijzonder met zekere Fitzherbert. Eindelijk zat hij zóó diep in schulden, dat het Parlement moest te hulp komen. De discussiën, die uit zijne minnarijen waren voortgevloeid, prikkelden hem ten slotte om te huwen met de keuze zijns vaders, prinses Caroline van Brunswijk, de tweede dochter van 's Konings zuster; hierin lag het eenige middel om uit zijne schulden te geraken. Het huwelijk werd in 1795 gesloten; maar de Kroonprins zette zijn losbandig leven voort, en om de schandalen te vermeerderen, begon weldra zijne gemalin tevens aanstoot te geven. Na slechts weinige maanden te zijn gehuwd, verhuisde zij naar Blackheath, waar al hare gedragingen, op last van den Prins, werden bespied. Eindelijk riep men hare eigen bedienden op, om in het huis der Lords tegen haar te getuigen; onschuldig verklaard, toog zij in 1814 naar Italië, ten einde zich vrijer te kunnen bewegen. Met goedkeuring van het ministerie, speciaal van de ministers Liverpool en Eldon, zond de Prins, destijds regent, in 1818 naar Italië eene commissie, om

(a) Ten gevolge van de Weener slotacte dd. 15 Mei 1820.

(b) Afgedrukt in $B i j d r$. E. 73-74, met de verkeerde jaartallen 1829 op de eene bladzijde en 1823 op de andere! - Smulders schrijft op bl. 38, dat gevolmachtigden werden Fagel en Falck, wellicht omdat de schrijver te zeer verband zocht tusschen het tijdstip der onderhandelingen en Falck's verblijf te Weenen. - In De Sturler's proefschrift, bl. 206 noot 2, werd bereids hierop de aandacht gevestigd; maar de fout is overgenomen op bl. 175 dl. II (1873) van J. J. Meinsma's Geschiedenis van de Nederlandsche OostIndische besittingen, en nog eens op bl. 177 herhaald, dat „Falck in 1820 gevolmachtigde was geweest".

(c) Di. I 246. 
nieuwe aanklachten tegen haar te verzamelen, ten einde zich te kunnen doen scheiden. Zoo stonden de zaken, toen de vorst in Januari 1820 koning werd. Zonder kinderen — de eenige dochter was in 1817 overleden - haakte de onwaardige vorst naar de scheiding, waartoe, zijns inziens, de Italiaansche commissie genoegzaam gegevens had bijeengebracht. Het ministerie deinsde echter voor het schandaal terug en wilde de Koningin enkel doen besluiten, nooit meer naar Engeland terug te keeren; de Koning werd verplicht hiermede genoegen te nemen. Misschien zou men daartoe ook wel de vorstin hebben overgehaald, mits men slechts hare koninklijke waardigheid had blijven erkennen. Dat de Engelsche vertegenwoordigers in den vreemde de opdracht kregen aan de hoven te verzoeken, de Koningin niet te ontvangen, was reeds erg; wat haar echter tot persoonlijk optreden aanzette was .... eene heiliging ! In de geschiedenis der volken speelt de voorbidding soms eene gewichtige rol. Zulke ellendelingen kunnen de vorstelijke personages niet zijn, of ze blijken toch bijzonder gesteld op deze wekelijksche openbare huldiging in Gods bedehuizen. In onze eigen vaderlandsche geschiedenis, in den stadhouderloozen tijd van Johan de Witt namelijk, kreeg die formulierquaestie een belang, groot genoeg om later een bekwaam essayist over hare geschiedenis eene gansche verhandeling te doen schrijven $(a)$; in ons Indië zouden eerlang twee vorstelijke broeders er elkander over te lijf willen gaan (b); en zoo kwam ook nu gansch stichtelijk Engeland in beweging door den wensch des Konings, dat zijne gade niet in het gebed bij de openbare godsdienstoefeningen mocht genoemd worden $(c)$. Terecht begrepen de gegeloovigen, dat dit niet aanging; als men waarde hechtte aan zulk een formalisme, dan diende juist voor eene afgedwaalde Gods goedertierenheid te worden ingeroepen $(d)$.

Toen de Koningin door lord Brougham op de hoogte was gebracht, wendde zij zich uit Rome onmiddellijk tot lord Liverpool, tevens mededeelende, dat zij naar Engeland terugkwam (e). 'Maar het ministerie achtte zich sterk met de bewijzen van hare schuld, dank

(a) "Het publiek gebed"; dl. II 68-94 der Historische Schetsen van Mr. D. Veegens (1885).

(b) Palembang 381-382; ov. 51-52.

(c) In het ontworpen formulier kwam namelijk voor: "That it may please Thee to bless and preserve our gracious Queen, Caroline, their Royal Highnesses the Duke and Duchess of York, and all the Royal Family."

(d) Zie o. a. de bijzonderheden bij Martineau 326 vv. en Walpole I 526 vv.

(e) Men leze haar origineelen brief dd. 16 Maart 1820 bij Walpole I 566. 
ook de goede diensten door Oostenrijk bewezen (a). Te Calais aangekomen, zou zij zich nog weleens bedenken, hoopte men, want de Regeering beloofde haar geld, en anders.... vervolging wegens overspel (b).

De beschuldigde liet zich echter evenmin door bedreigingen als door gouden bruggen weerhouden; onder het gejuich des volks deed zij den $6^{\text {n }}$ Juni 1820 hare intrede binnen Londen. Wat ook hare schuld mocht zijn, men verachtte den vorst, die niet minder in bandeloosheid leefde en onwaardig zijne gade aan den openbaren smaad trachtte prijs te geven; ook de hulpelooze, door de machthebbenden vervolgde vrouw, die nochtans hare rechten durfde handhaven, werkte op de verbeelding. Hare reis naar de hoofdstad was slechts één zegetocht $(c)$. De paarden werden van het rijtuig gespannen, in weerwil van de pogingen der omgeving om dit te beletten. Vele huizen ontstaken aan den avond harer komst te Londen verlichting; $\mathrm{n}$ enkele aanzienlijke woningen, waar dit werd nagelaten, wierp het volk de ruiten in; ook Castlereagh's hotel moest het ontgelden $(d)$. Als in deze dagen hij en minister Sidmouth arm in arm de Parlementstraat afliepen, onder het geloei van het hen omringend gepeupel, kon Sidmouth niet nalaten op te merken: "Hier gaan we, de twee meest populaire mannen in Engeland." — "Ja, door eene dankbare en bewonderende menigte", was Castlereagh's onverstoord antwoord.

Aldus kwam het tot de vervolging. In twee groen verzegelde bundẻls werden de stukken dd. 6 Juni 1820 het Parlement aan-

(a) "The Emperor of Austria was the first person who informed the King of the Queen's conduct in Italy". Greville 57.

(b) Nog den $6^{\text {n }}$ Mei 1820 schreef Castlereagh aan Metternich, Corr. 259: "Our session is likely to be a troublesome one, and to me it begins inauspiciously, having been seized by the gout two days before the battle was to commence. I am, however, getting better, and expect to be in my place in the course of next week. Much will depend on the course her Majesty shall think flt to pursue. If she is wise enough to accept the pont d'or which we have tendered her, the calamities and scandal of a public investigation will be avoided. If she is mad enough or so ill-advised as to put her foot upon English ground, I shall, from that moment, regard Pandora's box as opened. I cannot sufficiently express how much I feel your Highness's conduct upon this question. You have given us in the most handsome and honourable manner the full weight of your authority; and I have no doubt your individual opinion has had its due weight in reconciling our royal master to the advice which his Ministers felt it their bounden duty to give to his Majesty."

(c) Zie b. v. ook de Haarlemsche Courant van 13 Juni 1820.

(d) Men zie o. a. Greville 28 vv. 
geboden, door lord Liverpool in het Hooger-, door lord Castlereagh in het Lagerhuis $(a)$. Den Zondag daarop koos een geestelijke tot tekst voor hetgeen hij zou zeggen Job XIV vers 17: "Mijne overtreding is in een bundelken verzegeld, en gij pakt mijne ongerechtigheden op een"!! (b)

Te midden nu van dezen bewegingsvollen tijd, waarvan ook ambassadeur Fagel ons ministerie op de hoogte hield (c), lag het voor de hand, dat aan het openen van onze onderhandelingen niet te denken viel. Denzelfden $6^{\mathrm{n}}$ Juni voorspelde dan ook ambassadeur Fagel aan Buitenlandsche Zaken, dat de Britsche gevolmachtigden noch gelegenheid, noch lust zouden hebben om zich rustig tot het werk neder te zetten en alsnu uitstel inévitable zou blijken. Niettemin deed Castlereagh weder niets van zich hooren, zoodat Fagel het andermaal oirbaar achtte den $11^{\mathrm{n}}$ Juni naar den minister te gaan. Ternauwernood had de gezant het onderwerp aangeroerd, of Castlereagh verzocht hem onzen Koning door Van Nagell in overweging te doen geven, de werkzaamheden te verschuiven tot men de handen wat meer vrij had. De drukte, waaronder het ministerie gebukt ging, gelijk hij, Fagel, zelf kon weten, merkte Castlereagh op, maakte dit noodzakelijk. Zoo ging onze gezant naar huis voor de opstelling van een rapport dd. 13 Juni, warin hij over de gebeurtenissen van den dag uitweidde en in verband daarmede berichtte, dat de onderhandelingen onbepaald waren uitgesteld $(d)$ ! Doch twee dagen later liet het zich voorzien, dat het uitstel zoo lang niet meer zou duren, omdat opnieuw onderhandelingen met de Koningin waren aangeknoopt, die, zoo ze slaagden, aan het proces een einde moesten maken. "Ik vlei mij echter", schreef uit dien hoofde de ambassadeur aan Elout den $15^{\mathrm{n}}(e)$ : "dat

(a) Zie 's Konings brief en de aanbieding door Castlereagh in SpeechesCanning IV 228-229.

(b) Het is Job's klacht tegen Gods onrechtvaardige gestrengheid. Ware het anders, luidt het eigenlijk in de fraaie nieuwe overzetting van het Oude Testament:

16 dan zoudt gij mijne schreden tellen, maar niet loeren op mijne zonden;

17 veeleer in een buidel mijne misdrijven verzegelen, mijne schuld overpleisteren.

Een groot verschil dus, en minder pakkend.

(c) Zie o. a. zijn rapport van 13 Juni 1820 in bijl. 7 .

(d) Zie het extract van den brief in $B \ddot{j} d r$. $E$. 75 .

(e) Zie Bïjr. E. 76 . 
dit uitstel van geen langen duur zal zijn, en dat, wanneer deze zaak vereffend is (waarmede men zich vleit) U Hoog Ed. Gestr. zal uitgenoodigd worden om zich tegen het begin van Julij herwaarts te begeeven. Ik wensche zulks te meer, daar de Heer Canning mij gisteren aan 't Hof, naar den tijd van Uwe aankomst vraagende, te kennen gaf, dat hij zeer verlangde, terstond naa de Krooning, de Reize naar Italien te aanvaarden, alwaar Zijne Gemalinne en Kinderen zich seedert eenige maanden bevinden. U Hoog Ed. Gestr. ziet hoezeer dit strookt met hetgeen ik de eer had $\mathrm{U}$ in mijne laatste te melden van de waarschijnlijkheid, dat na de Krooning alles, oud en jong, groot en klein, Ministers en Leden van 't Parlement uit de stad naar buiten zouden snellen."

Weliswaar moest de Regeering den $19^{\mathrm{n}}$ Juni aan het Parlement berichten, dat partijen het ook nu niet eens hadden kunnen worden, zoodat in den anvang van Juli een wetsontwerp werd overgelegd, geheeten: "An act to deprive Her Majesty, Queen Caroline Amelia Elisabeth, of the title, prerogatives, rights, privileges, and exemptions of Queen-consort of this realm, and to dissolve the mariage between His Majesty and the said Caroline Amelia Elisabeth"; maar de Koningin kreeg nu vier maanden tijd voor hare verdediging, zoodat het Parlement werd gesloten en eerst in November 1820 weder bijeengeroepen zou worden, schreef Fagel dd. 30 Juni aan Buitenlandsche Zaken (a).

Er was alzoo voorloopig rust genoeg in den lande, om de Britsche gevolmachtigden tot onderhandeling gelegenheid te geven. Wel zonden zij hiervan alweder geen vormelijk bericht, maar hunne bereidverklaring vernam onze ambassadeur den $28^{\mathrm{n}}$ Juni op eene receptie ten hove, waar hij Castlereagh en Canning ontmoette; ze verzochten hem daar, Elout onmiddellijk te laten overkomen, ten einde de werkzaamheden te beginnen. Falck bracht deze belangrijke tijding bij brief van den $30^{\mathrm{n}}$ naar 's-Gravenhage over $(b)$. Zoo zouden nu

(a) "L'on croit à présent qu'à la suite du rapport du Comité Secrêt, annoncé pour lundi prochain, un bill penal (bill of pains and penalties) ayant la Reine pour objet, sera présenté à la Chambre Haute. Il faudra alors donner à Sa Majesté le temps de se défendre et à cet effèt le Parlement sera ajourné pour 3 ou 4 mois, de manière à s'assembler de nouveau pour la poursuite de l'affaire en Novembre. D'après cela on commence à parler d'un prochain ajournement qui pourra terminer la présente session dans une quinzaine de jours." (B. Z.)

(b) Zie het bericht in de daarmede gepaard gaande correspondentie tusschen Van Nagell en Elout in Bïdr. E. 77-78. 
werkelijk de onderhandelingen aanvangen, na viermaal te zijn verschoven, immers van November 1819 op Februari 1820; toen op April; daarna in Juni; eindelijk voor onbepaalden tijd.

VII.

\section{De onderhandelingen van Juli-Augustus 1820 .}

Veel tijd tot voorbereiding had men in Nederland niet meer noodig. Reeds in November 1819 was door Fagel aan Elout, op diens verzoek, inlichting verstrekt over den te voeren staat en rang. Eene deftige kamer en eene goede equipage werden o. a. als hoofdvereischten genoemd. Diners of dejeuners zou niemand van hem verwachten; een kamerdienaar, een liverei-knecht om achter de koets te staan en een huurlakei zouden den staat "alleszins gepast en volledig maken". Een secretaris, amanuensis, behoorde medegebracht te worden en Elout's titel moest zijn die van plenipotentiaris, "zijnde deeze Titel bij diergelijke geleegenheden gebruikelijk en sluitende die in alle diplomatieke onderscheidingen van Rang, van den hoogsten tot den laagsten" $(a)$. — Overeenkomstig deze aanwijzingen had de benoeming als plenipotentiaris reeds plaatsgevonden in Juni (b); de commies van staat, $C$. T. Serruys werd als amanúensis toegevoegd $(c)$. Elout ontving voor de reis heen en terug ineens $\mathrm{f} 2000$ en een daggeld van f 80 : "allezins toereikende en betamelijk", had Fagel gevonden. Den $8^{\mathrm{n}}$ Juli geschiedde de vaststelling door den Koning van de volmacht: "Promettant d'accomplir et exécuter ponctuellement, tout ce que nos dits Plénipotentiaires, ou même, l'un des deux, en cas de maladie, d'absence ou d'autre empêchement de l'autre, auront promis et signé en Notre nom, comme aussi d'en faire expédier Nos lettres de ratification en bonne forme et de les faire délivrer pour être échangées dans le tems dont il sera convenu" $(d)$. - Den $10^{\mathrm{n}}$ eindelijk had de vaststelling der instructie plaats; dit belangrijke stuk, mede in Elout's Bijdragen opgenomen $(e)$, en, naar wij weten, uit diens Consideratiën van Novenber 1819 voortgevloeid, verdient eenige nadere beschouwing.

De 16 artikelen werden voorafgegaan door eene breede inleiding.

(a) In den brief van 15 November 1819 in $B \ddot{j} d r . E .60$.

(b) Zie bl. 68 .

(c) Zie het nader besluit dd. 15 Juli 1820 in $B \ddot{z j d r . ~ E . ~} 92$.

(d) Zie de volmacht in Bïdr. E. 79.

(e) Op bl. $81 \mathrm{vv}$. 
Zij bracht in herinnering de oorzaak der onvolledigheid van de in 1814 gesloten conventie $(a)$; het gemis aan goede trouw bij de Britsch-Indische ambtenaren; het onbetamelijk optreden van Raffles en den steun, dien hij, in weerwil van alle afkeuring door de Engelsch regeering, van haar had ondervonden. De inleiding zet verder zeer logisch uiteen de redenen, dat niet kon getreden worden in den door Clancarty gedanen eisch om onze rechten enz. in den Archipel te omschrijven en te bewijzen; eindelijk werd "het natuurlijk, zoowel als verkieslijk voor ons" vermeend, dat eerst van de Engelsche regeering voorstellen werden ingewacht, daar, leest men ter motiveering van deze achterhoudendheid, "de Engelsche regering nog sterker dan van Onze zijde gedaan is, op het houden van conferentiën tot het regelen der wederzijdsche belangen in Azië, heeft aangedrongen". Ik heb dien indruk bij de lezing der stukken niet gekregen.

Wat de artikelen betrof, gevolmachtigden moesten streven onze geldelijke vorderingen "op de voordeeligste wijze te doen beschouwen en regelen" (art. 1); het status ante bellum behoorden zij indachtig te zijn (artt. 2 en 12). Met dat al behoefden zij zich niet strikt aan de voormalige motieven van Commissarissen-Generaal te houden, daar "die argumenten gegrond waren op begrippen van strikt regt, van welke Commissarissen-Generaal zich niet bevoegd rekenden om te glisseren". Hoe men Elout weder geheel als lawyer in deze instructie terugvindt; alsof de toenmalige Indische regeering niet volkomen bevoegd geweest ware, overeenkomstig 's lands belang te handelen! $\mathrm{Nu}$ eerst echter, luidde het verder, kwam het aan "op eene schikking in der minne, waarbij de billijkheid en de omstandigheden, die de tijdelijke administratie moeijelijk hebben gemaakt, alleszins in aanmerking verdienen te komen"; het werd alzoo aan de "prudentie" der gevolmachtigden overgelaten om tot een vergelijk op geldelijk gebied te geraken (art. 3). Geen eisch tot waarborging der contracten, onder het Engelsch bestuur met Palembang gesloten, mocht ingewilligd, evenmin ons bezitrecht op Banka een onderwerp van bespreking worden (b) (art. 3); daarentegen moesten onze gevolmachtigden de erkenning van ons recht op Billiton uitlokken $(c)$ (art. 4). De artt. 5, 6 en 7 handelden breedvoerig over de ruiling van onze factorijen in Vóór-Indië tegen Benkoelen $(d)$;

(a) Verg. Sluiting 243-244; ov. 5-6.

(b) Zie Palembang 369-372; ov. 29-31.

(c) Zie Palembang 386-388; ov. 46-48; Singapore II 340; ov. 28.

(d) Zie die artikelen in Factorïen II 451-452; ov. 167-168. 
eene warme vooropzetting van datgene waarom het ons eigenlijk vóór alles te doen scheen, althans dat dit het uitgangspunt voor het verlangen naar eene herziening der contracten van 1814 geweest was, sprak uit die artikelen wel niet; maar daarin school nu eenmaal de fijne zet van de door ons voor te wenden achterhoudendheid: wij moesten doen of het ons eigenlijk ook niet kon schelen! Mannen als Canning waren echter met dergelijke kleine middelen niet te verschalken. Kwamen "andere of meer uitgestrekte" ruilingsontwerpen van Engelsche zijde ter tafel, dan moesten, gelastte art. 13, gevolmachtigden zich onbevoegd verklaren om zonder nader order hierop in te gaan, waarbij bovendien als volstrekte voorwaarde werd gesteld: "dat daarin niets zal worden gevonden nadeelig voor het ontzag, dat de inlandsche vorsten en volken voor het Nederlandsch gebied behooren te hebben, noch strijdig met de Onzentwege met dezelve gesloten verdragen". Daartoe werd speciaal, blijkens art. 8, ook gerekend het niet-afstaan van Singapore, behoorende aan onzen vazal, den sultan van Linga $(a)$. - Art. 9 verwierp alle denkbeeld van uitsluiting en monopolie-zucht, zoowel voor het verledene, na het herstel van ons gezag, als voor de toekomst; gevolmachtigden moesten ook de regelingen van Raffles en van het Britsch bestuur in Bengalen met die van ons doen vergelijken (art. 10); wilden echter de Engelschen bij hunne "werkelijk gerezene of slechts voorgewende bekommering" ten deze blijven, dan hadden gevolmachtigden de bevoegdheid om door eene stellige belofte in het te sluiten tractaat die vrees voor onze handelsbedoelingen te doen wegnemen (art. 11). Zóó kwamen er later allerlei tegen ons gerichte verzekeringen voor den dag, die feitelijk niet tepas kwamen. Waar wij op den voorgrond stelden, dat Raffles slechts onwaarheid sprak, had er geene quaestie van mogen zijn, dat wij niettemin waarborgen zouden leveren, alsof de beschuldigingen gegrond waren geweest. "Eene stellige verzekering" van Britsche zijde, "om het verblijf van den heer Raffles in het oostelijk gedeelte van Azië zooveel mogelijk te bekorten", zou daarentegen, herinnerde art. 14, onze Regeering met "welgevallen" vernemen. Voor het geven van dergelijke verzekering bedankte de tegenpartij echter wel degelijk. In plaats daarvan zullen de Nederlandsche gevolmachtigden het eindelijk goedvinden, als verklaard wordt, dat Engeland steeds eerlijk jegens ons had gehandeld!! - De twee volgende bepalingen brachten ten slotte in herinnering, dat eene eventueele overeenkomst nog door

(a) Zie dit art. 8 in Singapore I 430 ; ov. 42. 
de Volksvertegenwoordiging goedgekeurd zou moeten worden; dat aan de gevolmachtigden steeds de benoodigde stukken ter beschikking stonden; eindelijk dat "een algemeen rapport" van onze gevolmachtigden later werd tegemoet gezien. Het is jammer genoeg, dat het opmaken van zulk een stuk nooit plaats vond.

Elout vertrok medio Juli 1820 met zijn gevolg naar Londen, waar hij den $17^{\mathrm{n}}$, blijkens zijn schrijven van den volgenden dag aan Van Nagell, den Engelschen gevolmachtigden werd voorgesteld $(a)$. Toen hij den $19^{\mathrm{n}}$ zijne opwachting bij den Koning makte, betuigde Zijne Majesteit, schreef Elout den $21^{\mathrm{n}}$ aan Van Nagell (b), "voor onzen beminden Koning de hartelijkste vriendschap en genegenheid te voeden, terwijl Zijne Majesteit hierover in een zeer gemeenzaam gesprek met mij meer uitwijdde." Van Nagell antwoordde, dat het hem bijzonder aangenaam was het te beurt gevallen vriendelijk onthaal te vernemen, "en dat UHEG. zoo overwaardig is", luidt het in pruikenstijl $(c)$.

Misschien kon het betoon der vorstelijke welwillendheid eenigszins tot vergoeding strekken voor de weinig betamelijke wijze, waarop de Londensche bladen tegen ons uitvielen, zoodra Elout's komst publiek werd. Als altijd, Times voorop; doch daaraan voegde zich Morning Chronicle, een blad, schoon met kleiner oplaag, zoo mogelijk nog hooger in aanzien dan het City-orgaan $(d)$. Niet, dat men het tegen den oud-Commissaris-Generaal persoonlijk had; integendeel, men noemde hem veeleer "a man of sense and equity", "a gentleman of probity and talent"; maar men nam de gelegenheid waar om uittevaren tegen ons Indisch beheer en tegen Castlereagh's domheid wegens de teruggave onzer koloniën in 1814. Wèl bleek het door Raffles en de zijnen uitgestrooide zaad welig te hebben getierd. Wij deden niets anders, heette het in die smaadredenen $(e)$, dan in den

(a) „Ik wil dezen post niet laten vertrekken zonder Uwe Excellentie te melden, dat ik morgen bij den Koning ter audientie zal worden toegelaten, en dat naar het zeggen van den heer Canning onze conferentiën dadelijk zullen beginnen; ik ben gisteren door den ambassadeur Fagel in kennis met dien Minister gekomen en zal straks met Z. E. een bezoek bij lord Castlereagh afleggen, dien ik gisteren een oogenblik in het Lagerhuis gesproken heb.

"Ik heb met den baron Fagel Zijner Majesteits instructie doorgeloopen en over sommige punten eenige ophelderingen gegeven. Z. E. had geene bedenkingen op het een of ander." (B. Z.)

(b) B̈̈jdr. E. 91.

(c) Bïdr. E. 91-92.

(d) Walpole I 383.

(e) Zie de dagbladartikelen in Bïdr. E. $94 \mathrm{vv}$. 
Archipel overal de hand op te leggen en de Engelschen uit te sluiten: hen te weren, die met een paar duizend soldaten in weinige dagen wederom al de Nederlandsche bezittingen konden hernemen; en - zoo insinueerde men steeds door - was het waar, dat onze gevolmachtigden er vooral prijs op stelden met den vriendelijken Castlereagh te doen te hebben, reden te meer, meenden deze politieke tinnegieters "that such a preference would furnish a very powerful reason for not taking the conduct of these critical questions away from Mr. Canning".

De lezer make hieruit niet de gevolgtrekking, dat Canning tegenover onze gevolmachtigden als een anti-Nederlandsch gezinde dwarsdrijver optrad. Het is waar, Fagel was met Castlereagh zeer intiem $(a)$; maar Canning bleek een niet minder aangenaam en een evenzeer naar argumenten luisterend man van de wereld te zijn, zoodat als, tengevolge van Castlereagh's dood, diens plaats door zijn mededinger wordt ingenomen, zoomede Falck eerlang als Nederlandsch gezant te Londen optreedt $(b)$, men dan tusschen deze en Canning dezelfde vriendschappelijke verhouding vindt als tusschen hunne onmiddellijke voorgangers had bestaan. Slechts woorden van vereering had dan ook Falck voor den grooten staatsman. "Met Canning zoudt gij nog hooger loopen, mijn vriend", schreef hij Van Lennep, "indien gij hem van nabij in zijne eenvoudigheid, ik meen onopgesmuktheid, en in zijne loijale wijze van spreken en handelen zien mogt" $(c)$. Elout deelde die gevoelens en beiden betreurden zijn afsterven in 1827 evenzeer, "wiens verlies u misschien meer dan iemand in Nederland gẹfrappeerd en bedroefd hebben zal", betuigt Falck terecht, ook bij de herinnering aan Elout's samenkomsten met den overledene in Juli $1820(d)$. Inderdaad, die loyale wïze van spreken en handelen heeft meermalen Fagel en Elout met groote waardeering naar Holland doen schrijven. "De heer Canning trad in bijzonderheden, tot welker mededeeling aan ons hij zekerlijk niet gehouden was", berichtten zij dd. 28 Juli 1820 aan Buitenlandsche Zaken, in welk schrijven zij tevens verklaarden recht te moeten doen aan de openhartigheid, waarmede hij de zaken behandelde $(e)$; en minister Falck, die den Britschen minister ook als een zeer driftig man

(a) Verg. Fagel's Ontslag 403; ov. 11.

(b) Verg. Fagel's Ontslag noot op bl. 395 ; ov. 3.

(c) Falck's Brieven 261.

(d) Falck's Brieven 275.

(e) Bïdr. E. 129. 
kende (a), schreef den $1^{\mathrm{n}}$ Augustus uit 's-Gravenhage aan Elout met gelijke waardeering, hoezeer hem "de bedaardheid van den Engelschen negociateur" in de hand viel (b). Vol hoop op eene gunstige uitkomst, waar zulk een man met onze gevolmachtigden vooral werkzaam zou zijn - "never existed such a man as Canning", was ook het oordeel van den staatsman George Bentinck $(c)$ - getuigden zij reeds in hun eerste rapport van 21 Juli 1820 over den vermoedelijken uitslag der werkzaamheden, aan het slot: "dat de wijze, waarop de onderhandelingen begonnen en tot nu voortgezet zijn, ons bij uitnemendheid geschikt voorkomt om zelfs de teederste en neteligste punten openhartiglijk en vertrouwelijk te behandelen" $(d)$. Doch hoe is het met het allerteederste en neteligste punt eindelijk gegaan, welteverstaan met de Singapore-quaestie? De Britsche regeering wilde nu eenmaal niet het zoo schoon gebleken punt klakkeloos opgeven: dat was aan onze vertegenwoordigers voldoende duidelijk gebleken; maar Canning zette een oogenblik, doch ook slechts voor een oogenblik, de deur op een kier, waardoor wij er wellicht zouden kunnen komen: hij stelde een plaatselijk onderzoek naar de door ons beweerde rechten voor en beloofde, zwart op wit, dat men ons de haven zou teruggeven, indien de onaantastbaarheid dier rechten bleek! 't Is waar, dan was de uitslag nog niet zeker, vooral zoo men met oneerlijken als een Raffles te doen kreeg; doch Canning en Castlereagh beiden waren in ieder geval van gansch ander hout gesneden; en bovendien, het was de éénige uitweg, de éénige kans van succes, die ons werd aangeboden. Die wierpen wij echter weg, om de futiele reden, dat zulk eene zaak niet te Batavia, doch te 's-Gravenhage of te Brussel behoorde .... O doctrinaire Elout! $(e)$

Gelijk reeds uit het vorenstaande eenigszins blijkt, hadden onze gevolmachtigden vooral met Canning te doen. De heer Elout van Soeterwoude, de bezorger der papieren van den oud-commissarisgeneraal, schrijft dit toe aan het geschetter der Londensche bladen tegen Castlereagh's meegaandheid; dat kan natuurlijk wel, ook al wordt hiervoor verwezen naar dagbladartikelen, die eerst den $31^{\mathrm{n}}$ Juli en den $3^{\mathrm{n}}$ Augustus 1820, dus lang na het openen der

(a) Singapore II 374 ; ov. 62.

(b) Bijdr. E. 153.

(c) Greville 57.

(d) Bïdr. E. 110.

(e) Zie de belangrijke bijzonderheden in Singapore I 434 ; ov. 46 en wat daaraan voorafging en volgde. 
onderhandelingen verschenen $(a)$. Ik zou het echter in meer voor de hand liggende redenen zoeken.

Vooreerst zij herinnerd, dat in de geschillen over de Koningin, Canning meer op haar hand was, in afwijking dus van de overige leden der regeering. In vroegere jaren verkeerde hij in haar intiemen vriendenkring en gevoelde hij zich door hare eigenaardige manieren aangetrokken. Hij vergat dien tijd niet, nu de vrouw in moeilijkheid bleek te zijn op beschuldigingen van de regeering, wier lid hij was. Tegen het weglaten van haar naam uit het gebedsformulier had hij reeds bezwaar gemaakt, zij het ook onder eenig voorbehoud; ook toen, vò̀r de poging tot vergelijk, het voor haar bezwarend dossier in het Heerenhuis ter sprake kwam en Castlereagh eene schoone redevoering hield, verdedigde Cauning nog wel het ministerie, tot zoover als de zaak gegaan was, doch uitdrukkelijk verklaarde hij tevens nooit als haar beschuldiger te willen optreden. De gebeurtenissen leidden er echter toe, dat het ministerie zich beschuldigend moest doen hooren; Canning, zijne belofte getrouw blijvende, kwam dientengevolge in eene positie, waardoor hij geene enkele partij meer bevredigde en natuurlijk zich van Castlereagh verwijderde $(b)$. Het moet dus voor beide mannen minder aangenaam

(a) Bijdr. E. bl. XIX. - Men leze ook den volgenden uitval in de Fragments of voyages and travels van zekeren kapitein Basil Hall, verschenen na het tractaat van 1814, waarbij Java aan ons overging; een uitval, dien men vindt opgeteekend in Brieven-Hogendorp V, 201: "I had previously visited alone about seven hundred miles of the interior of that noblest of all our insular possessions in the East. It is truly grievous to think how unwittingly we allowed that magnificent possession to slip through our fingers in 1814, at the grand settlement of affairs. But after the downfall of Buonaparte such a game of chuck farthing was played with kingdoms, that even a gigantic country like Java failed to excite its due share of notice, or was totally lost sight of in the haze which obscured every thing at a distance from the scene of excitement."

(b) "The speech which Canning made on the occasion of the King's message", teekende Greville in zijn dagboek ad 16 Juni 1820 op (Greville 29-30) „has been violently attacked by all parties, and is said to have given as great dissatisfaction to the Queen as to the King. It is not easy to discover what the Queen could have objected to in the speech, for it was highly favourable and flattering to her. It was generally supposed last Sunday that he would resign in the course of the week, and bets were laid that he would not be in office next Sunday." - De hier bedoelde redevoering werd door Canning gehouden den $7^{\mathrm{n}}$ Juni, gevolgd door eene op den $22^{\mathrm{n}}$. Zie het aangehaalde IV deel van de Speeches, bl. 229 en 255. Men leest o. a. in de eerste redevoering (bl. 252): "Had it been in his power to avoid the call of duty, he would rather have been any where than where he was, when the subject 
geweest zijn om onder de versche indrukken van zulk eene verdeeldheid dagelijks in eene kleine vergadering samen te werken. Doch ook eens aangenomen, dat dit geen ernstig bezwaar opleverde, de overkroppende werkzaamheden, waarmede Castlereagh belast was, en het zenuwleven, dat deze overlading tengevolge had, kunnen als afdoende verklaring voor de beperkte onthouding worden aangenomen. Bovendien, zoo beide gevolmachtigden voor de beslissing der hoofdzaken noodig waren, voor de technische uiteenzetting der bijzonderheden was Canning, als president van den Board of Control, waardoor met vele Indische deskundigen voeling kon gehouden worden, geheel voldoende. $\mathrm{Wij}_{\mathrm{ij}}$ zien dan ook dezelfde regeling eenige jaren later treffen, wanneer de samenkomsten hervat worden en er geene aanleiding meer voor de dagbladen is om op een der beide hier angewezen Britsche gevolmachtigden af te geven, noch voor verwijdering tusschen de dan optredende mannen, met name Canning, minister van Buitenlandsche Zaken, en $W y n n$, president van den Board of Control: ook dan toch worden de eerste werkzaamheden en vergaderingen alleen aan Wynn van Britsche zijde overgelaten.

De werkzaamheden begonnen alzoo, zonder medewerking van Castlereagh. De eerste samenkomst werd dd. 18 Juli 1820 gehouden en daarop, blijkens het rapport van dien dag door Fagel aan Buitenlandsche Zaken gezonden, afgesproken, dat partijen elkander de punten zouden mededeelen, waarover de besprekingen konden loopen $(a)$. Van Engelsche zijde bood men dientengevolge een lijstje

first came to be agitated elsewhere, and during the present debate. Towards the illustrious person who was the object of the investigation, he felt an unaltered regard and affection - if he might use, without impropriety, so ardent a term. Gladly would he have rendered her any service; and there were no efforts he would have spared, no sacrifices he would not have made, to have prevented the necessity of such a proceeding as the present against her."

(a) "Le résultat de notre entretien de ce matin avec lord Castlereagh et d'une longue conférence de plus d'une heure et demie que nous avons eu ensuite, Mr. Elout et moi, avec Mr. Canning, est que des deux côtés on dressera une espéce de note ou d'état nominatif des principaux points à discuter. Après avoir échangé ees notes demain nous nous réunirons de nouveau après demain, Mr. Elout, Mr. Canning et moi. De ce:te manière on aura pour ainsi dire établi le point de départ, en on aura reconnu le terrain. Il a été convenu que ce ne sera qu'après que cet objet préliminaire aura été rempli que lord Castlereagh se joindra à nos conférences. Celle de ce matin, en posant les premiers fondemens de l'ouvrage et en mettant Mrs. Elout et Canning en rapport ensemble, a été très-satisfaisante." (B. Z.) 
van 14 onderwerpen aan, doch zonder eenige toelichting of uitwerking, als "Rhio", "Singapore", "Chinsurah", Bernagore, Calcapore, Fultha etc." De Nederlandsche nota leverde door grootere uitvoerigheid eene betere basis tot bespreking, natuurlijk echter zonder ruilingsvoorstellen, wijl men Engeland eerst uit den hoek moest doen komen. (a)

De nota's werden den $20^{\mathrm{n}} \mathrm{Juli}$, op de tweede bijeenkomst, het onderwerp van vertrouwelijk gesprek. Onze aanspraak op Billiton, als onderhoorigheid van Banka, werd alvast dadelijk van de hand gewezen; de geldelijke vorderingen zagen wij evenzeer door Canning belangrijk beperkt; maar dezerzijdsch betoog tegen de bezetting van Singapore maakte zoo'n indruk, dat de Britsche gevolmachtigde zich verplicht zag om het recht daar te laten, er echter de aandacht op vestigende: "dat deze geheele zaak in de opinie van het Britsch publiek eenig gewigt verkregen had, hetgeen de zaak van eenen bijzonderen aard had doen worden". Het ontlokte aan onze gevolmachtigden het geschikte antwoord: "dat ook het Nederlandsch publiek over al het gebeurde in de Indische zeeën een aandachtig oog geslagen had" (b). De lezer weet echter hoe bitter weinig dat Nederlandsch publiek destijds en later op Indische zaken warm liep $(c)$. — De waarde onzer factorijen in Vóór-Indië werd breedvoerig door ons betoogd; nochtans tevens te kennen gegeven, dat wij desnoods wel zoo goed zouden willen zijn er "door minnelijke schikking" van af te zien $(d)$.

Toen men aldus den ganschen omvang der zaken voorloopig beredeneerd had, sprak men af, dat Canning eene ontwerp-overeenkomst zou schetsen, waardoor men eene gemakkelijker basis van beraadslaging had (e). De Britsche gevolmachtigde beloofde het werk binnen een uur te zullen gereed hebben, waarna men recht voldaan uit elkander ging.

Canning ondervond echter, dat het ontwerpen van tractaten zóó gemakkelijk niet ging. In plaats van binnen een uur het beloofde op den $20^{\mathrm{n}}$ te leveren, was het eerst den $22^{\mathrm{n}}$ gereed. Het stuk werd met een vriendelijk briefje onzen gevolmachtigden aan-

(a) De Engelsche en Nederlandsche nota's in Bijdr. E. 100 vv. - Zie ook Factorijen II 452 ; ov. 168.

(b) Zie breeder in Singapore I 431-432; ov. 43-44.

(c) Verg. Sluiting $252 \mathrm{vv}$; ov. $14 \mathrm{vv}$.

(d) Zie breedvoerig in Factorïen II 452-453; ov. 168-169.

(e) Zie hierover breeder in Factorijen II 453-454; ov. 169-170. 7• Volgr. II. 
geboden $(a)$; zij moesten het, werd herinnerd, geenszins als een officieel voorstel beschouwen, doch slechts als een grondslag van behandeling; het had meer omvang gekregen dan oorspronkelijk gedacht was, doch deze uitbreiding heette "chiefly as you will observe to your advantage". Ziehier een overzicht van het in ieder geval belangrijke stuk (b).

1. Afkeuring van Raffles' aanhouden van Padang; 2. Engeland maakt geene aanspraak op de Lampongs $(c) ; 3$. Verwerping van Raffles' contracten, "without authority" gesloten met de hoofden van Menangkabau enz. tot afstand van grondgebied; 4. Ontzegging van Nederlands recht op Billiton, doch bereidverklaring het toe te kennen in ruil van Singapore $(d) ; 5$. Erkenning overigens van onze souvereiniteit over den Riouw-archipel; 6. Mede erkenning van onze Borneo-contracten : "being found not to contain any article excluding British trade"; 7. Belofte over en weer, dat men de contracten in de Oostersche zeeën met inlanders aan te gaan, elkander zou laten zien en dat men er geene bepalingen in zou opnemen tot uitsluiting der wederpartij van den handel: - eene bepaling, welke eerlang art. 3 al. 2 van het tractaat zou worden, doch die men onzerzijds had moeten verwerpen, wijl wij het niet waren geweest, die zulk een voorschrift wenschelijk deden zijn en het in de Oostersche zeeёn vooral eene verplichting maakte, tegen ons gericht; 8. Behandeling over en weer op den voet van meest begunstigde natie; 9 . Verbod elkanders vlag op de schepen te gebruiken $(e) ; 10,11,12$. Eene commissie benoemen voor het uitmaken der wederzijdsche geldelijke vorderingen, Canning aannemende, dat het verschil was "due to the British Government", voor de kwijting waarvan hij echter verklaarde genoegen te nemen met Banka en Fultha, terwijl dan bovendien Engeland beloofde af te zien van Singapore $(f)$ : - voorwaarden vrij wat voordeeliger dan het betalen door ons van f 1.200.000 en het gansche verlies van Malakka met Singapore, zooals later is bepaald geworden, terwijl wij de resteerende factorijen in Hindostan nog voor de Engelsche factorijen in Benkoelen ter ruiling konden

(a) Een en ander in Bijdr. E. 110.

(b) De artikelen van het ontwerp ook bij Smulders, in hun geheel op bl. 157 vv. en in substantie op bl. $39 \mathrm{vv}$. - Men zie mede De Sturler 211 vv.

(c) Verg. Lampongs.

(d) Zie dit artikel in Singapore I 432; ov. 44.

(e) Zie Palembang 507; ov. 177.

(f) Zie Factorijen II 454; ov. 170. 
aanbieden; doch de tin trok ons te zeer aan, ofschoon eerlang Malakka zelf op dat gebied groote voordeelen zou geven; $13 \mathrm{t} / \mathrm{m}$ 19. Over onze factorijen in Vóór-Indië $(a) ; 20$. Beperking der slavernij; eindelijk 21, dat het "vergeven en vergeten" zou uitgesproken worden omtrent al hetgeen te Palembang was geschied.

$\mathrm{Nu}$ overeenkomstig onze eigen wenschen, van Engelsche zijde flinkweg voor den dag was getreden, zou men allicht verwacht hebben, dat de Nederlandsche gevolmachtigden punt voor punt hadden aangenomen, verworpen, vervangen, nadat het door hen den $23^{\text {n }}$ Juli was bestudeerd. Misschien geschiedde dit ook wel mondeling op de conferentie met Canning, die den volgenden dag plaats vond; doch een feit is het, dat men onzerzijds een tegenvoorstel ontwierp, dat zich in het geheel niet naar het ontwerpCanning richtte $(b)$; hierdoor werd het overzicht niet slechts verbroken, doch kregen de zaken tot ons nadeel een geheel ander aanzien ten slotte. Met het tegenvoorstel is dan ook de zaak verknoeid geworden.

Voor de artt. 1, 2, 3, 4, 6 en 21 luidde het terecht bij de eerste zinsnede van art. 1 meer algemeen, dat de Britsche regeering niet erkende de contracten enz. harer agenten, wederrechtelijk ten koste der Nederlandsche macht gesloten en verder dat Singapore zou ontruimd worden; art. 2 bood Fultha aan voor de erkenning van ons recht op Billiton $(c)$. Den voorgestelden ruil Singapore versus Billiton verwierpen wij dus; dit laatste eiland mochten trouwens gevolmachtigden volgens hunne instructie niet eigenmachtig laten ontglippen; ook wilden wij derhalve niet weten van den afstand der factorij Fultha en van Banka tegen kwijtschelding onzer schuld aan Engeland; dat ging op het oogenblik al even bezwaarlijk, waar onze gevolmachtigden beweerden, dat Engeland schuldenaar was. De voor ruiling bestemde plaatsen - Benkoelen noemden we nog volstrekt niet - moesten, overeenkomstig stellige bevelen, onverwijld worden overgegeven (art. 3). — Erkenning onzer Borneo-contracten wilden wij onzerzijds terecht niet gedoogen. Engeland had er geene bemoeienis mede; maar, volgens art. 4, zouden beide partijen de met inlanders gesloten contracten eerbiedigen en geene bepalingen van uitsluiting inhouden. - Behandeling op den voet van meest begunstigde natie over en weer werd door art. 5 aangenomen; alleen zonderde

(a) Zie in het breede Factorijen II 454-455; ov. 170-171.

(b) Opgenomen in Bijdr. E. 115 vv. - Bij Smulders in substantie 40-41. Men zie ook De Sturler 211 vv.

(c) Zie beide artikelen in Singapore I 432-433; ov. 44-45. 
men van de handelsvrijheid uit de Molukkengroep, "jusqu'à l'époque où le Gouvernement des Pays-Bas jugerait à propos d'abandonner la monopole des épiceries". - Het punt om op de schepen desnoods de vlag der wederpartij te gebruiken, werd niet aangeroerd. - Tegen het brengen der geldelijke vorderingen bij eene speciale commissie maakten onze gevolmachtigden bezwaar. Men kan zich dit wel voorstellen; doch wanneer wij spoedige oplossing der staatkundige quaestiën verlangden, en die was immers vò̀r alles noodig, dan mocht Canning's voorstel lang niet verwerpelijk geacht worden. Lezen wij toch de Nederlandsche ontwerp-artikelen $8 \mathrm{t} / \mathrm{m} 15$ over deze ingewikkelde aangelegenheid, dan zien wij hoeveel voetangels en klemmen er in lagen; bijna gaven onze gevolmachtigden op dit gebied niets prijs. Alleen stonden wij toe den eisch, voortgevloeid uit Daendels' handeling, waarbij hij de ingezetenen tot geldafstand had gedwongen tegen aanneming als pand van gouvernementsproducten enz., opgeslagen in de magazijnen, doch die bij de verovering van Java door de Engelschen voor goeden prijs waren verklaard. Commissarissen-Generaal hadden beweerd, dat die goederen aan particulieren behoorden en dat dus Engeland de waarde er van diende terug te geven $(a)$. Behalve nu, dat onze gevolmachtigden hiervan afzagen, luidt het overal in het Nederlandsch ontwerp: Le Gouvernement Britannique "reconnait", "en outre s'engage", "s'engage encore", "reconnait", "renonce", "s'engage". Geheel Elout; maar men zou ons zien aankomen! - Voor de in het Engelsch ontwerp aangenomen salpeter- en opiumleveringen aan Nederland stelde art. 16 eene nader te bepalen geldsom, omdat we gaarne het belang van het Britsche gouvernement wilden bevorderen, luidde de lievigheid (b). De lezer van mijne Elout-verhandeling behoeft wel niet te vragen, wie deze franje er weder aanbracht. - De vroeger ons betwiste jurisdictie, parelvisscherij, zoutpannengeschiedenis in Hindostan, gelijk een en ander door het Canning-ontwerp toegestaan waren, werden natuurlijk aangenomen (artt. 7, 17, 18); evenzoo de voorgestelde maximumbepaling betreffende differentieel recht (art. 6). Het anti-slavernij-artikel, hetwelk speciaal Banda betrof, werd terecht door ons verworpen, als in het te sluiten tractaat niet op zijne plaats; doch wel herinnerden wij bij een art. 19 aan Engelands verplichting tot betaling der jaarlijksche som voor Bernagore $(c)$.

(a) Zie Elout 241; ov. 13.

(b) Zie het artikel in Factorïen II 456; ov. 172.

(c) Verg. hoofdstuk V Factorijen II. 
De bijeenkomst van 26 Juli werd vooral door de Singapore-quaestie ingenomen $(a)$. De besprekingen leidden er toe, dat in den namiddag van den volgenden dag Canning een ander ontwerp ter tafel bracht (b). Het bevatte in substantie de volgende artikelen: 1. Geene uitsluiting; behandeling als meest begunstigde natie; 2. Engeland neemt de Molukken-uitzondering aan; 3. Eerbiediging van inlandsche contracten; 4, 5, 6. Singapore wordt ons afgestaan, indien ons recht bij nader onderzoek blijkt; kwam het tot dien afstand, dan zouden wij Engeland ter beschikking stellen "some naval station, eastward of the straits of Malacca, fit for the harbouring and refitment of British ships of war and merchantmen, the occupation where of may not give ground for any contestation or interference"; als Billiton daarvoor niet geschikt bleek, dan stond Engeland het ons af, waartegen wij zouden prijs geven Fultha en Calcapore $(c) ; 7$. Verzekering van handelsvrijheid, belofte over en weer tot bestrijding der zeerooverij; 8. Het verbod om elkanders vlaggen te gebruiken $(d)$; 9. Differentieele rechten; 10. Handhaving van de vroegere voorstellen over opium- en salpeterleveringen aan ons; 12, 13, 14 . Idem betreffende zoutpannen, parelvisscherij en jurisdictie in Hindostan; 15. Idem van Canning's vroeger voorstel over eene nadere commissie tot onderzoek der wederzijdsche geldelijke vorderingen, echter nu met weglating van het due to the British Government; 16. De conventie wordt slechts aangenomen voor 14 jaar, in verband met het ten einde loopen van het octrooi der Oost-Indische Compagnie, zoo het dan niet vernieuwd werd; eene zonderlinge bepaling, die Canning dadelijk liet vallen op de aanmerking onzer gevolmachtigden, dat beide zaken in geenerlei verband met elkander stonden; eindelijk 17: "buried in oblivion" de vroegere twisten.

Als men bedenkt, dat onze gevolmachtigden het voorstel om over Singapore tot eensgezindheid te komen, op eene bijna onverantwoordelijke wijze verwierpen $(d)$; dat zij evenzeer vast besloten waren niet de kans te loopen Billiton te verliezen, dan zal de lezer erkennen, dat de onderhandelingen al heel weinig vorderden $(e)$.

De zitting van den $28^{\mathrm{n}} \mathrm{Juli}$ begon met geene bijzondere gezichtspunten op te leveren. Singapore was de hoofdschotel blijven uitmaken;

(a) Zie Singapore I 433 ; ov. 45.

(b) In $B \ddot{y} d r . E .122$ vv.

(c) Zie Factorïjen II 456; ov. 172.

(d) Zie Singapore I 433-436; ov. 45-48.

(e) Zie over de voorgestelde Billiton-ruiling nader Factorïen $\amalg$ 456, ov. 172. 
Canning had het diepgaand betoog van gouverneur-generaal Van der Capellen over het wederrechtelijke dier bezetting teruggegeven, welk stuk onze gevolmachtigden hem ter hand hadden gesteld, zonder bevorens in het Britsche voorstel tot onderzoek der rechten te treden; eene verkeerdheid, waarop door mij elders is gewezen $(a)$. $\mathrm{Nu}$ was het te laat en zagen de Britsche onderhandelaars in, dat het behoud van Singapore met geen schijn van recht kon worden gevorderd, zoodat een onderzoek ten hunnen nadeele moest uitloopen, terwijl enkel het goed recht door den tijd als voldongen feit moest worden voorgesteld. Er zat niets anders op - daar het voor deze verjaring nu nog te vroeg was - dan dat de onderhandelingen onbepaald werden verschoven, gelijk weldra zou geschieden.

Den $29^{\text {n }}$ Juli woonde ook Castlereagh de vergadering bij, voor de eerste.... en voor de laatste maal! De Britsche minister sprak van de behoefte aan een vast punt en over de wenschelijkheid der benoeming van consuls; verder van ons streven naar uitsluitend gezag $(b)$. Onze gevolmachtigden wederlegden de behoefte aan een vast punt, met de opmerking dat de Engelschen dan toch reeds Benkoelen en Poeloe Pinang bezaten; doch dit scheen hen niet te voldoen. Niets was men alzoo verder, toen Castlereagh de vergadering verliet. Onze gevolmachtigden, nu weder met Canning alleen gelaten, wisten daarop behendig den Britschen minister er toe te brengen, ons Benkoelen als ruilingsmiddel an te bieden; doch dit was, als het eene overwinning mocht heeten, het énige lichtpunt; want reeds op die vergadering werd slechts overeengekomen, dat de Singaporequaestie niet andermaal zou worden opgenomen, voordat door de Engelsche regeering zouden ontvangen zijn "de berichten van den Gouverneur-Generaal van Britsch-Indië over den laatsten brief van den Nederlandschen Gouverneur-Generaal, geschreven op 16 December 1819 " $(c)$.

Hadden onze gevolmachtigden terstond Canning's eerste voorstel van 22 Juli 1820 tot basis van onderhandelingen, zonder onoprechtheden aangenomen, de min beduidende zaken ter zijde latende, enkel om te beginnen de hoofdpunten aanvallende, wij zouden het hart van de wederpartij hebben gewonnen, door de overtuiging te schenken, dat binnen de grenzen van billijkheid, toenadering wel

(a) Singapore I 434-436; ov. 46-48; zie echter vooral daar het oordeel van het Engelsche bestuur er over op bl. 439-440; ov. 49-50.

(b) Zie Factorijen II 456-457; ov. 172-173.

(c) Zie breeder Singapore I 437; ov. 49. Er staat daar de drukfout 1828, als jaartal van het rapport onzer gevolmachtigden van 1 Augustus 1820. 
en ter dege mogelijk bleek; te eerder zou men daarin wellicht geslaagd zijn, omdat de binnenlandsche politieke moeilijkheden de Engelsche gevolmachtigden tot haastige afdoening drongen, die hun zeker ook wel wat waard zou zijn geweest. $\mathrm{Nu}$ de zaak toch verknoeid bleek, kwam de Singapore-stichting weder met haar volle gewicht naar voren. De Britsche onderhandelaars gevoelden te zeer, én dat hier een onrecht was begaan, én dat het ernstig bezwaar had, dat weer ongedaan te maken. Dat men van onze zijde er ooit toe zoude komen vrijwillig Malakka op den koop toe te geven, werd destijds zóó weinig voorzien, dat men het zelfs van Britsche zijde niet eens heeft wagen te opperen. Daartoe moest eerst ook in onze oogen die schoone bezitting waardeloos gemaakt zijn of althans waardeloos gemaakt schijnen, onder het licht der toenemende ontwikkeling van Singapore! In ieder geval, wij, niet zij, ondervonden schade en schande door de zaken nu maar voor onbepaalden tijd hangende te laten. Het afwachten van nadere berichten uit Bengalen, waarnaar intusschen niet van Britsche zijje te Calcutta gevraagd werd! zag men alzoo aanvoeren als eene met hinderlijke onbeschaamdheid voorop gezette reden tot uitstel van langen duur; de zucht van een der Britsche gevolmachtigden om eene buitenlandsche reis te maken, eene tweede reden, die de eerste, zoolang zij duurde, begon te versterken. Ziedaar wat zou worden van het vol illusiën door Fagel en Elout bij den aanvang der onderhandelingen aan Buitenlandsche Zaken geuit vertrouwen: "dat de wijze waarop de onderhandelingen begonnen en tot nu voortgezet zijn, ons bij uitnemendheid geschikt voorkomt om zelfs de teederste en neteligste punten openhartiglijk en vertrouwelijk te behandelen".

Handig, bijzonder handig en netjes, was de wijze, waarop de Britsche gevolmachtigden de onderhandelingen deden doodloopen. Den $4^{\mathrm{n}}$ Augustus werden door partijen vriendelijke nota's gewisseld, houdende dat men elkaar, na ontvangst van de Bengaalsche berichten, in October 1820 zou terugzien (a). Men gaf een overzicht van hetgeen verricht, erkend, min of meer aangenomen kon heeten $(b)$, en den $5^{\mathrm{n}}$ werden door de vier gevolmachtigden vier artikelen onderteekend, die de strekking hadden, de vrijheid van handel te waarborgen. Daaraan was eene Pro memorie gehecht, houdende, dat als besliste punten werden beschouwd:

(a) Zie Singapore I 438-339; ov. 50-51.

(b) Zie Bijdr. E. 139 vv. 
a Afkeuring van het gedrag der Engelsche agenten;

$b$ Vrijheid van handel, met uitzondering van de Molukken;

$c$ Eerbiediging van de vrije vaart;

$d$ Wederkeerige mededeeling van de verdragen, met de inlandsche staten te sluiten.

Als onbeslist nam men aan:

a Singapore.

$b$ Billiton.

$c$ De quaestiën ten aanzien van onze factorijen in Vóór-Indië; over het gewicht waarvan onze gevolmachtigden nader vol illusie uitweidden $(a)$ !

$d$ De regeling der rechten van in- en uitvoer.

$f$ Onderdrukking van zeerooverij en het verbod van het misbruik maken door oorlogsschepen van de vlag der wederpartij; eene samenkoppeling "omdat" — rapporteerden onze gevolmachtigden aan Buitenlandsche Zaken in hun laatste verslag dd. 9 Augustus over de onderhandelingen $(b)$ — „de Britsche gevolmachtigden de wering van de zeerooverijen niet anders dan in verband met het verbod om de wederzijdsche vlag te voeren, wilden beschouwen en beoordeelen".

$g$ Zoutmonopolie. - Ons monopolie sloot natuurlijk vrijen handel in zout uit: vandaar bezwaar door de Engelschen ingebracht. "Tot verstand hiervan", lichtte het aangehaalde rapport in, "dient te worden aangeteekend, dat hetzelve alleen bij wege van pro memoria is aangehaald, om daarna over de ware strekking van hetzelve de noodige inlichtingen te geven."

$h$ Baros en Ajer Bangis.

$i$ De geldelijke aangelegenheden.

$j$ Eene Britsche vestiging in den Oost-Indischen archipel.

$k$ Toelating van consuls.

De beide laatste punten waren "op bijzondere begeerte van de Britsche gevolmagtigden" opgenomen.

Zoo scheidde men in vrede, na niets tot stand te hebben gebracht! "Er zal nu gelegenheid zijn”, besloten onze onderhandelaars hun rapport van 9 Augustus, "over dit en alle nog overige onderwerpen, bedaardelijk door te denken, en in zoo verre heeft dan het uitstel der onderhandelingen nog eenige nuttigheid." Wel wis en zeker!

(a) Zie Factorïen 458; ov. 174.

(b) Bïjdr. E. 147. 
"The undersigned will be prepared", verklaarde immers de wederpartij plechtiglijk, "to resume those conferences so soon as they shall be in possession of the Governor-General's report, which may be expected in the month of October"!!

Het afbreken der onderhandelingen vond weder een treurigen naklank in de Londensche bladen, die zich beijverden Nederlands verdediging der bij het tractaat van 1814 gewaarborgde rechten te beschimpen. Fagel vermoedde, gelijk hij dd. 15 Augustus 1820 aan den teruggekeerden mede-onderhandelaar schreef, dat Crawfurd er achter zat: "hetwelk, zoo zijnde, hem in mijne achting niet zoude doen rijzen", voegde hij er aan toe $(a)$. Doch wat gaven deze menschen om onze achting? De officieuse Courier van 14 Augustus 1820 , die wij reeds bij eene vroegere gelegenheid leerden kennen, toen Fagel daarin het schelden over Palembang trachtte te bestrijden, weersprak de beschouwingen van de Morning Chronicle over het uit elkander gaan der conferentie wegens Singapore, als "materially incorrect". Het was waar, liet men door de Courier verkondigen $(a)$, dat de onderhandelingen waren verschoven, ten einde nadere inlichtingen uit Indië over de jongste gebeurtenissen te erlangen: "but we believe that the character of the discussions, as far as they have proceeded, is quite different from that which has been ascribed to them by the Morning Chronicle, and that very friendly and liberal disposition was carried on both sides". Den volgenden dag kwam de Chronicle op de zaak terug. Als men nagaat, hoe besloten in zekeren zin de conferentiën gehouden werden, trekt het de aandacht, dat de Londensche bladen, de publieke opinie, waarmede men steeds tegen ons opkwam, goed ingelicht bleken. Wij hebben gezegd, herinnerde het blad $(a)$, dat de onderhandelingen gestaakt waren in afwachting van berichten uit Indië over de laatste handelingen van lord Moira, die vóór October a. s. niet kunnen verwacht worden: maar wat makte deze staking noodzakelijk? "The positive refusal of the Dutch agents to concede any one point that was asked, although at the same time they disclaim all pretence to the Sovereignty of the Archipelago. Wherever we attempt to fix on a station, they instantly set up a claim to it; thus, though they never had a footing at Sincapoor, we no sooner proposed to make it a resting place, than they alleged that it was theirs. And we see in the Vrai Libéral, that they accuse us of indulging in attempts at

(a) Bïjdr. E. 155. 
aggrandizement, though our most strenuous efforts were made for their deliverance from the Gallic yoke, and though we delivered to them back the Conquest of Java, with all our own Colonies put together."

Typische courantenschrijverij.

Directeuren der O. I. Compagnie te Londen haastten zich om bij brief dd. 8 Augustus 1820 aan het Bengaalsch bestuur het afbreken der onderhandelingen te berichten, terwijl zij de stukken over de plaatsgevonden conferentiën daarbij voegden $(a)$. Het schrijven is even uitvoerig als belangrijk. Zoo zien wij er uit, dat de ter conferentie aangevoerde betoogen tegen de beschuldigingen van onze zucht tot uitsluiting grooten indruk gemaakt hadden; immers er wordt in medegedeeld, dat de met Sambas, Mempawa en Pontianak gesloten verdragen $(b)$, door Elout overgelegd, de beschuldigingen afdoende schenen te wederleggen, zoodat zij nadere inlichting verzochten, daar men toch niet kon veronderstellen, dat die beschuldigingen geheel uit de lucht zouden zijn gegrepen. Dan wordt over Singapore en over Borneo gehandeld; van de vier voorloopig aangenomen artikelen geeft men kennis; verder komen lord Moira's handelingen ten opzichte van Raffles goedkeurend ter sprake. Eindelijk roert men aan het punt der Nederlandsche bezittingen in Vóór-Indië en men verzoekt aan de regeering te Calcutta, nooit na te laten om, met het oog op de te hervatten onderhandelingen, van alle gebeurtenissen, die hierop van invloed kunnen zijn, aanstonds bericht te geven. Uit deze mededeelingen omtrent Vóór-Indië blijkt, welke groote waarde de Compagnie aan den afstand onzer bezittingen aldaar hechtte; zij vroeg het advies over de hoegrootheid der daarvoor te geven som, dan wel over hare verkrijging door territoriale ruiling $(c)$.

Het slot van de depêche $(d)$ bevatte eene aanwijzing, waaruit wij zouden mogen opmaken, dat reeds destijds bij het Engelsche ministerie het opzet bestond om de belofte van met October 1820 de onderhandelingen te hervatten, niet na te komen; want men leest er in: "it is nevertheless possible that circumstances may occur further to protract these discussions". Dat schrijft de Directie den $8^{\mathrm{n}}$, terwijl haar voorzitter als gevolmachtigde een voor ons bestemd

(a) De brief is afgedrukt sub 62 Singapore I.

(b) Deze verdragen zijn afgedrukt bij Smulders 166 vv.

(c) Zie Factorïen II 459; ov. 175.

(d) Niet $\S 28$, gelijk is afgedrukt in Factorijen II 460, ov. 176, reg. 2 v. b., doch $§ 25$. 
stuk onderteekent vier dagen te voren, waarin staat, dat nog in October de onderhandelingen zullen hervat worden. Het was een wenk voor de Bengaalsche regeering om te zwijgen over het onderwerp, waaromtrent inlichtingen eerst moesten worden verkregen, ten einde de onderhandelingen te kunnen hervatten.

De Britsch-Indische regeering antwoordde bij depêche van 1 Maart $1821(a)$. Met welk eene rechtvaardigheid zij zich tot orgaan van Raffles' beschuldiging over de uitsluitingsdenkbeelden van Nederland gemaakt had, blijkt wel hieruit, dat men er niets anders op kon antwoorden, dan dat Elout zich tegenover Fendall had doen kennen als iemand, op wien niet viel te vertrouwen! Alzoo de Parthenpijl van een der leden van deze regeering, bestaande behalve uit den landvoogd Moira, uit de raadsleden Adam en Fendall (b).

In de drie volgende hoofdstukken zal de lezer kennis maken met het door Engeland aangenomen stelsel ter verschuiving van de onderhandelingen; een onderwerp, leerrijk genoeg, waarvan door Smulders op bl. $43-45$ eene onvoldoende teekening is gegeven.

\section{VIII.}

\section{Vergeefsche pogingen onzerzijds tot het einde van 1820 aangewend om Canning tot hervatting der onder- handelingen te brengen.}

Het afbreken der onderhandelingen bood Canning de door hem reeds uitgeziene gelegenheid aan, om voor een tijd Engeland te verlaten.

Gelijk medegedeeld is, had de minister bezwaar om in den strijd tegen de Koningin mede te doen, nu die door de tweede lezing op 17 Augustus 1820 van lord Liverpool's wetsontwerp stond geopend te worden. Geenszins geloofde hij haar onschuldig; doch, gelijk zoovelen zijner landgenooten, vervulde hem de zaak met weerzin, hem die, vóór de beschuldigde in 1814 het land verliet, een trouw bezoeker harer salons in Blackheath en Kensington geweest was, waar de vorstin een uitgelezen kring van mannen om zich heen zag, als Byron, Sheridan, Lawrence, enz. Eene goede, vriendelijke gastvrouw als zij toonde te zijn, gevoelde de minister zich tot haar aangetrokken, niettegenstaande de praatjes, die reeds destijds over haar liepen en waartoe zij door haar lichtzinnig gedrag ook vol-

(a) Het belangrijke stuk in bijl. 8 .

(b) Verg. Elout 236-237; ov. 8-9; Opvattingen 463, ov. 123, sub 130. 
komen aanleiding gaf $(a)$ - Toen nu de Koningin zoo onverwacht naar Londen was teruggekeerd, begrepen Canning's collega's wel de moeilijkheid zijner positie, doch zij drongen bij hem aan om te blijven; men zou hem zoo min mogelijk bij de zaak betrekken. Canning gaf toe en met het aangeboden en aangenomen vergelijk scheen alles in het effen te zullen komen. - Naw bleken echter ook deze onderhandelingen mislukt, of de minister had met den Koning een onderhoud, waarin hij zijn ontslag verzocht. Niets liever dan dat, meende George IV, die zich reeds lang aan de houding van zijn minister geërgerd had. Lord Liverpool wilde er echter niet van weten en bij het ontzag, dat de onwaardige vorst voor dien staatsman had, zag de Koning zich verplicht het verzoek te weigeren, "in spite of the very unwarrantable conduct of that gentleman in his place in Parliament", knorde het onkoninklijk. Canning gehoorzaamde; maar overeenkomstig de aangenomen toezegging, onthield hij zich van elke deelneming in het voorbereiden en behandelen der wet tegen de Koningin (b).

Zoo was het den $5^{\mathrm{n}}$ Augustus geworden, toen onze koloniale onderhandelingen werden afgebroken. Aanstonds aanvaardde Canning eene buitenlandsche reis, waardoor hem de gelegenheid werd gegeven, zich aan het pijnlijk proces geheel te onttrekken $(c)$. Augustus, Sep-

(a) Hoe weinig begrip van weIvoegelijkheid ze had, blijkt uit de paar woorden, die ze Walter Scott eens toevoegde, volgens het verhaal van Walpole. De Koningin noodigde Scott uit naar eene aparte kamer te gaan, een conservatory. Scott aarzelde, waarop Caroline hem toevoegde: „Ah, false and faint-hearted troubadour! you will not trust yourself with me for fear of your neck" (Walpole I 249-250).

(b) Walpole I 602. - Dl. IV der Speeches, het slot van Canning's redevoering van den $7^{\mathrm{n}}$ Juni teruggevende, leest men er (bl. 254): Having now discharged that duty to the best of his ability, he hoped he might, without any dereliction of it, indulge his private feelings, bij abstaining, as much as possible, from taking any part in the future stages of these proceedings."

(c) ${ }_{\text {} H \mathrm{He}}$ had been an early and influential adviser of the princess: he would not join in any of the proceedings of her adversaries, and offered to resign, but was not permitted; so he went abroad." Martineau 374. - „Mr. Canning had long been the unhappy Queen's intimate friend; but in adopting her cause, he must... have adopted here party - the party of discontent, the party of reform - a party against which he had, during the last few years, been fiercely struggling. Here, as far as the public can judge from the information before it, lies the only excuse or explanation of his conduct; for it was hardly sufficient to retire (as he did) from any share in the proceedings against a friend and a woman, in whose innocence he said that he believed, when her honour and life were assailed by the most powerful adversaries, and by charges of the most degrading character. - He refused, 
tember, ook October waren dagen van dien strijd en het was toch in October, dat de onderhandelingen over onze koloniale aangelegenheden hervat moesten worden. Daarom droeg Canning uit het buitenland aan den secretaris van den Board of Control op, om Fagel te doen weten, dat de minister vooralsnog niet terugkwam, hetgeen echter ook niet schaadde, daar de inlichtingen uit Bengalen toch nog niet ontvangen waren $(a)$ !

Intusschen had Elout kennis genomen van het antwoord dd. 22 April 1820 door den landvoogd van Bengalen aan onzen GouverneurGeneraal gezonden, op diens afdoend betoog dd. 16 December 1819 over ons recht op Singapore; lord Moira makte zich van de zaak af door te verwijzen naar de onderhandelingen te Londen: "Being in expectation of receiving at an early period the orders of our Government in Europe, announcing the conclusion of an agreement between our respective Sovereigns on all points on which any difference of opinion exists between your Excellency and this Government (b). - Las hieruit Elout, dat de Britsche landvoogd geene

it is true, to be her active accuser; but neither was he her active defender. He remained silent at home or stayed abroad during the time of the prosecution." Characters 311.

(a) Fagel's rapport dd. 20 October 1820 N. 196 (B. Z.): „Mr. Courtenay, secrétaire de l'India Board vint mardi passé me faire les compliments de Mr. Canning, président de ce Board, et me dire de la part de ce Ministre (qui est maintenant à Paris) qu'on n'avait encore reçu aucunes nouvelles de Calcutta sur l'affaire de Singapore, en sorte qu'il n'y avait jusqu'à présent point de temps de perdu relativement à la reprise de nos conférences interrompues par suite du manque de rapport officiel sur cette affaire. Ayant demandé à Mr. Courtenay vers quelle époque il croyait que Mr. Canning pourrait-être ici, il me répondit (comme je le pressentais) que suivant toute apparence son absence se prolongerait encore de quelques semaines, attendu qu'il était convenu (comme je le savais), que Mr. Canning ne prendrait point de part aux discussions parlementaires sur l'affaire de la Reinc. Je doute que Son Excellence revienne ici tant que cette affaire ne sera pas terminée d'une façon ou d'une autre."

(b) Deze officieele correspondentie in Singapore I 425 en 427 ; ov. 37 en 39. - Smulders schrijft spatieerend op bl. 43-44, dat men in Nederland geërgerd was nover de onbetamelijke houding van lord Hastings den Gouv. Gen. van Britsch-Indië, die eene latere nota van van der Capellen in 1820 betreffende Singapore, onbeantwoord had gelaten." - Bedoeld zal wel zijn het onvoldoend beantwoorden van Van der Capellen's betoog dd. 16 December 1819; maar onbeantwoord is het niet gebleven en onbetamelijk heeft men het niet gevonden, daar, gelijk uit het vervolg blijkt, beide partijen nu uitkomst verwachtten van de Londensche onderhandelingen. - Sinds heeft Van der Capellen niet eerder over Singapore naar Bengalen geschreven dan in 1823; zie Singapore II bijl. 9 . 
inlichtingen naar Londen over Van der Capellen's brief zou zenden, hij werd in dit vermoeden versterkt door lord Moira's particulier schrijven dd. 14 Januari 1820 aan Van der Capellen over de Singapore-quaestie, en door diens antwoord dd. 16 April, waarin onze landvoogd mede berustend schrijft: "En attendant, il paraît que, nous trouvant à la veille d'apprendre les nouveaux arrangements conclus par les gouvernements en Europe il sera peut-être bon d'attendre cette époque" (a). En attendant-attendre achtte Elout, die van Van der Capellen afschriften dezer briefwisseling had ontvangen, nu althans niet meer voor de onderhandelingen noodig, gelijk hij dd. 3 November 1820 aan Fagel schreef. Raffles, zoowel als zijne agenten hielden niet op, oordeelde de oud-Commissaris-Generaal, ons bestuur te bemoeilijken, terwijl zich de zaken op Singapore meer en meer zett'en; de spoedige hervatting van de samenkomsten werd daarom zijns inziens van het meest dringend belang. - Fagel sprak er wel een en andermaal Castlereagh over, maar nu diens collega afwezig bleef, kon voorloopig van deze besprekingen geene vrucht verwacht worden. Den $6^{\text {n }}$ November kwam het tot eene laatste stemming over de Koninginne-quaestie, waarbij lord Liverpool's ontwerp werd aangenomen; de Regeering zag echter in de geringe meerderheid der stemmen eene aanwijzing om de zaak niet verder door te zetten, hetgeen door het gansche land met gejubel werd vernomen en Canning vóór de laatste week dier maand naar Londen deed terugkeeren.

Dit gaf Fagel anleiding om Castlereagh opnieuw te bezoeken en over de particuliere briefwisseling tusschen Moira en Van der Capellen te spreken, daar immers voldoende bleek, dat uit Bengalen geene inlichtingen meer konden verwacht worden. De Britsche minister verzocht inzage van die briefwisseling, ten einde ook Canning tot het hervatten der onderhandelingen te bewegen.

Onder dagteekening van 24. November schreef onze ambassadeur er over, zoowel aan Elout als aan Van Nagell; aan dezen minister tegelijkertijd te kennen gevende, dat ten zeerste de heropening der onderhandelingen gewenscht was; ook drong Fagel bij Elout op toezending der particuliere briefwisseling aan, niet twijfelende, dat overlegging ervan een gunstigen invloed op de spoedige hervatting van de onderhandelingen zou uitoefenen (b).

(a) Zie nader over deze particuliere briefwisseling, Singapore I 426-428; ov. $38-40$.

(b) De brief aan Elout in Bijdr. E. 156. Aan van Nagell luidde het schrijven (B. Z.) : „Je suis si pénétré de l'avantage qu'il y aurait à terminer 
Een paar dagen nadat deze betrekkelijk hoopvolle brieven waren afgegeven, namelijk den $27^{\mathrm{n}}$ November, ontmoette onze ambassadeur den heer Canning op een maaltijd bij den Franschen gezant, den heer Decazes (a). Hij maakte van die gelegenheid gebruik om het onderwerp, dat hem zoo na aan het hart lag, ter sprake te brengen; doch onze president van den Board of Control weigerde beslist, vóór de ontvangst der inlichtingen uit Calcutta de werkzaamheden te doen aanvangen. De inlichtingen zouden niet lang uitblijven, meende Canning, daar het hem bekend was, dat lord Moira de Bataviasche depêche van 16 December 1819 had ontvangen; voor inzage van de particuliere briefwisseling bleef hij zich nochtans aanbevolen houden. Fagel zond dit teleurstellend bericht den $28^{\text {n }}$ November aan Elout, zoomede afschrift er van aan minister Van Nagell (b).

Onderwijl had Elout, op het ontvangen van het eerste schrijven,

sans délai ultérieur notre négociation sur l'affaire des Indes Orientales et à profiter pour cela des deux mois de loisir comparatif que la suspension des séances du Parlement va donner aux Ministres que j'ai de nouveau entretenu lord Castlereagh à ce sujet hier. Vous verrez par la copie ci-jointe de la lettre que j'écris aujourd'hui à $\mathrm{Mr}$. Elout, le résultat de cette conversation. Pour gagner du temps j'ai cru devoir écrire à Mr. Elout en droiture, mais je n'ai pu vous laisser ignorer ce que je lui mande."

(a) Decazes was minister van Lodewijk XVIII geweest. De moord van den hertog van Berry dwong Decazes tot aftreden, zeer tegen 's Konings verlangen, in Februari 1820 ; den $26^{\mathrm{n}}$ vertrok hij voor den gezantschapspost te Londen. Revue des Deux Mondes, 15 Juli 1898, bl. 395: "Louis XVIII et le duc Decazes" van Ernest Daudet. Deze hoogst belangrijke artikelen over het koningschap der restauratie zijn ook afzonderlijk uitgegeven.

(b) De brief aan Elout, in Bijdr. E. 157, doch met de foutieve dagteekening van 25 November. - De brief, waarbij de ambassadeur het afschrift aan Van Nagell zond, luidt aldus (B. Z.):

„Mon cher Monsieur,

"J'ai encore l'honneur de vous transmettre la copie ci-jointe de la lettre que j'adresse aujourd'hui en droiture à $\mathrm{M}$. Elout à la suite d'une conversation que j'ai eue hier avec Mr. Canning que je rencontrai à diner chez le duc Decazes. J'ai trouvé Mr. Canning fort abattu de la situation des choses dans ce pays-ci. Il me dit que de toutes les issues possibles du procès de la Reine celle qui avait eu lieu était à son avis la plus fâcheuse, et je ne vous cacherai pas que l'état des affaires devient de plus en plus critique. Tous les papiers publics disent que le Roi a fait appeler samedi passé lord Grenville. Je ne sais si cela est vrai, mais je crains qu'au point où les choses en sont venues ce Lord serait aussi peu en état qu'un autre d'indiquer un remède au mal. Croyez-moi toujours invariablement avec les sentiments que vous me connaissez votre tout devoué serviteur

H, F." 
dus van den $24^{\text {den }}$, zich gehaast bij brief van 29 November 1820 raad aan minister Falck te vragen, die destijds te Brussel vertoefde $(a)$. Hij herhaalde, in de onderhandsche brieven eene duidelijke aanwijzing te vinden, dat beide landvoogden uitsluitend op de beslissing uit Europa wachtten en hij was er uit dien hoofde voor om de beide brieven in hun geheel ter lezing te zenden. "Men zou wel", voegde hij er aan toe, "extractsgewijze de zinsneden daartoe betrekkelijk kunnen mededeelen, maar ik ga verder: ik vind vooral in den brief van V. d. C. zoo veel juiste en krachtige aanmerkingen, dat mijne opinie stellig is, de beide brieven naar Engeland te zenden, en die ter lezing aan de Heeren Castlereagh en Canning te geven, vooral ook omdat Hastings $(b)$ zelve daarin erkent met ronde woorden, dat Raffles ook ten aanzien van Singapore zijne les is te buiten gegaan en daarover gehekeld is, hoezeer men hem nu laat voortgaan, hetgeen V. d. C. dan ook niet onopgemerkt laat. Zijt gij, gelijk ik hoop en vertrouw, met mij van datzelfde begrip, zend dan onder de hand de kopijen aan Fagel ter mededeeling; laat U niet terug houden door de beschuldiging van mijne ungovernable splenetic distaste towards the English (c); het beste is naar mijn oordeel in alles met open kaart te spelen. Het is mij onverschillig welke beschrijving men van mij geven wil; en voor 's Lands belang kan zij, nadat wij reeds conferentiën gehouden en te samen persoonlijk kennis gemaakt hebben, niet meer schaden. Voorts zult gij $\mathrm{U}$ herinneren, dat Canning ons ook confidentieele brieven heeft voorgelezen, en dit zou nu Fagel ook kunnen doen." - Dit schrijven was reeds naar Brussel, toen Fagel's tweede brief over Canning's volstrekte weigering door Elout werd ontvangen. Elout gaf er den $2^{\text {n }}$ December aan Falck kennis van, er op wijzende, dat alzoo eene overlegging der correspondentie het beoogde doel niet zou bereiken. "Maar", vervolgde hij, "eene andere vraag is: moet van deze zijde geheel stil gezwegen worden, of moet er aangedrongen worden op voortgang? en dat wel op grond van den stand der zaken, zooals V. d. Capellen dien onder anderen in den brief mij geschreven en nu nog onder uwe berusting, opgeeft, met aantooning van het verderfelijke daarvan; gelijk mede uit zijnen officieelen aan U over de intrigues bij den Sultan van Sambas

(a) Afgedrukt op bl. 157 Bijdr. E.

(b) De lezer zal zich uit bl. 349 Opvattingen (ov. 9) herinneren, dat lord Moira markies van Hastings was.

(c) Dit stond in lord Moira's brief aan Van der Capellen: zie Singapore I 426-427; ov. 38-39. 
blikt $(a)$. Ln kan ook de brief van Van der Capellen aan Lord Hastings dienen tot overtuiging van de Britsche Ministers, dat zoo lang Raffles net krachtdadiger betengeld wordt, hij steeds zal voortgaan, on tegen de stelligste orders aan, de zaken hoe langer zoo meer nit elkander te brengen, en dat daartegen zeker geen hulpmiddel is, indien de redeneringen van Lord Hastings mogen doorgaan, welke $\mathrm{hj}$ in zijnen onderhandschen brief aan Van der Capellen bij brengt. Kan ook wit dien hoofde de verdere mededeeling van dien brief nuttig zijn? Dit bedoelde ik reeds bij mijnen vorigen, en ik zon er nog zoo over denken: men meet dan de mat vol, en zulk eene handelwijze van onze zjjde kan niet anders dan bij redelijk denkende menschen iets goeds nitwerken. Bestaan er geheime drijfveeren bij de andere zijde, dan is er toch niets aan te doen. Immers het is buiten mijn bereik te beoordeelen, tot hoe verre het al of net geraden is sterk aan te dringen. Ik zie alleen en kan alleen het belang van Indië zien; alle andere consideratien laat ik daar." (b)

Ongesteldheid verhinderde Falck per omgaande te antwoorden. Elout berichtte dit den $5^{\mathrm{n}}$ December 1820 aan Fagel $(c)$, onder mededeeling, dat hij Falck's advies had gevraagd, daarbij zijne teleurstelling uitdrukkende, dat hij en zijn mede-onderhandelaar tot dupen schenen gemaakt te zijn, door het uitstel der onderhandelingen aan te nemen, zonder er bepaaldelijk een fatale termijn gesteld was. "Toen", herinnerde hij in diepe ontstemming over Canning's zucht tot uitstel, "Lord Castlereagh verlangde te kennen den inhoud der brieven, op welker grond ik meende dat er geene nadere berigten uit Indie te verwachten waren, dacht ik, dat zulks ter overtuiging van den Heer Canning (hetgeen men verlangde) strekken moest. Nu de Heer Canning daarna aan Uwe Excellentie verklaard heeft, dat hij wel degelijk nadere berigten wacht, zoo moet ik mijne onderstelling tegen de zijne opgeven, en het is dus niet noodig dit punt nader op te helderen: te minder, daar de Heer Canning bij herhalirig aan Uwe Excellentie verklaard heeft, dat hij niet in de mogelijkheid is de onderhandelingen te hervatten, zoo lang het door hem verwacht wordende berigt niet is aangekomen. Dan toch is er niets te doen dan met geduld te wachten. Of evenwel zulks (als ik mij zoo mag uitdrukken) er door kan, laat ik aan het eigen gevoel van den Heer

(a) De hierover tusschen Batavia en Calcutta gevoerde correspondentie in Singapore II 353 ; ov. 41 .

(b) Bïdr. E. 158-159.

(c) Bijdr. E. 159-161.

$7^{\circ}$ Volgr. II. 
Canning over. Wanneer ik de brieven van Van der Capellen, di ik nu aan den Minister Falck gezonden heb, terug ontvang, za ik U. E. doen zien, hoe verderfelijk de staat der zaken voor d Nederlandsche regten en belangen is, hoe bij voortduring de Hee Raffles en zijne agenten op alle plaatsen van den Indischen Archipel zelfs op Java, intrigeren. Hoe dan ook de openlijke afkeuring zijı moge, die de Britsche Gouverneur-Generaal in Rade en het Europeesch Britsch Cabinet wegens de daden van Raffles aan den dag leggen - hij gaat voort. En als ik de waarheid hulde moet doen, hi wordt met woorden afgekeurd, maar niet éene daad wordt er gedaar om hem in de onmogelijkheid te stellen van voort te gaan. Dar hierover zal ik daarna in meer bijzonderheden kunnen treden, er ik hoop dan dat een en ander op het gemoed van den Heer Canning werken zal. Intusschen zie ik weder eene nieuwe bijeenkomst van het Parlement aangekondigd; zal nu de Heer Canning zich onttrekken kunnen aan de deliberatiën, die de netelige zaak der Koningin toch wel zal aan de hand geven? En hoe lang zullen wij nog moeten wachten, terwijl (a), zooals de Gouverneur-Generaal Van der Capellen wel aanmerkt, Engeland nu in de beata possessio is (b), en deszelfs agenten kwaad op kwaad berokkenen! U.E. zal wel gelegenheid hebben bij voorraad het nadeelige van dat alles daar, waar het pas geeft, te doen opmerken."

Eerst bij brief van 17 of van 19 December $(c)$ was Falck in de gelegenheid te antwoorden. Noch hij, noch zijn ambtgenoot Van Nagell had in beginsel tegen de mededeeling der correspondentie; alleen vestigde hij er de aandacht op, dat boven de brieven stond privaat en vertrouwelijk, zoodat Van der Capellen kon gecompromitteerd worden; vooral had bedenking de passage, waarin lord Moira aan Van der Capellen, een vreemdeling, mededeelde, dat Raffles door de Calcuttasche regeering was weggezonden, doch bij de Compagnie zijne baan had weten schoon te vegen, zoodat men hem met een post van vertrouwen had doen teruggaan. Door het mededeelen van extracten werd het bezwaar niet geheel weggenomen en het effect, dat men van het stuk mocht verwachten, natuurlijk verminderd. Op de hervatting der onderhandelingen kon men ook zonder overlegging dier correspondentie aandringen : "hoewel", meende

(a) Dit woord werd in do drukfoutenlijst der Bïdr. E. toegevoegd.

(b) In $B \ddot{j} d r$. $E$. staat in plaats van is eene komma; blijkbaar eene drukfout.

(c) Opgenomen zoowel in Bijdr. E. 161 als in Falck's Brieven 251; echter met de verschillende dagteekening van 17 en 19 December. Verg. bl. 9 hiervóór. 
Falck - en de uitkomst heeft het juiste van zijn inzicht bewezen - "hoewel ik, zal ik regt uit mijn hart spreken, niet bevroede, hoe de Engelschen voor dien aandrang wijken kunnen, na zoo stellig, zoo herhaaldelijk en niet zonder schijn van reden, verklaard te hebben, dat zij allereerst in het bezit moesten zijn van het berigt van lord H.". - Doch Elout gaf, blijkens zijn antwoord dd. 20 December $1820(a)$, het denkbeeld niet op. Het privaat en confidentieel had geen bezwaar, daar toch Canning aan hem, Elout, en aan Fagel ook in vertrouwen een schrijven van Moira had medegedeeld, waarin hetzelfde over Raffles voorkwam. Nu kon ook Fagel de correspondentie vertrouwelijk en in het minst niet officieel voorlezen, zonder haar af te geven, en zoo, dacht Elout, was dan alles in orde. "Immers ik verbeelde mij dit onder verbetering", voegde hij er aan toe.

De booze man was dan toch eigenlijk, naar het nu scheen, Canning; zoo ja, dan verscheen er een lichtpunt. Het einde van het parlementair proces tegen de Koningin bleek namelijk niet het einde van het schandaal. Er kwamen verscheidene nieuwe quaestiën op, o. a. over het inkomen der Koningin, haar al of niet deelnemen aan de kroning des Konings, die nog plaats moest vinden, enz. Deze omstandigheden deden Canning duidelijk inzien, dat het onmogelijk was langer lid der regeering te blijven; in December 1820 hield hij op president van den Board of Control te zijn. De afspraak onder de ministers was, dat de zaak voorloopig geheim zou worden gehouden, doch het lekte uit, de Courier makte er melding van, en zoo zag hij zich verplicht eene verklaring van zijne houding aan de kiezers te geven, een en ander tot groote ergernis van den Koning (b).

Het bestuur der Oost-Indische Compagnie betreurde dit heengaan ten zeerste. Men keurde een staat van zaken af, ingevolge waarvan zulk een man, die, dank vijfjarige leiding, groote kennis van het Indisch bestuur had gekregen, zijn ontslag moest nemen, omdat hij wegens eene geheel er buiten staande quaestie in gevoelen met de andere ministers verschilde; men achtte het "one of the greatest blots in the system, that the president of the board must retire if a change in the ministry took place, or if a dissimilarity of

(a) Op bl. 163-bl. 165 Bijdr. E. Het et op bl. 163 r. 4 v. o. werd in de drukfoutenlijst verbeterd.

(b) „By this step he was supposed to have incurred the royal displeasure": Martineau 374. 
opinion were manifested" $(a)$. Eene warme dankbetuiging dd. 22 December 1820 ging van den Court of Directors uit, waarin men hem hulde bracht aan zijne eerlijkheid, oprechtheid en hoffelijkheid (b).

Aldus verdween de man van het tooneel, die immers, naar men uit de mededeeling van Castlereagh mocht opmaken, eigenlijk de hervatting van de onderhandelingen tegenhield. De Britsche minister kon zich dus ten deze van alle belemmering ontslagen achten. De lezer zou zich echter wel zéér vergissen, indien hij een oogenblik meende, dat dit aan het status quo een einde makte: Fagel en Elout beiden zagen zich eenvoudig bedrogen.

Met Canning's heengaan was lord Liverpool's kabinet zeer verzwakt. "As to the ministers", zeide dd. 23 Januari 1821 een der parlementsleden in het Lagerhuis $(c)$, "they had fully proved their inability to govern. Never was the community so universally impressed with the conviction of the incapacity of their responsible rulers as at the present moment; so general was that feeling that all ranks of men looked to their removal as their only hope." Uit dien hoofde werd een lid der aan het ministerie weliswaar niet vijandige, doch ook niet zeer bevriende partij, die der Grenville's, waarvan lord Buckingham de leider was, in Canning's plaats als president van den Board of Control verkozen, nadat ze maanden lang onvervuld was gelaten, te weten de neef van den lord, Charles Watkin Williams Wynn, een man, die echter in Canning's schaduw niet kon staan, zooals toenemend zou blijken.

IX.

\section{Vergeefsche pogingen onzerzijds in 1821 tot medio 1822 aangewend om minister Castlereagh tot hervatting der onderhandelíngen te brengen.}

Zoo ging men het jaar 1821 in. De gemoederen werden in Engeland niet meer bewogen door Caroline van Brunswijk, wier onbezonnen poging om bij 's Konings kroning ook tegenwoordig te zijn, aller sympathie weder had doen verliezen $(d)$; maar onderwijl

(a) Woorden van den heer Hume in de vergadering van het East India House op 21 Maart 1821. Bl. 420 Asiatic Journal. Vol. XI.

(b) Zie bijl. 9 .

(c) De woorden bij Walpole, zoowel in I 604, als in II 38 , doch de naam van den spreker is er verschillend gedrukt.

(d) Zij stierf den $7^{\mathrm{n}}$ Augustus 1821 . 
was er een nieuw onderwerp van strijd ontstaan, door de Koninginnequaestie tot dusver op den achtergrond geschoven, namelijk tegen Engelands anti-katholieke wetgeving, ingevolge waarvan o. a. geen katholiek, lid van het Parlement kon worden. De ziel van de beweging daartegen was het Iersche parlementslid William Plunket. Eene den $28^{\mathrm{n}}$ Februari aan het Lagerhuis voorgestelde motie er over werd den $2^{\mathrm{n}}$ April aangenomen, doch hare verwerping in het Hoogerhuis den $18^{\mathrm{n}}$ d. a. v. makte ook aan dien strijd, althans voorloopig, een einde $(a)$.

Had onze Londensche vertegenwoordiger zich verplicht gezien, minister Castlereagh in die moeilijke dagen niet lastig te vallen met de koloniale quaestie, medio Maart scheen deze voldoende rust te hebben, om hem er andermaal over te gaan spreken. Fagel kreeg nu echter evenzeer van hem een onwelwillend antwoord en wel tengevolge van eene zaak, die middellijk mede met ons koloniaal beheer, speciaal van onze West-Indische koloniën, verband hield.

Op het einde der $18^{\mathrm{e}}$ eeuw deed zekere Ramsay als geneesheer dienst bij de Engelsche marine en was daardoor getuige geweest van wreedheden in den slavenhandel. Hij schreef er in 1783 of 1784 een boek over, dat wel indruk makte, doch vermoedelijk geene practische gevolgen zou gehad hebben zonder de tusschenkomst van de familie Middleton. Hij kwam er aan huis, doordien Charles Middleton commandant van het oorlogsschip was geweest, waarop Ramsay dienst had gedaan. De raad dier familie, om de aangelegenheid voor het Parlement te brengen, meende hij wel niet te kunnen opvolgen, daar hij geen redenaar was; maar tevens werd zijne aandacht gevestigd op een jongen, aanlegvollen man, den in 1759 geboren William Wilberforce, die omstreeks 1784 lid van het Parlement werd. Ramsay's beroep op deze was niet te vergeefs. Wilberforce aanvaardde den strijd voor de afschaffing van den slavenhandel met groote warmte en zag zijn streven in 1807 bekroond met de wet, die aan den Britschen slavenhandel een einde makte. In de volgende tien jaren beijverde hij zich de zaak internationaal te maken; ook in die breede werkzaamheid had hij een schitterend succes. (b)

Doch aan aanmatiging van Engelands zijde ontbrak het ook hier

(a) Walpole II 198-203.

(b) Een aantrekkelijk beknopt overzicht van Engelands binnen- en buitenlandsche politiek in zake slavernij-bestrijding vindt men o. a. op bl. 12 vv. dl II (1899) van Dr. Alfred Zimmermann's werk: "Die Kolonial Politik Groszbritanniens". 
niet. Het goede kan onverdragelijk worden, wanneer vreemde politie het aan de menschen wil opdringen. Overdrijving, aanstellerij, doordrijverij, ellendige zucht om, met Chamberlain's woorden in Transvaal-aangelegenheden, ploegen in eens andermans land te zetten, gehuichel ten einde de slavernij als een dekmantel voor koloniale aanwinsten te doen strekken: dit alles bleef natuurlijk nu evenmin als vroeger en later uit. De staatkunde bemoeide er zich mede; vooral de kleine landen zouden het ontgelden; wat niet wilde buigen, dat moest maar barsten.

In Europa hadden Frankrijk, Denemarken, Zweden, Nederland zich krachtig genoeg getoond met hunne betuigingen tegen den slavenhandel. Wat ons betreft, wij waren ter nauwernood uit den strijd van 1813 een weinig tot adem gekomen, of men had ons al het thema onder de aandacht gebracht. Koning Willem I scheen het prachtig te vinden. Art. 8 onzer koloniale conventie van 13 Augustus 1814 verklaarde althans, dat: - "animé d'un vif désir de coöpérer de la manière la plus efficace avec Sa Majesté le Roi du Royaume Uni de la Grande Bretagne et d'Irlande, à l'effet de parvenir à l'entière abolition de la traite des esclaves sur la côte de l'Afrique" - onze Souvereine Vorst aan al zijne onderdanen verbood "de la manière la plus efficace et par les lois les plus formelles, de prendre aucune part quelconque à ce trafic inhumain" $(a)$.

Het moet gezegd worden, uit zich zelf toonden de leidende Britsche staatslieden niet bijzonder veel lust om zich verder met de vreemde mogendheden in deze zaak te bemoeien $(b)$; doch aan den anderen

(a) Sluiting 273 ; ov. 35 .

(b) Eene karakteristieke bijdrage daarover leest men in de Brieven-Hogendorp VI, 301, waar Van Hogendorp dd. 23 April 1816 het volgende opteekent over een gesprek, dat hij ten aanzien van den slavenhandel had met den hertog van Wellington eenige dagen te voren op een diner bij den Souvereinen Vorst: "Quel fut mon étonnement, quand je lui entendis dire, et répéter avec satisfaction, qu'au Congrès de Vienne Lord Castlereagh et lui avaient jusqu'au dernier moment voté contre l'abolition.

„A vant qu'on se mit à table, le Général Alava (Spaansch minister en vroeger adjudant van den hertog van Wellington) avait fait beaucoup de bruit dans le même sens. Il s'était notamment plaint de l'Autriche, qui, dit-il, n'ayant pas un seul noir, avait décidé l'abolition en se déclarant.

„Il en résulte que la Russie et la Prusse ont poussé l'affaire, que l'Autriche a fini par se joindre à ces deux Puissances, que les ambassadeurs anglais alors n'ont pû tergiverser, que la France, l'Espagne et le Portugal n'ont pû s'empêcher d'y adhérer sous les restrictions connues.

${ }_{n}$ C'est done en dernier résultat l'Empereur Alexandre, qui est le véritable auteur de l'abolition, fortifié par l'opinion prononcée du peuple anglais. 
kant dient men ook in het oog te houden, dat een Engelsch ministerie zich gaarne een weinig laat drijven; de regeering pleegt dan daarop een beroep te doen, zoo noodig met 'n verontschuldigend: "Als het van mij alleen afhing, zou ik wel anders willen."

Hier waren het Wilberforce en door hem de publieke opinie, zich uitende in het Parlement en in de dagbladen, die den almachtigen minister Castlereagh den internationalen weg verder opdrongen $(a)$. Zoo kwam de zaak op het Weener congres, waar Castlereagh en Wellington zich schaarden .... onder de bestrijders! Maar onder de mogendheden, die verklaarden wel te willen medegaan, behoorde Spanje, betuigende evenwel de fondsen te missen, om er iets aan te kunnen doen. Engeland gaf dientengevolge in 1818 aan deze mogendheid 400.000 pond sterling, niettegenstaande een groot deel der Britsche bevolking zelve destijds van armoede verging (b)!

Hetzelfde jaar 1818 werden ook Nederland de duimschroeven wat aangezet. Een tractaat van 4 Mei $1818(c)$ - hetwelk nota bene eerst bij besluit van 14 November 1848 in het Staatsblad der Nederlanden verscheen $(d)$ - regelde de wijze van uitvoering van het hiervoren vermeld art. 8 der Londensche conventie van 1814 . Onze gevolmachtigden waren de ministers van Buitenlandsche Zaken en van Justitie, de heeren Van Nagell en Van Maanen. In tien artikelen werden de uitvoerende bepalingen omschreven, alweder:

„Mais quelle a été la conduite des ambassadeurs de l'Angleterre? Nous voyons tous les jours Lord Castlereagh se vanter dans le Parlement de ses prouesses en faveur de l'abolition. Cependant au Congrès il a voté contre la mesure jusqu'au dernier moment. Il avait donc des instructions secrètes, contraires aux instructions avouées et publiques. Le due de Wellington annonce tout haut, qu'il a travaillé jusqu'au dernier moment contre ses instructions publiques. Que devient sa loyauté?

„J'ai été frappé, mais surtout en ce moment, de sa tournure irlandaise." (a) "Il existe en Angleterre un parti considérable dirigé par la secte des Méthodistes, et auquel se rattachent les Wilberforce et quelques membres du parlement, qui font profession d'une certaine indépendance politique, et qui n'appuient le ministère que sous des conditions dont l'une est l'abolition de la traite des nègres. Ce parti, qui poursuit son plan avec une sorte de fanatisme, est lié comme toutes les sectes religieuses qui ne sont pas dominantes, par les noeuds les plus forts; il agit avec un ensemble qui en impose singulièrement au gouvernement, toujours empressé de le caresser et de suivre sa direction, toutes les fois qu'elle n'est pas diamétralement contraire à ses vues." Richelieu 103.

(b) $\mathrm{Bl} .470 \mathrm{dl}$. I Walpole.

(c) Zie o. a. Hertslet's "Complete collections of the treaties..." dl. I (1827) bl. 380-391.

(d) Zie 1848 N. 79. 
"animées d'un désir mutuel d'adopter les mesures les plus efficaces pour empêcher le commerce des esclaves par leurs sujets, et prevenir que d'autres nations qui s'y trouvent engagées ne se servent de leurs pavillons respectifs pour protéger cet odieux trafic". Slavenschepen van Nederlandsche of Engelsche herkomst konden door de oorlogsmarine van beide mogendheden worden onderzocht en goeden prijs verklaard; gemengde rechtbanken zouden over de gevallen oordeelen; enz.

Op papier was dat alles heel mooi. Toen wij nog onze koloniën moesten terugkrijgen, had reeds de Souvereine Vorst bij een besluit van 15 Juni 1814 zich gehaast een verbod tegen den slavenhandel uit te vaardigen, ten einde Engeland pleizier te doen, ofschoon het heette genomen te zijn uit eigen beweging. Eenmaal echter in het bezit der West-Indische koloniën, ging spoedig het pleizier tot handhaving van het verbod er af; wij vonden namelijk dat Nederlandsch West-Indië met den slaventoestand stond of viel.... De conventie van 1818 was een moetje en minister Van Nagell, die zoo zeer aan het bezit dier koloniën had gehangen en zeer aan den slavenhandel gehecht was $(a)$, zal er wel met een zuur gezicht toe mede gewerkt hebben.

Zoo de minister; zoo feitelijk de openbare meening in Nederland. Volk en regeering beiden dreven naar kunstmatige opwekking van den handel en wat daarmede verband hield. Eene breed opgevatte slavernij-hervorming was er geenszins populair. "De onverschilligheid der Nederlandsche regeering voor hooger dan eigen handelsbelang", waarover het Nederlandsch Anti-Slavernij tijdschrift klaagde (b), zou nog eene lichtzijde gehad hebben, wanneer inderdaad dat handelsbelang bij ons helder genoeg was ingezien; doch men bewoog zich toenemend in eene richting, die allen heil deed zoeken in maatregelen, waarvan het kunstmatige onze geestkracht verder doodde en dat ons telkens op gespannen voet bracht met eene vreemde regeering, wier goede diensten voor ons dikwerf onmisbaar waren.

De zaak kwam dan hierop neder, dat wij niet oprecht of in gemoede tot de bestrijding van den slavenhandel medewerkten. Stelselmatige twintigjarige misleiding was nog in 1843 de beschuldiging, die zich over de schending van het tractaat van 1818 tegen Nederland hooren

(a) Zie bl. 40 hiervóór.

(b) Utrechtsche Bïdragen 383. 
deed (a); eene misleiding, welke in 1821 zelfs zóó tastbaar werd, dat koning Willem I over zijne averechtsche opvatting van het tractaat van 1818 niet slechts in strijd kwam met al zijne ministers, maar ook met den Raad van State $(b)$. De zending eerlang van den heer Van den Bosch, die in de West eene leerschool had doorloopen, naar Oost-Indië om daar het Cultuurstelsel in te voeren, maakt het ons duidelijker, dat de Koning over de anti-slavernij niet bijzonder orthodox dacht. De brandende quaestie werd nu deze : van Nederlandsche zijde werd beweerd, dat de slavenhandel was geoorloofd gebleven, uitgezonderd rechtstreeks met Afrika, terwijl van Engelsche zijde, en op goeden grond, werd volgehouden, dat de conventie van 1818 allen slavenhandel verbood.

De Engelsche regeering gelastte haar gezant Clancarty om met den meesten ernst tegen de schending der aangegane belofte op te komen; en daar wij niet toegaven, ontstond zekere wanverhouding tusschen koning Willem I met zijne ministers en den Britschen vertegenwoordiger, dien wij te voren steeds als een ons welgezind man hoogelijk hadden gewaardeerd.

's Konings raadslieden moesten wel de stijfhoofdigheid, waarmede onze vorst zijn standpunt handhaafde, tegenover den aandringenden gezant eerbiedigen. Van Nagell begon met Clancarty in diens breede uitlegging der slaven-conventie tegen te spreken. De zaak bleek echter zó zwak, dat de minister eindelijk had moeten toegeven op een dd. 23 December 1820 ingezonden "energetic note", gelijk gespatieerd staat in een nader te noemen rapport van den Britschen gezant aan minister Castlereagh dd. 5 Januari d.a.v.

Clancarty was intusschen, op verzoek van Van Nagell, onzen departementschef voor de Koloniën, den heer Falck, gaan spreken en deze, nogal leuk, meende de zaak over een anderen boeg te kunnen werpen. Onze minister begon eenigszins hoog op te merken, dat het slavenverdrag eigenlijk niet zeer klaar was, zoodat men wel zou doen over een nieuw te onderhandelen. Vermoedelijk wilde hij alzoo er toe komen, om daaraan dan tevens de voortzetting der onderhandelingen van 1820 te verbinden, doch Clancarty gaf hiertoe geene gelegenheid, daar hij opmerkte, dat de duidelijkheid niets te

(a) Bl. 19 der Vtrechtsche Büjragen.

(b),$\ldots$. in which all those styled Ministers, including the whole Council of State, are with us, the King alone against us". Rapport van den Engelschen gezant te Brussel Clancarty dd. 3 Augustus 1821 aan minister Castlereagh. Zie Corr. 421. 
wenschen overliet, zoodat een nieuw verdrag niets kon baten $(a)$. Falck gaf daarop in wat lager toon te kennen, dat hij over de quaestie zou nadenken en het resultaat hem ten spoedigste mededeelen. Hij vond het nu echter eene goede gelegenheid, om toch te komen op de reden, die tot het afbreken der onderhandelingen van 1820 had geleid, uitende zijne rechtmatige grieven over het voortdurend uitstellen van het inlossen der belofte om ze weder ten spoedigste op te vatten. Nu liet hij ook Clancarty de particuliere brieven der twee landvoogden zien, waaruit dan toch duidelijk bleek, dat geene nadere inlichtingen uit Bengalen konden verwacht worden; "en ik moet bekennen", rapporteerde de gezant naar Londen, "dat zij ook voor mij (speciaal de brief van lord Hastings) ten volle deze gevolgtrekking rechtvaardigen". Maar op Falck's toeleg om aldus Engeland langs den weg eener wijziging van de slavenconventie tot de door Nederland zoo zeer verlangde herziening van het koloniaal tractaat van 1814 te brengen, ging de gezant niet in, zóó weinig, dat hij bij zijn rapport van 5 Januari 1821 minister Castlereagh aanried, dat men onze wenschen voor de hervatting van de koloniale onderhandelingen moest beantwoorden met de opmerking, dat Engelands genegenheid om alle hangende koloniale quaestiën bij verdrag uit te maken, niet toegenomen was, ten gevolge van de wijze, waarop een bestaand tractaat door de Nederlandsche regeering werd begrepen. Alsof niet het koloniaal verdrag van 1814 op schandelijke wijze door Raffles en zijne handlangers werd geschonden! $(b)$

Wij zagen ons intusschen wel verplicht Engeland eerst genoegen te geven; en uit dien hoofde vaardigde de regeering nadere instructiën uit, die eene meer stipte nakoming van de slaven-conventie moesten beoogen. Het werd den gezant medegedeeld, doch aan diens verzoek om de stukken te mogen lezen, durfden we geen gevolg geven, wijl ze veel te onbeduidend waren!

Vandaar dd. 26 Februari 1821 eene nota van Clancarty, waarin hij gehoor bij onzen Koning verzocht, ten einde mondeling op eene afdoende verklaring omtrent het tractaat van 1818 te staan en zich opnieuw over bepaalde gevallen van schending der conventie te

(a) Nochtans zijn dd. 31 December 1822 en 25 Januari 1823 ophelderende en additioneele artikelen tusschen beide mogendheden vastgesteld, welke door koning Willem I dd. 31 Januari en 19 Februari d. a. v. werden bekrachtigd. Zie het aangehaald Staatsblad 1848 No 79.

(b) Men leze Clancarty's belangrijk rapport in bijl. 10. 
beklagen. Er kwam evenwel geen antwoord; de gezant achtte het intusschen gepast om geduld uit te oefenen, wijl de Koning ongesteld heette te zijn. De Engelsche regeering spoorde echter Clancarty nader aan, wijl zij zich in het Parlement over onze houding had te verdedigen. Den $26^{\mathrm{n}}$ Maart 1821 zond de gezant dientengevolge eene nieuwe nota aan minister Van Nagell. Hij herinnerde er aan, dat de Koning nu hersteld was en verzocht daarom alsnog audientie, "om persoonlijk op te komen voor hetgeen niet enkel de belangen waren van zijn eigen land, maar, welbeschouwd van beide landen" (a). Afschrift van dit stuk zond de Britsche gezant den volgenden dag aan minister Castlereagh, onder mededeeling, dat hij de zaak tot het uiterste zou drijven: "even", schreef hij onderstrepend, "to what may grow to a breach between me personally and this Government which, however must I sincerely hope it will not take place". Hoe zich de gezant dat persoonlijk afbreken wel voorstelde?(b)

Den $17^{\mathrm{n}}$ April 1821 zond hij een nieuw toornig rapport naar Londen met klachten over onze dubbelhartigheid. Het was nu duidelijk, berichtte hij, dat de Koning der Nederlanden de anti-slavenbepalingen wilde ontwijken; dat moest en mocht niet toegelaten worden; daarom beval hij minister Castlereagh aan - in deze maand door erfrecht markies van Londonderry geworden, gelijk hij sinds in de correspondentie heet - onzen Londenschen gezant niets in te willigen, wat deze ook mocht vragen! Hoe vriendelijk Fagel om zijn persoon verdiende bejegend te worden, - als vertegenwoordiger van zoo'n meester, behoorde men, meende Clancarty, hem niet beter te behandelen dan zulk een meester verdiende en tot deze geleerd zou hebben om meer tegemoetkoming waardig te zijn!! (c)

(a) De nota in bijl. 11.

(b) Clancarty's brief in bijl. 12.

(c) Over Fagel's uitnemende verhoudingen te Londen, zie Fagel's Ontslag 402-404; ov. 10-12. Clancarty's karakteristieke brief dd. 17 April 1821 komt voor in de Corr. 391 en luidt aldus:

"I write but a line, merely to solicit your attention to the postscript of my despatch, No 16, of this date, and to its enclosure, where you will see confirmed (what has probably long been suspected by you) that the Netherland Monarch is endeavouring to evade the execution of his treaties with us relative to the Slave-Trade.

"This will not do, and must not be allowed. I have therefore to renew my request to you to do nothing which, on the part of his Government, shall be asked of you by Fagel, and, however kindly, as an individual, you may treat him, I pray you that, as the representative of his master, he may not be better treated than such a master deserves, till the master shall learn to deserve better." 
Weldra zou zich eene gelegenheid voordoen, om Fagel te toonen, dat dit ernstig gemeend werd.

Reeds had deze de terugwerking van het geschil ondervonden, toen hij dd. 17 Maart 1821 een bezoek aan Castlereagh bracht, ten einde beklag te doen over Raffles' weigering tot overgave van Ajer Bangis op Sumatra's Westkust, waartoe onze gezant eene opdracht had gekregen, ingevolge voorstel dd. 28 Februari 1821 aan den Koning (a). Het mag daarbij wel zonderling schijnen, dat onze regeering haar gezant niet tevens volledig op de hoogte stelde van het branden der slavenquaestie; zij kon toch, dunkt me, wel bevroeden, dat Fagel's positie er onder zou lijden. Het persoonlijk bestuur van Willem I belette echter een normalen gang van zaken, zoo tusschen de departementschefs onderling, als tusschen Buitenlandsche Zaken en de Nederlandsche vertegen woordigers in den vreemde.

Castlereagh gaf Fagel te kennen, dat de onderhandelingen over het tractaat van 1814 zouden hervat worden, zoodra de Bengaalsche stukken waren ontvangen, die zeker nu niet lang meer konden uitblijven. Onmiddellijk daarop roerde echter de minister het slavengeschil aan; hij wenschte, dat onze regeering toch spoedigst zou besluiten tot overlegging harer instructiën hierover, ten einde daarmede in het Parlement een goeden indruk te maken.

Denzelfden dag, dus 17 Maart 1821, rapporteerde de gezant het gesprek aan Buitenlandsche Zaken, er bij voegende, dat hij zich tot de enkele mededeeling ervan wel moest bepalen, daar hij immers van de slavenquaestie niets afwist! (b)

Weldra moest Fagel zijn bezoek bij Castlereagh hervatten; en aangezien hij dit deed kort nadat de minister het tweede nog ontstemder schrijven van Clancarty had ontvangen, kreeg onze gezant den wind van voren, althans voor zoover men dat mag zeggen van een man, zoo geheel in de vormen als Castlereagh inderdaad was.

Minister Falck had namelijk in een rapport dd. 30 April 1821 den Koning weder gewezen op de nadeelen van het status quo ten opzichte der Indische quaestiën. Er was tijd genoeg geweest, merkte hij terecht op, om uit Britsch-Indië de inlichtingen te erlangen, die de Engelsche gemachtigden noodig hadden geacht; zelfs om ze uitdrukkelijk op te vragen, zoo men ze van Calcutta niet uit zichzelven had gezonden. Daargelaten de steeds betoonde onvriendelijke

(a) Zie over deze quaestie Sumatra's Westkust II 229 vv; ov. 25 vv. Van Nagell's schrijven aan den Koning op bl. 306; ov. 182.

(b) Zie bijl. 13. 
gezindheid van den luitenant-gouverneur Raffles te Benkoelen, had het onafgedaan blijven der geschillen en de hiermede verbonden staat van onzekerheid een nadeeligen invloed op de behandeling van velerlei zaken, op de gezindheid der vorsten en volksstammen, die meer dan eenige andere, naar hetgeen zij zagen en naar bepaalde daadzaken oordeelden, en, volgens de opinie van den heer Jan der Capellen, ook op de stemming van den sultan van Palembang. "Ons belang dus, om op de hervatting der onderhandelingen aan te dringen", meende de minister "is buiten twijfel. Ons regt daartoe, na eene geduldsuitoefening van zeven of acht maanden, komt mij even zeker voor, en hoewel ik mij omtrent de diplomatieke convenientien niet even stellig vermag te uiten, meen ik echter, dat ook ten dezen, daar wij het tijdperk van het regtsgeding tegen de Koningin Carolina en dat der discussiën over de bill ten gunste der Katholieken hebben laten voorbijgaan, alles in acht genomen is, wat men van den meest welmeenenden bondgenoot konde vorderen of verwachten." $(a)$

Het gevolg was eene opdracht dd. 24 April 1821 van den minister van Buitenlandsche Zaken aan onzen gezant om de Britsche regeering andermaal te interpelleeren (b).

Fagel begaf zich den $1^{\mathrm{n}}$ Mei tot Castlereagh, die, gelijk ik mededeelde, een paar weken te voren, nog eene ernstiger aanmaning van Clancarty had ontvangen, om Fagel per se alles te weigeren! De minister moest dus eene houding aannemen. Gezant Fagel, geheel onbekend hiermede, binnentredende, vond Castlereagh met een papier in de hand. Onder 's ministers gewone opgeruimdheid, voegde Castlereagh den binnentredende lachend te gemoet: "Je ne sais pas ce que vous avez à me dire, mais moi, j'ai à vous gronder." - Fagel had echter ook een papier in de hand, namelijk Van Nagell's depêche; deze evenzeer ophoudende, antwoordde hij gevat op denzelfden lachenden toon: "Je vous en offre autant, Milord! "Qui sera-ci donc de nous deux, qui commencera à gronder l'autre?" Hierop begon Castlereagh zijn papier voor te lezen, dat klachten inhield van Wilberforce over onze schending van de slaven-conventie.

Fagel moest alweder antwoorden, dat hij geheel daar buiten

(a) Opgenomen in Falck's Ambtsbrieven 140 No 15.

(b) „Le Roi m'a ordonné de rappeler à V. E. la longue interruption qui a lieu dans nos négociations relatives aux affaires des Indes Orientales; il paraît qu'il s'est écoulé un temps suffisant pour receuillir toutes les informations nécessaires et S. M. désire qu'Elle en entretienne S. E. le Marquis de Londonderry à la première occasion favorable qui se présentera." (B. Z.) 
stond, dat hij niets van de zaak wist; maar hij beloofde de grieven onder de aandacht zijner regeering te brengen. Als altijd luidde 's ministers bescheid omtrent de hervatting der onderhandelingen, welwillend; doch de gezant besloot niettemin zijn rapport, waarin de hier verhaalde conferentie stond beschreven, met de verzekering, dat aan deze hervatting in geen geval te denken zou vallen, zoolang de Nederlandsche regeering de slavenquaestie niet naar Engelands genoegen had uitgemaakt. (a)

Terwijl dit alles in de officieele wereld voorviel, beijverden zich de Britsche publicisten om voor de handhaving van de Engelsche vlag te Singapore te strijden, de ministers, die het prijsgeven van dezen post durfden voorschrijven, met vervolging dreigende, en den moord van Amboina voor de zooveelste maal ten tooneele voerende (b). Kieschheid in de behandeling eener zaak, waaromtrent het bezitrecht nog niet was uitgemaakt, kende men evenmin in de bureaux der Britsch-Indische administratie $(c)$, als in het Britsche parlement. Singapore's schitterende toekomst breedelijk besprekende, behandelde men het onderwerp, alsof van teruggave nooit quaestie kon zijn.

Onzen gezant Fagel deed dit alles pijnlijk aan, gelijk blijkt uit zijn particulier schrijven dd. 8 Mei 1821, waarin hij Elout geluk wenschte met diens optreden dd. 1 dier maand, als minister van Financiën. "Met opzigt tot onze onderhandelingen", leest men daarin, "blijft alles in statu quo. Men heeft nog geen antwoord van Calcutta. Ondertusschen zie ik met leedwezen in een Rapport, deezer dagen door den Markies Van Landsdown in het Hoogerhuys uitgebragt, namens het Comitté tot onderzoek der vreemde handelsbetrekkingen van dit Rijk (speciaal in Indien), eene passage, waarin met veel ophef gesproken wordt van het nieuwe etablissement van Sinca-Poura en van deszelfs aanwas seedert dat de Engelschen zich in het bezit van hetzelve gesteld hebben." $(d)$

Ook onze vorst gevoelde zich onvoldaan én door Clancarty's aandrang in zake slavernij, én door Engelands houding ten opzichte der Indische zaken. Vooral de energieke nota's van den Britschen gezant hadden hem diep gegriefd, zelfs in die mate, dat op den eigen dag, dat Fagel zijne mismoedigheid aan Elout openbaarde,
(a) Fagel's rapport dd. 2 Mei 1821 in bijl. 14.
(b) Zie Singapore II 331; ov. 19.
(c) Zie hoofdstuk IV van Singapore III.
(d) Bïjdr. E. 165 . 
dus den $8^{\text {n }}$ Mei 1821, de Koning het advies van Buitenlandsche Zaken deed inwinnen over de vraag: "of niet voortaan zoude kunnen en behooren aan de nota's, door den Britschen ambassadeur, wegens hetzelve onderwerp, alhier gepresenteerd, te Londen door den Nederlandschen ambassadeur geantwoord te worden, ten einde daardoor weinige onaangenaamheden voor te komen".

Zóó schreef 's Konings secretaris, de heer Van Gobbelschroy (later, van medio 1825 tot einde 1829 minister van Binnenlandsche Zaken) onze taal, die hij als Zuid-Nederlander niet machtig bleek. Maar het was 's vorsten stellige wensch, dat het Fransch uit de correspondentie zou verdwijnen, eene tot zekere grens eerbiedwekkende opvatting, doch waarbij ook al weder niet de juiste maat werd gehouden. Het doordrijven wekte bij onze zuidelijke landgenooten algemeen weerzin en gaf tot veel spot in de bladen aanleiding :......

Ah! que les vieux mots sont mauvais,

Qu'ils ont un air gothique!

La nouveauté me pique,

Je sens pour le néerlandais!

Quelle magie!

Quelle harmonie! enz. enz. (a).

Niets echter ook scheen den Koning te kunnen bewegen om in de slavenquaestie eenigszins toe te geven. Men stond nu in het midden van 1821 en nog was Clancarty's diplomatie niet in staat gebleken te zegevieren op 's vorsten onwil tot overlegging der instructiën. De gezant bleef er intusschen op staan en raadde in een nieuw karakteristiek schrijven van 3 Augustus 1821 zijne regeering aan, om toch van den eisch niet af te zien, al ware het slechts ter voorkoming, dat onze vorst telkens op nieuw twist met het Engelsch bestuur zou zoeken, hetgeen men zeker kon verwachten, als men hem zijn zin gaf! (b) Ten einde den vorm te redden, verzocht Clancarty eene bepaalde opdracht uit Londen, dat hij de instructiën zou vorderen en men kon er dan uit beleefdheid aan toevoegen, dat de Britsche stukken tegen slavenhandel ook steeds ter beschikking van de Nederlandsche regeering zouden zijn. Eene dergelijke wederkeerigheid werd meer dan eens in acht genomen om onze onderworpenheid aan tegen Nederland gestelde eischen te verbloemen $(c)$.

Intusschen had men in Engeland zelf een ander middel bedacht
(a) Kemper 542 .
(b) De brief in bijl. 15 .
(c) Zie ook hl. 65 . 
om den Koning tot toegeven te bewegen. De hertog van Wellington moest naar het vaste land vertrekken, ten einde de barrière-vestingen in oogenschouw te nemen; Castlereagh verzocht hem van die gelegenheid gebruik te maken om onzen Koning, dien de hertog toch ontmoeten zou, over het slavengeschil te spreken. Deze had er echter niet veel lust in, en weigerde volstrekt om er over te beginnen; doch toen eene week na Clancarty's schrijven, Wellington te Brussel een onderhoud met Willem I had, werd de gewenschte gedachtenwisseling zeer gemakkelijk uitgelokt doordien de Koning uit eigen beweging haar opende. Vervuld toch van het wederrechtelijke, dat Nederland in zoovele opzichten van Engeland ondervond, stortte hij zijn gemoed tegenover de hem bezoekende Wellington en Clancarty in ronde woorden uit. Het geschiedde met een vorstelijk zelfbewustzijn, dat beiden, den Britschen veldheer en den Britschen diplomaat, ten zeerste trof. "I did not perceive", memoreerde de een dd. 12 Augustus 1821 over den aanvang van het onderhoud, "any coldness in his reception of me or in manner or conversation" $(a)$. "The King", schreef de ander den $14^{\mathrm{n}}$ d.a.v., "having, after dinner the same day, taken me aside, and, for near half an hour, assured me of his anxious desire to be always on the most confidential footing with my Government, and personnally complimenting me upon my conduct from the first hour at which I was presented to him in London up to the present moment, in terms which it would ill become me to repeat" (b). Toch was dit samengegaan met de breede blootlegging van 's Konings grieven. Hij had zijn leed betuigd van met het Britsche gouvernement op niet zoo'n goeden voet als vroeger te staan; dat hij op onaangename wijze over de slavenquaestie werd lastig gevallen; dat de onderhandelingen over Oost-Indië waren gestaakt, terwijl de Britsche regeering ongenegen scheen ze te hervatten.

Wellington verschool zich natuurlijk achter het niet-weten, waar 's Konings ergernis volkomen gerechtvaardigd mocht heeten; de hertog trachtte niettemin een verschoonend woord hiervoor bij te brengen en wel door als vermoeden te opperen, dat het aftreden van den president van het Londensch koloniaal bestuur, den heer Canning, en de daarmede samenhangende vervanging van den heer Wynn, stoornis hadden teweeg gebracht; doch hij toonde bovendien wel zóóveel van de zaak te weten, dat hij er evenzeer op kon aan-

(a) Wellington's brief in Corr. 425-429.

(b) Clancarty's brief in Corr. 422-425. 
dringen om de slavenquaestie niet aan die der afgebroken onderhandelingen te koppelen. De Britsche regeering, herhaalde Wellington, zou door overlegging van de Nederlandsche instructiën, in staat gesteld worden aan gansch Engeland te bewijzen, dat de Koning alles binnen zijn vermogen had gedaan voor de handhaving der conventie van 1818.

Doch toen dit onderwerp aldus uitvoerig door Wellington was besproken, kwam de Koning opnieuw, en niet onnatuurlijk, terug op het punt, dat hem bij uitstek ter harte ging. Hij bracht in herinnering de correspondentie, die de landvoogden te Calcutta en te Batavia hadden gewisseld en waaruit ten duidelijkste bleek, dat er op nadere berichten uit Bengalen niet te wachten viel, terwijl men dit nochtans te Londen als eene reden voor het niet hervatten van de onderhandelingen aanvoerde. Zoo werd feitelijk door den Koning de waarheid gezegd, namelijk dat men ons bedroog; maar Wellington sloot zich nu weder op in zijne volstrekte onbekendheid met deze aangelegenheid. "I repeated", berichtte de hertog in zijn memorandum naar Londen, "that I was quite ignorant of the question; that I neither knew how it stood, nor on what it had turned, but that it appeared to me there was nothing inconsistent in what had passed; as it was very probable that information was required from Lord Hastings, which he might be the only person capable of giving, at the same time that he should have broken off all discussion upon the subject with the Governor-General of Batavia."

Hiermede eindigde een onderhoud, dat vol voetangels en klemmen had toegeschenen, tot beider voldoening. "I took my leave", besloot althans het memorandum, "having left the King, as I thought, better satisfied and pleased than he had been."

Maar zoo de hertog had vermeend, dat hiermede ook het punt in quaestie kon gewonnen heeten, dan zou hij buiten het karakter van onzen vorst hebben gerekend. De zaak was nog onafgedaan, toen de koning van Engeland, Wellington en Castlereagh in September 1821 Brussel bezochten (a). De Koning had minister Van Nagell last gegeven, om van die gelegenheid gebruik te maken, de koloniale onderhandelingen andermaal op het tapijt te brengen;

(a) „Le 27 Septembre (1821), George IV arriva à Bruxelles et le lendemain il $\mathrm{y}$ eut grand banquet au chateau de Laeken; auprès des deux rois intimement alliés, se trouvaient les lords Wellington, Castlereagh et Clancarty": Juste 47. 
doch het daarop gevolgd bezoek had weder geen ander gevolg, dan dat nu ook Castlereagh antwoordde, dat men nog maar altijd op de Bengaalsche stukken wachtte.

Eindelijk, namelijk in den aanvang 1822, slaagde Clancarty er in, de slaven-instructiën toegezonden te krijgen. Wat echter de Britsche gezant daarover dd. 18 Januari 1822 naar Londen rapporteerde, was wel weder zéér kenschetsend. Met de koppigheid Zijner Majesteit eigen, "with that sub-acid humour by which his Majesty is sometimes governed", werden hem geene officieele Engelsche vertalingen van de instructiën verstrekt, immers enkel Nederlandsche afschriften. De gezant had ze in het Engelsch doen overzetten en van Falck de verzekering ontvangen, dat aan de vertaling niets ontbrak $(a)$.

$\mathrm{Nu}$ bleken bovendien deze instructiën zóó weinig afdoende, zoó treurig, dat ze wel bij openbaarmaking tot de meest kwetsende critiek aanleiding moesten geven. Uit dien hoofde had onze minister van Koloniën ernstig bezwaar, dat ze aan het Parlement werden overgelegd, terwijl het toch juist daarom te doen was. Falck stelde Clancarty een middenweg voor, namelijk dat in plaats van die stukken, de Britsche regeering een schrijven zou uitlokken, waarop wij konden antwoorden, dat Nederland de bepalingen van de slaven-conventie met ernst beloofde te handhaven; een antwoord, hetwelk dan in stede van de instructiën, aan het Parlement kon vertoond worden. Wijl de ministers Falck en Van Nagell beiden de verzekering gaven, dat zoolang zij departementschefs bleven, geene schending van het tractaat meer zou plaats vinden, kon Clancarty zich met het voorstel vereenigen. Dientengevolge beloofde Falck er den Koning over te spreken.

Waarlijk, het was jammer, dat onze vorst, bij zoovele eigenschappen, die hem inderdaad tot koning stempelden, gebreken had, die hem in de oogen van een ieder tot een zéér klein man maakten.

Het ongeluk had gewild, dat onder de aan Clancarty verstrekte stukken, een door minister Falck onderteekend rapport was, waarin werd verwezen naar een particulier schrijven, dat men bovendien nergens meer kon vinden. Onze Koning nu was, gelijk De Bosch Kemper herinnert (b), "zeer gezet op orde en assiduiteit", doch ook hierin zonder voldoende maat. De ordezucht ontaardde in bureancratie en de assiduiteit in bemoeizucht. Dat foutje van Falck scheen

(a) Zie het rapport in bijl. 16 .

(b) Kemper 518 . 
Willem I enorm toe, zóó ernstig, dat hij waarlijk geloofde, dat zijn minister er zich over schaamde en dáárom eene poging aanwendde om de overlegging van de stukken aan het Parlement te verhoeden! Aangenomen eens, dat deze dwaze veronderstelling reden van bestaan had, moest dan de meester niet genoeg achting voor zijn eigen raadsman hebben gevoeld om te voorkomen, dat deze in den vreemde werd uitgelachen? - De Koning had echter voor het kleine in deze rol geen geopend oog; en aldus, rapporteerde Clancarty dd. 22 Januari 1822 naar Londen, liet Willem I de openbaarmaking der stukken toe, die slechts 's vorsten eigen onoprechtheid, "his own backwardness or awkwardness", in de nakoming der slaven-conventie aan den dag bracht $(a)$ !

Wanneer dan ook in het Eerste rapport der Staatscommissie, benoemd bij Koninklijk besluit van 29 November 1853, tot het voorstellen van maatregelen ten aanzien van de slaven in de Nederlandsche koloniën (b), getuigd wordt "dat gedurende eene lange reeks van jaren geen enkel geval van verboden slavenhandel onder Nederlandsche vlag is onderworpen geworden aan de rechtspraak van de krachtens het tractaat van den $4^{\mathrm{n}}$ Mei 1818 opgerigte gemengde geregtshoven te Paramaribo en Sierra Leona; en dat die geregtshoven, hoezeer niet uitdrukkelijk opgeheven, sedert eenige jaren door gebrek aan bezigheid hebben opgehouden te bestaan"; dan behoeft dit, ook in weerwil der mededeeling van Smulders, dat van 1819-1829 te Sierra Leona 21 Nederlandsche slavenhalers door Britsche kruisers opgebracht werden $(c)$, bij eene opvatting van het tractaat als wij hier leerden kennen, niet te verwonderen; doch betwijfeld mag worden, dat de sinds 1818 tot 1853 uitgevaardigde maatregelen en besluiten zouden bewijzen, "dat de afschaffing van den slavenhandel, voor zoover ons vaderland betreft, geene

(a) Zie bijl. 17 .

(b) 's-Gravenhage 1855.

(c) Bl. 43 noot 1. - Over het wederzijdsche onderzoek der slavenschepen, dat Castlereagh op het congres van 1818 te Aken ook aan de Franschen wilde opdringen, zeide minister Richelieu aan den Engelschen minister: „On . ne peut se dissimuler, que cette réciprocité de visite accordée aux Espagnols et aux Portugais ne soit à peu près illusoire, car qui pourrait imaginer que ces deux nations employassent le peu qui leur reste de moyens maritimes, $\grave{a}$ visiter sur les rivages africains, les vaisseaux anglais qui pourraient se livrer à la traite, tandis qu'ils ne pourraient garantir leurs propres cotes des déprédations des corsaires insurgés de l'Amérique du Sud." - Zie Richelieu 105. 
doode letter is geweest", gelijk Dr. J. Hartog, op gezag van dat rapport, vertrouwvol aanneemt $(a)$.

In ieder geval met de overlegging der slaven-instructiën aan den Britschen gezant in Januari 1822 meenden wij de hervatting van de koloniale onderhandelingen nu spoedig te kunnen verwachten, waarom minister Van Nagell dd. 18 Januari onzen ambassadeur schreef er ter gelegener tijd Castlereagh weer over te gaan spreken (b). Tien dagen later bracht Fagel een bezoek bij den Britschen minister. Deze zeide nu, dat hij nog niet had vernomen, dat de verwachte Bengaalsche stukken waren ontvangen. Zij konden dus wel ontvangen zijn! Zij waren inderdaad reeds verzonden bij brief van 17 Juni 1820, doch de ontvangst te Londen werd eerst erkend bij brief van 26 Januari 1822 (c). - Daar bovendien, naar wij weten, lord Moira zich niet de moeite had gegeven, Van der Capellen's klemmend betoog tegen de inbezitneming van Singapore te wederleggen, kon toch nog altijd gezegd worden, en dat werd gezegd, dat men naar zulk eene wederlegging bleef uitzien!

Nochtans had de Britsche minister geen bezwaar, om ook nu te verklaren, dat hij, evenals wij, naar de hervatting van de onderhandelingen haakte. Zelfs was, deelde hij mede - gelijk Fagel dd. 29 Januari 1822 aan Buitenlandsche Zaken rapporteerde president Wijnn gewaarschuwd, zoodat men de onderhandelingen spoedig te gemoet kon zien, hetwelk zeker zeer wenschelijk was, erkende de minister, omdat de toenemende ontwikkeling van Singapore het wegnemen van dezen steen des aanstoots steeds moeilijker maakte!! (d). Maar dat was immers juist, hetgeen de Engelsche regeering met haar tegenhouden van de onderhandelingen beoogde?

(a) Zie bl. 266 Juli 1899 Tïjdspiegel: „Uit de geschiedenis der bestrijding van de slavernij".

(b) Zie bijl. 18.

(c) Zie Singapore I 440-441; ov. 52-53.

(d) „J'ai parlé hier à lord Londonderry, mon cher Monsieur, aux termes de de votre lettre particulière du 18 , de la reprise de notre négociation Orientale. Il se rappelait très-bien la conversation que vous avez eue à ce sujet avee lui à Bruxelles. Il m'a dit qu'il désirait autant que nous que ces conférences recommençassent, mais qu'il n'avait pas encore appris que les dépêches, attendues de lord Hastings (de l'arrivée desquelles seule cela dépendait) eussent été reçues: qu'il avait déjà prévenu Mr. Wijnn de la probabilité de la prochaine reprise de cette négociation, qu'il lui en reparlerait, et me ferait savoir dès qu'ils seraient prêts ici: que la rentrée du Parlement n'y mettrait point d'obstacle, et qu'eux-mêmes désiraient d'autant plus terminer cette affaire, que restant toujours en possession de Singapoor et étant obligés à 
Den $5^{\text {n }}$ Februari 1822 kwam het Parlement voor het eerst onder een gewijzigd ministerie Liverpool-Castlereagh bij elkander; de zittingen duurden tot den $6^{\mathrm{n}}$ Augustus. Het bleek, dat de nieuwe regeeringsleden, onder wie ook een van Marine, weinig of niet tot versterking der regeering hadden bijgebracht; inzonderheid viel president Wijnn algemeen tegen $(a)$. Onder deze omstandigheden werd van Castlereagh's werkkracht meer gevorderd, dan voor de gezondheid van den reeds door de jicht gekwelden staatsman wenschelijk was.

Den $3^{\text {n }}$ Augustus gaf hij op zijn buitenverblijf te Cray een politieken maaltijd. Een der gasten, die den wijn wilde prijzen, riep hem aan met een "Lord Londonderry"! Verschrikt sprong de gastheer op en het kostte de aanzittenden moeite om hem weder rustig te doen plaats nemen. - De teekenen van vervolgingswaanzin schenen steeds duidelijker te spreken, toen Wellington, die weder naar de Nederlanden moest, zich ten huize van den minister te Londen vervoegde om afscheid te nemen. Castlereagh sprak met eene helderheid over de zaken, zooals zijn bezoeker nog nooit had opgemerkt. Midden in het gesprek voegde de minister hem echter toe: "Ten bewijze in welk gevaar ik verkeer strekke, dat mijne eigen bedienden het zeggen en dat ik onmiddellijk moet vertrekken; dat ik geen tijd heb te verliezen, en zij mijne paarden gezadeld houden, opdat ik er spoedigst van door kan; zij meenen, dat ik geen tijd zou hebben om in een rijtuig weg te komen." Hij schelde daarop een bediende: "Zeg me dadelijk, heerschap", voegde hij dezen toe, "wie liet mijne paarden hier komen; wie zond ze naar de stad?" — De man antwoordde, dat de paarden te Cray op stal stonden en niet in de stad waren.

In dezen staat ging de minister weder naar zijn buitenverblijf. Uit zijne omgeving in de ziekenkamer nam men op raad van den geneesheer pistolen en scheermessen weg. Doch in het aangrenzend vertrek lag een pennemes, waarvan zich de kranke wist meester te maken. In den nacht van zondag op maandag, den $12^{\mathrm{n}}$ Augustus 1822, sneed hij hiermede zich den hals door. (b)

y faire de la dépense, cette circonstance pourrait présenter quelque difficulté de plus, s'ils devaient nous rendre cet établissement.

„Je me trompe fort ou vous serez très-content des instructions de lord Londonderry au chevalier Bagot. Ce sont des modèles de sagesse et de modération." (B. Z.) - De laatste zinsnede handelt natuurlijk over eene andere zaak.

(a) "Charles Wijnn was universally admitted to have proved a failure". Walpole II 51.

(b) Zie o. a. Greville 51 vv. 
X.

\section{Vernieuwde pogingen in het tweede halfjaar 1822 en den aanvang van 1823 om minister Canning tot het hervatten der onderhandelingen te bewegen.}

In den tijd dien wij beschrijven, had de gouverneur-generaal van Britsch-Indië niet op rozen geslapen, en wel tengevolge van de aanraking met een handelshuis, waarover, zonderling spel van het toeval! ook zijn hooge ambtgenoot te Batavia in zekeren zin struikelen zoude. William Palmer heette een Britsch-Indisch officier, die den dienst had verlaten om te Hydrabad, waar hij in garnizoen had gelegen, een bankiershuis in 1814 te openen. De firma $W$. Palmer en $C^{0}$ verdiende o. a. veel geld met het geven van voorschotten aan de regeering van den vorst aldaar, den z. g. Nizam. Het was weliswaar bij parlementsacte verboden, dat Britsche onderdanen leeningen met inlandsche vorsten aangingen; maar de Gouv.-Gen. in Rade maakte in 1816 van eene hem op wetgevend gebied toegekende discretionnaire bevoegdheid gebruik om de firma van dit verbod te ontheffen. Lord Moira stelde inderdaad belang in den bloei dier firma, omdat een zijner bloedverwanten, de heer Rumbold, er lid van was; doch overigens had, naar het schijnt, de landvoogd slechts de voor de onderneming gunstige beslissingen genomen in de gemoedelijke meening, dat de werkzaamheid er van aan Hydrabad zelf ten goede kwam. Aanzienlijke leeningen werden dientengevolge gesloten, toen in 1820 de directie te Londen hare hooge afkeuring uitsprak, én over de leeningen zelven, én over Moira's uitzonderingsverordening. Men beschuldigde hem niet onduidelijk van, ten koste der toevertrouwde belangen, uit onedele beginselen, voor het verkeerde van Palmer's transactiën het oog te hebben gesloten, zoodat hij zich verplicht achtte in 1821 zijn ontslag aan te bieden. (a)

(a) Over de transactiën van Palmer en $\mathrm{C}^{\circ}$ in Hydrabad en de gevolgen, die ze voor lord Moira hadden, zie men o. a. Wilson II $486 \mathrm{vv}$. "It is not to be denied", leest men er bl. 502, "that the personal interest taken in the successful operations of the house, the ready acquiescence with which their applications and representations were received, and the reluctance to admit anything in their disfavour until it could no longer be disputed that they had taken undue advantage of the confidence which had been shown them, were incompatible with the duties of the Governor-General, were an 
Voor het Londensch bestuur was de keuze zijns opvolgers spoedig eene uitgemaakte zaak. Wij lazen op bl. 99-100 met hoeveel waardeering de directie lord Canning als haar president had laten heengaan, nu meende men geene betere benoeming te kunnen doen dan hem als landvoogd uit te zenden. Doch belanghebbende zelf weifelde. Zijn ideaal was leider van eene partij in het Parlement, te schitteren door welsprekendheid, door zijne groote gaven als minister. Dat ideaal zou wellicht voor goed ondergaan in eene landvoogdij, waarvoor hij zich minder op zijne plaats achtte. Er was echter niets anders en er scheen ook geene kans op verandering, zoolang Castlereagh leefde. Hij nam dus de benoeming eindelijk aan, doch draalde zoolang met zijn vertrek, dat toen hij ten slotte gereed stond heen te gaan, de mare van Castlereagh's plotselingen dood zich verbreidde.

Het ministerie verkeerde in groote verlegenheid. Er was slechts één man in de Tory-partij, die niet slechts voor de vervanging van Castlereagh geschikt scheen, maar in velerlei opzichten hem kon overtreffen; dien éénen echter, op wien een ieder het oog gevestigd hield, wilde koning George IV niet. De vorst toch kon Canning's houding in de Koninginne-zaak niet vergeven. Eindelijk werd Wellington, lid van het ministerie, er op afgezonden om den Koning tot andere gedachten, goed- of kwaadschiks! te brengen ....

- "Goeje God!", riep de Koning hem toe, "Arthur, je meent het toch niet om me dien man als secretaris van Staat voor Buitenlandsche Zaken voor te stellen. Dat is onmogelijk. Neen, ik zeg op mijne eer als een gentleman, nooit zal hij weer een van mijne ministers worden. Je hoort het, Arthur, op mijne eer als een gentleman. Ik ben zeker, dat je het met me eens zult zijn. Ik kan niet doen, wat ik op mijne eer als een gentleman gezegd heb, nooit te zullen doen."

- "Houd het mij ten goede, Heer", antwoordde de aldus toegesprokene, "ik ben het volstrekt niet met $\mathrm{u}$ eens; Uwe Majesteit is geen gentleman."

De Koning schrok op; maar Wellington vervolgde:

- "Uwe Majesteit, zeg ik, is geen gentleman, maar de souverein van Engeland, met plichten jegens uw volk, ver verheven boven die jegens u zelf; en deze plichten maken het gebiedend nood-

injudicious departure from the caution which experience of the past had suggested in regard to pecuniary transactions between Europeans and Natives of rank, were detrimental to the ally whom it was intended to serve, and subjected the Company to serious embarrassment and loss." 
zakelijk, dat u op het oogenblik de bekwaamheden van den heer Canning benut."

— "Goed dan!" luidde het met eene zware zucht, "indien ik moet, moet ik." (a)

Nog een oogenblik scheen een finale breuk te dreigen tusschen den Koning en den tegen diens zin opgetreden minister, tengevolge van een brief aan den chef van het kabinet, lord Liverpool, waarin de vorst, na zijn onderhoud met Wellington, schreef, dat het hem behaagde Canning vergiffenis te schenken of letterlijk: "to extend his grace and favour to a subject who may have incurred his displeasure". Lord Liverpool had de onvoorzichtigheid dit stuk te laten lezen. Niet alleen Canning was woedend, doch ook mevrouw Canning en juffrouw Canning. Een nijdige brief aan lord Liverpool om er den Koning van inzage te doen nemen, lag reeds gereed, toen men de opgewonden familie tot bedaren wist te brengen en haar verklaarde, dat in die woorden niets beleedigends gelegen lag. Het antwoord werd in het vuur geworpen en weldra bleek geen departementschef zoo bevriend met George IV als George Canning! (b)

Ter nauwernood was hij als minister opgetreden, of ten onzent rees opnieuw de gedachte om bij het Britsch bewind stappen voor de hervatting van de onderhandelingen te doen. Minister Falck achtte namelijk het herzien der conventie van 1814, blijkens zijn rapport dd. 17 September 1822 aan den Koning, steeds gewenscht. Hij gaf toe, dat de omstandigheden, die tot zijn voorstel van April 1821 hadden geleid (bl. 108), eenigszins veranderd waren; want destijds had ons prestige onder den fatalen indruk van Singapore's stichting geleden, terwijl die indruk sedert, dank onze overwinningen in Palembang, geheel was uitgewischt; maar, oordeelde de minister: "Men behoort te denken aan de toekomst,

(a) Characters 324. - George IV noemde zichzelf ,the first gentleman in Europe". Walpole, dit mededeelende (I 247) voegt er aan toe: „Unfortunately, the language which he habitually used, the habits to which he was constantly addicted, and the scenes which he frequented, made the title appear like a sarcasm. Yet there were occasions when he showed that he could thoroughly deserve his self-imposed title. He knew how to captivate genius like that of Scott, or piety like that of Wilberforce. But the Regent, in company with Scott and Wilberforee, was in reality only acting a part, and proving himself, in doing so, a consummate actor. On ordinary occasions he placed no restraints either on his actions or on his tongue. The first gentleman in Europe thought it an admirable joke to make a duke as drunk as himself; he saw nothing indecorous in the use of language which was hardly fit for his stable."

(b) Greville 58--59. 
en, afgezien zelfs van de ontwerpen van commerciëel overwigt in den Maleischen Archipel, raadt de voorzigtigheid aan, om de aanleiding weg te nemen tot plaatselijke geschillen, die in overzeesche gewesten zoo ligtelijk tusschen de Gezaghebbers der wederzijdsche bezittingen rijzen en, vervolgens, zooals de geschiedenis leert, tot hooger overslaande, de Gouvernementen in ernstige moeijelijkheden wikkelen" (a). - Het voorstel, gesteund door minister Van Nagell, werd door den Koning aanstonds ernstig opgenomen. Niet alleen toch schreef het besluit dd. 1 October 1822 Buitenlandsche Zaken aan, om onzen gezant te Londen de noodige opdracht te doen; doch tevens werden de beide departementschefs van Koloniën en Buitenlandsche Zaken gelast om nader te overwegen, in hoever de op bl. 73 vermelde instructie van 1820 herziening vorderde $(b)$.

Fagel bevond zich den $8^{n}$ October 1822 bij Canning, ten einde over de zaak te spreken. Het uitblijven der Bengaalsche stukken kon niet meer eene reden tot wachten zijn, daar zij eindelijk waren ontvangen; men verklaarde zich dan ook bereid onmiddellijk de conferentiën te openen. En waarom gebeurde het dan toch niet?... De minister, aldus rapporteerde Fagel nog denzelfden dag aan Buitenlandsche Zaken, wilde nu liever eerst wachten op de terugkomst te Londen van den Bengaalschen landvoogd zelven, lord Moira, die dagelijks kon worden te gemoet gezien! (c)

En hiermede werd onze ambassadeur andermaal afgescheept, terwijl de markies van Hastings hoog en droog in Bengalen zat! Immers, na reeds in 1821 ontslag te hebben gevraagd, maakte de landvoogd zieh pas op het einde van het volgende jaar tot vertrek gereed,

(a) Ambtsbrieven $148 \mathrm{~N}^{\mathrm{e}} 22$.

(b) $B i j d r . ~ E . ~ 167$.

(c) ${ }_{n} \mathrm{Je}$ viens d'entretenir Mr. Canning aux termes de la dépêche de V. E. $\mathrm{N}^{\circ} 121$ du 4 de ce mois du désir du Roi, que les négociations sur les intérêts mutuels aux Indes Orientales soyent promptement reprises. Son Excellence m'a répondu de suite qu'on était très disposé ici à accéder à ce désir, mais que pour fixer le moment de cette reprise il souhaiterait à présent d'attendre qu'on ait reçu la nouvelle, qu'on attend d'un jour à l'autre, du retour du marquis de Hastings en Europe.

„J'ai trouvé Mr. Canning désagréablement préoccupé de l'affaire de la frégatte La Lutine, dont il me parla avec un peu de chaleur au moment même où j'étais entré chez lui, et où j'allais faire mention du sujet qui m'y avait amené. J'apprends de lui que lord Clancarty est attendu ici incessamment et ne retardera pas à se rendre à son poste." (B. Z.) 
daar hij eerst dd. 1 Januari 1823 zijne waardigheid nederlegde $(a)$. Dat ook daarbij geenerlei kieschheid werd betracht ten aanzien van onze rechten op Singapore deelde ik elders mede $(b)$.

Toen het tijdstip van Moira's vertrek naar Europa naderde, verbreidde zich bovendien het gerucht, dat de afgetreden landvoogd in den eersten tijd wel niet naar Engeland zou oversteken. Zoo langzaam mogelijk maakte hij inderdaad de reis over land en, in het zuiden van Europa gekomen, waagde hij zich niet verder. Het zonderlinge geval deed zich voor, dat in Engeland eene menigte schuldeischers er op loerde om hem bij aankomst te vervolgen: zeker een, zij 't ook wel wat al te plastisch bewijs, dat hij zich met zijne bescherming aan Palmer en $C^{\circ}$ niet verrijkt had, gelijk men gezegd had, dat het geval was geweest.

Fagel, in voldoening aan eene nieuwe lastgeving van Buitenlandsche Zaken betrekkelijk de hervatting van de onderhandelingen, deelde dd. 27 December 1822 mede, dat de Engelsche regeering den zwervenden staatsdienaar tot haren vertegenwoordiger te Napels zou benoemen $(c)$. Lord Moira werd echter in 1824 gouverneur van Malta, waar hij twee jaar later overleed, het eigenaardig verzoek nalatende, dat zijne rechterhand zou worden afgehouwen en bewaard tot ook zijne gade stierf, als wanneer de hand in hare doodkist mede ter aarde moest besteld worden $(d)$.

Welk een indruk het bericht van onzen gezant maakte, dat lord Moira vermoedelijk niet eens in Engeland zou komen, kan hieruit

(a) "The Marquis of Hastings quitted his government on the $1^{\text {st }}$ of January, 1823." "In the interval that elapsed between the departure of the Marquis of Hastings in January, 1823, and the arrival of Lord Amherst in the August following, the Government devolved upon the senior member of Council, Mr. John Adam." Bl. 587 dl. II en bl. 5 dl. III Wilson.

(b) Singapore II $354-355$; ov. $42-43$.

(c) „J'ai reçu dès hier les dépêches de V. E. de l'avant veille, $\mathrm{n}^{\text {os }} 157$, 158,159 et 160 du 24 de ce mois.

„Le marquis de Hastings, Gouverneur-Général de l'Inde Britannique, est attendu en Europe vers la fin du mois prochain. On assure qu'il fait le voyage par terre. Ce qui paraît moins douteux est, qu'il ne viendra pas dans ce pays-ci, où il serait de suite arrêté pour dettes. L'on prétend qu'il ira en droiture à Naples, et qu'il y restera en qualité de ministre Britannique. Comme cette mission n'est point une ambassade, et ne saurait le devenir à une occasion telle que celle-ci, il serait assez extraordinaire de voir un ei-devant Gouverneur-Général des Indes résider, comme ministre du second rang à une cour qui, elle-même n'occupe pas le premier parmi celles de l'Europe." (B. Z.)

(d) Encyclopaedia Britannica in voce. 
blijken, dat niet alleen minister Van Nagell uit zich zelven den heer Fagel opdroeg om alsnog Canning er over te spreken, doch dat, onafhankelijk hiervan, de Koning er Buitenlandsche Zaken over deed schrijven. Ook de toon der correspondentie van het Engelsch bewind bleef onzen vorst grieven, waaraan deze tegelijkertijd uiting deed geven in een renvooi dd. 2 Januari 1823, houdende terugzending van stukken aan den minister. Evenals vroeger (bl. 111), liet de Koning namelijk vragen: "of het niet, ten einde het ontvangen van dusdanige min aangename nota's als de hier bedoelde, voor het vervolg voor te komen, als doelmatig zoude kunnen worden beschouwd, om de antwoorden op de nota's van de Engelsche ambassade alhier aan het Engelsche gouvernement zelf, door tusschenkomst van $\mathrm{Z}^{\mathrm{r}} \mathrm{M}^{\mathrm{s}}$ ambassadeur te Londen te laten geworden"; terwijl over de onderhandelingen het volgende stond opgemerkt: "Daar de depêche uit Londen van den 27 ${ }^{\mathrm{n}}$ December $1822 \mathrm{n}^{0} 196$ melding makt van de aanstaande komst in Europa van den Gouverneur-Generaal van Britsch-Indië, zonder dat hij Engeland zoude aandoen, en er steeds door het Engelsch gouvernement naar het tijdstip van het bekomen van nadere inlichtingen door dien Gouverneur zelf te geven, is terug gewezen, alvorens tot eene finale regeling der Nederlandsche en Engelsche belangen in Indië te kunnen overgaan, doet Z. M. insgelijks aan Uwe Excellentie in bedenking geven of deze omstandigheden geene gepaste gelegenheid zouden kunnen aanbieden, om bij het Engelsche gouvernement te doen aandringen ten einde door het vervolgen der eens aangeknoopte onderhandelingen tot eene afdoening van zaken in deze te geraken."

Fagel had bereids dd. 3 Januari 1823 op Van Nagell's aanschrijving geantwoord, dat hij zeer zeker bij Canning op de zaak zou terugkomen, zoodra het vast stond, dat lord Moira er van afzag naar Engeland over te steken $(a)$; en den $10^{\text {n }}$ d.a.v. schreef hij nog particulier aan Elout, zonder geheel den moed te hebben verloren: "Ik had mede wel gewenscht, dat onze afgebrokene Confe-

(a) „Hier j'ai reçu les dépêches de Votre Excellence du 31 Décembre $\mathrm{n}^{\text {os }} 162$ et 163 . J'ai l'honneur de la remercier de la communication des pièces jointes à la seconde. Si le Marquis de Hastings, à sa prochaine arrivée en Europe, ne revient point en Angleterre, Votre Excellence peut compter que je ne perdrai pas de temps pour adresser à Mr. Canning la question fort naturelle à laquelle cette circonstance donnerait lieu, sur ce que deviendraient dans ce cas nos négociations, dont Mr. Canning a proposé de différer la reprise jusqu'au retour du noble marquis en Europe. Je pense au reste que la présence de Sa Seigneurie en Angleterre ne serait pas indispensable 
rentiën spoediger hervat hadden kunnen worden, en heb niets verzuimd om daartoe te geraken. De Markies Hastings wordt dagelijks in Europa terugverwacht, en men belooft ons alsdan weder aan het werk te zullen gaan. Ik heb eenige reden te vermoeden, zonder het echter met gewisheid te weten, dat er inderdaad een antwoord van hem over de vraag aangaande Sinkapore ingekomen is, en dat het voor ons niet ongunstig was, doch dat men hier verdere inlichtingen verlangd heeft." (a)

De gezant kwam intusschen niet verder. Toen Fagel vervolgens voor korten tijd zelf naar Nederland overkwam, nam hij slechts de overtuiging uit Londen mede: "dat men in Engeland de zaak liefst op den langen baan geschoven zag". Nochtans waren Fagel's mondelinge mededeelingen, die hij uit Engeland overbracht, van de gewichtigste gevolgen.

XI.

\section{Het besluit tot het hervatten der onderhandelingen in de laatste helft van 1823.}

Was toch door Canning rondweg verklaard, dat hem eene hervatting der onderhandelingen niet meer noodig scheen, hij had zich tegenover Fagel evenmin volstrekt afwijzend ten deze uitgelaten, indien de Nederlandsche regeering bij hare wenschen bleef; alleen beval hij dan als plaats van onderhandeling 's-Gravenhage boven Londen aan, wegens den druk dien men in Engelands hoofdstad op de beoordeeling der zaken kon uitoefenen. - Onze staatslieden meenden van deze gezindheid te moeten gebruik maken; althans wat betreft de herziening van het tractaat van 1814; niet echter wat aangaat de verandering van plaats der samenkomst, daar aldus gevaar werd geloopen, vreesde men te 's-Gravenhage, als Britschen gevolmachtigde te zien aangewezen den Engelschen ambassadeur, lord Clancarty, uit wiens militant optreden men weinig goeds voor de besprekingen voorspelde. Onzerzijds zoude daarom getracht

pour recommencer ces négociations, auxquelles je ne crois pas qu'il s'agisse de lui faire prendre une part directe. Ce que Mr. Canning a voulu dire, à ce que je présume, est que le retour de Sa Seigneurie étant très-prochain, on aimerait ici attendre son arrivée afin de pouvoir d'autant plus aisément avoir recour à ses lumières, et lui demander des éclaircissements, qu'il serait bien plus facile d'obtenir de lui en Europe que dans l'Inde." (B. Z.)

(b) Bïdr. E. 168-169. 
worden, Canning over te halen tot de keuze van Londen zich te blijven bepalen, en om hem over dezen afwijkenden wensch - die den minister vermoedelijk geheel onverschillig zal gelaten hebben, nu wij zelven voor het belang van de nieuwe onderhandelingsplaats weinig bleken te gevoelen — niet uit zijn humeur te brengen, zouden wij hem een wenk geven, dat wij eigenlijk om Singapore niet meer gaven. Inderdaad, Falck overtuigde Van Nagell, dat wij noch aan deze plaats, noch aan Malakka veel zouden hebben; het eene konden wij gerust prijsgeven, het andere best tegen goede ruiling afstaan. Het was op deze allertreurigste gronden, dat de Koning in Augustus 1823 zijn minister van Buitenlandsche Zaken last gaf, onzen ambassadeur te Londen op te dragen, den Britschen minister tot het doen heropenen van de onderhandelingen te bewegen. $(a)$

Bij missive dd. 23 Augustus 1823 zond minister Van Nagell de bevolen opdracht in den vorm eener Memorie van instructie aan gezant Fagel. Als inleiding werd in de ons reeds bekende bewoordingen uiteengezet, waarom men dezerzijds aan Singapore minder was gaan hechten; verder dat de Koning de voortzetting der beraadslagingen te Londen verkoos boven de verlegging er van naar Nederland: "om redenen, die mondeling door den ondergeteekenden minister van Buitenlandsche Zaken aan den heer Ambassadeur zijn kenbaar gemaakt". Op grond van een en ander werd de gezant gemachtigd, den heer Canning te kennen te geven: "dat, hoezeer de zaken in Indië zich over en weder van de Ned. en Eng. zijden tegenwoordig rustig toedragen, het aan het Ned. Gouv. niettemin hoogst wenschelijk is voorgekomen, dat de hangende bezwaren definitief worden uit den weg geruimd, opdat de goede verstandhouding in die streken bevestigd en bestendig bewaard blijve en dat tot dit einde de in 1820 met wederzijdsche welwillendheid begonnen onderhandelingen te Londen worden voortgezet; mitsgaders, dat vermits door hem, heer Canning, is aangemerkt, dat de zaak van Singapore eene onoverkomelijke zwarigheid schijnt op te leveren, hij uit het besluit van Zijne Majesteit zelf, om de onderhandelingen ter plaatse, waar die zijn aangevangen, wederom aan te knoopen, zal kunnen opmaken, dat men van de Ned. zijde niet ongenegen is de vermeende onoverkomelijke hinderpaal, zoo mogelijk uit den weg te ruimen." Tevens moest de gezant in herinnering brengen: "dat in 1820 , tot overweging van de territoriale ruilingen, een

(a) Zie in het breede over deze jammerlijke aangelegenheid, Singapore $\amalg$, hoofdstuk VII. 
geheim commité uit bewindhebbers der Eng. O. I. C. is benoemd geworden en dat het om nieuwe vertragingen voor te komen, alleszins te wenschen is, dat het rapport deswegen moge ingekomen zijn, alvorens de onderhandelingen wederom worden aangevangen".

Den $13^{\text {n }}$ September 1823 des morgens bracht Fagel een bezoek aan den Britschen minister, bij welke gelegenheid de treurige boodschap werd overgebracht. Canning was natuurlijk in zijn nopjes. Het rapport van het Comité der O. I. C. zou hij aanstonds opvragen, en zoodra hij het kon zenden, beloofde de minister, het tijdstip voor de hervatting der onderhandelingen mede te deelen, berichtte nog denzelfden dag onze gezant aan Buitenlandsche Zaken. Is bij mij wel eens de vraag gerezen, of werkelijk aan Canning de wenk betreffende Singapore werd gegeven, het blijkt ons nu uit Fagel's rapport, dat daaraan niet meer getwijfeld mag worden; hoe is het mogelijk! (a)

Een tiental dagen later volgde het bericht, dat men in November kon beginnen; eerder ging het niet, deelde Fagel dd. 23 September 1823 Buitenlandsche Zaken mede, doordien zoowel het personeel der departementen als de ministers, onder wie Canning zelf, uit de stad gingen (b).

(a) Ik uitte mijn twijfel, ook in verband met de woorden der Additioneele punten van instructie, waarin de handhaving van ons recht op Singapore nog zoo sterk wordt uitgesproken, blijkens Singapore II bl. 383; ov. 71; maar zie hier de eigen woorden van Fagel's rapport:

„Mr. Canning reçut cette ouverture aveo bienveillance, me disant que dès lors que l'article de Singapour pourrait ne plus être regardé comme présentant un obstacle insurmontable, il ne désespérait plus du succès de la négociaticn; qu'il se ferait informer aux bureaux de la Compagnie des Indes où l'aftaire en était restée, nommément par rapport aux échanges projétés de territoires (circonstance que je lui rappelai en vertu de l'instruction précitée) et que dès qu'il aurait obtenu ces informations, il m'en ferait part afin de convenir de l'époque où les conférences pourraient être reprises îci à Londres." (B. Z.)

(b) „Mr. Canning m'informa, Samedi passé, dāns un entretien que j'eus avec lui ce jour-là, qu'il n'avait pas encore reçu de la Compagnie des Indes Orientales, les informations, dont il est question dans mon rapport secret $\mathrm{n}^{\circ} 149$ du 13 de ce mois et qui sont relatives à nos négociations sur les affaires des Indes Orientales, mais qu'il les attendait d'un moment à l'autre. Il me dit de plus qu'en tout état de cause ces conférences ne pourraient être reprises avant la fin de Novembre, tous les employés du Gouvernement, ainsi que la plupart des Ministres étant en vacances. Mr. Canning lui-même se dispose à quitter Londres le 3 ou le 4 du mois prochain pour faire une course dans le comté de Devonshire aux environs de Plymouth. Il ne sera de retour que vers la mi-Novembre". (B. Z.) 
Den $27^{\mathrm{n}}$ September begaf Fagel zich andermaal naar Canning, om zich vóór 's ministers vertrek nog te overtuigen, dat men nu werkelijk op de gestelde maand zou kunnen rekenen. De minister bleef hem hiervan de verzekering geven; hij verzocht tevens eene nota te mogen ontvangen omtrent den staat der zaak, waarin die bij het afbreken der onderhandelingen van 1820 was gelaten; wederkeerig beloofde hij er een aan het bestuur der Oost-Indische Compagnie te verzoeken en ons te geven. Men kon dan beide stukken vergelijken. - Reeds nu bleek onwillekeurig, dat het lang niet zoo kwaad zou geweest zijn, indien men in Nederland de werkzaamheden had hervat. Fagel toch schreef dd. 28 September aan Buitenlandsche Zaken, dat hij de Nota wel zou kunnen opmaken, doch dat daartoe, naar zijn oordeel, Elout beter in staat was, of met diens hulp, Falck, aangezien de stukken zich in Nederland bevonden $(a)$.

Van Nagell wendde zich hierover bij schrijven dd. 8 October tot zijne ambtgenooten. Zij voldeden aan het verzoek niet alleen, doch Falck stelde tevens de punten van instructie op, die ter aanvulling moesten strekken van de aan de gevolmachtigden in 1820 medegegeven instructie. Art. 1 teekende de onderwerpen aan, die als resultaat der samenkomsten van 1820 voor aangenomen bleven beschouwd. Art. 2 merkte op, dat Baros en Ajer Bangis wel buiten behandeling zouden blijven, wijl de Engelschen deze kantoren ten slotte toch hadden ontruimd en er sinds geen verschil over was gerezen $(b)$. De artt. 3 en 4 handelden over Singapore, namelijk om met de meeste kracht de ontruiming te vorderen; en dat, terwijl de ontwerper zelf had medegewerkt om Canning een wenk te doen

(a) „Mr. Canning me dit qu'il prendrait avant son départ les mesures préliminaires réquises pour que nos conférences sur les intérèts réciproques dans l'Inde puissent être ré-entamées sans faute vers la fin de Novembre. Des plénipotentiaires Britanniques seront nommés à cet effet, et $\mathrm{Mr}$. Canning serait fort obligé à Votre Excellence de vouloir engager $\mathrm{Mr}$. Elout à lui faire passer, par mon entremise, une note dans laquelle serait exposé, en peu de mots, l'état où nous avons laissé la discussion lorque nos conférences furent interrompues au mois d'Aôt 1820. Je pouvais jusqu'à un certain point fournir cette information à l'aide de la correspondance de la dite année 1820; mais je crois qu'il vaut infiniment mieux que Mr. Elout ou (de concert avec lui) Mr. Falck prenne cette peine. La notice en question sera plus précise, et dressée avec plus de connaissance de cause. Mr. Canning de son côté recevra une note pareille de la Compagnie des Indes ou du Board of Control." (B. Z.)

(b) Zie over deze quaestie Sumatra's Westkust II 225-237; ov. 21-33. 
geven, dat wij niet op de ontruiming zouden blijven staan! Blijft mij deze opvatting onverklaarbaar, bij art. 5 vergiste zich de heer Falck ten eenenmale. Het gebood uitdrukkelijk, dat in geen voorstel tot opheffing van differentieele rechten mocht worden getreden. De minister verkeerde in de meening, dat er door de Engelsche gevolmachtigden van 1820 op was aangedrongen, om de rechten steeds voor de wederzijdsche bezittingen in Azië gelijk te houden; doch, zooals de ontwerper in den loop der onderhandelingen zou ontwaren, van Engelsche zijde was nooit dergelijk denkbeeld geopperd en zou het ook niet geopperd worden. De vergissing wijst er op, dat Falck niet zó op de hoogte der zaken kon geacht worden, als wel wenschelijk ware geweest $(a)$. Het slotartikel 6 gelastte om in geen geval een voorstel tot toelating van consuls aan te nemen.

Falck had zijne ontwerp-instructie dd. 20 November ambtgenoot Van Nagell aangeboden, ter doorzending aan den Koning. Deze ontving het den volgenden dag, vergezeld van een concept-besluit tot benoeming van Falck als gevolmachtigde; hij zou vergezeld worden door den heer $O$. W. Hora Siccama, een neef van Falck, als amanuensis $(b)$. Van meer belang dan het medegeven van dezen ondergeschikte, was de toevoeging van een kapitein van het OostIndische leger, met verlof in Nederland, C. P. J. Elout, zoon van den toenmaligen minister van Financiën. Noch Fagel, noch Falck bezat, naar wij weten, van de Oost-Indische zaken diepe kennis, en beiden misten volstrekt plaatselijke ervaring. De oud-Commissaris-Generaal had die leemte kunnen aanvullen. De Koning wilde hem echter als minister van Financiën niet missen; dat dit met Falck juist wèl het geval was, zette ik elders uiteen $(c)$. Ten einde in het gebrek aan plaatselijke kennis te voorzien, werd de zoon van den oud-Commissaris-Generaal, gewezen adjudant van den gouverneurgeneraal Van der Capellen en die reeds een goed verleden in Indië achter zich had, aangewezen.

De benoeming van Falck tot onderhandelaar, nevens Fagel, met de toevoeging van kapitein Elout had bij Koninklijk besluit

(a) Falck erkende zijne dwaling in een brief dd. 1 Februari 1824 uit Londen aan den Koning geschreven. Het stuk is opgenomen in de Ambtsbrieven op bl. 186 No 2 , doch met het verkeerde, op een dwaalspoor brengend jaartal 1834.

(b) Deze heer werd ook op bl. 8 onder 16 genoemd.

(c) Zie Fagel's Ontslag 407; ov. 15. 
van 21 November 1823 plaats (a); tegelijkertijd werden de Additioneele punten van instructie vastgesteld $(b)$.

\section{XII.}

\section{De Londensche onderhandelingen in December 1823- Januari 1824.}

Terwijl onze regeering in Europa zoo vele jaren te vergeefs moeite had gedaan om tot eene hervatting van de onderhandelingen te komen, stoorde men zich van Engelsche zijde in Azië volstrekt niet aan het tusschen de landvoogden te Calcutta en Batavia afgesprokene om de Singapoorsche zaken nu te laten zooals ze waren tot eene conventie in Europa aan de geschillen een einde had gemaakt. Ten slotte zag de gouv.-gen. Van der Capellen zich genoodzaakt in Mei 1823 tot een ernstig protest, terwijl hij te gelijker tijd er het ministerie van Koloniën kennis van gaf $(c)$. Dit ontving de stukken nog vóór den aanvang der onderhandelingen, zonder dat het echter blijkt, ze daar ter sprake zijn gekomen, ofschoon de Koning er machtiging toe had gegeven $(d)$.

Den $26^{\mathrm{n}}$ November 1823 verliet hiermede de dd. 21 te voren benoemde plenipotentiaris Falck met zijn gevolg Rotterdam. Intusschen had Fagel denzelfden $21^{\mathrm{n}}$ bericht, dat weliswaar in de tweede helft dier maand bijna al de Britsche ministers waren teruggekeerd, doch

(a) Het benoemingsbesluit in bijl. 19; het doet tevens ons zien, hoeveel moeite onze administratie had om met de Nederlandsche taal op ordentelijken voet te komen; verg. bl. 111. Op bl. 51 zegt Smulders, dat bij koninklijk besluit van 12 Juni 1823 tot gevolmachtigden werden benoemd Falck en Fagel. Onjuist is deze datum; ook onjuist dat Fagel benoemd werd. De Regeering hield het er namelijk voor, dat Fagel nog altijd gevolmachtigde was, krachtèns de koninklijke benoeming van 1820. Alzoo is correet de mededeeling boven op bl. 181 van Falck's Ambtsbrieven: „Bij 's Konings Besluit van 21 November 1823 la Z10 geheim, werd Mr. A. R. F. benoemd tot H. D. Plenipotentiaris om gezamenlijk met den als zoodanig bij Besluit van 12 Junij 1820 no 35 benoemden Ambassadeur bij het Hof van Londen, den Baron H. Fagel, de in datzelfde jaar reeds gestakkte onderhandelingen over de Oost-Indische Zaken ten einde te brengen." - Smulders' beide fouten zijn door Meinsma overgenomen.

(b) Zonderling dat deze belangrijke bijdrage tot de kennis van het tractaat van 1824 door de Elout-bijdragen slechts in substantie wordt weergegeven (op bl. XXIII der inleiding), waardoor men geenszins op de hoogte komt van den geest dezer voorschriften. De lezer kan ze nu vinden in Singapore II bijl. 17 .

(c) Zie breeder hoofdstuk IV van Singapore II.

(d) Zie breeder Singapore II 383; ov. 71 .

7• Volgr. II. 
dat de mogelijkheid van nieuw uitstel geenszins bleef uitgesloten. De London Gazette van 18 November had namelijk het parlement tegen 3 Februari 1824 bijeengeroepen, als wanneer de Britsche gevolmachtigden naar gewoonte niet beschikbaar zouden zijn. Men behoorde dus den tijd te gebruiken tusschen November en Februari, schreef de ambassadeur; maar hij was nog niet in de gelegenheid geweest, om Canning over den aanvang der onderhandelingen te spreken, daar de minister door werkzaamheden en ziekte op zijn buitenverblijf te Gloucester Lodge bij Londen teruggehouden werd $(a)$. De post bleef echter door slecht weder lang onderweg, zoodat Falck reeds op reis was toen de brief zijne bestemming bereikte en onze gevolmachtigde na eene zeer voorspoedige reis van 30 uur, onverwacht den $27^{\mathrm{n}}$ November voor Fagel stond. Maar wel verre, dat een hartelijk welkom den bezoeker te gemoet klonk, trof deze den ambassadeur in een wanhopenden toestand aan. Ziehier de oorzaak.

Koning Willem I vond de legatie te Londen met een ambassadeur aan het hoofd te duur, doch kon bezwaarlijk Fagel tot den lageren rang van gezant degradeeren. Toen ik dit elders beschreef, heb ik in gemoede vermeend, dat dit werkelijk de reden was, die aan verandering deed denken $(b)$; doch de lezing van La Révolution Belge de 1830 van Théodore Juste geeft een eenigszins ander zicht op deze zaak. De Koning namelijk kon lord Clancarty niet langer uitstaan, en om nu Engeland te dwingen hem te verwijderen, zou de rang van den Nederlandschen vertegenwoordiger te Londen verminderd worden, in welk geval de Britsche regeering wel met hąar vertegenwoordiger hetzelfde zou moeten doen, dat dan

(a) „Je n'ai pas encore réussi à voir Mr. Canning à cause de ses occupations depuis son retour, et de son indisposition, mais je ne tarderai pas à avoir une conférence avec lui. Un des premiers objets dont je l'entretiendrai sera, comme de raison, celui de la reprise de notre conférence avec les affaires des Indes. Je prends la liberté de rappeler à ce sujet à Votre Excellence $\mathrm{Sa}$ dépêche $\mathrm{N}^{\circ} 133$ du 3 Octobre dernier, où Elle me fait l'honneur de me marquer (en réponse à ce que je Lui avais mandé dans mon $\mathrm{N}^{\circ} 157 \mathrm{du}$ 28 Septembre précédent) qu'Elle ne doutait pas que Messieurs Elout et Falck, déférant au désir exprimé à cet égard par Mr. Canning, ne fournissent à Votre Excellence la Note, demandée par le Ministre Britannique sur l'état dans lequel cette négotiation avait été laissée á l'époque où elle fut suspendue en 1820." (B. Z.)

(b) In Fagel's Ontslag 404, ov. 12: „Koning Willem I meende echter, en niet ten onrechte, dat die belangen wel op eenigszins goedkooper wijze waren toe te vertrouwen, dus aan een vertegenwoordiger van lageren rang." - $\mathrm{Zie}$ ook de noot op bl. 395 aldaar; ov. 3. 
slechts kon geschieden met overplaatsing van lord Clancarty (a). - Inmiddels kreeg de Koning eene gelegenheid, Fagel van Londen terug te roepen. Minister Van Nagell had er namelijk op gestaan met het einde van 1823 af te treden; tot diens opvolger wenschte de vorst onzen Londenschen gezant. Ofschoon ongaarne den schoonen post verlatende, zag Fagel zich tegenover 's Konings voornemen tot bezuiniging wel genoodzaakt toe te geven en eene andere hooge staatsbetrekking aan te nemen, die hem wel niet aanstond, maar in ieder geval eene positie bleef verzekeren.

Hetzij echter omdat het vrijwillig vertrek van Clancarty het voorwendsel der bezuiniging niet meer noodig maakte, hetzij omdat de koning van Engeland onze Regeering deed weten, dat men het aanwezen van een Nederlandsch vertegenwoordiger met den rang van "ambassadeur" op prijs bleef stellen, - onze Koning gaf het bezuinigingsdenkbeeld op. Fagel nog te Londen dit vernemende, had nu berouw de portefeuille van Buitenlandsche Zaken te hebben aangenomen; hij bedankte er dientengevolge voor. De wantrouwende Koning maakte hieruit op, dat Fagel achter het verzoek van George IV had gezeten om een "ambassadeur" te mogen behouden, en was

(a) „Le 11 mars 1823, le duc de Wellington faisait connaitre à lord Clancarty les plaintes du roi des Pays-Bas à son sujet: il ne pouvait plus tolérer que l'ambassadeur, se prévalant de ses anciennes relations, se comportât avec une liberté qui ne convenait point et tînt un langage peu mesuré. Cela marque de l'ingratitude, disait le duc, mais cela mérite votre attention. Lord Clancarty répondit qu'il croyait n'avoir jamais manqué de respect au roi Guillaume. Wellington trouvait cependant que, tout en ayant le bon droit de son côté, il aurait pu se montrer plus conciliant. Guillaume ne sut point oublier ses griefs et fit clairement entendre qu'il désirait le rappel de lord Clancarty. Celui-ci, sur le conseil du duc de Wellington, demanda enfin lui-même (octobre 1823) d'être relevé de ses fonctions. Il ne voulut aucune compensation et se retira de la vie politique. Guillaume, pour obtenir l'éloignement de son ancien ami, n'avait pas caché son intention de réduire l'an bassade des Pays-Bas à Londres en une simple légation, et cette menace avait forcé la main au roi d'Angleterre. George IV était lui-même intervenu près de lord Clancarty, afin de prévenir la transformation de l'ambassade, c'est-a-dire une mesure qu'il eût considérée comme une insulte." Juste bl. 58-59. - Zie Wellington's karakteristieken brief zelf en het antwoord daarop hierna in bijl. 20 getrokken uit dl. II (1867), bl. 65 en 68 van de „Despatches, Correspondence, and Memoranda of Field. Marshal Arthur Duke of Wellington, K. G." $0 p$ welken grond Juste's verhaal berust, dat Clancarty wegens de houding van onzen Koning zijn ontslag nam blijkt uit eene latere mede in bijl. 20 teruggegeven correspondentie van den ambassadeur met Wellington en George IV. 
hierover zóó verbolgen, dat hij hem uit 's lands dienst ontsloeg $(a)$ ! Hierdoor werd eene geheele wijziging in het ministerie noodzakelijk. Falck, de minister van Koloniën, werd bestemd tot Fagel's opvolger te Londen (b); Elout verliet Financiën dd. 30 Maart 1824 om de opengevallen plaats aan Koloniën in te nemen $(c) ; J$. A. Appelius kreeg Elout's portefeuille; Van Nagell's plaats werd, totdat men iemand zou vinden, tijdelijk vervuld door ridder $J$. G. Reinhold, onzen gezant te Rome en te Florence, die destijds in Nederland vertoefde, tengevolge van 's Konings gespannen verhouding met den Pauselijken Stoel $(d)$. Daar Reinhold echter van de koloniale zaken niets wist, en Koloniën tijdens Falck's afwezigheid geen hoofd had, gelastte de Koning, in overeenstemming met Reinhold's wenschen, dat de Londensche stukken, die weldra over de onderhandelingen zouden binnenkomen, aan Elout in handen werden gesteld.

Het was nu deze verwijdering uit de schoone Londensche positie, die Fagel geheel en al uit zijn evenwicht bracht en hem terstond aan Falck deed verklaren, dat hij zich buiten staat achtte aan de werkzaamheden voor de onderhandelingen behoorlijk deel te nemen. Een fraai begin dus $(e)$ !

Moest het reeds voor Falck onaangenaam zijn aldus uit Fagel's mond te vernemen, dat diens gemoedstoestand hem buiten staat stelde nog werk te verrichten, evenzeer zouden hem de mededeelingen treffen, dat Canning bij het hooren van de komst van den Nederlandschen gevolmachtigde zijne verwondering er over had

(a) Zie breeder in Fagel's Ontslag 404 vv.; ov. 12 vv.

(b) "Men zegt, dat de spotternijen van Falck den Koning hinderden en verlegen maakten; dat zijn onverholen af keuring van verderfelijke maatregelen hem kwetste; dat zijn voortrekken van bekwaamheid en talent boven titels en af komst ergernis gaf." Theod. Jorissen's Herinneringsrede over Falck (Amsterdam 1877), bl. 33. - Verg. Fagel's Ontslag 406-408, ov. 14-16.

(c) Zie hierover den brief in $B \ddot{j} d r . E .1851$ bl. 229.

(d) Men zie over Reinhold in Fagel's Ontslag 410; ov. 18. - „Les fonctions de ministre plénipotentiaire près du souverain pontife et du grand-due de Toscane étaient remplies par le chevalier Reinhold, d'abord démocrate allemand, puis officier au service de Louis Bonaparte, homme instruit (il avait traduit en vers allemands les sonnets de Pétrarque), mais joséphiste décidé, même philosophe un peu sceptique. Ce n'était pas lui qui pouvait être chargé de renouer fructueusement les négociations avec Rome pour la conclusion d'un concordat. Habilement supplanté par M. de Celles, il se retira à Florence, en attendant qu'il prit possession de la légation des Pays-Bas à Berne." Bl. 86 vv. Juste.

(e) Men zie verder over deze ontmoeting Fagel's Ontslag 408-410; ov. 16-18. 
te kennen gegeven, daar hij die in de bestaande omstandigheden niet verwachtte, terwijl ook de tweede Britsche gevolmachtigde, de heer $W y n n$, aan Fagel, volgens diens verhaal, had gezegd, dat men liefst niet de onderhandelingen had moeten beginnen! - Hoe gedrukt zich de ankomende onder die eerste ontmoeting gevoelde, blijkt uit een belangrijk particulier vertrouwelijk schrijven aan Van Nagell dd. 28 November 1823, dat deze nochtans als een officieelen brief deed agendeeren. Alleen werd door den schrijver nog de hoop gekoesterd, dat het verhaal over de min gunstige stemming der Britsche gevolmachtigden eenigszins op rekening viel te stellen van den bewogen gemoedstoestand van onzen ontslagen ambassadeur $(a)$.

Deze verwachting schijnt niet ongegrond te zijn gebleken; althans het nader officieel rapport dd. 2 December 1823 bevestigde geenszins de mededeeling, dat de Britsche ministers onwelwillend gezind waren.

Den $29^{\mathrm{n}}$ November werd Falck door onzen gezant aan Canning voorgesteld en "over deze korte, doch vriendelijke kennismaking" gevoelde gene "alle reden van voldaan te zijn". Men was, luidde de verzekering, van Engelsche zijde gereed om de onderhandelingen te hervatten; ook zou er, berichtte hij aan Buitenlandsche Zaken, vermoedelijk reeds eene voorbereidende conferentie op den $2^{n}$ December hebben plaats gehad, ware niet Canning verplicht geweest naar Portsmouth te vertrekken, alwaar zijne getuigenis voor een krijgsraad noodig was; maar dadelijk na 's ministers terugkomst beloofde hij Falck met den heer Wynn in betrekking te stellen.

Den $5^{\mathrm{n}}$ December kreeg onze mede-gevolmachtigde gelegenheid zijn geloofsbrief den koning van Engeland op Carlton House aan te bieden, terwijl hij den volgenden dag in Canning's kabinet $W_{y n n}$ ontmoette; doch met de karakteristieke onverschilligheid der Britsche staatslieden, die zoo dikwerf hindert, bleek het nu, dat nog niet eens het noodige was verricht voor de verstrekking van volmachten aan de twee Britsche onderhandelaars: origineele illustratie van Canning's vroegere verzekering, dat men gereed was te beginnen! Intusschen gaf men nu in Falck's tegenwoordigheid last om de ontbrekende stukken "zoodra mogelijk op te maken en den Koning ter teekening te doen toekomen". - Falck kon alzoo in zijn rapport van 9 December niet zeker zeggen, wanneer men werkelijk aan den arbeid zou gaan; doch dien dag zou hij een middagmaal op

(a) Zie bijl. 21. Ik haalde er reeds eenige zinsneden uit voor Fagel's Ontslag 409 ; ov 17. 
Gloucester Lodge bijwonen en daar dan vernemen, wanneer de eerste conferentie moest plaats hebben.

Van Nagell drukte, in zijn antwoord aan Falck op de rapporten van 2 en 9 December, het vertrouwen uit, dat dus spoedig de onderhandelingen zouden hervat worden $(a)$.

Het had weinig gescheeld, dat de op den maaltijd te Gloucester Lodge afgesproken datum tot samenkomst, namelijk 15 December, nieuw uitstel zou lijden, daar Canning den dag te voren weder door het podagra werd gekweld, zoodat hij het bed moest houden. Nochtans, ten einde het bewijs te geven van zijn ernstig verlangen . tot opening der werkzaamheden, deed hij onzen gevolmachtigden het voorstel, den $15^{\mathrm{n}}$ naar Gloucester Lodge over te komen en met hem te confereeren, in welken staat hij zich dan ook zou bevinden.

Overeenkomstig deze uitnoodiging werden de. onderhandelingen den $15^{\mathrm{n}}$ December 1823 geopend. Behalve de gevolmachtigden, kwam mede ter vergadering de secretaris van den Board of Control, de heer Courtenay.

De Nederlandsche onderhandelaars, 'wenschende de besprekingen op te vatten, waar men ze in 1820 had gelaten, moesten nu echter tot hunne verwondering vernemen, dat er heelemaal geen bericht van de Calcuttasche regeering was gekomen over de quaestie-Singapore, of liever dat zij zich bepaald had tot de mededeeling, dat de bezetting ervan wel en terecht was geschied! Van Britsche zijde wilde men nu van deze stelling uitgaan, doch hiertegen kwam men onzerzijds met kracht op, er o. a. aan herinnerende, dat Canning zelf indertijd het betoog van den gouv.-gen. Van der Capellen over het gepleegde onrecht allerbelangrijkst had verklaard.

De Britsche gevolmachtigden vingen toen aan met het bekende refrein van het Britsch belang in Singapore voor te brengen, waarom werd aangeboden deze plaats van ons te koopen. Zonder dit bepaald van de hand te wijzen, bracht men onzerzijds het hoofddoel der onder-

(a) "Met genoegen zag ik uit dezelven Uwer Excellentie's goede ontvangst bij en kennismaking met den heer Canning, mitsgaders UHEdG. receptie bij den Koning van Gr. Br. en vooral ook de verzekering, dat men aan de Engelsche zijde gereed is, om de onderhandelingen voor de O.-I. zaken wederom te beginnen.

${ }_{n} \mathrm{Ik}$ vertrouw, dat de eerste voorbereidende conferentie dien ten gevolge reeds zal hebben plaats gehad en mij schiet bij zoo gewenschte beginselen niets anders over dan hartelijk wenschen, dat Uwer Excellentie's volgende rapporten de welgegronde hoop zullen aanbrengen, dat de werkzaamheden met een gunstig gevolg zullen worden bekroond." (B. Z.) 
handelingen in herinnering, te weten door territoriale ruilingen afscheiding tusschen de bezittende machten tot stand te brengen. Daarvan scheen de wederpartij ook niet volstrekt afkeerig; doch aangezien ze hierover de bewindhebbers der Oost-Indische Compagnie wilde spreken, werd de samenkomst opgeheven. (a)

Toegezegd werd de volgende vergadering te doen plaats vinden, wanneer Canning hersteld zich naar Londen kon begeven. Om den tusschentijd inmiddels te benutten, zou men zich onledig houden met het nauwkeurig onderzoek der geldelijke geschilpunten, die bij den overgang der bezittingen in 1816 en 1817 onbeslist waren gebleven. Canning kon zich daarmede toch niet inlaten; en Fagel, ofschoon als de onderhandelaar van 1820 beter op de hoogte dan Falck, gevoelde er in de bestaande omstandigheden minder lust of geschiktheid toe, zoodat het werk zou worden verricht door Falck en Wynn (b). "Heeft men", besloot het Nederlandsch rapport dd. 16 December $1823 \mathrm{~N}^{\circ} 3$ aan Buitenlandsche Zaken (c), "zoo doende, eens zekerheid erlangd omtrent de vermindering of vermeerdering van de som, die bij de voorloopige verevening op Java, ten laste van Nederland gebleven is, dan zal men zich, in gelijker voege, dienen te verstaan nopens de waardij der voorregten, die wij als inhaerent aan onze bezittingen op de Vaste Kust van Indië beschouwen; en bedriegen wij ons niet ten aanzien der rigting, welke wij aldus in de gegeven omstandigheden voor de ons toebetrouwde onderhandelingen meest wenschelijk achten, zoo zal deze weg ook aan Uwe Excellentie als de meest geleidelijke voorkomen om het resultaat te bereiken, bij art. 4 der additionele punten van instructie bedoeld: - de mogelijkheid namelijk eener vergelijkende beoordeeling der voordeelen, hetzij territoriale, hetzij andere, die van Engeland bij de eventuele opoffering van onze regten wegens Sinkapoer zullen te bedingen zijn."

De samenkomsten, die alzoo tusschen Falck en Wynn over de financieele quaestiën plaats vonden, droegen echter gansch niet meer het vriendschappelijk, welwillend karakter, dat in 1820 de besprekingen had gekenmerkt; men achtte het dan ook noodig ze door schriftelijke behandeling te onderbreken. Het is wel mogelijk, dat sinds 1820 gewijzigde gedachten tot deze andere ver-

(a) Zie breeder in Singapore II $384-385$; ov. $72-73$.

(b) Eenigszins eigenaardig drukt Meinsma op bl. 177 dit aldus uit: „Tot vereffening van de finantiëele kwestiën werden Falck en Wynn afzonderlijk gekommitteerd."

(c) Opgenomen in noot 1, bl. XXVIII der inleiding Bijdr. $E$. 
houding aanleiding gaven, maar wellicht heeft de persoonlijkheid van den heer Wynn daartoe bijgedragen. De Engelsche geschiedschrijver noemt hem een poveren sire; zijne collega's in het kabinet raadpleegden hem niet en door niemand werd hij ontzien. Zulke gezaghebbenden zijn soms lastiger in zaken dan zij, die zich door hunne natuurlijke gaven van eene hooge, maatschappelijke positie verzekerd gevoelen. $(a)$

Een der eerste punten waarvan de Engelsche gevolmachtigde niet wilde weten, voert ons naar de op bl. 84 vermelde tijden van Daendels terug. Deze landvoogd, in geldverlegenheid zijnde, had de ingezetenen gedwongen hunne contanten af te staan, waartegen als zekerheid de in de magazijnen opgestapelde landsgoederen in pand waren gegeven. Toen nu de Engelschen zich van Batavia meester maakten, verklaarden zij deze voorraden voor goeden prijs, ten minste voor zoover niet aan den last van den gouv.-gen. Janssens om ze vóór de komst des vijands te verbranden, was voldaan. In die lastgeving ligt intusschen, zoo niet een bewijs, dan toch wel eene aanwijzing, dat zelfs ons eigen bestuur van het onschendbare dier zekerheid niet diep overtuigd was. Het komt mij dan ook wel vreemd voor, dat Commissarissen-Generaal indertijd van Fendall, den Britschen landvoogd te Batavia, de som van 2.410.655 rijksdaalders wegens dit punt hadden gevorderd. De eisch scheen zóó weinig gegrond, dat reeds bij de onderhandelingen van 1820 de vraag: "Le Gouvernement des Pays-Bas a-t-il droit de réclamer la valeur des produits coloniaux et autres objets hypothéqués spécialement aux créanciers de l'État, mais capturés par les agents de prise" niet alleen van Engelsche zijde ontkennend was beantwoord, doch de toenmalige gevolmachtigden Fagel en Elout er reeds destijds van afzagen, door in art. 9 van hun ontwerp dd. 24. Juli 1820 de bepaling op te nemen: "Le Gouvernement des Pays-Bas renonce à la réclamation faite pour la restitution de

(a) Onder het jaur 1828 leest men in Walpole II 468: „Poor Charles Wynn had, for more than five years, discharged the duties of the India Board. During that period he had been consulted by few of his colleagues and feared by none of them. He had been regarded as the representative of the Duke of Buckingham, and submitted to, in consequence, as an inevitable evil. Unfortunately for Wynn, some difference arose between his noble relative and himself. The duke, who was insatiable in his demands for high office, thought that Wynn stood in his way. An estrangement ensued between the two, of which the Duke of Wellington was perfectly aware. Wynn, in consequence, found himself left out in the cold, and was dismissed from the India Board with very little ceremony." 
la valeur des objets, qui se sont trouvés dans les magasins au moment de la conquête en 1810 , mais qui étoient spécialement hypothéqués aux créanciers de l'État" $(a)$.

Het is niet duidelijk, waarom Falck dan toch dit punt ter sprake bracht; ik denk, wijl hij, evenals ten aanzien van de op bl. 128 vermelde quaestie over de differentieele rechten, eerst ter elfder ure met de geschiedenis der zaak bekend werd $(b)$.

Wat betrof onze aanspraak op vergoeding voor waarden van verschillende soort, bij den overgang der kolonie aan het Britsch gezag in de koloniale kassen gevonden, van Engelsche zijde werd er tegen aangevoerd, dat dit alles jure belli, ten profijte der veroveraars gekomen was; onze gevolmachtigden moesten toegeven, dat dit "niet zonder reden" werd aangevoerd. Zoo zij hierin werkelijk gelijk hadden, is het dan toch te betreuren, dat Commissarissen-Generaal indertijd al dergelijke vorderingen deden, waardoor zij slechts den onwil van Fendall in Rade konden opwekken en opwekten. - Dezerzijds bleef men voorloopig weigeren als schuld te erkennen, hetgeen de luitenant-gouverneur Raffles had betaald voor het terugkoopen van Probolinggo en Besoeki, zoomede wat voor de intrekking van het Bataviaasch Credietpapier was gestort. Evenmin kon men tot overeenstemming komen over de waarde van de door Commissarissen-Generaal overgenomen artillerie-behoeften. De Engelschen hadden er driemaal meer voor gevraagd dan Commissarissen er destijds voor wilden geven. Instede van toenmaals ò de overneming te weigeren, òf zich onverwijld te verstaan, verwees men de zaak naar eene beslissing in Europa, waar men zich natuurlijk geheel en al buiten staat gevoelde het overgenomene billijk te schatten; doch in de militante verhouding, die tusschen Elout c. s. en Fendall in Rade ontstaan was, zag men ten slotte geen anderen uitweg dan een beroep op Europa. "Grootelijks is het te bejammeren", schreven Fagel en Falck naar Holland, "dat men in Indië niet gebleven is bij het aanvankelijke plan om de waardeering gemeen-

(a) Zie Bïjdr. E. 101, 105, 112, 117. - Er staat op bl. 117 het jaartal 1810 , doch bedoeld zal zijn, denk ik, 1811.

(b) In hun belangrijk rapport over de financieele geschilpunten van 26 December 1823, opgenomen in Falck's Ambtsbrieven bl. 180-185, schreven beide gevolmachtigden aan Buitenlandsche Zaken over het afzien van de in den tekst beschreven vordering (bl. 181): "Trouwens wij herinneren ons, en het blijkt uit de minuut eener overeenkomst in 1820 als leiddraad der toenmalige conferentiën ontworpen, dat men reeds te dier tijd geene hoop meer voedde om de onderhavige pretentie erkend te krijgen." 
schappelijk te doen" (a). Eindelijk konden Falck en Wynn het niet eens worden over de waardeering der voordeelen, verbonden aan de rechten, die tot 1795 aan onze bezittingen in Vóór-Indië behoorden (b).

Bij zooveel verschil van gevoelen scheen eene algemeene conferentie over de financieele punten noodzakelijk; doch Canning lag nog altijd te Gloucester Lodge ziek, zoodat men wel verplicht was andermaal derwaarts te gaan, wilden de naderende kerstmisdagen niet in het midden dezer werkzaamheden storend vallen, als wanneer gedurende twee weken de zaken geheel stil stonden. Dientengevolge togen de drie gevolmachtigden den $25^{\mathrm{n}}$ opnieuw naar Canning's verblijf. Van Engelsche zijde liet men toen vallen den eisch tot vergoeding van het Bataviaasch Credietpapier, doch de vordering betreffende Probolinggo en Besoeki bleef men handhaven. Van onze zijde werd voor den afstand der bezittingen in Vóór-Indië gevorderd 312.000 pd. st., waarvan echter de Britsche heeren niets wilden weten $(c)$.

Evenmin toonden ze een geopend oor te hebben voor eene ruiling van Benkoelen versus factorijen in Vór-Indie; wel echter, schreven onze onderhandelaars dd. 26 December aan Buitenlandsche Zaken, voor eene ruiling van Benkoelen tegen Malakka met Singapore, wat de Nederlandsche vertegenwoordigers zeer veel genoegen veroorzaakte, rapporteerden ze, terwijl ze dan nog op den koop toe de erkenning van ons recht op Billiton zouden krijgen $(d)$ !

Eindelijk stelden de Britsche onderhandelaars voor om alle geldelijke quaestiën met de vergoeding voor onzen afstand van de factorijen in Vóŕ-Indië uit te maken door van onze zijde eene som van 100.000 pd. st. te betalen vóór het einde van 1824: dit was, betuigden zij ernstig en bij herhaling, het uiterste waartoe zij konden gaan "zonder zich ten hoogste verantwoordelijk te maken". Onze gevolmachtigden hielden zich nu echter goed; zij verklaarden even ernstig, dat aan geene betaling van welken aard kon gedacht worden; ook weigerden zij den aandrang gevolg te geven van er althans de Nederlandsche regeering over te schrijven.

Zoo bleven de zaken eenige dagen hangende en schenen de onderhandelingen alweder afgebroken te zullen worden, toen Falck een briefje van Wynn ontving, houdende mededeeling, dat Canning

(a) Zie Elout $240-241$; ov. 12-13.

(b) Zie hierover in bijzonderheden Factorijen II 463-464; ov. 179-180.

(c) Zie hierover in het breede Factorijen II 464-467; ov. 180-183.

(d) Zie de woorden van het rapport van 26 December in Singapore II $385-386$; ov. $73-74$. 
de heeren alsnog wenschte te spreken $(a)$. Hieraan werd natuurlijk gevolg gegeven.

Had op de bijeenkomst van 15 December de tegenpartij voorgesteld Singapore te koopen, zij verklaarde zich nu bereid den koop te sluiten door de vordering van 100.000 pd. st. kwijt te schelden. Doch ook daarmee konden zich de Nederlandsche onderhandelaren niet vereenigen, aangezien o. a. ruiling wél, betaling niet naar buiten werkte, terwijl dit toch voor ons prestige in den Archipel, na al het gebeurde, wenschelijk was. Overigens meenden zij ook nu, dat we met den afstand van Malakka met Singapore niets hadden te verliezen, daarentegen met de verkrijging van Benkoelen en de verdere Britsche factorijen op Sumatra veel zouden winnen, door de eenheid van gezag, die aldus zou kunnen ontstaan (b).

Zoo bleef dus de vordering van 100.000 pd. st. het struikelblok; de Britsche gevolmachtigden deden daarop de vraag of er niet eenige voordeelen aan de Engelsche scheepvaart en den handel in Oost-Indië door ons konden toegezegd worden, die als eene schadeloosstelling voor de geldsom viel te beschouwen. Hierover zou, antwoordde men onzerzijds, gedacht worden, waarop de vergadering uit elkander ging $(c)$.

(a) Private

Whitehall Place, Tuesday.

My dear Sir,

Mr. Canning will be happy to see you and Baron Fagel at a conference to morrow at three; but I much fear that if your instructions preclude you from agreeing to any payment, whatever the balance due to us may be, it is scarcely possible that we can bring our present negotiation to a favorable termination. At all events the proposition for transforming us from creditors into debtors and transferring the balance due in one side of the account to the other as contained in the article of your projet, cannot even bear discussion. - Believe me, dear Sir, with the highest regard and esteem ever most faithfully yours

\section{Mr. FALCK}

Ch. William Wyns.

$$
\text { c. c. c. (B. Z.) }
$$

(b) Zie veel breeder met beoordeeling Singapore II 387-389; ov. 74-77.

(c) Over de territoriale quaestiën rapporteerden onze gevolmachtigden breedvoerig dd. 12 Januari $1824 \mathrm{~N}^{\circ} 5$, afgedrukt in Bijdr. E. 173-178; over de geldelijke geschillen den $27^{\text {n }}$ d. a. v., welke mede zeer belangrijke depêche is afgedrukt in Singapore II bijl. 9. Wel is deze depêche van 27 Januari in zeker opzicht, „van voorbijgaand belang”, gelijk de bezorger der Elout-bijdragen op bl. XXVIII schrijft, maar voor eene volledige kennis der geschiedenis van het tractaat van 1824 moet men haar onder bereik hebben. Instede daarvan gaf men in de Elout-bijdragen op bl. 187 wel een briefje weder van minister a. i. Reinhold aan Elout, waarin over die depêche "van voorbijgaand belang" advies wordt gevraagd! 


\section{XIII.}

\section{De voorstellen onzer gevolmachtigden in minister Elout's handen op het einde van Januari 1824.}

Onze gevolmachtigden hadden over de territoriale ruiling Malakka met Singapore tegen Benkoelen, benevens de erkenning van Nederlands recht op Billiton bij het rapport dd. 12 Januari 1824 's Konings welmeenen gevraagd, daar aldus veel minder te verkrijgen zou zijn dan hunne instructioneele voorschriften inhielden $(a)$. De Nederlandsche kantoren in Hindostan waren buiten dit voorstel gebleven, omdat, stond er in het schrijven, de Engelschen er weinig voor over toonden te hebben (b). Het rapport van 19 Januari is uitsluitend aan de behandeling van dit onderwerp gewijd geworden; er werd daarin aangetoond, dat die factorijen slechts lastposten waren $(c)$. Met dit stuk hield vervolgens nauw verband de belangrijke brief van 27 Januari $(d)$, waarin tevens alle financieele geschilpunten werden behandeld. Het stuk kwam hierop neder, dat Engeland genoegen zou nemen met eene vordering op ons van 100.000 pd. st., mits wij dan ook onze bezittingen in Vóór-Indie prijsgaven en onze schuld vóór het einde van 1824 betaalden (e). Echter zoude die som van f 1.200 .000 ons kwijtgescholden worden, wanneer de Nederlandsche gevolmachtigden in staat waren, ten genoegen van Engeland eenige handelsvoordeelen aan te bieden; van welken aard die konden zijn, zouden onze gevolmachtigden nader overwegen. Ter verdediging van de honderdduizend pond sterling werd door onze gevolmachtigden er op gewezen, dat Commissarissen-Generaal bij de conventie van 24 Juni 1817 de wettigheid der Engelsche vorderingen erkend hadden tot het aanzienlijk bedrag van 1.817.183 ropijen; wat van Engelsche zijde daar boven was gevorderd, namelijk "meest al de vorderingen in de Kolonie zelve in het midden gebragt", deden onze gemachtigden verwerpen; doch ook — rapporteerden zij tevens - had "eene menigte" der tegenvorderingen van Commissarissen-Generaal, waardoor niet alleen de Engelsche vordering zou zijn gedelgd, maar wij een millioen te vorderen

(a) Zie Singapore II 389; ov. 77.

(b) Zie uitvoeriger in Factorïen II 464; ov. 180.

(c) Factorïjen II 465-467; ov. 181-183.

(d) Vermeld op bl. 139 noot c.

(e) Factorïen II 467-468; ov. 183-184. 
kregen! "den toets eener bedaarde en opregte discussie", naar Fagel's en Falck's oordeel, niet kunnen weerstaan, zoodat men eindelijk op het doode punt van 100.000 pd. st. was gebleven.

Men moest het nu maar in Holland uitmaken. De minister a.i. van Koloniën, de heer Reinhold, niet op de hoogte der zaken zijnde, gelijk hiervoren medegedeeld, wendde zich met 's Konings voorkennis en goedkeuring, tot den minister van Financiën Elout met vriendelijke verzoeken, om in de koloniale aangelegenheden van advies te dienen. Deze manier van behandeling had eene ernstige schaduwzijde. Elout stond officieel buiten de onderhandelingen en was met zware werkzaamheden voor zijn eigen departement belast; bovendien moetende voldoen an den eisch eener spoedige behandeling, gaf hijzelf te kennen, dat zijne adviezen slechts vluchtig konden zijn. Ook was hem, door de zonderlinge wijze, waarop de Koning met zijne ministers omging, onbekend gebleven, dat Canning reeds vóór den aanvang der onderhandelingen den wenk had gekregen over onze bereidwilligheid tot den afstand van Singapore $(a)$; natuurlijk dat hem de Londensche rapporten niet medevielen. Men zou het haast niet gelooven, wanneer het niet zoo uitdrukkelijk verklaard is geworden, namelijk dat minister Elout bij zijne beoordeeling over de verschillende voorstellen der onderhandelaars, geene kennis had ontvangen noch van de additioneele instructie, noch van de missiven, die aan de voorstellen waren voorafgegaan! "Uwe ambtsbezigheden", schreef Falck, ontevreden over Elout's aanmerkingen, in een nader te noemen brief dd. 2 Februari 1824, "lieten $\mathrm{u}$ inderdaad niet toe in eene grondige beoordeeling te treden; maar ten minste had men $u$ onze vroegere dépêches en onze additionele instructie behooren mede te deelen" (b). - - Er was nog een kwetsend punt in deze behandeling. Geen verstandig man in den staatsdienst, al is hij ook zóó bekwaam en al is hij nog zóó tevreden met zijn arbeid, zal zich in beginsel ontstemd gevoelen over het advies, dat de meerdere aan derden vraagt, alvorens tot eene beslissing te komen; integendeel, hij zal dit toejuichen, in de overtuiging, dat er alzoo meer waarborgen bestaan tegen het naar buiten werken van fouten; doch die adviseurs moeten dan ook als wettig aangewezen kunnen beschouwd worden; het moeten persoonlijkheden zijn, waarmede men voor den dag kan treden; geene anonieme stukken dus, die

(a) Singapore II 380-383; ov. $68-71$.

(b) Falck's Brieven 258. 
van Jan en alleman kunnen uitgaan, waarvoor de meerdere zich niet eens verantwoordelijk wil stellen en ook niet kan stellen, omdat hij volstrekt niet op de hoogte der zaak is! Wij kennen deze treurige wijze van doen uit Indië; zij werd ook hier in toepassing gebracht, en Falck, noch Fagel was er de man naar, om zich zulk eene behandeling zonder protest te laten welgevallen.

Het rapport van 12 Januari over de territoriale ruilingen was den $18^{\text {n }}$ te 's-Gravenhage ontvangen. Op 's Konings last had er den volgenden dag aan het departement van Financiën eene samenkomst plaats tusschen Elout en Reinhold; het gevolg was eene nota, gedagteekend 20 Januari, waarin Elout het gesprokene op schrift stelde. Het stuk valt in zoover tegen, dat de minister nu geen overwegend bezwaar meer tegen het verlies van Malakka en Singapore maakte; we zouden er toch niet aan hebben, meende Rapporteur. Benkoelen - dat wij ons niet moeten voorstellen, gelijk het nu is, doch als eene factorij, gelijk het ook officieel heette - oordeelde hij echter terecht eene magere ruiling $(a)$. Wanneer het verder op ruiling van grondgebied aankwam, dan moest alles bij elkander genomen worden, merkte de minister verder zeer juist op, en alzoo diende men onze factorijen in Vóór-Indië er niet buiten te laten; de Engelschen mochten beweren, dat ze er niets aan hadden, dat waren echter maar praatjes (b). Eindelijk erkende hij, dat het een op zichzelf zeer aannemelijk denkbeeld was om eene scheiding te maken tusschen de Nederlandsche en Britsche bezittingen; maar men diende ze goed te omschrijven, en dan nog was het de vraag, of ze van Engelsche zijde ten slotte geëerbiedigd zou worden. "Men denke bijvoorbeeld aan Borneo", voegde de minister er met profetischen blik aan toe.

Hij had er bovendien, niet zonder eenige reden, bezwaar tegen, dat aldus de territoriale ruilingen door gevolmachtigden waren behandeld buiten de geldelijke quaestiën, en in het algemeen, dat hij geroepen werd op het eenzijdige stuk van 12 Januari te adviseeren. Er werd aan deze moeilijkheid te meer door hem gehecht, omdat hij nog in de illusie verkeerde, dat van de opgedreven vorderingen der Commissarissen-Generaal iets terecht zou komen. "Het zal voorts moeijelijk zijn", besloot de Nota, "om over alle, en over elk der geschilpunten een juist oordeel te hebben, tenzij

(a) Zie breeder in Singapore II 389-390; ov. 77-78.

(b) Zie breeder in Factorijen II 468-469; ov. 184-185. 
men den geheelen zamenhang der zaken en den geheelen inhoud van eene te ontwerpen overeenkomst zie en overwege, en het is de huivering om over een gedeelte te oordeelen zonder het geheel te kennen, die dit een en ander uit de pen heeft doen vloeijen." Hij wilde dan ook slechts zijne beschouwingen opgenomen zien als het resultaat van "eene voorloopige overdenking van dit gewigtig onderwerp". "De tijd is te kort", voegde de minister er aan toe, " om alles te ontwikkelen, en welligt is de niet bekendheid met latere berigten oorzaak, dat men zich in de beschouwingen bedriegt." Blijkbaar was echter Elout teleurgesteld; hij vond, dat de gevolmachtigden, wien een leidend beginsel ontbrak, een beetje broddelwerk leverden, en zoo merkte hij nog verzachtend op: "Deze vlugtige bedenkingen moeten niet beschouwd worden van de strekking te hebben om de denkbeelden door de Nederlandsche Gevolmagtigden geopperd, af te keuren, maar alleen om eenige wenken te geven, die bij gelegenheid der onderhandelingen hare nuttigheid hebben kunnen."

Elout zond de nota van den $20^{\mathrm{n}}$ denzelfden dag met een briefje aan Reinhold (a). Hij verzocht de in het stuk wedergegeven "vlugtige gedachten" enkel als zoodanig aan de heeren Fagel en Falck mede te deelen en daarbij aan die heeren te schrijven : "dat over het algemeen eene ruiling van grondgebied tegen grondgebied wel aannemelijk kan geacht worden, maar dat daarbij niet uit het oog moet worden verloren, maar wel in verband gebragt ook andere ruilingen en vooral ook geldelijke tegemoetkomingen en schadevergoeding van geldelijke voordeelen".

Geheel overeenkomstig dit voorstel werd dd. 22 Januari, op 's Konings last, een brief aan onze onderhandelaars door Buitenlandsche Zaken gezonden, bevattende de aangehaalde woorden $(b)$. Elout's nota werd anoniem overgelegd, terwijl ook de ministerieele depêche niet mededeelde, van wien de beschouwingen waren. De brief was overigens welwillend genoeg gesteld. 's Konings vertrouwen op de "omzigtigheid en kennis van zaken" der gevolmachtigden

(a) In Bïdr. E. 178. - De eerste alinea van Elout's Nota zou volgens Bïdr. E. 179 luiden: „Het schijnt eenigzins moeijelijk om het onderwerp van den brief door de Heeren Fagel en Falck, op 12 December, $n^{\circ} 8$, geschreven, op zich zelven te behandelen." Het door mij gespatieerde is echter eene fantaisie van den bezorger der Bijdragen en, ook in verband met andere stukken, eene zeer storende datumfout. In het oorspronkelijke stuk staat „op 12 dezer $N^{\circ} 5$ geschreven." Dat dezer is Januari.

(b) Zie den brief in bijl. 22. 
werd er ook in uitgedrukt; doch de Nota deed aan het geloof op dit vertrouwen meer kwaad, dan de betuiging kon goedmaken. Trouwens, zoo het wellicht van de onderhandelaars niet juist gezien was, reeds eene beslissing te vragen op hun brief van 12 Januari, het mag evenmin van de Regeering als eene gelukkige gedachte beschouwd worden, zou men zeggen, dien brief anders te hebben beantwoord dan met eene algemeene mededeeling, omtrent 's Konings verlangen, dat de zaken in haar geheel zouden voorgebracht worden. $\mathrm{Nu}$ kreeg men slechts eene correspondentie, die men juist had willen vermijden.

Reeds twee dagen namelijk na de afzending der's-Gravenhaagsche depêche van den $22^{\mathrm{n}}$, ontving Buitenlandsche Zaken den Londenschen brief dd. 19 Januari over de factorijen in Hindostan. Het stuk ging weder op 's Konings last naar Elout $(a)$. Deze diende er op bij Nota van 26 Januari $(b)$. Hij herhaalde daarin zijne rechtmatige klacht, dat op die wijze de zaak niet voor eene afdoende behandeling vatbaar was; zoo "heeft men op nieuw de moeijelijkheid ondervonden", merkte hij toch op, "van op elk punt afzonderlijk een bepaald gevoelen te vestigen"; en hij drong verder met kracht aan, dat voor den afstand der Factorijen, eene behoorlijke som wierd gevorderd $(c)$. Ook deze Nota werd anoniem bij depêche van Buitenlandsche Zaken dd. 27 Januari naar Londen ter speculatie gezonden $(d)$.

Stormweer was oorzaak, dat de Haagsche brief van den $22^{\mathrm{n}}$ Januari eerst den $30^{\mathrm{n}}$ d. a. v. en die van 27 Januari den $2^{\mathrm{n}}$ Februari hunne bestemming bereikten, zoodat nog vóór de aankomst dezer stukken, onze gevolmachtigden, onafhankelijk hiervan, mede hadden doen afgaan hunne depêche van 27 Januari, waarin zij handelden over de geldelijke geschillen, speciaal mededeelende, dat Engeland verlangde $100.000 \mathrm{pd}$. st. of Handelsvoordeelen, waarover onze onderhandelaars nog beloofden te denken $(e)$. Andermaal richtte Reinhold op 's Konings last een "vriendelijk verzoek" dd. 31 Januari aan Elout om advies $(f)$; maar nu antwoordde deze dan toch enkel, dat men vóór hij zijn oordeel uitsprak, beter zou doen eerst te wachten op

(a) Zie Reinhold's briefje dd. 24 Januari aan Elout in Bijdr. E. 182.

(b) In Bïdr. E. 185-187.

(c) Zie de woorden in Factorijen II 469-471; ov. 185-187.

(d) Zie de depêche in bijl. 23.

(e) De belangrijke depêche van 27 Januari 1824 in bijl. 9 Factorïen II.

(f) In $B \ddot{y} d r . E$. 187. 
het nader rapport onzer gevolmachtigden over de Handelsvoordeelen toetekennen voor de 100.000 pd. st. $(a)$.

Reinhold kon zich hiermede natuurlijk vereenigen, doch ten einde de onderhandelaars niet geheel zonder bericht te laten, werd door hem, op 's Konings machtiging, dd. 3 Februari naar Londen geschreven $(b)$, datgene, wat men reeds bij ontvangst der depêche van 12 Januari had moeten doen, namelijk dat het rapport "geen dadelijk of stellig bepaald antwoord" kon ten gevolge hebben, zoolang men niet de nader toegezegde mededeeling had over den aard der handelsvoordeelen, die door onze gevolmachtigden, of liever door Falck als minister van Koloniën, zouden worden aangegeven. Overigens ontbrak ook hier niet de welwillende betuiging namens den Koning : "dat Uwe Excellentiën de vorderingen, die tegen die van Engeland kunnen worden overgebragt, met zorg behandeld hebben".

Dit waren nu de staatslieden, die als plaats van samenkomst Londen hadden verkozen boven 's-Gravenhage!

\section{XIV.}

\section{Kapitein Elout met de ontwerp-overeenkomst van 1 Februari 1824 van Londen naar 's-Gravenhage.}

Gelijk minister Elout zich terecht beklaagd had, was tot dusver door de gevolmachtigden nog geen stuk aangeboden, dat in zijn geheel als grondslag voor een tractaat kon worden beschouwd en dus een artikelsgewijs gesteld overzicht gaf van het voorloopig resultaat der onderhandelingen. Aan dit bezwaar kwamen partijen nu tegemoet. Terwijl namelijk de Nederlandsche onderhandelaars op antwoord

(a) „Ik ben zeer bereid mijne gedachten over de depèche der Nederlandsche gemagtigden te Londen van 27 Januarij $\mathrm{N}^{\circ} 13$ mede te deelen, maar eigenlijk vereischt (onder beter oordeel) dit stuk geen dadelijk of stellig antwoord. Veel beter zal alles kunnen beoordeeld worden, wanneer wij het gevoelen van den heer Falck zullen kennen over de voorregten, welke in stede van de geldsom zouden kunnen worden toegestaan.

„Ik neem de vrijheid dit aan den heer Reinhold te onderwerpen en heb voorts de eer te zijn

3 Febr. 1824.

UwDw.Dr. Elout."

De bezorger der Elout-bïdragen, met dit incident blijkbaar onbekend, stelt op bl. 188 over het door Reinhold aan Elout verzocht rapport de aanteekening: "Het hierbij bedoelde rapport, betrekkelijk de verevening van geldelijke punten, schijnt tusschen den Minister Elout en Reinhold mondeling te zijn behandeld."

(b) Zie Bijdr. E. 188.

$7^{\circ}$ Volgr. II. 
hunner Regeering wachtten, stelden partijen een ontwerp-tractaat samen, waarmede over en weer genoegen werd genomen. Dit gewichtige stuk is de grondslag van de in Maart 1824 te sluiten overeenkomst geweest. Redactie en inhoud zouden wel min of meer belangrijke veranderingen ondergaan, doch, behoudens drie artikelen, die wegvielen, bleven grondgedachte en volgorde der bepalingen bestaan. Het komt mij echter gewenschter voor, het ontwerp in zijn geheel voorloopig te laten rusten en eerst dan een overzicht van de artikelen enz. te geven, nadat de lezer bekend is gesteld met hetgeen onze gevolmachtigden over het ontwerp in het algemeen mededeelden en op welke wijze het in Nederland werd behandeld.

Wij zullen ons herinneren, dat Falck zich sterk had gemaakt om eenige door ons aan Engeland toe te kennen handelsvoordeelen te bedenken, waarvoor de wederpartij hare vordering van 100.000 pd. st. beloofde los te laten. Blijkens het ontwerp zouden die nu bestaan in de verzekering onzerzijds der vriendelijke ontvangst (sic) van de Britsche schepen te Anjer en Tapanoeli, zoomede in eene jaarlijksche levering door ons van vastgestelde hoeveelheden specerijen tegen overeengekomen prijzen $(a)$. Dit waren de nieuwe punten in het ontwerp, welke bij depêche van 1 Februari 1824 Buitenlandsche Zakien werden aangeboden $(b)$. Teleurstellend luidde het er in, dat Rapporteurs zich door 's Konings goedkeuring op hunne voorstellen "meer gesterkt". gevoelden, "dan door de aanmerkingen der ons toegezonden nota ontmoedigd"! Dringend bevalen zij dan ook de goedkeuring van hun ontwerp aan. "Niet alsof wij de wenschelijkheid miskennen, dat voor Nederland nog meerdere voordeelen hadden kunnen bedongen worden, maar wij zijn in gemoede overtuigd, dat de zwarigheden van welke zulks, blijkens onze verschillende rapporten, vergezeld ging, noch door herhaling onzer dringende vertoogen, noch door eenige andere middelen onder ons bereik, hadden kunnen worden overwonnen." Zoo drukte de gansche toon van den brief gevoeligheid over de gemaakte aanmerkingen uit. "Dat verder", besloot de depêche, onder mededeeling, dat zij te vergeefs moeite hadden gedaan om de voor ons zoo nadeelige waardeering der artillerie-goederen voor eene afzonderlijke behandeling te bewaren, "Dat verder aanhoudende reclamatiën, hetzij in dit opzigt, hetzij in eenig ander, tot het gewenschte doel zouden voeren,

(a) Zie Atjeh 194; ov. 36.

(b) In Bijdr. E. 191. 
voor zoover dit doel is de nitkeering aan Nederland van eene noemenswaardige somme gelds, nemen wij de vrijheid van ten sterkste te betwijfelen. Maar al bestond ten deze eenige kans in ons voordeel, de tijd, die inmiddels verloopen moet, zoude waarschijnlijk andere kansen aanbrengen, waarover wij ons geenzins zonden verheugen kunnen. Onder dit aspect komen in anmerking de onzekerheid of het Engelsche ministerie nog wel zoo veel prijs op de afdoening der onderwerpelijke zaken zal blijven stellen, wanneer andere belangen, tot de Europesche of Amerikaansche staatkunde betrekkelijk, deszelfs aandacht meer gebiedend mogten roepen; de mogelijkheid, dat de Oost-Indische Compagnie eenen magtigen steun in de volksmeening zal vinden, zoodra het plan, om Benkoelen door haar te doen afstaan, eenige ruchtbaarheid zal hebben verkregen; de bewegingen eindelijk van allerlei aard, welke men van den heer Raffles voorzien kan, dadelijk nadat hij in de ophanden zijnde lente te Londen zal zijn aangekomen."

Met Malakka zou nu ook Singapore verloren gaan; en speciaal om dit punt zoo noodig toe te lichten, werd kapitein Elout opgedragen de ontwerp-overeenkomst naar Nederland te brengen. "Het is vooral", leest men in de depêche, "uit besef der teederheid van deze materie en van het verlangen, welk Z. M. misschien hebben zal om deswege nog meer ontwikkelingen te hooren dan het gemakkelijk is in geschrifte te suppediteren, dat wij besloten hebben het overbrengen der tegenwoordige depêche en van de daartoe behoorende stukken op te dragen aan den kapitein Elout, die zoo zeer als iemand met de kennis van plaatsen, personen en betrekkingen in den Maleischen archipel toegerust is. Hoe meer wij ons te loueren hebben over de diensten, welke deze ijverige en oordeelkundige ambtenaar ons in den loop onzer negociatie bewezen heeft, hoe meer wij vertrouwen, dat UHoogEdG. $(a)$ en eventueel ook Z. M. hem ten eenemale berekend zullen vinden, om al dic bijzonderheden en al dat licht te verschaffen, welke tot eene juiste beschouwing 'van vele ingewikkelde kwestien en tot de behoorlijke kennis van het verband, welke tusschen dezelve bestaat', vereischt worden."

Tegelijkertijd schreef Falck als minister van het Publiek onderwijs de Nationale nijverheid en de Koloniën eene depêche aan den Koning (b). Hij behandelde er speciaal in de bij het ontwerp ge-

(a) Reinhold als minister a. i. was niet eene Excellentie.

(b) Reeds vermeld op bl. 128 noot $a$. 
regelde tarievenquaestie en de daarin voorkomende bepaling omtrent den specerijhandel, waarna hij aldus besloot: "Uwe Majesteit zal misschien niet zeer genegen zijn om te gelooven, dat de Minister van Koloniën een werk, waaraan hij zooveel deel heeft als aan dat der Plenipotentiarissen te Londen, met genoegzame onpartijdigheid beoordeelen kan. Ik zal mij dus, wat de adstructie en aanbeveling des ontwerps betreft, eenvoudig gedragen aan de dépêche, waarbij hetzelve aan het Departement van Buitenlandsche Zaken wordt ingezonden; maar dit achte ik mij echter in mijne eerstgenoemde kwaliteit verpligt van te verklaren, dat het Indisch bestuur en al wie de ware belangen van Uwer Majesteits bezittingen kennen, met genoegen eene schikking vernemen zouden, waardoor een aantal lastposten vervallen, de vreemdeling uit de nabuurschap der hoofdplaats verwijderd wordt, eene zuivering der wederzijdsche limieten plaats vindt en er een einde komt aan langdurige onzekerheid."

Bovendien schreef Falck een particulieren brief, gedagteekend 2 Februari aan minister Elout. Ook daaruit blijkt de gevoeligheid over de gemaakte opmerkingen $(a)$. Niet alles zegt hij bovendien, daar hij overigens wenscht te verwijzen "aan hetgeen brenger dezes u zal zeggen". Ook is de toon nog eenigszins verzacht, doordien minister Elout zelf de voorzorg had genomen, om tijdig onze gevolmachtigden over het ontstaan der nota's in te lichten, waarover Falck zich "uitermate verpligt" verklaarde. "Immers", vervolgde de brief, "ik vond daarin het oogpunt aangewezen uit welk de vlugtige aanmerkingen moesten worden beschouwd, die gij $\mathrm{u}$ niet hadt kunnen onthouden van te suppediteren; en zulks is voor mij genoeg geweest om het denkbeeld eener officiele wederlegging te verwerpen". Hij herinnert er verder aan, dat van de Engelschen geen geld is los te krijgen, dat zij geene andere bezitting voor afstand kunnen aanbieden dan Benkoelen en dat Malakka een lastpost voor ons is (b). "Doch", valt hij zich in de rede, "ongemerkt empiëteer ik op de taak van kapt. Elout, die in een paar gesprekken meer nuttige ophelderingen kan geven, dan wij in tien dépêches." Zoo, meende Falck, zou de klacht van minister Elout over gemis aan toelichting bevredigd worden. "Aan het gebrek aan bescheiden", schreef hij nog, "wordt nu te gemoet gekomen door de tegenwoordigheid van uw zoon, die alles in zijn hoofd

(a) Afgedrukt in Falck's Brieven 258.

(b) Zie Singapore II 390-391; ov. 78-79. 
heeft, en, ten overvloede, den bundel rekeningen van Bauer c. s. medeneemt, of men bij geval ook nog verkiezen mogt de details daarvan op te schommelen. Ik heb mij niet bedrogen in mijne gedachten omtrent het nut, dat uw zoon ons hier zoude aanbrengen. Van zijne plaatselijke kennis niet alleen, maar ook van zijne schranderheid in het beoordeelen van delicate vraagpunten hebben wij dikwijls partij getrokken. Meer dan één artikel van het project-tractaat is daaraan deszelfs rondheid en zuiverheid verschuldigd. Hij denkt nevens mij, dat zoodanig een tractaat in O. I. bij de verstandige lieden welkom wezen zal. Beschouw het, bid ik $\mathrm{u}$, in deszelfs ensemble."

Verstandige lieden! Zoo pleegt men in betwistbare zaken aanstonds andere beoordeelaars vóór te zijn; dezen weten dan, waaraan zij zich in de waardeering hunner wederpartij, bij afwijkend oordeel, hebben te houden.

\section{XV. \\ Bezwaren in Nederland tegen het ontwerp-tractaat: medio Februari 1824.}

Kapitein Elout was den $5^{\text {en }}$ Februari te 's-Gravenhage aangekomen. Hij had onze gevolmachtigden vol verwachtingen over het gereed gemaakte tractaat achter gelaten. Ze werden in hunne gunstige stemming versterkt door een schrijven van den heer Reinhold dd. 6 Februari, waarop wordt teruggekomen. Zoo rees bij de Nederlandsche onderhandelaars enkel de vrees, dat de ratificeering van het uit Holland te verwachten goedgekeurd tractaat van Britsche zijde zou vertraagd worden, doordien de koning van Engeland ziek was. Inmiddels vroeg Falck verlof naar Holland, ten einde zich voor zijn verblijf in Londen als gezant gereed te maken $(a)$. Ook de Engelsche gevolmachtigden zagen kapitein Elout met. voldoening naar Holland gaan. Den $1^{\mathrm{n}}$ December 1823 had zijn vader aan Canning een particulier schrijven gericht, dat tot dusver onbeantwoord was gelaten. $\mathrm{Nu}$ de kapitein naar Holland ging, wilde de Britsche minister dit goed maken, doch het bleek dat de heer Elout zich reeds op reis bevond. Vandaar dat den $6^{\mathrm{n}}$ Februari een vriendschappelijk schrijven aan minister Elout per post door den

(a) Zie den particulieren brief de. 16 Februari 1824 aan Reinhold in bijl. 24. - Verg. Fagel's Ontslag 396-397; ov. $4 \div 5$. 
Britschen minister werd nagezonden. Deze drukte zijn genoegen uit van met kapitein Elout te hebben kennis gemaakt, beval den nieuwen Britschen gezant bij ons hof, lord Granville - vervanger dus van lord Clancarty - bij minister Elout aan en gaf in de volgende bewoordingen zijne ingenomenheid met Falck te kennen: "As you were not to come to us again, you could not do better than send us M. Falck, to complete, as I hope, the work which some years ago we happily began together" $(a)$. Wanneer men dergelijke betuigingen leest, moet men zich eenige moeite geven, om zich overtuigd te blijven houden, dat de Britsche bewindslieden dat alles maar zonder Mefistofeles' zin schrijven.

Ook de eerste indruk, dien onze Koning van het ontwerp kreeg, na eene conferentie op den $6^{\text {n }}$ Februari met minister a. i. Reinhold, was geenszins ongunstig; doch het moest nog tot "een ernstig onderwerp" van overweging gemaakt worden, haastte zich Reinhold aan onze gevolmachtigden dienzelfden dag te melden (b). Die overweging werd op 's Konings last andermaal minister Elout opgedragen. Onder mededeeling, dat de Koning over het algemeen tevreden was met het ontwerp, richtte Reinhold daartoe een schrijven aan den minister $(c)$, daarbij herhalende zich niet bevoegd te achten om over zaken en belangen te oordeelen, hem "natuurlijk geheel vreemd"; doch "uit een generaal oogpunt beschouwd", kwam het ook hem voor, "dat de overeenkomst, zoo als die door de Plenipotentiarissen is ontworpen, de Nederlandsche magt in OostIndiën concentreert, de afscheiding tusschen onze en de Engelsche bezittingen naauwkeurig bepaalt en een einde maakt aan vele onzekerheden, waaruit nieuwe twisten zouden kunnen ontstaan". Zoo dus geene overwegende bedenkingen anwezig mochten zijn, vervolgde het schrijven, scheen het "allerwenschelijkst", "dat men

(a) Het briefje in Bïdr. E. 172.

(b) „De heer Kap. Elout heeft mij op gisteren ter hand gesteld Uwer Ex. zeer belangrijk rapport van den $1^{\text {n }}$ Februarij $N^{\circ} 8$. Z. M. heeft hetzelve, met en benevens het afzonderlijk rapport van den heer minister Falck, tot een ernstig onderwerp gemaakt van Hoogstdeszelfs raadplegingen en zoodra die overweging tot eenig resultaat zal hebben geleid, zal ik zorgen, dat Uwe Ex. daarvan onverwijld de vereischte kennis bekome. Inmiddels kan ik het genoegen hebben dezelven voorloopig mede te deelen, dat de Koning, met wien ik de eer had dezen morgen te confereren, over het algemeen, bij de eerste inzage der stukken, over de wijze van behandeling scheen te zijn voldaan geweest." (B. Z.)

(c) Opgenomen in Bijdr. E. 189. 
eene gelegenheid, die zich thans anbiedt, om zoo begeerde resultaten te verkrijgen en welke zich welligt nimmer weder zoo gunstig zal voordoen, niet verwerpe, terwijl ik verder vermeen", voegde Reinhold er aan toe, "dat het afsluiten van een soortgelijk traktaat met Engeland in het tegenwoordig tijdstip mede van eenen meer of min voordeeligen invloed voor onze staatkundige belangen in het algemeen zoude kunnen zijn".

Den $10^{\mathrm{n}}$ Februari zond Reinhold andermaal een schrijven naar Londen, met de verheugende mededeeling, dat minister Elout evenzeer met het tractaat tevreden scheen $(a)$. Over het geheel genomen bleek dit ook, toen twee dagen later Elout, wiens medewerking nu aan de gevolmachtigden uitdrukkelijk was medegedeeld, zijne nota van beschouwingen inzond $(b)$ en deze aldus aanving: "Wanneer men het ontworpen tractaat in deszelfs verband beschouwt, dan schijnt de algemeene inhoud uitermate geschikt tot eene goede uitkomst. De wederzijds voorgestelde afstand en ruiling van bezittingen in Indië is wel geregeld. De voorbijgaande geldelijke geschillen zijn meestal naar billijkheid beslist; en zoo al ten aanzien van sommige, zoo wel als ten aanzien van eene en andere niet ingewilligde vorderingen van meer duurzame strekking aan de Nederlandsche zijde twijfelingen zijn te opperen, zoo moeten die niet worden aangedrongen, wanneer de zoo hoog wenschelijke afloop der zaak daardoor eenigzins zou kunnen lijden. Men wenscht dus dat uit dit oogpunt mogen beschouwd worden de weinige bedenkingen, welke men ten aanzien van de bedoelde punten zich zal veroorloven mede te deelen."

De bedenkingen golden vooral Falck's vinding, nedergelegd in de artt. 8, 11 en 12, waarbij voor het opgeven der Engelsche vordering van $100.000 \mathrm{pd}$. st., eenige handelsvoordeelen door ons werden toegezegd $(c)$. Elout's bezwaren waren geenszins gezocht of ongegrond $(d)$. Nederland nam op zich eene vastgestelde hoeveelheid

(a) „Ik ben voor alsnog buiten staat om Uwe Exc. een bepaald antwoord te doen toekomen op de dépêche sub No 8. Ik heb echter reden om mij te vleijen, dat dit tegen den volgenden postdag zal kunnen plaats hebben, daar ik mij heb kunnen verzekeren, dat de heer minister Elout het werk der Plenipotentiarissen gunstig beoordeelt en ik slechts het verslag van Zijne Excellentie's onderzoek ben inwachtende, om hetzelve onverwijld aan den Koning over te leggen en Hoogst deszelfs welbehagen te vernemen, omtrent de aan Uwe Excellentiën te geven voorschriften." (B. Z.)

(b) Opgenomen in Bijdr. E. 200-208.

(c) Zie bl. 144 hiervóór.

(d) Zie mijne critiek in Atjeh 194-195; ov. 36-37. 
specerijen van verschillende soort uit de gouvernementscultuur aan Engeland tegen een tevens bepaalden prijs te leveren: maar als die hoeveelheid niet voorhanden was, wat dan? En ook de verzekering omtrent eene vriendelijke behandeling te Anjer en Tapanoeli kon Elout's goedkeuring niet wegdragen: terecht wees hij er op, tot welke nieuwe twisten enz. zulk een voorschrift wel zou kunnen leiden. Het was van hem volkomen juist gezien om er met ernst op aan te dringen, dat dit stel van bepalingen zou vervallen, dat wij dan maar liever de 100.000 pd. st. moesten betalen $(a)$. Hij maakte nog eenige andere juiste opmerkingen van meer ondergeschikten aard en beaamde ook enkele bedenkingen, die Reinhold bij de toezending van het ontwerp aan Elout dd. 6 Februari, in het midden had gebracht $(b)$; maar hij besloot deze nota van 12 Februari met opnieuw te waarschuwen tegen de artt. 8, 11 en 12. "Zoo", merkte hij op, "men zich de vrijheid veroorloofd heeft om op dit hoofdpunt eenigzins aan te dringen, men moet bij herhaling aanmerken, dat de overige medegedeelde bedenkingen enkel aan de nadere oplettendheid van onze Gevolmagtigden zouden kunnen worden overgelaten en dat het ontworpen traktaat, zoowel als de wijze, waarop de tegenwoordige onderhandelingen zijn voortgezet, Zijner Majesteits bijzondere goedkeuring verdienen."

Reinhold bood de Nota denzelfden dag Zijne Majesteit aan, er bij te kennen gevende, dat hij zich te eerder met de beschouwingen kon vereenigen, "daar Zijne Excellentie de vriendelijkheid gehad heeft mij bij monde omtrent de voornaamste derzelven in te lichten". De Koning, na nog met Elout eene samenkomst gehad te hebben, haastte zich mede denzelfden $12^{\mathrm{n}}$ het stuk aan Buitenlandsche Zaken terug te zenden met opdracht om de gevolmachtigden over de gemaakte bedenkingen in te lichten en de bepaalde lastgeving er bij te voegen, dat de artikelen over de handelsvoordeelen zouden worden vervangen door de bepaling, dat Nederland zeker bedrag had te betalen: "ten einde", luidde het, "1 $1^{\circ}$ de artikelen 8,11 en 12 van het ontwerp worden weggelaten en vervangen door de bepaling eener uit te keeren geldsom, hoogstens ten bedrage van 100.000 pd. st., blijvende de te maken schikkingen, omtrent de wijze en termijnen van betaling dier som, aan het beleid der ge-

(a) Zie Atjeh 197; ov. 39.

(b) In hoofdstuk XVII worden onder ieder artikel Elout's en Reinhold's opmerkingen letterlijk medegedeeld. 
volmagtigden overgelaten; $2^{\circ}$ art. 10 meer in overeenstemming met art. 9 gebragt $(a)$, en door overgifte van alle de noodige bevelen hier in Europa, de zekerheid verkregen worde, dat derzelver onverwijlde uitvoering aan geene zwarigheden zal onderhevig zijn; $3^{\circ}$ de voorgestelde wijzigingen in de artt. 13,14 en 15 in aandachtige overweging te nemen, en diensvolgens te handelen, indien daartegen geene bedenkingen van gewigt bij hen mogten bestaan"(b). Den volgenden dag kreeg Reinhold nog een briefje van wege Zijne Majesteit, waarbij, op verkeerde mededeelingen van onze gevolmachtigden, werd toegestemd, om, in het belang van Engeland, voorzieningen met betrekking tot Atjeh te treffen $(c)$.

Reinhold gaf in eene depêche dd. 13 Februari 1824 onzen gevolmachtigden kennis van hetgeen hem was opgedragen. Kapitein Elout nam den brief naar Londen mede, waaraan toegevoegd was — werd nu daarin bekend gesteld - "eene nota van bemerkingen, door den heer Minister zijnen vader ontworpen". In bijzonderheden was Buitenlandsche Zaken overigens niet getreden; kapitein Elout zou ze mondeling wel nader geven, gelijk deze zijn vader den $14^{\mathrm{n}}$ berichtte $(d)$.

\section{XVI.}

\section{Het ontwerp-tractaat van 1 Februari 1824 in de Elout- bijdragen en in Falck's Ambtsbrieven.}

De bezorger der Elout-bijdragen achtte voor eene juiste kennis der geschiedenis van het tractaat van 1824 noodig, blijkens het op bl. XXVIXXVIII der inleiding aangeteekende, publiceering van het verbaal der onderhandelaars van 1823-24 dan wel van het bij art. 16 der instructie van gevolmachtigden voorgeschreven algemeen rapport. "Die stukken", schrijft hij verder, "waarnaar ik tot nu toe heb uitgezien, zijn niet gevonden. De uitgave daarvan zoude, met andere papieren uit Falck's staatsleven, zijn bezorgd door den Heer Hora Siccama, wien we

(a) De afstand van Benkoelen aan ons (ontwerp-art. 10) was niet op dezelfde wijze geredigeerd als de afstand van onze factorijen in Vóór-Indië aan Engeland (ontwerp-art. 9). Zie hoofdstuk XVII.

(b) Zie hoofdstuk XVII.

(c) Zie Atjeh 198; ov. 40.

(d) Zie Atjeh 198-199; ov. 40-41. 
'de Brieven' te danken hebben. Ze zoude eene wenschelijke toelichting zijn geweest voor de depêches, tien in getal, op uitnemende, den Minister Falck eigene wijze, maar slechts in groote trekken, denkbeelden onderwerpende of resultaten mededeelende, en zelfs op het gewigtig artikel XII $(a)$ (vroeger $\mathrm{XV}$ ) van het tractaat, door mondelinge ontwikkelingen, waarvan geen schrift is opgemaakt, aangevuld."

De heer Siccama schijnt zich die opmerking niet bijzonder te hebben aangetrokken. Zonder er op aan te slaan, schreef hij op bl. 181 van Falck's Ambtsbrieven, over het verblijf van den minister te Londen als onderhandelaar (waaraan Siccama het zonderlinge hoofd gaf: Buitengewoon gezantschap te Londen!): "De mededeeling van slechts twee of drie brieven uit dit tijdvak zal hier wel voldoende zijn, aangezien reeds onderscheiden belangrijke stukken door den druk bekend zijn gemaakt in de merkwaardige Bïdragen enz." - Mij dunkt, dat de heer Siccama, die als amanuensis op de hoogte kon zijn van den gang der zaken, wel een woordje had mogen ten beste geven over hetgeen de bezorger der Elout-Bïdragen niet kon vinden.

Volstrekt zeker kan men nu natuurlijk nooit zeggen, dat de vermiste stukken niet hebben bestaan, maar men mag dit, tenzij het tegendeel wordt bewezen, gerust aannemen, gelijk ik het reeds deed $(b)$. Niet slechts omdat op het departement van Buitenlandsche Zaken van de aanwezigheid dier schrifturen niets bekend is, maar ook, omdat de loop, dien de gedachtenwisseling ten slotte heeft genomen, de behoefte aan het opmaken ervan niet meer deed gevoelen. Waren de onderhandelingen geëindigd, zonder onderbreking en zonder correspondentie met Holland, dan had er aanleiding kunnen bestaan voor de samenstelling van een stuk als art. 16 der instructie van 1820 bedoelde $(c)$; maar de brieven, die de onderhandelaars zonden over den gang der zaken, speciaal ook de toelichting van het tractaat op hun ontwerp van 1 Februari 1824, had hen alles doen zeggen, wat, naar zij vermeenden, viel te zeggen. Naar zij vermeenden: omdat ik nochtans deze opvatting verkeerd vind. Echter niet zóózeer, wijl zij nalieten een algemeen verslag in te dienen - dat bovendien door het onverwacht heengaan van Fagel ook al bezwaar

(a) Over den afstand van Singapore.

(b) Zie Atjeh 209; ov. 51.

(c) Deze bepaling in Bïjdr. E. 89; zie hiervóór bl. 76 . 
kan ingehad hebben - ; want zulk een verslag zou tegenover partij ter andere toch van geene bindende kracht zijn geweest; maar dat geene notulen, geene processen-verbaal, of, in de taal der diplomatie, geene protocollen opgemaakt werden van het op iedere samenkomst verhandelde : dat is de fout. Hoe licht misverstanden konden rijzen, en dan ook later zijn gerezen, hadden de Nederlandsche bewindhebbers nog zoo kort te voren ondervonden ten aanzien van het incident der opofferingen, waarvan ik hiervoren gewag maakte $(a)$; de sterkere partij moge aan eene dergelijke voorzorg minder behoefte gevoelen, voor de zwakkere wordt het eene kracht.

Alzoo enkel aangewezen voor de officieele toelichting der artikelen op de gevoerde correspondentie, lazen we, dat de heeren Elout van Soeterwoude en Siccama hulde brengen aan hetgeen geleverd is; en zoo vindt de laatste, dat Falck zulke perfecte brieven over de onderhandelingen schreef. Nochtans is daaraan absoluut niets bijzonders, veeleer Elout's ontevredenheid over de broddelachtige behandeling volkomen gerechtvaardigd, terwijl ook de manier, waarop dan de brieven door Siccama onder het Buitengewoon gezantschap zijn opgenomen, weinig aantrekkelijk is (b). Evenzeer is de wijze, waarop de Elout-bijdragen in elkander werden gezet, — zoo'n eenvoudig werk anders - geenszins gelijk men die had mogen wenschen, als onder anderen ook nu weer voor de kennis van de wording der artikelen. Immers het eerste volledig ontwerp, hetwelk uit de handen der onderhandelaars kwam, was dat van 1 Februari 1824, maar, in plaats van dit werkelijk historisch belangrijke stuk te doen afdrukken, wordt het

(a) Zie bl. $63-64$.

(b) Het hoofdstuk telt slechts drie brieven, doch alleen die op bl. 180 van 26 December 1823, aangehaald hiervoren op bl. 138, en die op bl. 186 van 1 Februari d.a. v. No 16 over de in- en uitvoerrechten, aangehaald hiervoren bl. 147-148, behooren tot de onderhandelingen; de derde brief op bl. 188 heeft er niets mede uit te staan. Brief $N^{\circ} 1$ was geteekend door onze beide gevolmachtigden, maar brief No 2 alleen door Falck en wel geschreven als minister van Koloniën; dit laatste stuk heeft voor jaartal, gelijk ik reeds opmerkte, de zeer hinderlijke drukfout 1834 , in plaats van 1824 . - De brief No 1 vangt aldus aan: „In de conferentien, welke wij bij het slot onzer dépêche van den $16^{\text {den }}$ dezer meldden, dat tusschen de heeren Wijnn en Falck plaats zouden hebben enz." - Waar nu eene depêche, die tot de verwijzing aanleiding geeft, reeds gedrukt is, en nog wel in het werk, dat een paar regels hooger zoo belangrijk en merkwaardig genoemd wordt, zou het toch niet misplaatst zijn geweest, dat 's lezers aandacht er op werd gevestigd, te meer, wijl zij bijna verloren staat in eene noot op bl. XXVIII der inleiding van Bijdr. E. ; ze werd door mij op bl. 135 aangehaald. 
gesloten tractaat er opgenomen, hetwelk men toch ook wel elders kan vinden! $\mathrm{Nu}$ echter ontmoeten wij daarin alleen de toelichtende depêche, waarbij het ontwerp werd aangeboden; door het vervallen van enkele ontwerp-bepalingen, tengevolge waarvan de artikelen van het tractaat niet overeenstemmen met de verwijzingen in de depêche, wordt het raadplegen der toelichtingen te lastiger. Om nu hieraan tegemoet te komen, laat ik volgen de artikelen van het concept van 1 Februari 1824, aan te geven door de letter C; verder stel ik in noten, hoe de artikelen bij de opneming in het definitief tractaat werden gewijzigd, en voeg onder elk ontwerp-artikel:

$1^{\circ}$ de toelichtingen onzer gevolmachtigden, voorkomende in hunne depêche van 1 Februari $1824=\mathrm{Gm} .(a)$;

$2^{\circ}$ de opmerkingen dd. 12 d. a. v. van minister Elout $=\mathrm{E}(b)$;

$3^{\circ}$ eenige opmerkingen van minister a. i. Reinhold dd. 6 Februari gemakt bij de toezending van het ontwerp aan Elout $=\mathrm{R}(c)$.

\section{XVII.}

\section{De artikelen van het ontwerp-tractaat van 1 Februari met de officiëele toelichtingen er op en aanwijzing der veranderingen voor het definitief tractaat.}

C. (van den considerans). Z. $M$. de Koning der Nederlanden en Z. $\boldsymbol{M}$. de Koning van het Vereenigde Koningrijk van Groot-Brittanje en Ierland, verlangende Hunne respective bezittingen en den handel Hunner onderdanen in Oost-Indië op eenen wederkeerig voordeeligen voet te plaatsen $(d)$, zoo dat de welvaart en voorspoed der beide Natiën, voortaan, ten allen tijde bevorderd kunnen worden, zonder die oneenigheden en dien (e) naijver, welke vroeger $(f)$ de goede verstandhouding verstoord $(g)$ hebben, die bestendig $(h)$ tusschen dezelve behoort te heer-

(a) In Bïjdr. E. 191 vv.; zie bl. 146 hiervóór.

(b) In Bïjdr. E. 201 vv.; zie bl. 151 hiervóór.

(c) In Bïdr. E. 189 vv.; zie bl. 152 hiervóór.

(d) Plaatsen, veranderd in brengen.

(e) dien, weglaten.

(f) vroeger, veranderd, in vroeger dagen,

(g) verstoord, veranderd in gestoord.

(h) bestendig, veranderd in steeds. 
schen $(a)$, en willende zoo veel mogelijk, alle aanleiding tot misverstand tusschen Hunie respective agenten voorkomen, alsmede, ten einde zekere punten van verschil te regelen, welke zich hebben opgedaan bij het ten uitvoer leggen van de Conventie, den $13^{\text {den }}$ Augustus 1814 te Londen gesloten, voor zoo ver dezelve betrekking heeft tot de bezittingen van Z. $M$. den Koning der Nederlanden in Oost-Indië;

Hebben tot Hunne (b) Gevolmagtigden benoemd, te weten: enz.

Gm. Op de redactie der inleiding van de overeenkomst zullen wij gaarne zoodanige reflectiën vernemen, als UHoogEdG., bij de lecture derzelve voor den geest mogten komen. Er is afgesproken, dat er twee texten zullen zijn, een Engelsche en een Nederduitsche, beide wederzijds te onderteekenen, nadat de naauwkeurige overeenstemming derzelve onderling met de meeste zorg zal zijn geconstateerd. Zulks schijnt ons vooral doelmatig te zijn, omdat aan de te maken bepalingen gevolg moet worden gegeven door collegien en beambten, aan welke geene grondige kennis van eene andere taal dan hunne eigene toegeschreven worden kan.

E. De inleiding kan zeker, gelijk de Nederlandsche Gevolmagtigden te kennen geven $(c)$, uitgebreider en meer omvattende zijn; doch de eenvoudigheid, welke in de nu gestelde heerscht, heeft ook groote voordeelen. Er is dus geen reden voor eenige verandering.

C. Art. 1. De beide Gouvernementen (d) verbinden zich om in hunne respective bezittingen in den Oosterschen Archipel en op het vaste land van Indië en Ceylon (e), elkanders onderdanen ten handel toe te laten, op den voet der meest begunstigde Natie; wel verstaande, dat de wederzïdsche onderdanen zich zullen gedragen overeenkomstig de plaatselijke verordeningen van elke bezitting.

Gm. Reeds in 1820 afgesproken en geteekend en, bij examinatie in Nederland, zoodanig bevonden, dat Zijne Majesteit, blijkens de additionele instructie, verklaard heeft in dezelve te kunnen berusten.

NB. Deze aanteekening geldt ook voor de artt. 3 en 4 .

E. De $\mathrm{I}^{\text {ste }}, 3^{\text {de }}$ en $4^{\text {de }}$ artikelen zijn door de Gevolmagtigden genoegzaam toegelicht.

(a) heerschen, veranderd in bestaan.

(b) Hunne, weglaten.

(c) Van die te kennen gave lees ik in de medegedeelde woorden niets.

(d) Veranderd in: De Hooge Contracterende Partijen.

(e) Lees: en op Ceylon. 
C. Art. 2. De onderdanen van het eene Gouvernement (a) zullen, bij den in- en uitvoer, in de havens van het andere (b) in de Oostersche zeeën, geene regten betalen hooger dan ten bedrage van het dubbel van die, aan welke de onderdanen der natie, die de haven bezit, onderworpen zijn (c).

De regten op den in- en uitvoer $(d)$ met Nederlandsche bodems in eene Britsche haven op het vaste land van Indië of op Ceylon, geheven wordende (e), zullen in dezer voege worden gewijzigd, dat deswege, in geen geval, meer betaald worde $(f)$, dan het dubbel der regten, door Britsche onderdanen, voor Britsche bodems verschuldigd $(g)$.

Met betrekking tot die artikelen, op welke geen regt gesteld is, wanneer zij worden in- of uitgevoerd door de schepen $(h)$ der Natie, aan welke de haven toebehoort, zullen de regten, aan de onderdanen of schepen (i) der andere op te leggen, in geen geval meer bedragen dan zes ten honderd.

Gm. Over dit onderwerp is in de conferentiën van 1820 veelvuldig gehandeld. Men was het, op een paar.bedenkingen na, eens, en deze eenstemmigheid heeft de Heer Canning doen gelden bij den thans door hem gebezigden aandrang om een artikel van dezen aard in de te sluiten conventie op te nemen. Onze aanvankelijke verklaring, dat wij daarin niet mogten treden, heeft dien aandrang eer sterker doen worden dan verflaauwen. Wij zouden echter, uit hoofde der stellige bewoordingen van art. 5 der additionele instructie, bij onze weigering hebben volhard, ware het niet dat de laatst ondergeteekende, na eene aandachtiger beschouwing der kwestie, bevonden had, die stellige bewoordingen te moeten toeschrijven aan een misverstand of liever aan eene al te groote bezorgdheid, bij het Dep ${ }^{t}$ van Kolonien gerezen, toen het in de maand November jl., met den Minister van Buitenlandsche zaken te rade ging over de nieuwe voorschriften, van welke 's Konings Plenipotentiarissen voorzien moeten worden. En daar zulks

(a) Veranderd in: De onderdanen en schepen van de eene Natie.

(b) De woorden in de havens van het andere veranderd in: in en van de havens der andere.

(c) De woorden aan welke enz. veranderd in: waarmede de onderdanen en schepen der Natie, aan welke de haven toebehoort, belast zijn.

(d) Het op veranderd in voor.

(e) geheven veranderd in betaald.

(f) betaald veranderd in berekend.

(g) De woorden voor Britsche bodems, verschuldigd veranderd in: en voor Britsche bodems, te betalen.

(h) De woorden door de schepen veranderd in door de onderdanen of in de schepen.

(i) De woorden of schepen geschrapt. 
in een afzonderlijk rapport aan Z. M., hetwelk te gelijk met deze geexpedieerd wordt, uiteen zal worden gezet, onthouden wij ons van hier, door verdere détails, de afwijking van de letter van onze instructiën te regtvaardigen $(a)$.

E. Het $2^{\text {de }}$ artikel evenzeer is wel uiteengezet. De Gouverneur-Generaal van der Capellen gaf in een vertrouwelijken brief van 18 Februarij I82I, zijne vrees te kennen, dat de Nederlandsche belangen door eene gelijkheid van regten zouden lijden, daar de wederzijdsche verhoudingen niet dezelfde zijn. De wijze, waarop nu dit belangrijk onderwerp geregeld is, schijnt een juisten middenweg daar te stellen.

C. Art. 3. De beide Gouvernementen (b) beloven, dat geen traktaat voortaan door ééne derzelve met eenigen Inlandschen (c) Staat in de Oostersche zeeёn te maken, eenig artikel behelzen zal, strekkende, het zij regtstreeks, het zij door oplegging van ongelijke regten, om den koophandel der andere partij van de havens van zoodanigen inlandschen Staat uit te sluiten, en dat, bij aldien, in eene der thans aan weerskanten bestaande traktaten $(d)$, eenig artikel met die bedoeling is opgenomen geworden, zoodanig artikel, bij het shiten des tegenwoordigen traktaats, buiten effect gesteld worden zal.

Over en weder is verstaan (e), dat, vóór het sluiten van dit traktaat, door elke der Contracterende Partijen, aan de andere mededeeling is

(a) Bedoeld wordt het rapport van 1 Februari $1824 \mathrm{~N}^{\circ} 16$ van Falck als minister van Koloniën ingediend, en door mij reeds op bl. 147-148 vermeld. Daarin wordt o. a. gezegd: „In de instructie, volgens welke Z. M. in November jongstleden gewild heeft, dat de onderhandelingen met Engeland over de Oost-Indische zaken zouden worden voortgezet, had de heer Van Nagell op mijnen raad, een artikel gesteld, strekkende tot verwerping van het pIan om de regten van In- en Uitvoer in de wederzijdsche bezittingen in Azië gelijk te maken. Mijn geheugen, waarop ik te dier tijd afging, had mij bedrogen. Zoodanig plan was in 1820 niet in ernstige overweging gekomen, en $\mathrm{U}^{r} \mathrm{M}^{s}$ Plenipotentiarissen hebben het ook thans niet te bestrijden gehad. De bepaling, dat de Engelsche vlag met niet meer dan het dubbelde der regten aan de $\mathrm{Ne}$ derlandsche vlag opgelegd, bezwaard zal mogen worden, en omgekeerd, is geheel iets anders dan die gevreesde gelijkstelling. Zoodanige bepaling kan dus in de te sluiten conventie opgenomen worden zonder overtreding van het bedoelde artikel der additionele instructie, en zonder dat eenig belang óf van Java óf van de Nederlandsche industrie het minste nadeel lijde."

(b) Veranderd in: De Hooge contracterende Partïjen.

(c) Inlandschen: weggelaten.

(d) Het woord traktaten veranderd in overeenkomsten.

(e) Het is verstaan moet niet gelezen worden in den zin, alsof de mededeeling niet gedaan zou zijn; voor zooveel mogelijk heeft ze wel plaats gevonden, gelijk ons nog nader zal blijken. 
gedaan van alle traktaten of verbindtenissen tusschen dezelve respectivelijk en eenige Inlandsche Regering (a) bestaande, en dat gelijke mededeeling geschieden zal van al zoodanige traktaten (b) in het vervolg, door dezelve respectivelijk te shiten $(c)$.

Art. 4. De beide Gouvernementen (d) beloven stellige bevelen te geven, zoo wel aan Hunne burgerlijke en militaire beambten, als aan Hunne oorlogschepen, om de vrijheid van handel, bij artt. 1 en $3(e)$ vastgesteld, te eerbiedigen, en, in geen geval, hinder toe te brengen aan de gemeenschap der inboorlingen van den Oosterschen Archipel met de havens der twee Gouvernementen respectivelijk, noch aan die der wederzijdsche onderdanen, met de havens toebehoorende aan de Inlandsche Vorsten of Staten $\left(f^{\prime}\right)$.

N.B. Voor de artt. 3 en 4 gelden de onderschriften van art. 1. Middellijk hebben juist deze beide vrijhandelsbepalingen er toe geleid, dat Engeland de wederpartij herhaaldelijk den voet heeft dwars gezet bij het gebruik maken van de aan Nederland toegekende oppermacht over Sumatra, waarvoor we ons zoo vele opofferingen hadden getroost. Immers én differentieele rechten, én beperkende kustvaartbepalingen werden door partijen als geoorloofd aangenomen, doch zij konden natuurlijk slechts gewettigd worden, waar de havens onder het gezag van een der partijen stonden. Als dus een inlandsche staat, waarvoor de artt. 3 en 4 golden, ingelijfd werd bij een der partijen, dan hielden die bepalingen op van kracht te zijn, m. a. w. konden differentieele rechten en kustvaartvoorschriften worden gewettigd. Engeland, veel verbindingen met de onafhankelijke streken van Sumatra's Oostkust hebbende, kwam alzoo in nadeeliger verhoudingen, wanneer ons gezag er erkend werd, waarvan het gevolg was, dat men dit dadelijk ging betwisten, in weerwil van het tractaat van 1824. Onze staatslieden zijn voor het gevaarlijke, in de toepassing dezer bepalingen gelegen, eenvoudig blind geweest; van Britsche zijde heeft men dit daarentegen aanstonds, althans in Indië doorzien, gelijk op zulk eene merkwaardige wijze blijkt uit den brief van het Pinangsch bestuur dd. 21 Maart 1825, afgedrukt als bijl. 10 mijner Atjehverhandeling.

(a) Hierachter te voegen: in de Oostersche zeeën.

(b) Lees voor tractaten: verbindtenissen.

(c) Te sluiten veranderd in: aan te gaan.

(d) Veranderd in: Hunne Nederlandsche en Groot-Brittanische Majesteiten.

(e) Veranderd in: artt. 1, 2 en 3.

$(f)$ aan de Inlandsche Vorsten of Staten veranderd in: aan Inlandsche regeringen. 
C. Art. 5. Zij (a) verbinden zich, in gelijker voege, om krachtdadig bij te dragen tot het betengelen der zeerooverijen bij alle Inlandsche Vorsten of Staten (b) in die zeeën. Zij zullen geene schuilplaats of bescherming verleenen aan vaartuigen met welke zeeroof bedreven wordt, en zullen, in geen geval, veroorloven, dat schepen of goederen, door zulke vaartuigen buit gemaakt, in eenige van Hunne bezittingen ingevoerd, bewaard of verkocht worden.

Gm. Over de beteugeling der zeerooverï kon geene bedenking vallen. Reeds in 1820 hadden de Engelsche Gevolmagtigden een bijvoegsel voorgesteld, behelzende, dat men zich over en weder onthouden zoude van elkanders vlag te gebruiken $(c)$. $\mathrm{Zij}$ hebben er thans wederom op geinsteerd, doch eindelijk toegegeven aan onze remonstrantiën omtrent de nutteloosheid van een zoo ongewoon verbod.

E. Het $5^{\text {de }}$ artikel heeft eene allernuttigste strekking. Door deszelfs strenge handhaving mag veel goeds verwacht en veel kwaads geweerd worden.

C. Art. 6. $\mathrm{Er}$ is overeengekomen, dat $(d)$ de beide Gouvernementen aan hunne Officieren en Agenten in Oost-Indië bevel zullen geven, om geene etablissementen $(e)$ op een der Oostersche eilanden op te rigten, zonder voorafgaande magtiging Hunner $(f)$ respective Gouvernementen in Europa.

Gm. Het voorstel tot deze bepaling kwam van de Britsche Gevolmagtigden. Zij zelve schenen overtuigd, dat men zonder een zoodanig middel, niet op den duur gewaarborgd zoude zijn tegen de onaangename gevolgen van overhaaste stappen en ondernemingen, zoo als die van den Heer Raffles. Wanneer wij, van onze zijde, de uitgebreidheid der Nederlandsche etablissementen nagaan, schijnt er geene vreeze te kunnen bestaan voor eenige periculum in mora bij de oprigting van een nieuw etablissement; ten minste niet zoodanig, dat er geen tijd zoude zijn om orders uit Europa af te wachten.

Het zal nu met de goede trouw en de liberaliteit, die in al deze bepalingen doorstralen, overeenkomen, om zich wederzijds, wanneer

(a) Veranderd in: Hunne Nederlandsche en Groot-Britannische Majesteiten.

(b) De woorden bij alle Inlandsche Vorsten of Staten geschrapt.

(c) De Gm. brachten dit onderwerp hier te pas, omdat men over en weer de gewoonte had, de vlag te hijschen van de natie, wier vlag in de zeerooversstreken het meest geëerbiedigd werd. Zie breeder Palembang 505-508; ov. 175-178.

(d) Hier tusschen gevoegd door, en dientengevolge het daarna komende zullen geven veranderd in: zal worden gegeven.

(e) De woorden geene etablissementen veranderd in geen nieuw kantoor.

(f) Lees: van hunne.

7• Volg. II. 
zoodanige orders uitgezonden worden, in tijds te waarschuwen, doch zulks bij de conventie zelve tot eene verpligting te maken, is bij ons onvoegzaam geoordeeld.

Wij hebben voorts, dat artikel discuterende, de Engelsche Plenipotentiarissen bij voorraad op doen merken, dat Nederland waarschijnlijk in de omstandigheid, dat geheel Sumatra thans onder deszelfs invloed geplaatst is, aanleiding vinden zal om er tot de oprigting van een of ander nieuw kantoor te doen overgaan, gelijk het daarentegen van zelve spreekt, dat ook Engeland te dezen opzigte naar verkiezing handelen kan op het Maleische schiereiland $(a)$.

E. Evenzeer (als het $5^{\mathrm{e}}$ artikel) verdient allen bijval het $6^{\text {de }}$ artikel, hetwelk, ware het vroeger overeengekomen, vele heillooze gebeurtenissen zou hebben voorgekomen.

NB. Hoe men van Engelsche zijde het artikel 6 tegen ons keerde, is aangeteekend in Atjeh 205, ov. 47 .

C. Art. 7. Van de toepassing der artikelen 1, 2, 3 en 4, worden de Moluksche eilanden (b) uitgezonderd, tot tijd en wijle het Nederlandsche Gouvernement raadzaam oordeelen zal, van den alleenhandel in specerijen af te zien; maar zoo dit Gouvernement ooit (c), vóór zoodanige afschaffing van den alleenhandel, aan de onderdanen van eenige Mogendheid, anders dan van (d) een Inlandschen Aziatischen staat, eenig handelsverkeer met die eilanden veroorloven mogt $(e)$, zullen de onderdanen van Zijne Britsche Majesteit, op een volstrekt gelïken voet, tot zoodanig verkeer worden toegelaten.

Gm. Dit is mede een der artikelen, bereids in 1820 vastgesteld en door Z. M. gehomologeerd.

E. Het $7^{\text {de }}$ artikel bevat eene vooralsnog noodzakelijke beperking.

C. Art. 8. (Door het vervallen van den inhoud van dit ontwerpartikel, is het hierna volgende 9 er voor in de plaats getreden,) Jaarlijks, te beginnen met 1825, en zoo lang het Nederlandsch Gouvernement den alleenhandel in specerijen blijft handhaven, zullen er te Batavia voor het Britsche Gouvernement worden afgezonderd, en aan zoodanige personen als hetzelve daartoe zal magtigen, afgeleverd

(a) Aan het belang dezer zinsnede werd herinnerd in Atjeh 209; ov. 51.

(b) Hier achter gevoegd: en speciaal Ambon, Banda en Ternate met derzelver onderhoorigheden. Hierover nader op bl. 183.

(c) Het woordt ooit veranderd in immer.

(d) Dit van geschrapt.

(e) De woorden: eenig handelsverkeer ens. veroorloven mogt, veranderd in: veroorloven mogt eenig handelsverkeer met die eilanden te onderhouden. 
de hoeveelheid specerijen, welke zij zullen vragen, voor zoover deze hoeveelheid niet te boven gaat:

$$
\begin{aligned}
& 100.000 \text { 世 nagelen, } \\
& 100.000 \text { 世 notenmuskaat, } \\
& 25.000 \text { \& foeli. }
\end{aligned}
$$

Deze specerijen zullen te Batavia worden betaald, volgens de middenprïzen der openbare verkooping, die de aanvrage het laatst voorafgegaan is en zullen, onder voldoening der gewone regten van uitvoer, naar Groot-Britannië en Ierland of naar de Koloniën van dat rïk moeten worden afgescheept.

op zoodanige gedeelten der voormelde jaarlijksche hoeveetheid als zes maanden na ommekomst van ieder jaar niet zijn aangevraagd, zal alle aanspraak vervallen zïn.

Gm. Tot deze concessie heeft aanleiding gegeven de in onze depêche van 27 Januarij I824 No 7 , vermelde aanvrage onzer mede-Gevolmagtigden, of er dan niet ettelijke voordeelen voor hunne scheepvaart en handel in Oost-Indië uit te denken waren, door het bedingen van welke, zij zich voor verantwoord konden achten wegens het laten varen der huns inziens zoo wel bewezene, pecuniële vordering ten onzen laste. Uit de deswege gehouden ruggespraak zijn voortgevloeid de min beduidende toezeggingen van gunstig onthaal der Britsche vlag in de baai van Tappanuli en aan de punt van Anjer, waarover hierna zal gehandeld worden $(a)$, en eindelijk het onderhavige artikel. Deszelfs strekking en effect zullen mede in het rapport, dat de laatst ondergeteekende heden de eer heeft van in zijne kwaliteit van Minister van Kolonien aan den Koning te rigten, breedvoerig ontwikkeld en toegelicht worden, en bepalen wij ons dus hier tot de aanmerking, dat de Engelsche Plenipotentiarissen, ten overvloede gewaarschuwd zijn, dat de opneming van hetzelve in de project-conventie geheel is voor onze eigene rekening; dat onze instructien daartoe geene bevoegdheid hoegenaamd verleenen en dat wij in geenen deele verzekeren kunnen, dat eene zoo nieuwe en ongewone zaak als het verkoopen van specerijen te Batavia voor andere markten dan de Aziatische, de goedkeuring van het Nederlandsche Gouvernement verwerven zal.

N.B. Het hier vermelde rapport van Falck als minister van Koloniën, haalde ik reeds op bl. 147-148 aan. Omtrent vorenstaand artikel schreef hij:

Ik heb dat artikel herhaaldelijk getoetst aan al hetgeen ik óf van den tegenwoordigen gang des specerijhandels wete, óf van deszelfs

(a) Zie $\mathrm{C}$ art. 11 en 12. 
toekomstigen en reeds voorbereiden loop verwachten kan; doch nergens is mij eene wezentlijke zwarigheid voorgekomen, noch iets dat ons van eene schikking terughouden moet, die de Engelschen de goedheid hebben van als eene concessie aan te merken, en wel als eene concessie, die, gevoegd bij eene paar onbeduidende toezeggingen, hen van eene hetzij dan gegronde, hetzij overdrevene pretensie van I00.000 pd. st. zal doen afzien. Die 225.000 pond specerijen kunnen dan op zijn hoogst $\mathrm{f} 400.000$ kosten. Hoe gering is de som, die daarop kan worden gewonnen! Hoe onbelangrijk de geheele operatie in de schaal des algemeenen handels en zelfs in die van onzen handel! Mijne eenige beduchtheid is voor klagten wegens onopregtheid of misleiding, wanneer na verloop van maar korten tijd, de thans zoo plegtig gestipuleerde gunst door een administratieven maatregel zal worden uitgestrekt tot alle natien, die geld naar de markt te Batavia verkiezen te zenden.

E. Men gevoelt de aanleiding tot het voorstellen dezer bepaling. De Nederlandsche Gevolmagtigden zijn bekend met de moeijelijkheid om de gevraagde som te vinden. Naar het oordeel van den steller dezes is de moeijelijkheid geringer dan die der bepaling zelve.

Eene eerste twijfeling is hoe den prijs te bepalen der af te leveren specerijen, zoolang niet de geheele verkoop op Java is toegestaan; dan toch is er geen marktprijs, d. i. voor de Europesche markt. - Nu worden door het Indisch Gouvernement gedeeltelijk de specerijen verkocht voor de huishoudelijke behoeften van Java en ook van de Chinesche of Indische markt. Het laatste wordt bij openbare veiling uitgevoerd. Men durft niet bepalen of die marktprijs in het ondersteld geval de juiste zijn zou.

Eene andere twijfeling is of niet, hetzij een mislukte pluk, of verongelukte ladingen, of geene genoegzaam voorhanden hoeveelheid goede soorten specerijen, aanleiding tot verschillen geven kan.

Ten derde: zou het niet uit een dezer oorzaken kunnen gebeuren, dat er op Java geene genoegzame hoeveelheid was om elken kooper, vooral Nederlandsche koopers, te gerieven en om Nederlandsche schepen ladingen te bezorgen (een der beweegredenen, waarom men op Java dacht te verkoopen). En wat, zoo dan uit kracht van het traktaat het Engelsche schip werd verzorgd en het daarnevens liggend Nederlandsch schip niets verkrijgt? Die twijfeling staat in verband met Zijner Majesteits vrees, dat zulk eene bepaling te Amsterdam welligt niet welgevallig zal zijn.

Eene vierde twijfeling zet aan die vrees eenige waarde bij. Wanneer het mogelijk was te bepalen en dan nog aan de gemaakte bepaling krachtiglijk de hand te houden, dat de alzoo af te geven specerijen allen in Engeland en dezelfs kolonien zouden kunnen vervoerd en ver- 
bruikt worden, dan zoude het zeker (de heer Falck geeft daarvan goede redenen op) den Nederlandschen handel niet benadeelen of hinderen. Maar indien ééns de specerijen in Engeland zijn, worden ze ook naar andere landen vervoerd. Volgens de opgaven zijn door die landen in 1823 nagelen 74,424 ponden, noten 65,254 ponden, foelie 12,754 ponden verzonden. Deze hoeveelheden staan hoog $(a)$ in evenredigheid tot de af te leveren nagelen I00,000 ponden, noten 100,000 ponden, en foelie 25,000 ponden. $\mathrm{Nu}$ is er reeds in de Britsche pakhuizen nog een groote voorraad. Deze zal dus telkens worden vermeerderd. De uitvoer naar andere landen kan uitgebreid worden; en zal dit niet den handel van Nederland hinderlijk zijn en nog meer dan nu naar elders verplaatsen? Zonderling is het dat men in andere landen uit Engeland ontbiedt, wat men in Nederland tot lagere prijzen en beter soorten krijgen kan. Juist is de aanmerking van den heer Falck; maar welligt is even juist de twijfeling of het niet gebrek aan activiteit en correspondentie bij onze Nederlandsche kooplieden aanduidt. Doch zal de hier voorgedragen vergunning die activiteit opwakkeren of niet? en zal in elk geval niet de mogelijkheid om die activiteit te doen werken, minder worden? althans het den Engelschen niet gemakkelijker maken de Europesche markten te voorzien van een produkt, dat voor het grootste gedeelte het onze is?

Het is wel zoo, de Engelschen doen het zelfde met de opium; maar dit staat niet gelijk, want de fabricatie en het vertier werken geheel anders.

Wanneer men evenwel, om hoogere beweegredenen tot die afgifte van specerijen mogt besluiten, dan is de vraag, of het niet nuttig zou zijn om den indruk bij de kooplieden te verminderen, dat een gelijk beding voor de opium van de Engelsche zijde te leveren, gemaakt werd. Men zou dan op de noodzakelijkheid van dit heulsap voor Indien kunnen wijzen en zoo verdedigen de bepaling omtrent de specerijen, die dan wederkeerig was. De Engeischen zouden er wel toe willen overgaan en dit zou den indruk lenigen. De clausule toch, dat van hetgeen na zes maanden niet is afgehaald, zou gerekend worden te zijn afgezien, zou ons niet verpligten, wanneer eens onze kooplieden, gelijk zij reeds hadden kunnen doen, er zich op toelegden eene leverantie opium aan te brengen.

Dan, men herhaalt het met eerbiedig vertrouwen, de drie genoemde artikelen $(b)$ hebben zoo vele en zoo groote bedenkingen in, dat men

(a) Op bl. 207 van Bijdr. $E$. is dit woord weggelaten, waardoor de redeneering hare beteekenis verliest.

(b) Bedoeld worden, behalve bovenstaande bepaling, de concept-artikelen 11 en 12, die echter op Elout's bezwaren, mede vervallen zijn. Zie Atjeh $194-195$; ov. $36-37$. Op eerstgenoemde bladzijde regel $17 \mathrm{v}$. b. is abusievelijk gesteld, dat het ontwerp-specerij-artikel was art. 10, dit moet zijn art. 8, zoodat tevens het woordje ook in de noot $b$ overbodig is. 
niet aarzelt, aan Z. M. stellig aan te raden veel liever met eene somme gelds, al is het ook de gevraagde, de geheele zaak af te doen, dan bij het traktaat eenige bijzondere en duurzame voorregten toe te kennen, welke men vreest dat van meer dan eene zijde welligt zouden bestreden worden.

C. Art. 9, geworden art. 8. Zïne Majesteit de Koning der Nederlanden staat aan Zijne Groot-Britannische Majesteit af al Zijne etablissementen, factorïjen en bezittingen $(a)$ op het vaste land van Indië, en ziet van alle voorregten en vrijstellingen af, welke, ter zake van deze bezittingen en (b) etablissementen, genoten of gereclameerd geworden zijn.

NB. Zie de toelichtingen onder het volgend artikel.

C. Art. 10, geworden art. 9. Zijne Britsche Majesteit bewilligt, dat de factorï van Fort Marlbourough en al de bezittingen van Hoogstdenzelven of van de Engelsche Oost-Indische Maatschappij op het eiland Sumatra overgedragen worden (c) aan Z. M. den Koning der Nederlanden; en zijne Groot-Britannische Majesteit belooft verder (d), dat op dat eiland geen Britsch kantoor zal worden opgerigt, noch eenig traktaat, onder Britsch gezag, gesloten met eenige der inlandsche Vorsten, Opperhoofden of Staten, op hetzelve gevestigd.

Gm. (over de twee laatste artikelen). Behelzen den afstand eener Nederlandsche en dien van eene Engelsche bezitting. Dat de bewoordingen niet gelijkluidende zijn $(e)$, is toe te schrijven aan de omstandigheid, dat Fort Marlborough of Bencoelen eene bezitting niet van de Kroon, maar van de Oost-Indische Compagnie is, sprekende het overigens van zelf, dat de overdragt desniettemin plaats vinden zal, zonder dat eenige verdere of subsidiaire onderhandeling met de Bewindhebberen dezer Compagnie behoeven plaats te vinden.

Wij mogen voorts niet afzijn de aandacht van UHoogEdG. op het slot van dit artikel $(f)$ te vestigen, vleijende wij ons dat door die stellige en duidelijke uitdrukkingen geheel zal zijn voldaan aan de herinne-

(a) De woorden factorijen en bezittingen geschrapt.

(b) De woorden besittingen en vervallen.

(c) Deze geheele aanhef is aldus geworden: De factorï van fort Marlborough en al de bezittingen van Groot-Brittanje op het eiland Sumatra, worden bij dezen, afgestaan.

(d) Het woord geschrapt.

(e) Ze werden gelijkluidend gemaakt, ten gevolge van de in den tekst volgende aanmerkingen.

(f) $\mathrm{Nu}$ wordt bedoeld bepaaldelijk het concept-artikel 10, en dus niet ook het voorgaand artikel. 
ringen, die wij in de ons toegezonden Nota $(a)$ hebben aangetroffen: dat het op zich zelve aannemelijke denkbeeld, om den invloed van de Britten en van de Nederlanders tot sommige gedeelten van Indië te bepalen, wèl zal moeten omschreven worden.

R. Volgens artikel 9 staat de Koning der Nederlanden aan Zijne Groot-Britannische Majesteit af, alle zijne etablissementen, factoryen en bezittingen op de Vaste kust van Indie enz., terwijl in het volgende art. IO, de Koning van Engeland bewilligt in de overdragt van de factory van het Fort Marlborough enz. De redenen, waarom de bewoordingen van deze beide artikelen niet gelijk zijn, worden opgegeven in de depêche van Plenipotentiarissen, met bijvoeging, dat de overdragt zal plaats vinden, zonder dat eenige verdere of subsidiaire onderhandelingen met de Bewindhebberen der Engelsche O. I. Compagnie behoeven plaats te vinden. Deze verzekering der Plenipotentiarissen neemt ondertusschen niet weg, dat er, naar mijn inzien, uit den aard der zake, op de bewilliging nog iets meer schijnt te moeten volgen, immers dat de afstand door die uitdrukking niet genoegzaam verzekerd is. Om dit eenigzins te wijzigen, geef ik Uwe Excellentie in bedenking of men niet, in plaats van het woord bervilligt, zoude kunnen zeggen, doet afstand van en bewilligt, dewijl toch het artikel niet alleen spreekt van de bezittingen der Engelsche Maatschappij, maar ook van die van Z. G. B. M. en de woorden doet afstand van en bewilligt alsdan in dier voege verstaan zouden kunnen worden, dat zij van toepassing zijn op de eene, zoowel als op de andere dezer onderscheidene bezittingen. Ik onderwerpe deze consideratie aan Uwer Excellenties overweging (b).

E. Het bij het $9^{\text {de }}$ artikel vervatte onderwerp is reeds bij eene vorige gelegenheid behandeld. Het nu bepaalde is juist.

De aanmerking door den heer Reinhold op het Iode artikel gemaakt, heeft veel waarde. De bewoordingen van het $9^{\text {de }}$ en $10^{\text {de }}$ artikel dienen meer gelijk te zijn. Inderdaad schijnt de afstand van Bencoelen daardoor niet genoegzaam verzekerd. Het verledene kon hier het tegenwoordige en toekomende ophelderen. Toen de Nederlandsche Commissarissen in I8I6 op Batavia aankwamen, werd eerst de overgifte van de Indische bezittingen geweigerd, op grond dat er in het geheel geene bevelen te dien aanzien aan het plaatselijk Britsch bestuur waren toegezonden. Toen naderhand de bevelen van de Europesche Britsche regering waren gekomen, wilde hetzelve bestuur wel onder zekere voorwaarde, maar niet anders, over de overgave handelen, omdat zij zich niet verant-

(a) Zie bl. 142.

(b) Namelijk van minister Elout, aan wien Reinhold's stuk gericht was; zie bl. 150 en 152 . 
woord hielden door eenige andere bevelen dan die van het opperste Bengaalsch gouvernement, als hunne immediate superiors. $(a)$.

Men houdt het dus met den heer Reinhold voor hoogst belangrijk en noodzakelijk, dat te dezen aanzien eene meer stellige bepaling in het traktaat voorkome; en men veroorlooft zich wijders, op grond van zeer schadelijke ondervinding, met alle ernst de oplettendheid der Regering in te roepen op de middelen om alle vertraging van uitvoering in Indië voor te komen door het aandringen op de overgifte van alle de noodige bevelen hier in Europa, opdat het Nederlandsch Gouvernement die in deszelfs boezem hebbe.

Voor het overige mag worden aangemerkt, hoe noodzakelijk het is, dat eene bepaling worde daargesteld, waardoor alle bemoeijenis der Engelschen met Sumatra worde uitgesloten, gelijk de Nederlandsche met het Malaksche schiereiland.

N.B. Over de nitvoering van het tot art. 8 geworden conceptartikel 9, zie Factorïen II, hoofdstuk XXXII; over die van het tot art. 9 geworden concept-artikel 10 , zie Benkoelen en Sumatra's Westlust I 526; ov. 65.

C. Art. 11. (Door het vervallen van den inhoud van dit ontwerpartikel en van het volgende, is er het concept-artikel 13 voor in de plaats gekomen.) De baai van Tapanoeli, die begrepen is in de overdragt bij het voorgaande artikel omschreven, zal niet alleen ten allen tijde voor de schepen onder Britsche vlag open en toegankelijk zijn, maar zï zullen ook aldaar, gedurende derzelver verblïf, op den zelfiden voet behandeld worden als de schepen van Z. M. den Koning der Nederlanden.

Gm. Het zoude zeer gewaagd zijn een tijdstip te noemen, waarop schepen van Z. M. den Koning der Nederlanden in het geval zouden kunnen komen van deze baai te bezoeken. Het artikel is dus allezins onschuldig, en het heeft ons te meer verwonderd, dat de Engelsche Gevolmagtigden het als een gedeeltelijk aequivalent eener geldelijke pretensie aangenomen hebben $(b)$, dewijl zij niet onkundig zijn kunnen van hetgeen deswege bij W. Hamilton, den besten schrijver over OostIndie voorkomt.

«Tapanooly (zegt hij «India Gazetteer" p. 799) a British settlement in Sumatra. Lat. $\mathrm{I}^{\circ} 4 \mathrm{O}^{\prime} \mathrm{N}$. Long. $98^{\circ} 5 \mathrm{O}^{\prime} \mathrm{E}$.

"The bay of Tapanooly, with the island of Mansalar, forms one of

(a) Zie over deze beide phasen in de overneming van 1816, Opvattingen 357 en 360 ; ov. 17 è 20.

(b) Zie Atjeh 194; ov. 36. 
the finest ports in the world; but not being in the general tract for British vessels, this harbour has been little frequented for naval purposes."

E. De baai van Tapanoeli is zeer ten dienste. Niemand behoort uitgesloten te worden. Maar welke uitlegging kan indertijd worden gegeven aan het «op gelijken voet behandelen der Britsche en Nederlandsche schepen"? (Men merkt in 't voorbijgaan op, dat de uitdrukking omtrent de behandeling in de baai van Tapanoeli tot geene wijdere uitlegging zou moeten aanleiding geven dan die van Anjer.) (a)

C. Art. 12. (De inhoud van dit concept-artikel is evenals die van het vorige vervallen, waardoor het concept-artikel 14 geworden is art. 12 van het tractaat.) $Z$. $M$. de Koning der Nederlanden verbindt zich om te bevelen, dat de Engelsche schepen, die de punt van Anjer op het eiland Java zullen komen aan te doen, steeds aldaar op de vriendschappelijkste wijze ontvangen en van ververschingen en van al het noodige voorzien worden, even als de schepen onder Nederlandsche vlag.

Gm. Van geen meerder aanbelang (dan art. $I I$ ), hetzij voor de eene, hetzij voor de andere partij, is de verbindtenis om de Engelsche schepen van ververschingen te doen voorzien aan de punt van Anjer. In tijd van vrede spreekt zulks van zelve en bij een onverhoopten oorlog houdt de kracht der verbindtenis op.

E. Het vrienschappelijk onthaal op Anjer is zóódanig in den geest van onze Regering, dat het niet kan of zal geweigerd worden. Een regt op hetzelve te geven, heeft dus van die zijde niets tegen zich; maar een onvergenoegd scheepsbevelhebber klaagt eens en dat nog wel zonder reden, ziedaar een punt van twist tusschen de beide Gouvernementen. De ondervinding leert, dat dit geene ver gezochte onderstelling is.

N.B. Zie de nadere uiteenzetting over het vervallen van de conceptartikelen 8, 11 en 12 Atjeh 194-197; ov. 36-39.

C. Art. 13, geworden art. 10. Hoogst gedachte Zijne Majesteit draagt aan Zijne Britsche Majesteit over de stad en vesting Malakka met derzelver onderhoorigheden, en belooft voor Zich en voor Zijne onderdanen, nimmer in (b) eenig gedeelte van het Maleische schiereiland (c)

(a) Zie het volgende concept-artikel.

(b) Deze geheele aanhef is aldus veranderd: De stad en vesting van Malakka, met derzelver onderhoorigheden, worden bij dezen afgestaan aan Zijne GrootBritannische Majesteit, en Zijne Majesteit de Koning der Nederlanden belooft, voor sich en voor Zijne onderdanen, nimmer op.

(c) Veranderd in: schiereiland van Malakka. 
een kantoor te zullen oprigten, noch traktaten te shiten $(a)$, met eenige der inlandsche Vorsten, Opperhoofden (b) of Staten op dat schiereiland gevestigd.

Gm. De bewoordingen van het laatste gedeelte van dit artikel corresponderen met die, in welke de verpligting der Engelschen omtrent Sumatra uitgedrukt is (art. IO).

E. Het $\mathrm{I}^{\text {de }}$ artikel kan aanleiding geven tot de vraag, of welligt niet beter ware, hier de uitdrukking te bezigen van het «Schiereiland van Malakka», door die van het «Maleische Schiereiland», waaronder b.v. Traganor en eenige andere plaatsen ten onregte zouden kunnen begrepen worden.

N.B. Over de uitvoering van dit artikel, zie Singapore II 404; ov. 92 .

C. Art. 14, geworden art. 11. Zijne Britsche Majesteit staat aan Z. M. den Koning der Nederlanden af, het eiland Billiton en deszelfs onderhoorigheden $(c)$.

Gm. Door ons was de volgende redactie voorgeslagen:

Biliziton en d'eszel's onderhoorigh̉eden worden verk̉laard' begrepen te zijn in den afstand van Banca, bij het traktaat van 1814 bedongen.

Doch wij hebben moeten toegeven aan de ons medegedeelde aanmerking, dat in de preparatoire onderhandeling van 1820 reeds van de Nederlandsche zijde bewilligd was geworden om Calcapoer en Fultha aan den Ganges, als aequivalent voor Billiton te geven, zoodat de afstand van dit eiland thans niet meer erkend worden kan, als in 1814 te hebben plaats gehad. De hoofdzaak is, dat ons regt voor de toekomst boven allen twijfel verheven worde.

E. Het $I 4^{\text {de }}$ artikel (luidende: $» Z$. B. M. staat aan Z. M. den K. der N. af, het eiland Billiton, enz.») schijnt op eene andere wijze te kunnen worden gesteld. $\mathrm{Nu}$ zou het schijnen alsof de overgave van Billiton eene geheele nieuwe zaak was. Ondertusschen is dit zoo niet. De Nederlandsch-Indische regering heeft altijd beweerd, dat Billiton onder den afstand van Banca begrepen was. $\mathrm{Zij}$ heeft aan het Britsch bestuur dit verklaard en er ook daarom de Nederlandsche vlag geplaatst $(d)$.

(a) De woorden: noch traktaten te sluiten, veranderd in: of traktaten te sullen sluiten.

(b) Het woord opperhoofden weggelaten.

(c) Aldus te lezen: Zï̈ne Groot-Britannische Majesteit ziet af van alle vertoogen tegen het besetten van het eiland Billiton en deszelfs onderhoorigheden, door de Agenten van het Nederlandsche Gouvernement.

(d) Zie Opvattingen 375 en 386 ; ov. 35 en 46. 
Het is wel zoo, dat bij de onderhandelingen in 1820 gesproken was van het geven van Calcapoer en Fultha als aequivalent van Billiton; maar ook dit was eene minnelijke schikking, gelijk duidelijk blijkt uit den brief, op 2 I juli door de toen gezonden Nederlandsche Gevolmagtigden aan den Minister van Buitenlandsche Zaken geschreven: «dat namelijk de ruiling van Billiton tegen Fultha in hunne onvervankelijke gesprekken enkel was voorgeslagen om alle noodelooze twisten af te snijden, maar dat zij er verre af waren, om het regt op Billiton op te geven" $(a)$. Daar nu bij het volgend artikel de Koning der Nederlanden afziet van alle vertoogen tegen de bezetting van Singapoor, zoo schijnt het niet te veel gevergd om eene soortgelijke uitdrukking ook ten aanzien van Billiton te bezigen $(b)$.

C. Art. 15, geworden art. 12. Zijne Majesteit de Koning der Nederlanden ziet af van alle vertoogen tegen het bezetten van het eiland Sinkapoer, door de troepen en onderdanen van Groot-Brittanje (c).

Zijne Britsche Majesteit verbindt zich daarentegen om te zorgen, dat op geene der overige eilanden tot het aloude rijk van Djohor behoorende, Britsche kantoren opgerigt, noch met derzelver gezagvoerders of ingezetenen traktaten onder Britsch gezag gesloten worden $(d)$.

Gm. Al. I. Beiderzijds is begrepen, dat, zoodra men het eens was om aan de kwestie over Sinkapoer een einde te maken, de kortste wijze om zulks uit te drukken ook de beste zoude zijn.

Al. 2. Noodzakelijk geacht om voor te komen, dat niet te eeniger tijd ons afzien van alle reclamatie omtrent Sinkapoer zóó uitgelegd worde, dat de Engelschen ook eenige connexie of invloed zouden kunnen pretenderen met of op de eilanden Lingin, Rhio en de Carimons.

En het is hier de plaats om van de zwarigheid gewag te maken, die onafscheidelijk is van het plan om het Nederlandsche en Britsche gezag respectivelijk op Sumatra en Malakka te concentreren. Er liggen namelijk op het schiereiland en achter Sinkapoer eenige landen, die den Sultan van Lingin toebehooren, doch van welke hij weinig partij trekt. Behoudt hij deze, zoo komt hij in eene dubbele aanraking met

(a) Zie ook Factorïjen 456; ov. 172.

(b) Gelijk geschiedde; zie bl. 184.

(c) De woorden door de troepen enz. veranderd in: door de onderdanen van Zijne Groot-Britannische Majesteit.

(d) Deze gansche alinea is aldus veranderd: Daarentegen belooft Zijne GrootBritannische Majesteit, dat geen Britsch kantoor zal worden opgerigt op de Carimons-eilanden, of op de eilanden Battam, Bintang, Lingin, of eenig der andere eilanden, liggende ten zuiden van straat Sinkapoer, en dat met derzelver Opperhoofden geene traktaten, onder Britsch gezag, gesloten zullen worden. 
de Engelschen, die op Malakka en met de Nederlanders, die op Rhio gevestigd zijn, en deze dubbele aanraking kan gelegenheid geven tot verwarring en twist. Van een anderen kant schijnt het eenigzins hard, dat wij hem, onzen vassal en bondgenoot, tot het afstaan van landen verpligten, aan welker bezit een gedeelte zijner titels verbonden is. Hiervan eenige openlijke melding te maken is ons in allen gevalle ongepast voorgekomen. Het Indisch Bestuur heeft de beste gelegenheid om veelgemelden Sultan den drang der omstandigheden begrijpelijk te doen worden, en te maken, dat hij zich denzelven getrooste door het tijdelijk jaargeld, dat hem wegens het gemis van Sinkapoer zal worden toegelegd, eenigzins ruimer te nemen dan de waardij, die het eiland op zich zelve voor hem hebben kan, zoude vorderen.

E. Het $15^{\text {de }}$ artikel, en wel de tweede zinsnede, geeft aanleiding tot de vraag of het niet beter zijn zoude in stede van de uitdrukking «de overige eilanden tot het aloude rijk van Djohor" deze te bezigen: «de overige eilanden in die streken gelegen", ten einde alzoo ook voorgekomen worde de mogelijke twist, of een, of meer dier eilanden daar gelegen, al dan niet tot het Djohorsche rijk behooren of behoord hebben.

N.B. Over de wijze, waarop de Sultan van Djohor werd bevredigd, zie Simgrapore II 403-404, ov. 91-92; over de ontrouwe opvatting der Engelschen van de tweede alinea, zie men aldaar het hoofdstuk op bl. 410, ov. 98: gedrukt hoofdstuk XI, doch bedoeld $\mathrm{X}$.

C. Art. 16, geworden art. 13. Al de koloniën, bezittingen en etablissementen, die ten gevolge der $(a)$ vorenstaande artikelen worden afgestaan, zullen aan de Officieren der respective Souvereinen overgegeven worden op den

$$
\left.\begin{array}{c}
1^{\text {sten }} \text { Maart } \\
\text { of } \\
1^{\text {sten }} \mathrm{Mei}
\end{array}\right\} \ldots .1825(b)
$$

De vestingwerken (c) zullen blïven in den toestand, in welken zij zich zullen bevinden, ten tijde van het bekend worden des tegenwoordigen traktaats in Indië, doch geene vordering .zal, noch aan de eene, noch aan de andere zijjde, geschieden ter zake, het zij van geschut of behoeften van eenigen aard, door de afstaande Mogendheid òf achtergelaten, òf medegenomen, het zï van achterstallige inkomsten of van lasten van het bestuur, hoe ook genaamd.

(a) De woorden ten gevolge der, veranderd in bij de.

(b) De eerste datum werd vastgesield.

(c) Dit woord te lezen: vestingen. In het artikel van het tractaat is hier geene nieuwe alinea. 
Gm. Hoe begeerig wij ook zijn om de bepalingen der te sluiten conventie spoedig ten uitvoer te doen leggen, is er echter bevonden, dat het niet voorzigtig zoude zijn, tot de overgifte der af te stane bezittingen een vroegeren termijn te stellen dan de eerste maanden van I825. Ons Indisch bestuur zal gaarne eenige ruimte van tijd hebben, om de betrekkingen met de inlandsche Vorsten los te maken, die het tot dusverre, ten gevolge van het bezit van Malakka, te onderhouden heeft gehad.

Het slot van dit artikel is zóó ingerigt, dat er geen verschil tusschen de ontruimende en de in bezit nemende partij ontstaan kan. Ieder geniet de inkomsten tot op den dag der overgifte, doch blijft ook verantwoordelijk voor de tot op dien dag loopende schulden, zonder dat er van de verrekeningen kwestie zij, die op Java tot zoovele onaangenaamheden aanleiding hebben gegeven.

Het is als eene van zelf sprekende zaak beschouwd, dat van weêrskanten, zoodra mogelijk na het ratificeren der conventie, bevelen aan de respectieve gezaghebbers in Indie zullen worden afgevaardigd, naauwkeurig met den inhoud van dit stuk overeenkomstig en alle vertraging en uitvlugten afsnijdende.

E. Het $16^{\text {de }}$ artikel schijnt juist; en het tweede gedeelte is zeer geschikt tot het voorkomen van geschillen, gelijk door de Nederlandsche Gevolmagtigden met regt wordt aangemerkt.

N.B. Gelijk gememoreerd, bepaalḍe het artikel den datum van overgave op 1 Maart 1825, naar aanleiding waarvan onze Gevolmachtigden in hunne depêche van 17 Maart 1824 schreven (a): "Aanvankelijk had men ons 1 Mei 1825 voorgesteld, maar ten gevolge der door ons te kennen gegeven beduchtheid, heeft eindelijk 1 Maart van dat jaar de voorkeur verkregen, hebbende men berekend, dat de orders eerst uit Europa zouden kunnen worden verzonden na de uitwisseling der ratificatien, namelijk in Junij aanstaande, en dat er eenigen tijd aan de respectieve Opperbestuurders gelaten worden moest om, na dezelver ontvangst, dien overeenkomstig instructien van Batavia en Calcutta aan die hunner onderhoorigen te doen toekomen, welke met de overgifte en overname van Malakka, Bencoelen enz. zullen belast worden."

De brief schijnt minder gelukkig gesteld, want de redeneering zou eigenlijk geleid moeten hebben tot het vaststellen van den datum van 1 Mei 1825, hetwelk ook, blijkens hetgeen geschied is, beter zou geweest zijn.

Niet vóór Januari 1825 heeft onze Indische regeering het tractaat

(a) Deze depêche wordt nader op bl. 187 vermeld. 
ter uitvoering ontvangen. Het Opperhoofd der Nederlandsche factorijen kreeg eerst den last tot overgave dd. 9 Mei 1825; de bezittingen werden in Juni d.a. v. overgegeven: zie Factorijen $477-479$, ov. 193-195; Malakka werd overgegeven dd. 9 April 1825: zie Singapore II 405, ov. 93; Benkoelen namen wij over dd. 6 April 1825: Sumatra's Westkust I 527, ov. 67 (a). Ten aanzien der ontevredenheid door onze late verschijning voor Benkoelen, zie Benkoelen 287, ov. 5 .

C. Art. 17, geworden art. 14. Al de ingezetenen van de landen aan de twee Kroonen respectievelijk (b) afgestaan, zullen, gedurende den tïjd van zes jaren, te rekenen van de ratificatie des tegenwoordigen tractaats $(c)$, de vrijheid behouden van $(d)$, naar welgevallen, over hun eigendom te beschikken, en zich, zonder hinder of belet, te begeven werwaarts zij zullen goed vinden.

Gm. Schijnt geene opheldering te behoeven.

N.B. Over de toepassing van dat artikel met betrekking tot Benkoelen, zie Benkoelen, hoofdstuk II en III.

C. Art. 18, geworden art. 15. De twee contracterende partijen komen overeen, dat de landen en etablissementen bij art. 9, 10, 13, 14 en 15 vermeld, nimmer aan eenige andere Mogendheid zullen overgedragen worden (e). In geval dat eenige dier bezittingen door eene der thans Contracterende Partijen verlaten wordt, zullen hare regten op $(f)$ dezelve, onmiddelijk op de andere Partij overgaan.

Gm. Het zelfde valt te zeggen (dat de bepaling geene opheldering behoeft) van de groote voorzorg, die hier, op aanzoek der Britsche Gevolmagtigden, bepaald is. Zij komt eventueel den Engelschen niet alleen, maar ook ons ten bate, die dus kans hebben, om vroeg of laat onzen invloed weder op Sinkapoer te doen gelden, in geval dit eiland deszelfs populariteit verliezen en vervolgens door het Engelsche Bestuur ge-

(a) Aldaar op bl. 543, ov, 83, midden in, wordt gesproken van „de tot het Nederlandsch gezag teruggekeerde Tapanoelische landschappen". Ze hadden echter nooit tot Nederland behoord.

(b) De woorden aan de twee Kroonen respectievelijk vervangen door: bï dezen.

(c) Veranderd in: van het tegenwoordige tractaat.

(d) Veranderd in: vrïheid hebten om.

(e) Deze zinsnede is geworden: De Hooge Contracterende Partïjen komen overeen, dat geen der landen of etablissementen, bij art. 8, 9, 10, 11 en 12 vermeld, immer aan eenige andere Mogendheid zal mogen overgedragen worden.

(f) Dit woordje op is veranderd in tot. Men zou zeggen, dat „op" beter was. 
oordeeld worden mogt de kosten van bezetting en onderhoud niet meer waardig te zijn.

N.B. Men leze over deze absurde bepaling Singapore II 391, ov. 79.

C. Art. 19, geworden art. 16. De beide Souvereinen verklaren, dat ten gevolge der hierboven omschrevene schikking $(a)$ alle rekeningen of vorderingen, voortgesproten uit de teruggave van Java en andere etablissementen aan de officieren van Z. M. den Koning der Nederlanden in Oost-Indië, zoo wel die, welke het onderwerp hebben uitgemaakt eener conventie op Java, den $24^{\mathrm{n}}$ Junij 1817, tusschen de Commissarissen der beide Natiën gesloten, als alle andere, hoe ook genaamd, finaal en ten volle afgedaan zïn (b).

Gm. Ten einde te doen beoordeelen van welk gewigt voor ons deze renunciatie aan de pecuniële vorderingen is $(c)$, nemen wij de vrijheid van te verwijzen naar de bijlage $B$ van onze depêche $n^{\circ} 7$ en naar den inhoud van die depêche zelve $(d)$. Er is in den loop der onderhandelingen meer dan één tijdstip geweest, waarop wij ten eenenmale moesten wanhopen het immer zoo ver te zullen brengen.

E. (in verband met zijne bedenkingen tegen de ontwerp-artikelen 8,11 en 12):

Het is hoogst belangrijk en vóór alles te wenschen, dat het te sluiten traktaat alle bestaande verschillen niet alleen afdoe, maar ook dat het nieuwe voorkome, en althans niet de bron van nieuwe worden kan.

Uit dit oogpunt schijnt het verkiesselijk in eens eene somme gelds af te betalen, dan wel ter besparing dier som, voorregten op den duur voor alle tijden toe te staan, welke welligt aanleiding geven zullen, immers kunnen, tot verkeerde opvattingen, klagten en wat van dien aard meer is. Konden dus de gevraagde roo.000 pd. st. worden uitgekeerd, of kon vermindering nog van de Britsche zijde worden verkregen, of eindelijk de som in termijnen voldaan worden, dan althans zou (onder verbetering) zulk eene afdoening meest aan te raden zijn.

Men gevoelt wel, dat eene vermindering niet gemakkelijk te verkrijgen zal zijn, men zou anders onvervankelijk nog de volgende redeneringen kunnen bijbrengen.

Het crediet-papier, dat in handen van het Nederlandsche Gouver-

(a) Deze aanhef veranderd in: $\mathrm{Er}$ is overeengekomen, dat.

(b) Voor de woorden afgedaan zïn kwamen in de plaats: afgedaan zullen zijn, behoudens de betaling eener som van honderd duizend ponden sterling, van den kant der Nederlanden; te bewerkstelligen in Londen, vóor het einde van het jaar 1825.

(c) Natuurlijk heeft dat betrekking op het ontwerp-artikel.

(d) Dit belangrijke stuk nam ik op als bijl. 9 Factorïen II. 
nement ten tijde der verovering van Java was, en meer dan Rop. 300.000 bedroeg, was waarlijk reeds ter vernietiging ingetrokken. De tegenwerping, dat het niet bewezen is, wordt geheel ontzenuwd door het voorgevaliene. Alle boeken en papieren zijn in handen van het Engelsch bestuur van Java gekomen en daarin heeft de allergrootste wanorde geheerscht. Daarna is een ambtenaar door het Britsch Bestuur zelf met het in orde brengen van dit archief belast, maar veel is er uit gemist; door welke toevallen is moeijelijk te bewijzen.

Eene andere bedenking is nog gerezen op het in rekening brengen van de Rop. 440.000 wegens twee betaalde, doch nog niet verrekende termijnen van de promissory notes, gesproten uit de maatregelen omtrent Bezoeki en Panaroekan genomen. Wat de helft dier som betreft, welke eerst met I5 September I8I7 zou zijn vervallen geweest, voor deze teruggave van onze zijde pleit de billijkheid. Maar de termijn, verschenen I5 September I8I6, schijnt noch naar regt, noch naar billijkheid geheel te kunnen worden gevorderd. Daar de inkomsten van I8I6 voor de helft aan het Britsch, voor de wederhelft aan het Nederlandsch Gouvernement zouden worden toegekend, hetwelk eene zeer billijke verdeeling is, zoo schijnt ook juist deze som althans niet meer dan tot de helft, dat is tot Rop. II0.000, ten laste van Nederland te kunnen gebragt worden.

Deze twee artikelen van Rop. 300.000 en Rop. I00.000 zouden eene aanzienlijke vermindering op de $100.000 \mathrm{pd}$. st. uitmaken.

Indien nu evenwel de nadere aandrang daartoe van geen goed gevolg is of kan zijn, zoodat die is af te raden, hetgeen ter beoordeeling van de Nederlandsche Gevolmagtigden veilig is over te laten, dan zoude eene tweede vraag zijn, of ook de nu gevorderde som in termijnen kon worden betaald, al ware het met renten; er zou dan geene volstrekte onmogelijkheid tot betaling zijn. Vooral niet (en dit mag men nog in overweging geven), wanneer die som in Indië kon betaald worden. Zoo liep dan eindelijk onze geheele aanraking te niet, waarop groote prijs moet worden gesteld; ja, men stelt daarin zoo veel belang, dat men, al moest die som hier te lande worden voorgeschoten, nogthans Z. M. ten hoogste zou aanraden om tot zulk eene opoffering te besluiten. Men is bereid daarover nader zijne gedachten te laten gaan. Intusschen kan de som in het traktaat worden toegezegd.

c. Art. 21, geworden het slotartikel 17. Het tegenwoordige traktaat zal worden geratificeerd en de ratificatiën zullen worden uitgewisseld, binnen den tïd van vier maanden te rekenen van de dagteekening dezer $(a)$.

(a) De woorden na uitgewisseld veranderd in: uitgewisseld, te Londen, drie maanden na dato dezer, of eerder, indien mogelijk. 
Gm. Wij hebben vier maanden gesteld, omdat de Staten-Generaal, aan welke de conventie vóór de ratificatie moet worden medegedeeld, eerst in Mei aanstaande hunne zittingen zullen hervatten.

E. De $I 7^{\text {de }}, I 8^{\text {de }}, I 9^{\text {de }}$ en $20^{\text {ste }}$ artikelen van het traktaat, worden door de Gevolmagtigden juist toegelicht en betoogd $(a)$.

\section{XVIII.}

\section{Het ontwerp-tractaat en de daarbij behoorende Nota's van Maart 1824.}

Wij hebben op bl. 153 gezien, dat kapitein Elout naar Londen terugging met de dd. 13 Februari geteekende depêche van minister a.i. Reinhold, houdende de bemerkingen, die op het ontwerp van de gevolmachtigden waren gemaakt. De minister had zijn schrijven besloten met de verwachting, dat nu de zaken zoo ver gevorderd waren, alles zich wel tot wederzijdsch genoegen schikken en hij dus spoedig een geteekend tractaat terugontvangen zou. Zoo gemakkelijk wikkelde zich echter de zaak niet af.

Eerst verliepen er na kapitein Elout's terugkomst te Londen ettelijke dagen, alvorens onze gevolmachtigden de Britsche onderhandelaars in hunne parlementaire drukten konden overhalen tot het houden eener voltallige conferentie; en toen men eindelijk den $23^{\mathrm{n}}$ Februari in de gelegenheid werd gesteld opening van zaken te geven, verklaarden Canning en Wynn het wegvallen der artikelen over de handelsvoordeelen "a serious disappointment", waarover men niet licht heen kon (b).

Ontevreden gaven ze te kennen, dat de Oost-Indische Compagnie met de beraamde schikkingen genoegen had genomen; nu zou men haar opnieuw moeten oproepen; en wat hadden wij dan voor het weggevallene aan te bieden? Onzerzijds werd geantwoord, dat de verkrijging van Singapore, Malakka, enz. toch waarlijk genoeg was. De Britsche onderhandelaars wilden hiervan echter niet weten, evenmin van het daarop gevolgd aanbod tot betaling door Nederland van 50.000 pd. st.; zulk eene geringe som oordeelde

(a) Ook dus het $18^{\circ}$ ontwerp-artikel, geworden art. 15; verg. Singapore II 391 ; ov. 79 .

(b) Zie het rapport onzer onderhandelaars van 24 Februari 1824 op bl. 210 Bïdr. E.

7• Volg. II. 
Canning beneden de waardigheid der contracteerende mogendheden! Dan moest het minstens dubbel zooveel zijn, gelijk vroeger was voorgesteld. Alles scheen nu weer door de Britsche gevolmachtigden op losse schroeven gesteld te worden. Noord-Amerikaansche bedoelingen met Atjeh werden uitgespeeld tegen onze wenschen, dat Engelaud zich buiten Sumatra zou houden (a). Malakka en de factorijen in Vóór-Indië stonden wij onvoorwaardelijk af, maar tegen onze verkrijging van Benkoelen rezen ineens bezwaren. Of eigenlijk niet in ééns, maar zij stelt in het licht de billijkheid van minister Elout's klacht over de verbrokkelde behandeling der verschillende onderwerpen. In plaats van geene ontwerp-conventie naar Nederland te zenden, wier bepalingen niet als deugdelijk aangenomen konden beschouwd worden, bleek men van Britsche zijde verkeerd ingelicht over het Atjeh-contract van 1819 en wilde men zoo gaaf Sumatra niet meer aan ons overlaten; in plaats van Benkoelen als onvoorwaardelijk verkregen te kunnen beschouwen, heette het bij de toezending van het ontwerp in de op bl. 146 vermelde depêche door onze onderhandelaars dd. 1 Februari naar Nederland gezonden : "Daar tot de cessie tegen de begeerte van bewindhebberen der Oost-Indische maatschappij besloten is, tracht men deze machtige heeren ten minste in de schikkingen van gering aanbelang zooveel mogelijk ter wille te zijn. Men heeft ze deswege geraadpleegd, maar zij hebben nog niet geantwoord." Die machtige heeren zouden er wel wat spoed achter hebben gezet, indien onze vertegenwoordigers pertinent op antwoord hadden gestaan vò̀r het vertrek van hun zendeling. Wij schenen echter nog niet duur genoeg het Engelsche spel, van steeds te wachten op niet komende antwoorden, te hebben betaald, en zoo moesten Falck en Fagel nu op de conferentie van 23 Februari vernemen, dat de ruggespraak met bewindhebbers nog niet was afgeloopen! Ze verlangden o. a. allerlei waarborgen voor eene goede behandeling door ons van de planters in Benkoelen, van de bevolking en van al wat de Britsche deugdzaamheid bij zoo'n gelegenheid voor den dag weet te brengen.

Onze gevolmachtigden namen toen nog even eene houding aan door eene dergelijke verzekering als bestanddeel van het tractaat volstrekt af te wijzen, hetgeen eene levendige en ernstige gedachtenwisseling deed ontstaan. Fagel en Falck kregen intusschen daaruit den indruk, dat aan deze quaestie nu vooral waarde werd gehecht, wegens de

(a) Zie Atjeh 199; ov. 41. 
fatale intrekking der landverhuur in de Javasche vorstenlanden, waardoor ook Engelsche en Schotsche huurders zeer benadeeld werden; eene gebeurtenis, die, helaas! juist destijds in Europa bekend werd. Dan drongen de Britsche vertegenwoordigers aan - ook al weder eene nieuwigheid! - op eene uitvoerige vermelding der eilanden, die beschouwd moesten worden, als te behooren tot den Molukschen archipel, waar ons specerij-monopolie bestond dat Engeland beloofde te eerbiedigen. Het tijdelijk verbod tegen den vreemden handel aldaar wenschten zij tot de voornaamste specerijeilanden beperkt te zien, als Ambon, Banda, enz., zoodat niet alle bevoegdheid werd afgesneden tot het onderhouden van de betrekkingen, welke de Engelsche walvischvaarders sedert eene reeks van jaren met andere door ons niet bezette eilanden onderhielden.

Moest derhalve het geheele ontwerp weer omgewerkt worden? Bij het opbreken der vergadering meenden onze gevolmachtigden de geopperde bezwaren te kunnen ondervangen zonder deze omwerking; doch wat de geldquaestie betrof, waren zij voornemens om bij eene volgende bijeenkomst, zoo noodig, de $100.000 \mathrm{pd}$. st. toe te staan. Indien dit echter plaats vond, schreven zij aan Buitenlandsche Zaken dd. 24 Februari, met sarcastische onderstreping der slotwoorden: "Zoo behoort hiertoe ten minste een ruime termijn te worden toegestaan en van alle stipulatie van interest te worden afgezien; want ook dit, mogen wij op onze beurt den heer Canning te gemoet voeren, zoude beneden de waardigheid der contracterende mogendheden $z \ddot{j} n^{\prime \prime}(a)$.

En wat was nu het middel om aan de bedenkingen der Engelsche heeren tegemoet te komen, zonder algeheele omwerking van het tractaat? - Miskennende de voordeelen van een in zoo scherp mogelijk omlijnde formules gestelde contract, gaat men deze formules waarlijk verwateren door er memoriën aan te hangen, die van gelijke contractueele waarde zouden worden beschouwd en waarin zelfs toezeggingen werden gedaan over onderwerpen, die geheel en al buiten het verdrag waren gebleven! Een unicum zal het wel zijn in de geschiedenis der diplomatie. Het denkbeeld van zulk eene behandeling was uitgegaan van onze gevolmachtigden; wat natuur-

(a) Onderstreept zijn de gespatieerde woorden in het oorspronkelijk stuk; dat blijkt niet uit $B i j d r$. E. 212. Een paar regels te voren op bl. $212 B \ddot{j} d r . E$. wordt er gerept van het plan der gevolmachtigden, „om in de uitbetaling de volle som van 100.000 pd. st. te bewilligen". Dat de moet zijn "der". 
lijker, zou men zeggen, dat zij dan ook ten minste het initiatief der uitvoering op zich namen, waardoor althans eenige beperking gewaarborgd zou worden. Maar dit weder liet men aan de tegenpartij over, en zoo ontstond eene breede Nota der Engelsche plenipotentiarissen, beantwoord door eene even breede Nota van Nederlandsche zijde, waarvan de redactie over en weer mede eerst was goedgekeurd.

Het eerste stuk ving aan met de verwachting, dat men de bepalingen van het tractaat "opregtelijk en ter goeder trouw" zou ten uitvoer brengen; maar wijl niet alles voor bepalingen vatbaar was, achtte men nog noodig "eene rondborstige verklaring hunner voornemens en een gemeen overleg ten aanzien der te volgen beginselen". - De Ned. Nota vond weliswaar, hetgeen "opzettelijk" bij tractaat was vastgesteld, genoegzaam "om gemeenschappelijk alle onzekerheid op te heffen, welke zich in het vervolg zoude mogen opdoen", maar nu de wederpartij er anders over dacht, makkte men ook geen bezwasr, de Eng. Nota op den voet te volgen, ten einde "in eene zoo gewigtige zaak niets aan het toeval over te laten". - De Eng. Nota begint dan te herinneren, dat uit de afkeuring van Raffles' handelingen, wij de overtuiging moesten hebben geput "van de naauwkeurigheid met welke Engeland zijne verbindtenissen altijd gestand doet". In deze waarlijk brutale bewering berusten onze gevolmachtigden met eene stilzwijgende toestemming, niettegenstaande wij in het tractaat eene uitdrukkelijke schuldbekentenis van Engelsche zijde, zij het dan ook te vergeefs, hadden verlangd $(a) !-$ De Eng. Nota neemt vervolgens acte van onze "plegtige ontkenning" - in zulke ellendige stukken is natuurlijk alles aangedikt met bijvoegelijke naamwoorden - over "eenig voornemen om, in den Oosterschen Archipel, hetzij naar staatkundige overmagt of naar uitsluitenden handel te streven". En de Ned. Nota protesteert weder niet tegen de opvatting, om het ontkennen van een feit, zooals het oogenblik aangeeft, verbindbaar te verklaren voor hetgeen misschien de dag van morgen zou mogen brengen. Het doel van het tractaat was juist om onze staatkundige overmacht in den Archipel te vestigen, en nu waarlijk gaan wij dat alles weer op losse schroeven zetten: "met een waar genoegen", schrijft de Eng. Nota. Nu, dat laat zich voorstellen; maar waren onze Nederlandsche diplomaten dan kinderen $(b)$ ?

(a) Breeder in Atjeh 202; ov. 44.

(b) Verg. Atjeh 202-204; ov. 44-46. 
- De Eng. Nota zegt gaarne te erkennen "de bereidwilligheid met welke de Nederlandsche gevolmagtigden tot schikkingen zijn toegetreden, berekend om de grootste vrijheid van handel, tusschen de onderdanen der beide Kroonen en derzelver onderlinge bezittingen in dat gedeelte der wereld, te bevorderen". - De Ned. Nota berust weder in deze lofspraak op de Britsche diplomatie, alsof wij tot deze bereidwilligheid genoopt waren geworden; had dan niet de geschiedenis der Hindostansche factorijen en de Raffles-contracten geleerd, dat de Britsch-Indische politiek zéér uitsluitend was? De Eng. Nota betreedt het terrein van ons Molukken-monopolie; de Ned. Nota geeft daarop eene bevredigende verklaring. - De Eng. Nota komt op de territoriale ruilingen, "welke nuttig zijn geoordeeld, om alle wrijving van belangen te vermijden"; deze ruilingen leggen, zoo staat er, de Britsche gevolmachtigden "de verpligting op om eenige ophelderingen te geven en te vragen, met opzigt tot de onderhoorigen en bondgenooten op het eiland, van welke het staat op te breken". Zoo brengt de Nota in eens Atjeh op het tapijt; wat er van gezegd werd, wat er op geantwoord werd, deze armelijke behandeling zette ik bereids elders breedvoerig uiteen $(a)$. Dan brengt de Eng. Nota Benkoelen ter sprake en even goedmoedig antwoordt men daarop van onze zijde $(b)$; wij gaven verzekeringen in een stuk, dat gelijke kracht van het tractaat zou hebben; terwijl de Nederlandsche gevolmachtigden te voren hadden verklaard, dat zij van dergelijke verzekeringen in een tractaat niet wilden weten; het fijne verschil bleek te liggen in het openlijke, onze gevolmachtigden dus verwachtende, dat de Nota's in een geheim archief zouden opgeborgen worden; 't mocht wat $(c)$ ! Ook in een ander opzicht werden zij uit hunne rol gedrongen. In hunne Nota, zooals die oorspronkelijk was gesteld, werd in uitgebreide en sterke bewoordingen, overeenkomstig van Buitenlandsche Zaken ontvangen bevelen, gevorderd, dat Engeland stellige orders zou geven omtrent de overgave van Benkoelen, opdat wij niet hetzelfde schandaal zouden ondervinden als in 1818 met de overneming van Padang $(d)$; doch, terwijl men ons wel indirect herinnerde aan hetgeen geacht werd onvrijzinnig te zijn, verzochten de Britsche gevolmachtigden deze Padangsche herinneringen - "Zoo weinig strookende met den

(a) Atjeh 204-210; ov. 46-52.

(b) Zie de bewoordingen in Benkoelen 283-285; ov. 1-3.

(c) Verg. Atjeh 200-201; ov. 42-43.

(d) Over het destijds gebeurde, zie Sumatra's Westkust $\amalg$ II 210-217; ov. 6-13. 
vriendschappelijken afloop der onderhandelingen"!! - weg te laten. Dezerzijds meende men daarop te moeten toegeven, niet alleen op grond der overtuiging van Engelands goede trouw, hm! maar ook naar aanleiding van een door Wynn aan Falck gezonden briefje, waarin eene stellige belofte ten aanzien van de overgave voorkwam. "We will profit", luidde namelijk de zinsuede, "from the recollection of what then passed and take every possible precaution to render our orders so positive and definitive that it may not be possible to raise any cavil or pretence for postponing their execution." Vandaar, dat onze gevolmachtigden ten slotte niet verder gingen, dan tot de verklaring zich door "een onbeperkt vertrouwen" genoopt te vinden, "er niet op aan te dringen, dat de voorschriften en bevelen, welke aan de Engelsche Regeringsmagten in Indie zullen worden gegeven, met opzigt tot de overgave van Fort Marlborough en deszelfs onderhoorigheden in zoodanig duidelijke, naauwkeurige en stellige bewoordingen vervat zijn, dat men in dezelve geenerhande grond van onzekerheid, noch eenig voorwendsel tot uitstel vinde; wel verzekerd zijnde dat de Heeren Gevolmagtigden, na in de vervulling van hunne taak $(a)$ met zoo veel gematigdheid en opregtheid te werk te zijn gegaan, ook zullen weten te zorgen dat de uitslag van den gemeenschappelijken arbeid niet worde in gevaar gebragt, ter zake van ondergeschikte belangen en redenen".

Het slot der Eng. Nota eindigt met een vuurwerk. Zij wenscht onze gevolmachtigden geluk "met den gunstigen afloop hunner onderhandelingen"; ze hoopt, "dat door de overeenkomst, welke nu is tot stand gebragt, de handel der beide Natiën bloeijen zal"; ze wenscht, "dat de Bondgenooten de goede verstandhouding, welke van oudsher tusschen dezelve bestaan heeft, in Azië niet minder dan in Europa, ongeschonden zullen bewaren." Welke van oudsher bestaan heeft: dat staat er zoo waar; maar vlak er op volgt, dat de overeenkomst een einde maakt "aan de oneenigheden, welke gedurende twee eeuwen onderscheiden maal aanleiding hebben gegeven tot meer of min ernstig ongenoegen"!! "Geene mededinging" zal meer plaats vinden, heet het verder, tusschen beide natiën in d'n Oost, "dan alleen ter meerdere bevestiging van die beginselen van milde staatkunde, welke beide op den huidigen dag, voor het oog der wereld, plegtig hebben erkend." En onze gevolmachtigden, voor het oog der wereld! op dezen onzin evenzeer aanslaande, schrijven

(a) Op bl. 234 Bïdr. E. de drukfout zaak. 
dat ook zij wenschen, "dat de wederzijdsche Agenten in de Aziatische Bezittingen bestendig blijken geven van doordrongen te zijn van het gevoel der verpligtingen, welke twee bevriende en met waarlijk vrijgevige inzigten bezielde Natiën, te vervullen hebben, zoo wel jegens elkanderen als ten aanzien der inboorlingen, die den loop der gebeurtenissen of de verdragen onder derzelver invloed hebben geplaatst". (a)

Tegelijkertijd waren ook in de artikelen van het ontwerptractaat eenige wijzigingen gebracht, zoowel om aan bezwaren der Nederlandsche regeering als van de Engelsche gevolmachtigden tegemoet te komen.

Hiervoren lazen we $(b)$, dat men van Britsche zijde uitdrukkelijk bekend wilde gesteld zien tot welke eilanden zich het Moluksche monopolie zou bepalen, daar men anders beschuldigd kon worden van eenigen handel te hebben opgeofferd, die destijds door de Engelschen werd gedreven. Ten einde hieraan tegemoet te komen, werd, na velerlei discussie, in art. 7 niet enkel gezegd, dat van den vrijen handel werden uitgezonderd "de Moluksche eilanden", doch daaraan nu toegevoegd: en speciaal Ambon, Banda en Ternate met derzelver onmiddellijke onderhoorigheden. "Doch", schreven onze gevolmachtigden aan Buitenlandsche Zaken in hunne depêche van 17 Maart 1824 over de vrees der Engelschen betrekkelijk de oorspronkelijke redactie $(c)$, "Doch ondersteld dat deze vreeze eenen redelijken grond heeft, dan kunnen wij niet inzien, dat hun die invoeging in het allerminste baten zoude, of dat zij immer de generale uitzondering van alle Moluksche eilanden zouden mogen ontkennen, omdat er speciale melding is gemaakt van ettelijke derzelve. In allen gevalle en bij onverhoopte en schier onmogelijke verschillen te dien opzigte, zouden ons de woorden met derzelver onmiddellijke onderhoorigheden meer te stade komen dan thans van de Engelsche zijde schijnt te worden vermoed." Men nam hier dus met het oog der wereld een loopje.

De weglating der door ons toegezegde handelsvoordeelen bij de artt. 8,11 en 12 van de concept-conventie had tengevolge de wederopneming van de door ons te betalen som ad 100.000 pd. st., welke in art. 16 van het tractaat werd vastgesteld. "Het gevoel dezer naamwaardige opoffering" werd echter niet weinig verzacht, meenden onze

(a) In de noot $a$ van Atjeh 201, ov. 43, vindt men de plaatsen genoemd, waarin o. a. de Nota's staan afgedrukt.

(b) Zie bl. 179 .

(c) Zie Bïdr. E. 215. 
gevolmachtigden, door de bepaling, dat men de schuld eerst tegen het einde van 1825 had te voldoen en zonder interest verschuldigd zou zijn. "Tegen thet einde van 1825", schreven zij aan Buitenlandsche Zaken, "zal men van Batavia niet alleen remises tot dekking van die uitgave ontvangen kunnen hebben, maar ook de zekere tijding, dat de gewigtigste bepalingen van het traktaat in OostIndie behoorlijk ten uitvoer zijn gebragt." Inmiddels zorgde de Bataviasche regeering er wel voor, dat van het zenden der remises geene quaestie zou zijn!

Aan al de in Nederland zeer juist gemaakte aanmerkingen over de redactie der artikelen kwamen de onderhandelaars mede tegemoet. De Billiton-bepaling van ontwerp-art. 14, in art. 11 van het tractaat overgaande, kreeg nu eene redactie, die, in verband met het volgend Singapore-artikel, den indruk moest maken, dat het eene tegen het andere opwoog. "Wij komen nu voor", schreven onze onderhandelaars over Singapore in zonderlinge woordenkeus aan Buitenlandsche Zaken, "van onze reclamatiën wegens de bezetting van dit laatste eiland af te zien, tengevolge van de bereidwilligheid der Engelschen om hunne aanspraak op Billiton te laten varen." De Singapore-bepaling van ontwerp-art. 15 in art. 12 van het tractaat veranderd wordende, onderging in zoover eene verbetering, dat op aanwijzing onzer gevolmachtigden, daarin tevens werd opgenomen eene geographische omschrijving der tot Djohor behoorende eilanden, op welke de Engelschen geen gezag of invloed zouden mogen uitoefenen. Elders heb ik verhaald tot welke zonderlinge, ergerlijke chicanes van Engelsche zijde ook al weer deze bepaling heeft geleid $(a)$; doch dit daargelaten; het is hier de plaats om juist ten aanzien der geographische omschrijving van het gebied der partijen op eene zeer hinderlijke leemte van het tractaat te wijzen.

Op zekeren dag kwam Falck voldaan van eene conferentie met de Engelsche gevolmachtigden terug, in welke goede stemming hij aan kapitein Elout, in tegenwoordigheid van amąnuensis Siccama vertelde, dat men het eindelijk over een groot beginsel eens was geworden, namelijk dat Nederland aan Engeland zoude afstaan alle bezittingen op de Vaste kust van Indië en Groot-Britannië zich daarentegen van de eilanden zou terugtrekken. Ter verduidelijking trok hij eene lijn op de kaart. - Wànneer dit heeft plaats gevonden en of het zich wel zoo toegedragen heeft, als verteld wordt, valt

(a) Zie Singapore II 410 vv.; ov. 98 vv. 
niet uit te maken, te minder, omdat, naar wij opmerkten, vau de Londensche besprekingen geene verbalen werden gehouden. Doch de heer Siccama heeft het vorenstaande eerst verhaald in 1858; hij alleen was toen nog van de Londensche commissie in leven $(a)$. De gewezen amanuensis verzekerde daarbij zich duidelijk te herinneren, dat deze lijn tennaastebij liep van Sumatra's noordelijke punt door de straat van Malakka onder Djohor om, verder noordwaarts. Falck zou tevens opgemerkt hebben, dit alzoo te verstaan was: dat wat boven de lijn lag aan Engeland, wat er beneden lag aan Nederland verblijven zoude. Beneden de lijn valt dus Borneo, had daarop Siccama gezegd, hetgeen Falck deed antwoorden: "Ja, maar wij zullen ons wel wachten om daarvan in het traktaat te spreken; de Engelsche Ministers zullen in het Parlement al moeite genoeg hebben, en mogt daar later kwestie over komen, dan zal het tijd genoeg zijn onze regten te laten gelden; voor het tegenwoordige is het ons genoeg, dat de Engelsche Staatslieden geene verdere uitbreiding wenschen van de bezittingen der O.-I. Compagnie en dat het hun ernst is om voor het vervolg alle aanleiding tot collisie tusschen de beide Gouvernementen eens vooral af te snijden."

Zoo werd over Borneo volstrekt gezwegen in het tractaat niet alleen, maar ook in de daartoe behoorende Nota's. De heer Siccama heeft deze weglating rationeel gevonden; althans hij merkt in zijn schrijven dd. 26 October 1858 nog op:

"Het zich geheel terugtrekken van Sumatra is een sterk bewijs voor de stelling, dat van de Engelsche zijde alstoen geenerlei vestiging meer bedoeld of wenschelijk geacht werd op de eilanden, waar Nederland reeds den voet gezet had. En Borneo was toen reeds, in 1824 immers? even als Sumatra op enkele punten door ons bezet. Dezelfde redenen dus, die er voor gepleit hadden om zich van dit laatste eiland terug te trekken, bestonden, en bestaan waarschijnlijk nog, voor de Engelschen om zich niet op het verder afgelegene Borneo te vestigen. Zij bezaten destijds in Borneo niets, en zoo was er dan ook voor hen geene reden om bij het traktaat dat land bij name te noemen. Ook indien zij zoo verre gingen om onzentwille, of liever op grond van hun beginsel, een eiland te verlaten, waar zij reeds bezittingen of althans betrekkingen hadden, dan spreekt het wel van zelve, dat zij het beginsel niet verloochenen

(a) Het medegedeelde kan men lezen in $B \ddot{j} d r . E .311$ vv. 
zoudeh met opzigt tot een land, waarin zij nog nimmer waren gevestigd geweest, gelijk Borneo."

Deze argumenteering is echter van geenerlei waarde. Het tractaat en zijne Nota's handelen over alles en nog wat; het volstrekt zwijgen over Borneo kon evenzeer uitgelegd worden, dat Engeland van deze bezitting niet wilde afzien. Mocht het er ook op het oogenblik der tractaatsluiting geene bezittingen hebben, het had ze er gehad en het had ze verlaten met de uitdrukkelijke mededeeling aan onze Commissarissen-Generaal, dat dit geenszins een volstrekt prijs geven van alle aanspraken op het eiland wilde zeggen $(a)$. Bovendien was door onze gevolmachtigden bij het afbreken der onderhandelingen van 1820 met zoovele woorden ontkend, dat wij naar een alléénbezit op het eiland streefden en het Londensch bestuur nam aanstonds van die verklaring goede nota, immers door aan de Bengaalsche regeering te schrijven, dat deze erkenning voor de toekomst als een "beginsel" van waarde kon zijn, m. a. w. een troef, die zoo noodig tegen Nederlandsche protesten uitgespeeld kon worden $(b)$.

Tegenover deze geschiedenis, waarvan onze gevolmachtigden zich hadden behooren te doordringen, mocht een volstrekt zwijgen over Borneo inderdaad onverantwoordelijk geacht worden, vooral nadat minister Elout er nog met een enkel woord de andacht op had gevestigd $(c)$; maar de geschiedenis van het Londensch tractaat van Maart 1824 is, ook ten aanzien van de bekwaamheid onzer diplomatie, die van kleiner Nederland.

\section{XIX.}

\section{De aanneming van het tractaat.}

Toen de gevolmachtigden van beide partijen zich over den vorm van het tractaat en van de daarbij behoorende nota's definitieff hadden verstaan, moest de Board of Control in de eerste dagen van Maart overgaan, berichtte Fagel den $5^{\mathrm{n}}$ dier maand aan Buitenlandsche Zaken, om het behandelde aan het Comité van Correspondentie der O. I. C. en vervolgens aan het volle college der bewindhebbers mede te deelen $(d)$. Immers tot dusver waren de

(a) Zie Bandjermasin 39-40.

(b) Zie Bandjermasin 73-74.

(c) Zie bl. 142 hiervóór.

(d) Zie den brief in Fagel's Ontslag 395 ; ov. 3. 
Britsche onderhandelaars slechts met het Geheime Comité der O. I. C. te rade gegaan, ten einde ontijdige publiciteit te voorkomen. Vandaar een schrijven dd. 6 Maart 1824 door den gèvolmachtigde, voorzitter van den Board of Control, gericht aan het "Special Secret Committee". Het stuk legt bijzonder gewicht op het belang der beloften door onze gevolmachtigden ten aanzien van Benkoelen gegeven $(a)$.

De aanneming van het tractaat door het bestuur der O. I. C. schijnt geene overwegende bezwaren te hebben opgeleverd. Reeds toch den $12^{\text {n }}$ Maart kon Fagel aan Buitenlandsche Zaken schrijven, dat de stukken nagenoeg ter teekening gereed waren $(b)$.

Den $17^{\mathrm{n}}$ had ook deze formaliteit plaats; denzelfden dag zonden onze gevolmachtigden de stukken naar Nederland voor de vereischte ratificatie. De aanbiedingsbrief hield eene schets in van hetgeen sinds de terugkomst van kapitein Elout was voorgevallen, wordende alzoo mede eene toelichting op het tractaat, waarvan ik reeds herhaaldelijk gebruik maakte (c). Dat minister Elout's af keurende nota's nog niet waren vergeten, bleek uit het slot van het stuk. "En met dit verslag", schreven namelijk de heeren, "beschouwen wij de eervolle doch moeijelijke taak, die ons was opgelegd, als voleindigd, niet zonder hope dat de tot stand gebragte schikkingen weldra bij de ondervinding blijken zullen bevorderlijk te zijn aan de veiligheid en welvaart van 's Konings 'nu geconcentreerde Bezittingen in Azie'. Onze grootste zoo wel als onze eerste belooning echter zoude het zijn te mogen vernemen, dat Z. M. over onze handelingen en over derzelver uitslag voldaan is en den pligtmatigen ijver erkent, met welken wij aan Hoogstdeszelfs vertrouwen hebben trachten te beantwoorden."

Kapitein Elout bracht den $19^{\text {en }}$ weder de stukken naar Nederland; minister Falck, door een aanval van jicht te Londen opgehouden, volgde spoedig $(d)$. Deze toch moest vóór hij zich aldaar als gezant ging vestigen, zijne particuliere zaken in orde maken en de

(a) Zie het stuk in Factorijen II, bijl. 10 Verg. Benkoelen 285; ov. 3.

(b) Zie den brief in Fagel's Ontslag 396; ov. 4.

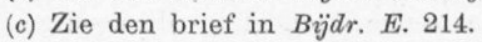

(d) „M. le Capitaine Elout part ce matin pour Harwich, et arrivera probablement à La Haye en même temps que la présente dépêche. Il est porteur du Traité que nous avons signé avant-hier. M. Falck s'est trouvé suffisamment remis d'un accès de goutte, dont il souffrait depuis quelques jours pour avoir pu se mettre en route hier dans l'intention de s'embarquer aujourd'hui à Dovres pour se rendre à Calais." Uit het in den tekst te vermelden rapport van Fagel dd. 19 Maart. 
portefeuille van Koloniën overgeven aan zijn opvolger, den heer Elout $(a)$.

Diens zoon had Londen reeds verlaten, toen Fagel van den secretaris van den Board of Control eene op 16 Maart gedagteekende nota van de Britsche gevolmachtigden ontving, waarbij zij, ingevolge art. 3 van het Tractaat, afschriften aanboden van de verdragen, die Engeland met inlandsche vorsten en volken in den Oost-Indischen archipel had gesloten $(b)$. Fagel haastte zich deze stukken bij missive aan Buitenlandsche Zaken dd. 19 Maart na te zenden $(c)$. Of onder de overgelegde verdragen ook behoorde de in 1818 gesloten overeenkomst met Siak, waarover later zooveel te doen zou zijn, is mij niet bekend $(d)$.

Aan het pakket, dat kapitein Elout had medegenomen, bleek bij aankomst te ontbreken, de tot het tractaat behoorende Nota der Nederlandsche gevolmachtigden. Op Buitenlandsche Zaken had men dit echter niet eens opgemerkt, zoodat de Koning er bij schrijven van 23 Maart door den secretaris van Staat aan het departement om moest laten vragen $(e)$ ! Men zond onmiddellijk eene herinnering

(a) Op een en ander heeft betrekking Falck's briefje uit Londen aan Elout dd. 8 Maart in Bijdr. E. 213. Verg. Fagel's Ontslag 396; ov. 4.

(b) ${ }_{n}$ The Undersigned Plenipotentiaries of His Majesty the King of Great Britain and Ireland, adverting to the third article of the proposed treaty between the two Powers, have the honour of communicating herewith to Their Excellencies the Plenipotentiaries of His Netherland Majesty copies of the several Treaties now in force, between the British Government, and Native Chiefs and States in the East-Indian Islands.

\section{George Canning}

Charles Watkin Williams Wynn. (B. Z.)

(c) „De heer kapitijn Elout was reeds vertrokken, toen mij, onder een bloot couvert, van wegens den heer secretaris Courtenay van het kollegie van den Board of Control toegekomen is, de in originalie hiernevens gaande Nota van de Britsche gevolmagtigden, gedagteekend den $16^{\text {den }}$ dezer. Dezelve is betrekkelijk de wederzijdsche mededeeling der tractaten, bij het $3^{\text {do }}$ art. van het zoo even geslotene tractaat bedongen, en zoo mijn geheugen mij niet bedriegt, zijn de daarbij vermelde overeenkomsten reeds eenigen tijd geleden aan ons medegedeeld, en, hetzij door ons overgezonden, of door den heer minister Falck in bewaring genomen. Zijne Excellentie zal waarschijnelijk in staat zijn deswegens aan UHoogEdelGestrenge, mondeling, de noodige inlichting te kunnen geven." (B. Z.)

(d) Verg. de breede Siak-correspondentie van 1828 in bijl. 11 van Atjeh.

(e) "Op last van Zijne Majesteit heb ik de eer aan het Departement van Buitenlandsche Zaken, weder te doen toekomen de aan Hoogstdenzelven voorgelegde stukken met betrekking tot het met Engeland gesloten tractaat over de Oost-Indische bezittingen en handel op dezelve.

„De Koning bij dezelve niet gevonden hebbende het in de missive der 
aan gezant Fagel, die, onder betuiging van zijn groot leedwezen, het vergeten stuk bij depêche dd. 26 Maart aan Buitenlandsche Zaken deed toekomen; het werd er den $31^{\mathrm{n}}$ ontvangen $(a)$.

Intusschen had reeds den $27^{\mathrm{n}}$ minister a. i. Reinhold eene op zijn departement ontworpen wet met "memorie ter adstructie" ingevolge 's Konings last gezonden aan minister Elout "met ootmoedig verzoek daarvan kennis te nemen, dezelve naar goedvinden te veranderen en te wijzigen, en ze mij vervolgens terug te zenden" (b). Verbazend ootmoedig dan toch! Welk eene aardige illustratie van de door De Grovestins gegeven karakteristiek over Reinhold: qui avait toujours l'air de vouloir s'excuser d'être monté si haut $(c)$.

Van Reinhold's werkstukken, bestemd voor onze Wetgevende Macht, nam ik kennis: zij waren geenszins gebrekkig; doch collega

Nederlandsche plenipotentiarissen van den 17 dezer $\mathrm{N}^{\circ} 10$, vermelde antwoord, hetwelk door hen gegeven is op de Engelsche ophelderende verklaringen, noch ook de in den brief van den baron Fagel van den 19 dezer bedoelde overeenkomsten, verlangt de nadere mededeeling dier stukken, zoodra dezelve bij het departement van Buitenlandsche Zaken zullen zijn ingekomen.

"Zijne Majesteit zal voorts de officiële inzending der nevensgaande documenten, vergezeld van de consideratiën en het advies van het Departement, te gemoet zien, terwijl ik overigens de eer heb het Departement van Buitenlandsche Zaken, op last des Konings, opmerkzaam te maken, dat volgens art. 58 der Grondwet, het tractaat aan de Staten-Generaal medegedeeld, en Hun Edelmogenden ter goedkeuring zal worden aangeboden. De Koning wenscht alzoo dat daartoe een ontwerp van wet, met eene memorie ter adstructie, in beide talen, in gereedheid en bij den Raad van Ministers in deliberatie worde gebragt." (B. Z.)

(a) „J'ai été fâché de voir par votre dépêche, $\mathrm{n}^{\circ} 10$, du 23 de ce mois, que parmi les pièces jointes à notre rapport du $17, \mathrm{n}^{\circ} 10$, accompagnant le traité signé ici ce jour là, et dont M. le capitaine Elout a été le porteur, ne s'est pas trouvée la copie (mentionnée dans le rapport) de notre Note en réponse à celle des Plénipotentiaires Britanniques. Comme je suis d'une grande exactitude dans ces sortes de choses, j'avais pris la veille du jour de l'expédition du paquet une peine toute particulière pour récapituler, à plus d'une reprise, avec le secrétaire May les différentes pièces qui devaient y être insérées. Le lendemain je crus pouvoir m'en rapporter à lui, et que tout était en règle à cet égard, et Mr. May lui-même partageait tellement cette dernière opinion, qu'encore aujourd'hui, quand je lui fis part de l'omission dont vous me donnez connaissance, il avait de la peine à se convaincre qu'elle eut eu lieu. Il faut bien cependant que cette omission ait été réelle, et j'ai l'honneur de vous transmettre la copie ci-incluse du document en question, me flattant, néanmoins, que vous aurez déjà pu en être mis en possession de quelqu'autre manière avant l'arrivée de celle-ci." (B. Z.)

(b) Zie den brief in Bijdr. E. 217-218.

(c) Zie Fagel's Ontslag 410; ov. 18. 
Elout oordeelde, den geest dier tijden huldigende, dat men voor de Staten-Generaal niet zoo uitvoerig moest zijn. Hij werkte dientengevolge het ontwerp van wet met de toelichting geheel om, waarna hij de stukken aan Falck liet lezeu. Deze verkoos ook Elout's ontwerp boven dat van Reinhold. "De herhaalde lezing der stukken heeft mij", luidde toch het antwoord van 3 April, "in het gevoelen bevestigd dat de wet volgens $u w$. project en dus kort behoort te zijn, en dat men zich bij de Memorie-adstructief liefst dient te bepalen tot hetgeen Hun Ed. Mog. aangaat, namelijk de oorbaarheid der ruiling en afstand" $(a)$. Elout schijnt zijn collega Reinhold, met het oog op de omwerking, verzocht te hebben om er over te komen praten; althans wij lezen een briefje van dezen $(b)$, geteekend "UE. ootm. dienaar", waarin de minister a. i. belooft zich naar Zijne Excellentie op het departement te zullen begeven, "schoon reeds vooraf overtuigd", voegt hij er ootmoedig an toe, "dat ik mij met haare denkbeelden en dus met het bewuste onderwerp $(c)$ volkomen vereenigen zal". $\mathrm{Nu}$, dat vereenvoudigde de zaak zeer.

Alzoo is de concept-wet met hare toelichting, die der StatenGeneraal in Mei 1824 werd aangeboden, het werk van Elout $(d)$.

De Memorie tot adstructie, zooals de toelichting heet, herinnert met enkele woorden aan het begin der onderhandelingen in 1820 ; aan art. 58 der Grondwet, die de tusschenkomst des wetgevers voor het tractaat vorderde; aan "de beste gezindheid tot eene vriendelijke afdoening", die bij partijen geheerscht had; en aan het nuttige der scheiding van beider gezag. Men zou van een en ander de overtuiging krijgen, werd betuigd, indien men het verdrag nauwkeurig las met "eenige verkregene kennis aan de Indische zaken en belangen"! Vervolgens gaat de Memorie in eenige bijzonderheden na, waartoe deze vriendelijkheid en kennis aan Indische zaken geleid hebben. Volgt de afstand van onze factorijen in Vóór-Indië; daaraan hadden we toch niets meer $(e)$. In Elout's oorspronkelijk ontwerp waren de factorijen specifiek genoemd, doch op Falck's bedenking in zijn briefje van 3 April: - "Ware het ook goed de kantoren der vaste kust in

(a) Zie het antwoord in Bïdr. E. 218 en in Falck's Brieven 259.

(b) In $B \ddot{j} d r$. E. 219.

(c) Onderwerp staat er; ik vermoed hier echter eene drukfout; geschreven zal wel zijn ontwerp.

(d) De toelichting is o. a. afgedrukt in Van Hogendorp's "Bijdragen" 2。 uitgave dl. V (9 $9^{\circ}$ en $10^{\circ}$ deel), bl. 242 en in De Waal's "Ned.-Indië in de Staten-Generaal", dl. I bl. 88.

(e) Zie de woorden in Factorijen II 472 ; ov. 188. 
de memorie adstructief met name te vermelden?" — is deze teekening van hetgeen wij eigenlijk in Vóór-Indië zouden verliezen, weggelaten, zoodat er nu enkel werd gesproken van de "gepastheid van den afstand van de Nederlandsche bezittingen op het vaste land van Indië". - Op dat vaste land lag tevens Malakka en niet ver ervan het eiland Singapore; maar aan het eerste hadden we eigenlijk ook niets meer, vooral nu we Singapore niet konden terugkoopen; dan was nu ons recht op Billiton erkend en kregen we mede het gezag over gansch Sumatra (a). - Alzoo kwam de Memorie tot het besluit, dat de afstand der bezittingen van de eene zijde alleszins opwoog tegen de aanwinst van de andere, "waarbij dan nog mag gevoegd worden", luidde het, "de vermindering, tot op eene som van 100.000 ponden sterling, van het hoog bedrag der Britsche vorderingen: hoezeer toch tegen deze vele naamwaardige vorderingen van den Nederlandschen kant zijn ingebragt, zoo zou bij eene meer ontwikkelde berekening van beider schulden en aanspraken de opoffering, die ten deze ten laste van de Overzeesche bezittingen komen zal, het nu bepaalde hebben overtroffen". - Falck vroeg mede in zijn briefje "of men op het slot wel gewag moet maken van de pecuniële vorderingen en verminderingen onzer schuld tot 100.000 pd. st." ; ter nadere toelichting waarvan hij opmerkte: "De Times heeft reeds het harnas tegen het traktaat aangetrokken en de Engelsche Ministers verweten, dat zij zich door ons in de luijeren hebben laten leggen. I $\mathrm{k}$ weet dat een ieder zijne eigene baan schoon houden moet; maar de loyauteit vordert echter dat wij zorg dragen van niet door breede uitmeting der bedongen voordeelen de vrienden van Raffles en de opposanten in het algemeen, wapenen in de hand te geven, met welke zij het Canning c.s. al te lastig zouden kunnen maken." Aan dezen wenk werd echter geen gevolg gegeven; men maakte het Canning c. s. ook niet al te lastig; aan de overzijde van het Kanaal wist men wel tractaten te lezen.

De gedachtenwisseling in de afdeelingen onzer Vertegenwoordiging leidde den $24^{\mathrm{n}}$ Mei tot een pover verslagje, met eene niets met het tractaat uitstaande opmerking over de gelijkstelling door de Britsche wetgeving van slavenhandel met zeerooverij en nog ééne enkele andere over - typische belangstelling! - de 100.000 pd. st. "De meeste afdeelingen", leest men namelijk, "hebben volstrekt geene aanmerkingen gemaakt. Eenige afdeelingen hebben verlangd

(a) Zie de woorden in Singapore II 392-393; ov. 80-81. 
de zekerheid te bekomen, dat de 100.000 pd. st., welke, volgens art. 16, aan Engeland moeten betaald worden, geheel ten laste van de Indische bezittingen komen zullen. Het gouvernement heeft geantwoord, dat men zich hieromtrent kan gedragen aan de memorie van toelichting, welke andere afdeelingen juist gevat hebben, gelijk zij dan ook hun genoegen over de alzoo verkregene zekerheid hebben te kennen gegeven" $(a)$.

Den $25^{\text {en }}$ Mei hadden de openbare beraadslagingen plaats; slechts de heeren Beelaerts van Blokland en Van Alphen voerden het woord (b).

De eerste wees ten onrechte op het geringe belang van ons verlies in Hindostan $(c)$; vervolgens onderschatte hij evenzeer de waarde van onzen afstand van Malakka, doch beschuldigde hij welverdiend het Nederlandsche regeeringsbeleid in zake de bezetting van Singapore $(d)$; juichte daarna toe onze verkrijging der Britsche bezittingen op Sumatra en de erkenning van ons recht op Billiton $(e)$; bracht ter loops in herinnering nevens de vrijzinnige handelsbeginselen van het tractaat, onze verplichting tot het betalen van f 1.200.000, waarbij de spreker zich tot echo der Regeering maakte, voor zoover deze had medegedeeld, dat we blijde mochten zijn er nog zoo goedkoop af te komen $(f)$; om te besluiten met een

(a) Het verslagje op bl. 244 van de in noot $d$ bl. 190 aangehaalde Bïdragen van Van Hogendorp.

(b) De redevoeringen bij De Waal t. a. p. 90-95.

(c) Zie de woorden bij Factorijen II 472-473; ov. 188-189.

(d) Zie de woorden in Singapore II 393-394; ov. 81-82.

(e) "Wanneer wij nu deze ruiling verder onderzoeken, zoo vinden wij, dat voor hetgeen wij afstaan, door ons verkregen wordt het fort Marlborough, met alle de Engelsche bezittingen op het eiland Sumatra. Dit mogen wij van veel belang achten, zoo uithoofde dat daardoor menige grond van verschil, van twist, van jaloezij, van gegronde of ongegronde achterdocht, is weggenomen, als omdat ons gezag, ten aanzien van inlandsche vorsten en volken van dat eiland, te beter bevestigd en als het ware de stempel op onzen te Palembang betoonden moed en behaalde overwinning wordt gedrukt, terwijl de vruchten van dit onverdeeld bezit van Sumatra eerst in volgende tijden zullen kunnen worden ingeoogst, wanneer Nederlandsche nijverheid en Nederlandsche regtvaardigheid in bestuur er de zaden toe zullen hebben gestrooid. Verder verkrijgen wij het rustig bezit van het eiland Billiton, dat ons (al was het dan slechts met weinig grond van regt) betwist werd, omdat het niet letterlijk bij het verdrag van 1814 onder den afstand van Banka was begrepen; maar het is daarom belangrijk, omdat nu het bezit van laatstgemeld eiland meerdere waarde verkrijgt."

(f) "Van de schuld van 100.000 pd. st., die wij aannemen te voldoen, zal ik niet spreken, zoo omdat die som niet is een saldo van ruiling van grondgebied en dus met die ruiling of afstand in geen direct verband staat, als 
weliswaar niets afdoend en ook eigenlijk bij het tractaat niet behoorend protest tegen het verlies van de Kaap de Goede Hoop, doch waarvan de vermelding niettemin in den tegenwoordigen tijd geenszins van belang ontbloot geacht mag worden. Ziehier wat hij zeide :

"Hoe gaarne, Ed. Mog. Heeren, had ik in dit traktaat van wederzijdschen afstand en ruiling een ander voorwerp aangetroffen, ik bedoel de Kaap de Goede Hoop. Deze volkplanting, door Nederlandschen ondernemingsgeest vóór meer dan anderhalve eeuw aangelegd, eerst als eene bloote ververschingsplats, vervolgens door Nederlandsche nijverheid en gastvrijheid uitgebreid, in het laatst der $17^{\text {de }}$ eeuw de schuilplaats geworden van een groot aantal Fransche vlugtelingen, die, uithoofde van vervolgingen om de Godsdienst, hun vaderland moesten verlaten, en welke hunne kennis van landbouw, wijnteelt of andere bedrijven naar den zuidelijken hoek van Afrika hebben overgebragt: deze volkplanting geleek meer naar eene Nederlandsche provincie, dan eenige onzer andere buitenlandsche bezittingen. In bevolking, in taal, in zeden, in wetten, in gewoonten, meer Europisch dan Indisch, meer Nederlandsch dan vreemd, is zij ook (dit durf ik verzekeren) meer gehecht aan Nederland dan aan eenige andere Mogendheid. Dat heb ik gezien gedurende den geheelen tijd van mijn verblijf aldaar; dat heb ik gezien in het jaar 1811, toen de inlijving van Holland in het Fransche Keizerrijk aldaar bekend werd, en een vertoog aan de Regering van Groot-Brittannië geteekend werd, met welks inlevering, uit naam der aanzienlijkste Kaapsche ingezetenen, ik mij heb belast gevonden, bij hetwelk zij verzochten, dat die volkplanting als de schuilplaats mogt worden bestemd voor die Nederlanders, die hun ongelukkig uit den rang der volkeren uitgeschrapte vaderland mogten willen verlaten; dit heb ik gezien in 1814, toen de tijding der bevrijding van Nederland het gevoel der Zuid-Afrikanen in geestdrift deed ontvlammen, omdat zij uit die gebeurtenis de hereeniging met hun oude moederland voorspelde; en ik heb het eindelijk gezien in 1815 , toen de blijde tijding der overwinning van Waterloo,

omdat zij behoort tot - en het bij schikking bepaalde saldo vitmaakt van de Indische likwidatie van wederzijdsche vorderingen, welke, tot den laatsten penning berekend, welligt een hooger saldo ten onzen laste zouden hebben doen ontstaan; terwijl deze bepaalde som (dat verzekert ons de ophelderende memorie) uit onze Indische bezittingen zal worden betaald, en dus geen post op de begrooting van 's Rijks uitgaven zal uitmaken. Het traktaat bevat overigens zeer billijke vrije beginselen op handel en scheepvaart."

$7^{\circ}$ Volgr. II. 
door het tegelijk aangekomen berigt van de te Londen gesloten overeenkomst, zoo droevig werd getemperd, en de afstand der volkplanting aan Groot-Brittannië smart, vertwijfeling, verslagenheid veroorzaakte. Ware het mogelijk geweest deze voormalige Nederlandsche, zoo weinig gekende, bij velen miskende bezitting te begrijpen in de ruiling, die ons thans wordt aangeboden, zoo zoude men niet alleen een land, naar een onzer provinciën gelijkende, weder in onzen schoot hebben opgenomen, maar ook aan eene bevolking van omtrent 100.000 zielen, meest Nederlandsche afstammelingen, een groot genoegen hebben bewezen, en voor onzen handel en scheepvaart een nieuw leven, nieuw voedsel en voordeelen verkregen, die rijkelijk konden opwegen tegen de kosten, welke het onderhouden eener krijgsmagt aldaar mogt veroorzaken. Ik zeg opzettelijk de kosten eener krijgsmagt, omdat het buiten tegenspraak is, dat het civiele bestuur van die kolonie uit hare eigene inkomsten volkomen kan worden bekostigd, ja daarop een overschot worden uitgewonnen, toereikend tot de inlandsche verdediging. In meerdere bijzonderheden mag ik thans niet treden; ik moet reeds verschooning voor dezen uitstap vragen, denzelven besluitende met den wensch, dat eenmaal de omstandigheden ons het bezit van deze volkplanting mogen wedergeven. Met nog meerdere voldoening zoude ik dan mijne stem uitbrengen tot bekrachtiging van eeu traktaat, dat zulke uitkomsten aanbood, dan ik nu doe tot goedkeuring van het onderhavige."

Ook Van Alphen juichte de in het staatsstuk nedergelegde beginselen toe, waar het eene scheiding der bezittingen van partijen tot stand bracht; in de verkrijging van gansch Sumatra verheugde hij zich mede; in het verlies van Malakka meende hij te moeten berusten, al ware het met leedwezen $(a)$; eindelijk deed hij een goed woord voor de ondersteuning en aanmoediging van "de individuele nationale ondernemingen".

Het tractaat werd met algemeene stemmen aangenomen; het is geworden de wet van 18 Juni 1824, die werd afgekondigd in het Nederlandsch Staatsblad van 1824 $\mathrm{N}^{\circ}$ 39. De Indische regeering kondigde eerst het tractaat af dd. 19 April 1825 Indisch Staatsblad $\mathrm{N}^{\circ} 19$, zonder den sacramenteelen aanhef der wet. "Alzoo", luidde de overweging der Publicatie, "aan Ons, van wege Zijne Majesteit den Koning is toegezonden, een authentiek afschrift van het tusschen

(a) Zie de woorden in Singapore II 393 ; ov. 81 . 
de Gevolmagtigden van Hoogstgemelde Zijne Majesteit, en die van Zijne Majesteit den Koning van Groot-Brittanje, op den $17^{\text {den }}$ Maart 1824, te Londen gesloten Traktaat, luidende als volgt".

In het Britsche parlement had men den $17^{\mathrm{n}}$ Juni 1824 eene levendige gedachtenwisseling over het tractaat gehad $(a)$. Opmerkelijk was het, wat minister Canning zeide over de geringe waarde van.... Benkoelen. Canning betoogde nader, dat het "zeer verstandig zou zijn geweest", indien Engeland deze nederzetting "geheel zonder eenige schadeloosstelling" had verlaten. Zoo werd nu gesproken over eene bezitting, die men niet tegen onze Factorijen in Hindostan had willen overdoen $(b)$; maar Falck zal zich er wel niet aan geërgerd hebben, op den door hemzelven aangevoerden grond, dat een ieder zijne eigen baan tracht schoon te vegen. Trouwens, toen eenmaal Benkoelen in ons bezit was en wij de gelegenheden hadden gehad, er de zaken behoorlijk op te nemen, scheen het mede te vallen, ten minste luitenant-gouverneur-generaal De Kock schreef dd. 4 Juni 1825 aan het lid in den Raad van Indië Mr. H. J. van de Graaff : "UHEdG. zal zeker met genoegen uit de stukken ontwaren, dat de vooruitzigten ten aanzien van Bencoelen niet zoo ongunstig zijn, als men eerst had moeten gelooven, en het komt mij wenschelijk voor om de Pepercultuur aan te moedigen" $(c)$.

XX.

\section{De instructiën ter uitvoering van het tractaat van} 17 Maart 1824.

Bij missive dd. 31 Augustus 1824 zond minister Elout, die, naar wij weten, den $1^{\mathrm{n}}$ April 1824 departementschef van Koloniën was geworden, een authentiek afschrift van het tractaat aan de Indische regeering, hetwelk te Batavia werd ontvangen in de eerste dagen van Januari 1825; de brief bevatte breede instructieve aanwijzingen, in het belang eener geleidelijke en spoedige uitvoering van de gesloten verbintenis $(d)$.

(a) Men kan ze vinden bij Parvé 8:2 vv.

(b) Zie Factorïen II 464; ov. 180.

(c) Van de Graaff I 239 No 136.

(d) Onder het eenigszins vreemde hoofd Instructiën voor den GouverneurGeneraal van Nederlandsch-Indië is de depêche van 31 Augustus 1824 opgenomen in Bijdr. E. 239-248 met de verkeerde aanwijzing van de maand Juli en verder zonder aanwijzing van den dag. 
Ook het Engelsch bestuur gaf natuurlijk de noodige bevelen; maar het deed dit anders en, naar men zou zeggen, beter. Toen toch het tractaat op den $17^{\mathrm{n}}$ Maart 1824 gereed was, zond het onverwijld, dus toen er nog de ratificatiën en de goedkeuring der wetgevers aan ontbraken, bij missive van den $20^{\mathrm{n}}$ Maart geheime instructiën naar Bengalen, ten einde over hetgeen stond te gebeuren, inlichtingen te verstrekken $(a)$. Wij gaven evenzeer eene voorloopige mededeeling, doch met de nachtschuit, d.i. een kwartjaar $n a$ de sluiting, immers dd. 21 Juni (b)! En dat de Britsch-Indische ambtenaren het geheim der mededeeling van 20 Maart 1824 goed hebben bewaard, bewijst Van der Capellen's particulier schrijven dd. 21 Februari 1825, waarin hij naar aanleiding der depêche van 31 Augustus 1824 . o. a. opmerkt: "Volgens de laatste berigten uit Bengalen waren daar hoegenaamd geene officiële tijdingen of instructiën betreffende het gesloten traktaat aangekomen, zoodat wij waarschijnlijk in de voorbaat zullen zijn" $(c)$. In de voorbaat! Maar reeds in September 1824 waren de dagbladen lezende bewoners van Britsch-Indië in de gelegenheid gesteld geworden van het eerst in Juni te voren door den Engelschen wetgever aangenomen tractaat kennis te nemen $(d)$ !

De daarop gevolgde Engelsche instructie was ook é́ne maand vóór de Nederlandsche vastgesteld; immers reeds den $4^{\mathrm{n}}$ Augustus 1824. Neemt men bij dat alles in aanmerking het meer omslachtige van een Compagnie's bestuur, dan steekt ook in dit opzicht de Britsche voortvarendheid bijzonder gunstig bij onze wijze van doen af. Onderscheidene voorschriften van deze correspondentie zijn voor onze koloniale geschiedenis van belang; op het gewicht er van wees ik trouwens in vroegere verhandelingen $(e)$.

De indruk, dien het tractaat in Nederlandsch-Indië maakte, was van diep teleurstellenden aard; het kon echter nu niet anders zijn dan een vruchteloos napleiten, dat voor zoover Van der Capellen er aan mede deed, slechts moest strekken, om de reeds niet normale verhoudingen tusschen hem en Elout te verergeren $(f)$. Overigens ging het met de overneming door ons van de door Engeland afge-

(a) Bijl. 11 van Factorijen II.

(b) Factorïen II 473; ov. 189.

(c) Bïjr. E. 251.

(d) Factorijen II 475; ov. 191.

(e) De correspondentie is opgenomen, in bijl. 25, met noten waarin naar die verhandelingen wordt verwezen.

(f) Singapore II 397-403; ov. 85-91. 
stane bezittingen even weinig voortvarend als met het toezenden der instructiën. Het op het tractaat betrekkelijk Indisch besluit was gedagteekend 6 Februari 1825, doch dit liep over onze overgave van Malakka en de factorijen in Vór-Indië; art. 6 toch bepaalde, dat, wat betrof onze bezitneming van de Engelsche bezittingen ter Sumatra's Westkust, moest gewacht worden "totdat van het Militair departement zal zijn ontvangen een voorstel omtrent de militaire magt, tot dit einde te verzamelen en de middelen om die op Benkoelen bijeen te brengen" $(a)$. Wij hadden namelijk geene schepen, en al waren ze voorhanden geweest, dan zouden we er toch geen gebruik van gemaakt hebben, wegens gemis aan troepen! "Dat bij dit zelfde besluit", schreef de landvoogd aan den minister over het stuk van 6 Februari, "geene bepalingen werden gemaakt omtrent de overneming van de Britsche bezittingen op Sumatra, moet worden toegeschreven daaraan, dat het toen voorhanden schip geene bekwame gelegenheid tot correspondentie met Padang aanbood (van waar deze overneming moet worden bestuurd) en wijders dat het Militair departement nog geene middelen had kunnen beramen, tot het bijeenbrengen der noodige troepen, voor de bezetting van Benkoelen en onderhoorigheden vereischt, voor welker transport van Java naar Sumatra evenmin op dat oogenblik eenige mogelijkheid bestond. Toen echter Zijner Majesteits korvet Dolphïn weinige dagen later van Palembang op de reede van Batavia kwam, besloot ik ook onverwijld hiertoe de vereischte bevelen uit te vaardigen, en hoezeer de op Java voorkomende en disponibele magt reeds uitermate verzwakt was, eene buitengewone poging te doen, ten einde ook in dit opzigt, voor zoover van mij kan afhangen, wierd beantwoord aan Zijner Majesteits last." - Aan den gouverneurgeneraal van Bengalen werd ook een brief, namelijk dd. 7 Februari over deze aangelegenheid door Van der Capellen geschreven, maar in stede van te reppen over het gemis aan scheepsgelegenheid en aan troepen, werd de schuld der vertraagde behandeling geworpen op den slechten moesson. "Je m'occupe déjà", verzekerde namelijk onze Landvoogd: "de préparer tout ce qui devra précéder la remise des dépendances du fort Marlborough, par les autorités Britanniques. Toutefois l'impossibilité d'y transporter incessamment dans cette mousson les troupes nécessaires pour relever ce poste m'empêche de procéder dans cette affaire aussi promptement que je le désirerais.

(a) Het besluit in bijl. 12 van Factorijen II. 
J'espère cependant trouver bientôt les moyens d'obvier à cet inconvénient et je m'empresserai de faire part à Votre Excellence des mésures ultérieures que je serai dans le cas de prendre pour l'exécution pleine et entière de la convention conclue par nos cours en Europe" $(a)$. Tien dagen later kon de landvoogd melden, dat de Dolphïn naar Sumatra's Westkust zou zeilen. Toen, dus den $17^{\mathrm{n}}$ Februari, werd ook de overneming van Benkoelen bevolen. Had de landvoogd eerst dd. 28 Februari mededeeling aan den minister gedaan: én van de redenen, waarom niet vroeger dan den $6^{\mathrm{n}}$ te voren het noodige was besloten voor onze overgave van Malakka benevens van de Vóór-Indische factorijen (b); én waarom buiten dat besluit van den $6^{\mathrm{n}}$ Sumatra's Westkust had gelaten moeten worden, gelijk hierboven aangegeven; - hij berichtte tevens, dat met deze dubbele mededeeling tot den $28^{\mathrm{n}}$ was gewacht, omdat er prijs op werd gesteld tegelijkertijd van de besloten maatregelen voor Sumatra te kunnen gewag maken $(c)$. Toch ging nog de gansche maand Maart voorbij, alvorens aan de overneming van de Engelsche bezittingen op Sumatra's Westkust kon begonmen worden, tot niet geringe ergernis van de Britsch-Indische autoriteiten $(d)$. Natuurlijk, dat het geen geheim bleef, waarin de moeilijkheid had bestaan. Als dan ook de archivaris van het Londensch koloniaal archief, F. C. Danvers, in een door The Asiatic Quarterly Review gepubliceerd rapport over "The English connection with Sumatra" herinnert aan al. 1 art. 13, volgens welke de overnemingen moesten hebben plaats gevonden op 1 Maart 1825, merkt hij ten aanzien van onze verschijning te Benkoelen op: "No one, however then arrived to take possession, the Dutch being so much engaged in hostilities in their Eastern possessions, that they had not sufficient troops to spare for the occupation of the several stations, they were to receive possession of" (e).

Met het in werking treden van het tractaat, had de Indische regeering terstond te letten op art. 2, volgens welk de douanetarieven niet hooger voor de Engelschen mochten zijn dan het dubbele, van de Nederlandsche schepen en onderdanen te heffen,

(a) Uit het archief van Koloniën.

(b) Zie Factorijen II 475; ov. 191.

(c) Zie noot $b$ in Factorijen II 507; ov. 223.

(d) Zie Benkoelen 286-287; ov. 4-5.

(e) Zie jaargang 1886, bl. 431. Ook afzonderlijk uitgegeven in een: Report to the Secretary of State for India in Council on the records of the India Office: Vol. I Part 1 (1887), bl. 83. 
terwijl een maximum van 6 pCt. der waarde gesteld werd, wanneer van eigen nationaliteit geene rechten werden geheven. De minister had in zijn instructief schrijven van 31 Augustus 1824 ten deze opgemerkt: "Voor zoo ver hier bekend is, zijn de regten, welke in Nederlandsch-Indië van Britsche schepen geheven worden, of beneden òf op het peil van deze overeenkomst. Mogt evenwel bij verordening een grooter onderscheid tusschen de Britsche en Nederlandsche vlag bestaan dan het traktaat toelaat, zoo zal U Ex. onverwijld de noodige maatregelen nemen, waardoor die regten tot het nu overeengekomen bedrag worden verminderd $(a)$ ". - Er bestond inderdaad grooter onderscheid. Zoo was er een uitgaand recht op vervoer door vreemden van koffie naar vreemde havens ad f 5 per pikol, terwijl slechts $\mathrm{f} 2$ voor de eigen vlag werd gevorderd $(b)$. Had de minister echter gelast, dat dan het hoogere recht verminderd moest worden, dus op $\mathrm{f} 4$, de Indische regeering achtte het daarentegen beter, omgekeerd het lagere tarief te verhoogen, dus tot $f 2 \frac{1}{2}$ op te voeren $(c)$ : "omdat door de vermindering", berichtte de depêche van 28 Februari 1825, "'s lands inkomsten ongevergd eene niet onbeduidende reductie zouden ondervinden eeniglijk ten behoeve van de vreemde scheepvaart, terwijl de verhooging voor de Nederlandsche vlag, werkelijk slechts nominaal is en niet met de daad bestaat; want er is tot dus ver nog geen voorbeeld van nitvoer van koffij onder Hollandsche vlag naar eene vreemde haven en de omstandigheid, waarin de nu bevolene verhooging door de Nederlandsche vlag zal moeten worden betaald, heeft zich dus nog niet opgedaan, noch is het te voorzien, dat zich die spoedig of dikwijls zal aanbieden". Ook beval zich deze regeling aan, omdat anders de aanmoediging tot vervoer der koffie door vreemden naar Nederland verloren ging; immers daarvoor hadden zij nu te Batavia te betalen $\mathrm{f} 3$, terwijl bij aankomst in Nederland $\mathrm{f} 1$ moest opgebracht worden; bij verlaging van de $\mathrm{f} 5$ tot $\mathrm{f} 4$ uitvoerrecht hadden vreemden geene aan het tarief te ontleenen reden meer om naar Nederlandsche havens te stevenen.

Met betrekking tot het geval van geene rechten voor de Nederlandsche vlag, bestond er voor vreemden een recht van $12 \mathrm{pCt}$. $(d)$. De

(a) B̈̈jdr. E. 240.

(b) Zie Stbl. $1823 \mathrm{~N}^{\circ} 27$ en art. 22 van Stbl. $1818 \mathrm{~N}^{\circ} 58$.

(c) Zie Stbl. 1825 No 8 art. 1.

(d) Stbl. $1822 \mathrm{~N}^{\circ} 30^{\mathrm{a}}$. 
Indische regeering verlaagde dat tot $6 \mathrm{pCt}$. (a), en wel nu voor alle vreemde natiën. Zij toch waren gewoon op gelijken voet te worden behandeld; een voorschrift enkel voor de Britsche vlag zou slechts tot hinderlijke reclames leiden, meende de landvoogd. "Mogt Zijne Majesteit daarin verandering begeeren", luidde de depêche, "dan kan zulks gevoegelijk later geschieden, na eene grondige beschouwing der vraag of het wel immer in ons wel begrepen belang zoude kunnen zijn, aan den Britschen handel in de Indische zeeën, die door deszelfs stapelartikelen, de lijnwaden en de opium, bereids zoo veel voor heeft in de mededinging met alle andere natiën, nog door eene verligting van regten op onze eigene markten een nieuw voorregt toe te leggen, boven de overige bevriende mogendheden, die in Indië bij ons ten handel komen." - Deze onvriendelijke opmerking aan het adres van het Nederlandsche regeeringsbeleid besloot met een P.S., waarin andermaal werd herinnerd welk een slechten ruil wij deden door Malakka aan de Engelsche factorijen op Sumatra ten offer te brengen $(b)$.

Het tractaat was eene schitterende overwinning voor Raffles' drijven in den Oost-Indischen archipel geweest. Dat wij hem er gelukkig mede zouden zien, liet zich begrijpen; minder dat zijne tevredenheid ook eene bron van voldoening werd voor den man, die onzen koloniën zoo weinig ten goede is geweest, onzen Londenschen gemachtigde Mr. A. R. Falck $(c)$. — Zijne voldoening over het volbrachte werk sprak Falck mede uit in een schrijven dd. 7 April 1824, gericht aan den raadgever, door wiens toedoen vooral wij klakkeloos Singapore hebben prijsgegeven, den schout-bij-nacht Wolterbeek $(d)$. Zijn dagboek en al de daarbij behoorende papieren had hij aan Falck ter lezing gegeven, diezelfde stukken, waarvan ik zoo'n ruim gebruik heb gemaakt, gelijk de lezer der Bijdragen van het Instituut zich zal herinneren. Den schout-bij-nacht er voor bedankende, schreef Falck: "Ongesteld uit Engeland vertrokken en geheel ziek alhier aangekomen, heb ik mijn voornemen niet ten uitvoer kunnen brengen van UHgEdG. onder de allereersten, met den inhoud bekend te maken van het op den 17 Maart jl. gesloten koloniaal tractaat. $\mathrm{U}$ zal dus nu reeds uit de nieuwspapieren gebleken zijn, waar het op nederkomt, doch wil ik mij zelven

(a) Zie art. 22 van Stbl. $1825 \mathrm{~N}^{\circ} 8$.

(b) Zie Singapore II 401; ov. 89.

(c) Atjeh 210; ov. 52.

(d) Verg. Singapore I 413; ov. 25. 
echter het genoegen niet ontzeggen van $\mathrm{u}$ te doen weten, dat het journaal en andere belangrijke papieren, die ik twee jaar geleden van u ter leen ontving, grootelijk bijgedragen hebben om mij een, zoo ik vertrouw, juist denkbeeld te geven van de punten, die het voornamelijk zaak was te bedingen. - Sumatra is eens voor al aan den Engelschen invloed onttrokken en geheel en al binnen den werkingskreits geplaatst van de Nederlandsche staatkunde. Ons regt op Billiton is erkend en Rhio en al de Djohorsche eilanden, met uitzondering van Sinkapoor, blijven onze voorposten aan die zijde. Voor UEd. behoeft niet te worden betoogd, dat, in vergelijking van dit een en ander, de afstand van Malakka eene onbeduidende opoffering is. De kantoren op de Vaste Kust zijn in compensatie gekomen van Engelands pecuniële vorderingen. Voorts twijfel ik niet of UEd. zal insgelijks de wijze goedkeuren, waarop men het opkomen van nieuwe geschillen tusschen de respectieve agenten heeft trachten onmogelijk te maken; doch zulks te ontwikkelen, laat mijn tegenwoordig bestek niet toe. In Mei wordt het tractaat, met twee explicatoire nota's, aan de Staten-Generaal medegedeeld." - Op de mede in dezen brief gedane vraag, wat met de geleende stukken moest gedaan worden, ' zijn deze bij het ministerie van Marine bezorgd, waaruit zij later, dank minister H. Dyserinck, bij 's Rijks archief te 's-Gravenhage overgingen $(a)$.

(a) Zie Sumatra's Westkust II noot 64 , op bl. 269 ; ov. 65 . 


\section{B IJ L A G E N}

BEHOORENDE BIJ

\section{"De geschiedenis van het Londenseh tractaat van 17 Maart 1824"} DOOR P. H. VAN DER KEMP.

Bijl. 1. bl. 51 noot $b$. De brief dd. 19 October 1819 van den Minister van B. Z. aan dien van Koloniën luidt aldus (B. Z.):

Het is Uwe Excellentie bekend, dat de Koning aangenomen heeft om tegen de maand November aanstaande met het Hof van Groot-Brittaniën in minnelijke negociatie te komen over de O. I. zaken.

Deze tijd op handen zijnde, zal het noodzakelijk worden bedacht te zijn op de voorschriften, die gegeven zullen behooren te worden aan de Commissie aan welke van wege Z. M. zal worden opgedragen, om met de Britsche plenipotentiarissen over het uit den weg ruimen der quaestieuze voorwerpen in onderhandeling te treden.

Diensvolgens heb ik de eer Uwe Excellentie met voorkennis van den Koning uit te noodigen, om mij, zoodra mogelijk, in den vorm eener instructie, de punten te doen kennen, waarnaar zich de Nederlandsche commissie zoude dienen te gedragen.

Te gelijker tijd neem ik deze gelegenheid waar om Uwe Excellentie in bedenking te geven of niet de heer Elout, gewezen commissaris-generaal op het eiland Java, aan Z. M. zoude kunnen worden voorgesteld als de geschiktste persoon, om met en benevens den Heere Ambassadeur Fagel, die reeds vroeger door den Koning is gedesigneerd, dit werk van de Nederlandsche zijde te behandelen.

Bijl. 2. bl. 58 noot $a$. Brief dd. 17 Juli 1819 van de regeering te Calcutta aan de directie der Compagnie te Londen (B) (a):

By the "Atlas" and the «Streatham" we have had the honor of receiving your letters of the 3 oth October and the $27^{\text {th }}$ January, relating to the proceedings of the Dutch and sir T. S. Raffles in the Eastern seas.

(a) Het antwoord uit Londen op dezen brief vindt men in bijl. 56 Singapore I. 
2. The numerous communications, which we have had occasion to address to your Honorable Committee on particular parts of this subject will have made you fully informed, as well of the conduct and pretensions of the Dutch in the Eastern seas, as of our sentiments and proceedings.

3. We conceived that your Honorable Committee cannot fail to remark that the views of the Dutch, are, to all appearance, boundless; and that whilst your instructions to your Government in India enjoin moderation and forebearance, those which the Netherlandish authorities receive from their own Government must, to justify their proceedings, be of a very opposite nature.

4. Hence your Honorable Committee will no doubt, see the necessity of urging His Majesty's ministers to settle definitely in Europe the relations and power of the two nations in the Eastern seas, for until these points be defined, we foresee endless disputes likely to arise between the local Governments, from measures of aggrandizement and encouragement on the part of the Dutch, and counteracting measures of precaution on our part, unless it be your pleasure that we should submit implicitly to the establishment of their exclusive supremacy over the Eastern archipelago, without any effort on our part to preserve a share of those seas.

5. Since we last addressed you on this subject, we have received from the Dutch Governor-General a remonstrance on the occupation of Singapore, of which and of our reply we have now the honor to transmit copies $(a)$.

6. Your Honorable Committee will remark that in our reply to Baron Van der Capellen, we have assumed as the interpretation of the convention of August 1814 , that we only restored to the Sovereign of the Netherlands those territories or establishments of which the Dutch, having been in possession in 1803 , had been deprived by us in war.

7. With respect to possessions formerly held and voluntarily relinquished by them, without ever coming into our occupation by conquest or transfer, it appears to us, that their rights, though not affected either by the war or the treaty, are either nullified by abandonment or rendered obsolete by disuse; and in such cases, where they seek to form a new establishment, we do not hold ourselves bound to acknowledge any pre-existing right, but rather view the transaction as a novel case on which we are at liberty to regulate our conduct

(a) Zie deze beide stukken sub 50 en 52 Singapore I. 
by an equitable regard for our own interests, combined with due attention to the established law of nations.

8. The Dutch authorities, on the other hand, whenever they can find such a plea, pretend to found their claim on ancient relations, but at the same time, betray their sense of the valibility of such claims, by exacting new treaties from the native princes; and take advantage of new treaties to establish powers, to which they, never before, had a title.

9. The unlimited nature of their pretentions, sufficiently indicated by the general tone of their proceedings, is more precisely manifested in two instances. Their agent at Pontiana warned major Farquhar, at that time the envoy of the Government of Prince of Wales Island, not to enter into any negociations with any of the chiefs of Borneo, as the whole of that immense territory had come under the Dutch supremacy. Such was the assumed result of establishing one, or two, or three posts on the sea-coast of Borneo (a). Again, in consequence of a treaty made with the local Government of Rhio, similar pretentions are asserted over the whole of the ancient empire of Johore, Lingin, Rhio and Pahang; though it appears clearly that there is now little connection between the several parts of that ancient empire, and that the legal government of Rhio, acting in the name of a chief at a distance, whom it does not consult, would be but a subordinate part of the united government, if such were an efficient existence $(b)$.

IO. If such immense pretensions, resting on fondations so loose and arbitrary, are to be implicitly submitted to, where is the port in the Eastern seas, beyond those which we actually occupy, into which British vessels will be allowed an entrance, except under the permission of the Dutch, attended by such restrictions as they may think fit to impose for the purpose of shackling our commerce, or securing their own monopoly?

II. We have been led to submit these remarks by an anxious desire to draw the serious attention of your Honorable Committee to this subject. It is in Europe that all these questions must be determined, and we think it our duty to represent to your Hon. Committee, that unless the relative powers of the British and Dutch be defined, the British Government in India, acting under orders of restriction and prohibition, cannot be a match, with regard to our political

(a) Zie Bandjermasin 73-74.

(b) Verg. Malakka-Riouw 36-37. 
and commercial interests, in the Eastern seas, for the Dutch Government in that quarter, whose merits will be estimated by their sovereign, according to the extent of the aggrandizement which they may effect of the Dutch power and influence. Hence it is evident that the consequence of neglecting this matter in Europe, and sending restrictive orders to your governments in India, would unavoidably be the establishment of the supremacy and monopoly of the Dutch in the Eastern seas.

I2. The orders and observations of your Honorable Committee, shall be communicated to sir T. S. Raffles. On the subjects discussed in the Memorandum from the Government of the Netherlands; and on the affairs of Padang and Palembang, we have already addressed your Honorable Committee fully in former communications.

Bijl 3. bl. 60 noot $a$. Brief van onzen ambassadeur te Londen dd. 14 Januari $1820 \mathrm{n}^{\circ} 10$ aan onzen minister van B. Z. (B. Z.):

Lord Castlereagh (qui part demain pour aller prendre pendant quelques jours le divertissement de la chasse au fusil dans le comté de Norfolk chez son beaufrère, le lord Suffield, lieutenant de cette province) étant venu à Londres mecredi $(a)$, j'ai profité du loisir compératif que lui laissent les vacances du Parlement pour le voir, et j'ai passé une heure avec lui hier matin. Je l'ai trouvé très-content, comme il a lieu de l'être, de l'état des choses dans ce pays ci, et sur le tout assez satisfait de la tournure qu'elles prennent en France et en Allemagne.

...... Après que lord Castlereagh m'eut entretenu de ces divers objets avec sa sincérité et sa confiance ordinaires, je fis tomber la conversation sur nos prochaines conférences au sujet de nos affaires aux Indes Orientales, et je vais avoir l'honneur de rapporter à Votre Excellence la substance de ce que sa Seigneurie me dit sur cette matière importante. De concert avec Mr Canning il espérait, me dit-il, pouvoir entamer la négotiation en nous faisant quelque proposition spécifique au moins il s'en flattait, sans pouvoir toutefois me répondre absolument qu'ils parviendraient, d'ici à l'ouverture des conférences à fixer leurs idées jusqu'à ce point. Il m'assura que désirant sincèrement la conclusion d'un arrangement équitable et mutuellement avantageux, je pouvais compter qu'ils tâcheraient de ne nous demander aucun sacrifice trop onéreux, mais qu'il ne pouvait me déguiser que l'époque

(a) Woensdag 12 Januari 
à laquelle cette négotiation aurait lieu, nous était désavantageuse. Vous savez, me dit-il, qu'il y a toujours dans ce pays-ci l'une ou l'autre idée majeure qui prédomine et prévaut pendant un certain espace de temps. Aujourd'hui cette idéelà, c'est la persuasion, certainement exagérée, où est la masse du public que le commerce est dans un état de souffrance extrême. On veut absolument y remédier, trouver de nouveaux débouchés pour nos productions etc. etc. et de toutes sortes de moyens seront proposés à cet effet au Parlement. On jalouse votre commerce dans l'Archipel Indien, on vous accuse de vouloir l'étendre à notre préjudice et dans le but de nous en exclure, et ce sera pour nous (Ministres Anglais) une tâche très-pénible que d'avoir à lutter dans le Parlement et le public contre ce préjugé. Il faudra de votre côté y faire quelques sacrifices, et vous bien convaincre qu'il vous importe essentiellement dans vos relations présentes et futures avec ce pays-ci de ne pas heurter de front l'opinion public prédominante, qu'il est presque aussi important pour vous que pour nous-mêmes de ménager. Je vous prie de mander cela à $\mathrm{M}$. le Baron De Nagell et de l'inviter de ma part à prendre ceci en considération. -

Il était de mon devoir, Monsieur le Baron, de vous transmettre presque littéralement ces expressions de lord Castlereagh, parcequ'il est essentiel, que vous soyiez exactement informé de l'esprit dans lequel cette négotiation délicate et épineuse va s'ouvrir ici et des sentiments que les Ministres Britanniques y apportent.

Bijl. 4 bl. 60 noot c. Antwoord dd. 25 Januari 1820 No 12 van Buitenlandsche Zaken aan onzen gezant te Londen op het voorgaand schrijven (B. Z.) :

Votre Excellence croira aisément, que la substance de la conversation qu'Elle a eue avec lord Castlereagh au sujet des négociations futures, pour régler nos intérêts mutuels aux Indes Orientales, qu'Elle m'a communiqué dans Sa depêche $\mathrm{N}^{\circ}$ Io, est de nature à commander les plus sérieuses méditations et je ne saurais m'empêcher de communiquer à Votre Excellence le résultat des miennes. D'abord j'observerais que le point de départ de lord Castlereagh parait être que nous devons faire des sacrifices, parceque l'époque où ces négociations auront lieu ne nous est pas favorable sous le rapport de l'opinion momentanée qui existe en Angleterre que le commerce est en souffrance, que l'on cherche des nouveaux dé- 
bouchés pour les productions Anglaises, que l'on jalouse notre commerce dans l'Archipel Indien, dont on nous accuse de vouloir exclure les Anglais.

Si lord Castlereagh veut se mettre un moment à la place que j'occupe, quel sera alors ce point de départ? Il dirait les sacrifices que les circonstances malheureuses ont causés aux Pays-Bas depuis 37 années sont énormes. Ces sacrifices sont faits et il ne faut pas récriminer, mais de quelles manières pourrait-on justifier des sacrifices nouveaux. Les Pays-Bas ne reclament point ce qui ne leur appartient pas; ils ne demandent qu'à conserver les débris de leur immense fortune. Un employé de la Compagnie des Indes Anglaises, esprit turbulent et brouillon, échauffe une querelle, et accuse audacieusement les vues du Gouvernement des Pays-Bas.

Par ses intrigues et ses délations il envenime les esprits, et pour les tranquilliser, il faudra que les Pays-Bas fassent des sacrifices.

Mais où conduirait cette logique?

A peine les sacrifices seraient-ils faits, qu'un autre employé trouverait des nouveaux motifs de plaintes en calomniant et surement l'exemple une fois admis, il serait trop tentant pour ne pas être suivi.

Si lord Castlereagh se trouvait à ma place, il s'apercevrait bientôt, que l'on n'y est pas placé sur un fauteuil de roses.

Les plaintes amères du commerce vous trompent jour et nuit. Le préjugé que le commerce et les manufactures de la Grande Brétagne écrasent les autres dans les quatre parties du monde est nourri, propagé, et retentit non seulement de tous les coins du Royaume, mais encore de quasi tous les coins de l'Europe. Ah, monsieur le Baron! Si lord Castlereagh se trouvait à ma place, voudrait-il, pourrait-il proposer au Roi son maître d'admettre en principe que nous pouvons faire un sacrifice, qui ne serait pas trop onéreux?

Je ne connais pas suffisamment ni le commerce de l'Archipel de l'Inde, ni les concessions réciproques que l'on peut se faire; mais je connais l'esprit juste et claire de lord Castlereagh et je m'assure qu'après mûres délibérations, son équité sera victorieuse des calomnies et des intrigues et qu'il admettra en principe que les futures négociations doivent être basées sur les droits respectifs, l'intérêt mutuel, et des concessions compensées.

Si Votre Excellence veut se faire remettre sous les yeux la reponse que j'ai faite à lord Clancarty le 3 I Août dernier, elle trouvera que le Roi a adopté la proposition de traiter 
d'une convention générale et positive touchant les intérêts réciproques dans les Indes Orientales sur les bases énoncées plus haut, et assurément Elle n'y en trouvera point d'autres.

Bijl. 5 bl. 64 noot $a$. Het rapport van onzen gezant te Londen dd. 8 Februari 1820 No 29 (B. Z.):

Je communiquai hier à lord Castlereagh le contenu de la dépêche de Votre Excellence $\mathrm{N}^{\circ}$ I 2 du 25 du mois dernier sur les affaires aux Indes Orientales. Lord Castlereagh me dit qu'il ne croyait pas à s'être servi de l'expression de sacrifices; qu'on n'était pas en droit ici et qu'on ne s'était pas proposé de nous en demander; qu'il avait seulement voulu dire qu'il espérait que nous ne perdrions pas de vue la position dans laquelle le Gouvernement Britannique se trouvait sous le rapport indiqué dans ma dépêche $\mathrm{N}^{\circ}$ Io du 14 , position qui lui imposait la loi d'une extrême circonspection dans toute cette affaire, et qui était telle que si on ne parvenait pas mutuellement à s'entendre il ne resterait d'autre alternative que de laisser les choses dans leur état actuel, ce qui serait certainement fâcheux pour les deux parties. Ma réplique fut que je ne prétendais pas disputer sur les mots, qu'il était possible qu'il n'eut pas employé celui de sacrifice dans le sens où il se trouve dans la dépêche $\mathrm{N}^{\circ} \quad$ I 2 du 25 Janvier, mais que j'étais bien sûr qu'il me rendait la justice de croire que je mettais le plus grand soin à rendre à Votre Excellence avec une exactitude scrupuleuse ce qui se passait dans les conférences que j'avais avec lui, et que je croyais pouvoir me flatter qu'en général, et autant que la faillibilité humaine le comporte, mes rapports étaient aussi fidèles qu'il était dans mon intention de les rendre tels. Je viens de relire celui précité $\mathrm{N}^{\circ}$ Io et tout ce que je puis vous dire c'est que si j'avais encore aujourd'hui à rendre compte de cet entretien et de l'impression qu'il fit sur moi, je n'y changerais pas un mot.

Sa Seigneurie me dit encore dans notre conversation d'hier qu'Elle avait trouvé fort naturel notre désir de renvoyer les conférences d'une couple de mois; que l'absence de M. Falck suffisait seule pour justifier ce désir, et qu'Elle ne prévoyait pas de difficulté à fixer l'ouverture des négotiations au commencement d'Avril: que s'il se présentait à cet égard quelque objection, Elle aurait soin de m'en prévenir á temps.

Bijl. 6 bl. 67 noot c. Rapport dd. 13 April 1820 van ambassadeur Fagel aan Buitenlandsche Zaken (B. Z.): 
Ayant vu lord Castlereagh ce matin, je pris occasion de Lui dire un mot au sujet de l'ouverture de nos prochaines conférences sur les affaires des Indes Orientales. Sa Seigneurie me donna à connaître, comme je m'y attendais, que vu l'exigence et l'importance des délibérations parlementaires qui vont occuper l'attention du Ministère, et attendu de plus que M. Falck n'était pas encore revenu de Vienne, Elle pensait qu'il serait expédient de remettre ces conférences jusque vers la fin de la session du Parlement, c'est-à-dire du mois de Juin. Ce retard est fâcheux, mais il était inévitable, et il aura au moins l'avantage de donner à M. Elout plus de temps pour se concerter avec M. Falck. Votre Excellence jugera sans doute à propos de porter ceci à la connaissance de ces messieurs, surtout de M. Elout, qui pensait, si je ne me trompe, à se rendre ici dans le courant du présent mois.

Bijl. 7 bl. 71 noot $c$. Uit Fagel's rapport dd. 13 Juni 1820 aan Buitenlandsche Zaken (B. Z.):

La malheureuse affaire, qui occupe exclusivement le public reste toujours en suspens. Le débat dont elle devait être l'objet dans la Chambre des Communes vendredi passé y fut de nouveau ajourné ce soir-là (sur la motion de lord Castlereagh) jusqu'à hier, et hier il l'a de nouveau été jusqu'à vendredi prochain. Ces délais prouvaient seuls ce que les Ministres ont communiqué hier aux deux Chambres, savoir que la négociation, qu'on disait peu avancée avanthier, et rompue hier, est en train $(a)$. L'on apprend de plus que dans la journée d'hier le Duc de York $(b)$ a vu la Reine, chargé, à ce que l'on croit, de quelque proposition. $\mathrm{Je}$ ne dois pas cacher à Votre Excellence, que l'opinion publique, non seulement dans la basse classe, mais même dans la moyenne, et dans les Provinces peut-être encore plus qu'à Londres, se prononce hautement en faveur de la Reine. On a tout lieu de croire que telles sont aussi les dispositions de la majorité de la Chambre des Communes, et c'est sans contredit à cette circonstance, encore mieux connue (comme de raison) du Ministère que du public, que doit être attribué le progrès quelconque qu'a fait la négotiation. L'on commence à croire assez généralement que ce sera la Reine qui

(a) Men zie over deze mislukte poging in Castlereagh's huis om tot een vergelijk te komen, Walpole I 578.

(b) Oudste broeder des Konings.

7• Volgr. II. 
l'emportera dans cette lutte. Le courage qu'Elle a montré en se rendant ici, malgré tous les obstacles, eut suffi dans une nation telle que celle-ci, pour augmenter le nombre de ses partisans. On est curieux à présent de savoir comment le Ministère se tirerd de la difficulté des papiers scellés sur la table des deux Chambres, et qu'il s'agira d'en retirer. En attendant la Reine a quitté la maison de l'Alderman Wood (a), et est allée en occuper une également petite dans les environs. de Portman Square. La tranquillité publique n'a plus été troublée depuis les excès populaires dont je faisais mention dans mon dernier rapport. Plusieurs des principaux hôtels de Londres en ont souffert, notamment celui du marquis de Hertford où la populace s'est portée à une heure du matin $(b)$, et où elle a failli enfoncer les portes. La Marquise n'était pas. encore couchée et le plancher du salon où Elle se trouvait fut dans un instant tout couvert de briques, de boue et de débris des carreaux de verre des fenêtres. Il doit y avoir après-demain un grand drawingroom en gala pour célébrer l'anniversaire du Roi, et l'on est assez intrigué de savoir si cette journée se passera tranquillement.

Bijl. 8 bl. 91 noot $a$. Brief dd. 1 Maart 1821 van den Britschen gouverneur in Rade aan het bestuur der Oost-IndischeCompagnie te Londen (B):

We have the honour to acknowledge your letter of the 8th-20th August, I 820 respecting the points in controversy between us and the Netherlands authorities in this quarter $(c)$.

2. It does not occur to us that we can throw on the subject any light additional to that in which we endeavoured to display it by our letter of the $17^{\text {th }}$ June last $(d)$. The statements, therein contained would, we trust, be received by your Honourable Committee not as advanced in a partial spirit to uphold a particular opinion, but as the most candid exposition of facts which our judgment and information could supply for your satisfaction.

3. Acquainted as we are with Mr. Elout in public trans-

(a) A(bsolute) $W$ (isdom) werd zijn spotnaam, nadat Brougham hem aldus in het Parlement had tentoongesteld. Wood had de koningin gastvrijheid verleend in zijne woning, gelegen in Zuid-Audley straat te Londen. Men zie over hem Walpole I 568.

(b) De bedoeling is één uur na middernacht.

(c) Deze brief is opgenomen onder bijl. 62 van Singapore I.

(d) Deze brief is opgenomen onder bijl. 65 van Singapore I. 
actions, we are not surprised at the appearance of frankness which he assumes in his conferences with His Majesty's plenipotentiaries. Faith in that show of fairness, with which the wily negotiator would always veil his hostile feelings, would be difficult for us to exert after our experience of his conduct during the arrangements with our Commissioners in Java. A remark, however, must be 'made upon the documents which he has adduced to prove the non-existence of any wish to restrict the commerce of our country. It is true, license for that commerce is declared in the treaties with Sambas, Mampawa, and Pontiana. But this was not done till the attempts to shut the British from trade with those territories had been made and had been resisted in a manner that satisfied the Dutch the point could not be carried; a conviction the more operative from other embarrassments which were at the juncture thickening round them.

4. With respect to Riouw and Lingin, the article relied upon as manifesting such equity seems to us to have been merely a dexterous compromise by which an ostensible freedom at the above ports (easily nullified as to effect by the strong garrisons intended to be kept there) was to cover an interdict of commercial intercourse on the part of British subjects with that undefined extent of territories left open to be pronounced by the Netherlands Government as coming within the description of dependencies on the Johor empire.

5. The object of the Dutch in the treaty with Riouw was to abrogate the treaty entered into by the Sultan with Major Farquhar. Had the Dutch only sought, as they professed, to give renewed activity to an old and still existing treaty with the Sultan it would have been unnecessary to proceed to Riouw with an overwhelming force. It was a novel treaty which they at that time required the chief of Riouw to subscribe. They imposed it on him by violence. He asserted the fact as his excuse for abandoning the engagements with Major Farquhar, and urged in proof the condition extorted from him of the cession of half his revenues. The laxity of the Malays in their representations would have rendered this apology of little weight had not the Chief and all the other native authorities been subsequently forced to flee from the oppression exercised upon them. (a).

6. We are not conscious that these observations are influenced by prejudice. It is necessary that we should not disguise to

(a) Zie voor het hier gebeurde het $\mathrm{II}^{\bullet}$ hoofdstuk van Malakka-Riouw. 
your Honourable Committee or to ourselves the inferences which circumstances unavoidably present. If there be a jealously on the part of the Dutch approaching to enmity, it behoves to look to their future means of annoying us: and on this head, the possession of Singapore cannot be indifferent, as the island, commanding the straits of Malacca, contains a safe and spacious harbour for ships of war.

7. The exercise of a vigilant perspicacity cannot in any degree affect that urbanity of correspondence which we regard as no less becoming your Government than conducive to the public interest $(a)$. In any services which may promote reciprocal conciliatory sentiments we have never been backward. It will be known to your Honourable Committee that on a late solicitation from Baron Van der Capellen to aid him with salt, of which a sudden and distressing dearth had taken place in Java, we tendered to His Excellency about 3000 tons at what the making it had cost us. The Dutch Government declined the offer, intimating that the price was too high. Any greater sacrifice of your funds (for you were to be at the loss of a great profit which you could secure by the home sale) did not appear to us justifiable: but we hope that in going the length of the above proffer we testified on the part of the Honourable Company a very unequivocal earnestness to assist the Netherlands Governor-General (b).

8. On our proceedings in the Political Department of the 26th August last your Honourable Committee will observe that His Excellency Baron Van der Capellen addressed us on the subject of a letter stated by him to have been written by the Tomongong of Singapore to the Sultan of Sambas, and took occasion to complain of the injurious tendency of that communication $(c)$. In reply we informed His Excellency that supposing the letter in question, as stated by him, to have been from the Tomongong of Singapore, we were not in possession of any information from which we could imagine that it was countenanced bij any British functionary. We assured His Excellency at the same time that we should entirely disapprove and reprobate any proceeding tending to excite opposition to the Netherlandish Government on the part

(a) Dit heeft betrekking op de herhaaldelijk door het Londenseh bestuur uitgesproken waardeering over den toon der Calcuttasche correspondentie met Batavia, eene waardeering, die tevens natuurlijk eene beleefde aansporing inhield. Zie o. a. \$ 6 van den sub 56 Singapore I weergegeven brief.

(b) Verg. Opvattingen 349 ; ov. 9.

(c) De hier bedoelde correspondentie in Singapore II 353-354; ov. 41-42. 
of the states in the Indian Archipelago with which he had formed connections.

9. It will be satisfactory to your Honourable Committee to learn that we have since been informed by sir T.S. Raffles that no such communication on the part of the Tomongong of Singapore had been made with his knowledge or countenance, nor did he think it could have been made with that of Lieutenant-Colonel Farquhar in as much as it would have been in direct opposition to the spirit of his instructions. We have the honour to send as numbers in the packet copies of $\operatorname{sir}$ S. Raffles' letter here referred to, and of the letter which we addressed to the baron Van der Capellen, enclosing a copy of it for his information. We have also the honour to transmit a copy of Lieutenant-Colonel Farquhar's answer to the reference which we ordered to be made to him at the same time that we wrote to sir T. S. Raffles $(a)$.

IO. With advertance to the subject of the $24^{\text {th }}$ paragraph of the despatch from your Honourable Committee to which we have now the honour to reply $(b)$, we propose to submit our sentiments on that question in a separate address as soon as we shall, in compliance with your Honourable Committee's orders, have collected the information contained on our records as to the value of the possessions of the Dutch on the continent of India $(c)$.

Bijl. 9 bl. 100 noot 6. De Letter from the Chairman and Deputy Chairman of the Hon. the Court of Directors of the East-India Company to the Rt. Hon. George Canning, President of the Board of Commissioners for the Affairs of India luidt aldus:

East-India House, $22^{\mathrm{d}}$ Dec. 1820.

Sir: - The Court of Directors of the East-India Company have unanimously requested us to convey to you the expression of their deep regret at your retirement from the high public station of president of the Board of Commissioners for the affairs of India; and at the same time to testify to you the sincere respect with which they have been impressed, by the able, upright and conciliatory manner in which you have discharged the duties of that station. The functions of

(a) Nochtans had Farquhar wel degelijk van de correspondentie geweten! Zie de aaugehaalde bladzijden in Singapore III.

(b) Namelijk over de Nederlandsche bezittingen in Vóór-Indië: zie bl. 528 Singapore I; ov. bl. 140.

(c) Dit is geschied bij schrijven dd. 1 Juli 1821 in Factorijen I bijl. 2. 
the rt. hon. board, over which you have presided for a period of nearly five years, have been exercised with so much candour and courtesy, as well as with such invariable attention to the interests both of the public and the Company, that they have been almost entirely divested of the invidious character which must ever, in some degree, attach to a controlling board. We reflect with peculiar gratification, that, under your auspices, Company's servants have been selected by the Court of Directors for the distinguished appointments of governors of two of the principal settlements in India, and have been cheerfully recommended by you to his Majesty for his gracious approbation. Whilst we assure you, in the name of the court, that you carry with you their sincerest wishes for every possible happiness, we desire individually to offer you our best acknowledgments for the attention and urbanity which we uniformly experienced in the course of the communications which we have had the honour to hold with you, and which have been equally felt and acknowledged by our predecessors in the chairs.

We have the honour to be, sir, vour most abedient bumble servants

George Abercrombie Robinson. Thomas Reid.

The Right Honourable George Canning \&c. \&c. \&c.

Dit schrijven en het breede antwoord van Canning op bl. 416-417 van The Asiatic Journal, dl. XI.

Bijl. 10 bl. 106 noot b. De brief van 5 Januari 1821 van Clancarty aan Castlereagh luidt aldus (Corr. 341):

To you, who are acquainted with the manner in which this country is governed by separate departments, without mutual consultation or even communication, it will be no surprise that, notwithstanding Nagell's signature of the note to me of the $9^{\text {th }}$ November, wherein a right is asserted by this Government of continuing the trade in Slaves, except directly with Africa, he should now agree with me in thinking it clear that the Treaty of 1818 forbids all such right. Considering that my energetic note of the 23 rd December, endeavouring to enforce this latter interpretation, had been sufficiently long before this Government, I called upon him on Wednesday last to urge the issue of an early and favourable answer, when he told me that he quite agreed in the view I had 
taken upon this subject, and requested me to talk the matter over with Falck, with whom he also would take an early opportunity of conversing upon it.

I accordingly went immediately to $\mathrm{M}$. Falck. He at first talked of the necessity of a new treaty, in order, if it should be found fit, to explain the intention of the parties in the enlarged sense upheld by us; but I immediately told him the existing treaty was already so clear as not to require any explanation; that there could be no doubt of the fulness of the construction as advanced in my note; and that no words, however strong, could render the sense clearer than it already appears, as conveyed by those adopted by the treaty. M. Falck lowered his tone by this, and promised to look into the matter, so as to return an answer without unnecessary delay.

Though M. Falck did not couple the matters together, or attempt to make the one dependent on the other, yet I cannot help inspecting his abortive proposal of a new treaty originated in a hope that, if this business, in which he knows we are much interested, should be again thrown open, it would give an advantage to him in another, on which this Government is extremely anxious, viz., the settlement by Convention of the rights of trade and establishment, particularly in the Indian Archipelago, and generally in the seas eastward of the Cape.

Upon this subject (though, as I said before, without being at all blended with the other) I had some conversation before I left him, with M. Falck: he showed me two private letters, the one from Lord Hastings to M. Capellen, the Governor of Java, the other, the answer to it, dated in April last, from both of which it appears that the two writers expected, and the last particularly, with expressions of some anxiety, at that time speedily to receive the result of the negociations between the two Governments on Eastern concerns.

These papers were professedly, and I believe really shown me by M. Falck for the purpose of proving that neither of the two Governors-General conceived that these negociations were to depend, for their commencement, on any fresh advices from either of them from India; and I must confess they seem to me (Lord Hastings letter particularly) fully to bear or this conclusion. Be this as it may, in the event (which, however, I can scarcely believe will be realized) of any further difficulty being interposed to the admission of our construction of the Treaty of 1818 , on the Slave Trade, you may perhaps be of opinion that some advantage may be 
derived by us on this point, from the great anxiety of this Government to proceed to a settlement on the other; probably therefore, you may think it advisable, if applied to on this score before the Slave Trade point shall be determined, to answer that, desirous as we anxiously are to have all floating questions finally set at rest between the two Governments by Convention, it must still be confessed that this desire has not of late been increased by the manner in which the clear words of a subsisting treaty have been misconstrued by the Netherlands Government.

Bijl. 11 bl. 107 noot a. Clancarty's nota, gedagteekend Brussel 26 Maart 1821, aan Van Nagell luidde aldus (Corr. 380):

Lord Clancarty presents his compliments to M. le Baron de Nagell, and takes the liberty of referring him to his note verbale of the 26 th of February last, by which he sought a personal audience from the King, for the purpose of pressing His Majesty to direct that answers should be given upon some points, (especially that relating to the construction of the Treaty of May, I8I8) and which, it appeared to him, had been left too long in a state of apparent doubt between the two Governments.

Lord Clancarty, aware of the King's regretted indisposition, has not hitherto urged an answer to this note, and had even presumed to hope that the intermediate arrival to him of satisfactory answers upon these points might altogether have precluded him from the necessity of troubling His Majesty with the renewal of a demand for a private audience.

Disappointed in this, having also recently received pressing instructions from his Court, regretting the delays which had hitherto occured, and directing that an additional instance of the infraction of the Convention for the abolition of trade in slaves should be laid before this Government, the substance of which instructions M. le Baron de Nagell will find in the accompanying official note; assured, moreover, of the happy and entire recovery of the King, Lord Clancarty feels it to be his duty to reiterate his request for admission to a private audience of His Majesty, for the purpose of personally urging what are not less the interests of his own than, rightly considered, they are of both Courts; and therefore solicits his Excellency M. le Baron de Nagell to take the King's pleasure on this subject, and he acquaint him (Lord Clancarty) with the time when His Majesty shall be graciously pleased to receive him. 
Bijl. 12 bl. 107 noot $b$. Het rapport dd. 27 Maart 1821 van Clancarty aan Castlereagh luidt aldus (Corr. 379):

Though I have not yet obtained an audience from this King, for the purpose of remonstrating with him upon the unreasonable delays of this Government, yet the note verbale (a copy of which was transmitted in my letter of $27^{\text {th }}$ February, marked private) has been apparently productive of this good, that it has at lenght elicited a satisfactory answer upon the claims of the Commissariat contractors.

The principal object, however, of seeking this audience, viz, the necessity of obtaining from this Government a full admission of our true construction of the Slave Trade Treaty, in accordance both with its spirit and letter, still remains unsatisfied; and, as I am quite clear that no other fair means have. been left untried by me to press an early and favourable decision on this most important point, and moreover feeling the necessity of immediately urging the late violation of the treaty which has occured at Surinam on the consideration of this Government, I have thought it expedient to accompany my note to M. de Nagell on this subject (a copy of which you will find in $\mathrm{N}^{\circ} \mathrm{I}_{3}$ of this date) by a second note verbale, renewing my request for a private audience of His Majesty. A copy of this I send for your information.

I am, however, privately informed that a favourable decision has been made upon the construction of the Slave Trade Treaty. If this second application for an audience shall hasten the only proper satisfactory assurance on this head, it will quite answer my purpose; if not, it is my intention to press this matter still further, even to what may grow to a breach between me personally and this Government, which, however much I sincerely hope it will not take place, as its result would hazard my situation here, yet I shall consider it my duty to incur the risk, rather than admit a point on the clear decision of which the King and his Ministers are so much interested to be longer held in a state of suspense.

Bijl. 13 bl. 108 noot b. Het rapport dd. 17 Maart 1821 van Fagel aan Buitenlandsche Zaken luidt aldus (B. Z.):

Je viens de faire à Lord Castlereagh les représentations auxquelles Votre Excellence m'invite par ordre du Roi dans sa dépêche $\mathrm{N}^{\circ}$ 3I du 9 de ce mois sur l'affaire d'Ayer Bangies et la nouvelle preuve qu'elle fournit des mauvaises dispositions du Sr Raffles. Sa Seigneurie m'a prié d'assurer Votre Excellence, en réponse à cette communication, qu'aussitôt qu'on aurait 
reçu des Indes les informations qu'on en attend, et qui ne sauraient plus guères tarder, on serait prêt ici et même empressé de reprendre les négociations suspendues, et de terminer par là tous ces facheux différends.

A cette occasion Lord Castlereagh m'a informé qu'il allait mettre sous les yeux de la Chambre des Communes la volumineuse correspondance entre ce Gouvernement-ci et les divers Gouvernements étrangers au sujet du commerce des Esclaves. Je savais déjà qu'on était très occupé au bureau des Affaires Étrangères à mettre ces documents en ordre pour cette communication. Lord Castlereagh m'a parlé de plus de la discussion qui s'est élevée à Bruxelles sur l'interprétation d'un article de notre Traité sur la repression du commerce en question, et m'a prié de faire connaître de sa part à Votre Excellence combien il lui serait agréable que cette discussion put être terminée dans le plus court délai possible de la manière qu'il me dit avoir tout lieu de se flatter qu'Elle allait l'être, afin que lors de la remise à la Chambre Basse des pièces officielles susmentionnées notre Gouvernement put y figurer avec tout l'honneur que lui assurera (c'est toujours Lord Castlereagh qui parle) l'interprétation libérale du Traité. Je ne veux pas manquer de m'acquitter de cette commission; observant toutefois que les détails de l'affaire à laquelle elle se rapporte me sont entièrement inconnus.

Je me suis encore chargé à la demande expresse de Lord Castlereagh de prier Votre Excellence de vouloir bien être auprès du Roi l'interprête de la vive satisfaction que cause à sa Seigneurie la convalescence de Sa Majesté.

J'ai trouvé Lord Castlereagh très bien portant mais un peu fatigué de la séance de la Chambre des Communes d'hier soir sur la question Catholique.

Bijl. 14 bl. 110 noot $a$. Het rapport van onzen gezant dd. 2 Mei 1821 luidt aldus (B. Z.):

Ayant demandé et obtenu un moment d'entretien de Lord Londonderry je me suis acquitté hier des ordres du Roi, tels que Votre Excellence me les a transmis dans sa dépêche $\mathrm{n}^{\circ} 55 \mathrm{du} 24$ avril. Je trouvai sa Seigneurie tenant un papier à la main, et Elle me dit en riant et avec sa bonne humeur accoutumée: je ne sais pas ce que vous avez à me dire, mais moi, jai à vous gronder. Je lui répondis de suite sur le même ton, et en lui montrant la dépêche de Votre Excellence que je tenais aussi à la main: je vous en offre autant, Milord. Après avoir ajouté, toujours en plaisantant: qui sera-ce donc 
de nous deux qui commencera à gronder l'autre? Son Excellence me lut une lettre de Mr. Wilberforce (qui était le papier qu'il avait à la main) pleine de doléances sur la non-exécution des traités repressifs de la traité des noirs en général, mais plus particulièrement sur le contenu d'un décrêt du Roi, notre Souverain, relatif au même objet, pris, à ce qu'il semble, à la suite des derniers offices de Lord Clancarty, et qui vient de paraître dans les papiers publics, ayant été (à ce que j'ai compris) tout récemment en discussion entre Votre Excellence et l'ambassadeur britannique. Ne connaissant cette matière que très imparfaitement, et seulement parce que Lord Londonderry m'en a dit en passant, je n'ai ni pu ni voulu m'engager dans cette discussion, mais me suis borné à promettre à Lord Londonderry (conformément à sa demande) de vous mander, Monsieur le Baron, combien cet objet lui tient à coeur, et combien je redoute les attaques auxquelles il s'attend de ce chef dans la Chambre des Communes de la part tant de M. Wilberforce lui-même que de ses nombreux partisans. J'ai pris alors la parole à mon tour et ai représenté à Son Excellence combien la longue interruption de nos négociations sur les affaires des Indes Orientales avait de quoi surprendre et déranger la marche de notre Gouvernement. La réponse fut que j'en savais la cause, qui n'était pas autre que la non-arrivée des rapports qu'on attendait ici de Calcutta, et que c'était là bien véritablement la seule et unique cause $\mathrm{du}$ retard. J'observai là-dessus que ce retard était en attendant d'autant plus fâcheux, que le $\mathrm{S}^{\mathrm{r}}$ Raffles quoique désavoué par son propre Gouvernement ne restait pas moins à son poste et continuait à employer toute son influence à souffler le feu de la discorde entre les employés respectifs dans l'Inde, ce dont devait résulter nécessairement un ferment dans les intelligences entre les deux pays. Ce raisonnement me parut faire impression sur Lord Londonderry qui ne put en nier la justice, m'assurant toutefois que rien ne pouvait être plus éloigné des intentions ou du désir du Gouvernement britannique qu'un tel résultat. Il ajouta néanmoins que la question relative au commerce des esclaves prenait chaque jour dans ce pays-ci un caractère plus grave et plus compliqué, et que d'un autre côté celle de l'arrangement à faire aux Indes Orientales (surtout de la manière dont nous l'avions présentée dans les conférences de l'été passé) embrassait tant d'intérêts et des intérêts si majeurs et délicats pour ce pays-ci qu'à moins que l'autre point (celui du commerce des Esclaves) ne fût réglé d'une manière satisfaisante il n'oserait presque pas, 
dans la disposition actuelle des esprits, reprendre la négociation sur l'affaire des Indes.

Bijl. 15 bl. 111 noot b. De brief van Clancarty dd. 3 Augustus 1821 aan Castlereagh luidt als volgt (Corr. 420):

I beg your attention to my despatch of this date, No $4 \mathrm{I}$. I have found the King (for he stands alone in the business, as all his Ministers assure me) more obstinate than, with his well known disposition, I had even expected him to be on the subject of the Slave Trade. With real deference to your better opinion, mine is that this point must not be relinquished; that, abstracted from the importance of the subject in itself, if we suffer his Majesty to triumph in victory over us on this occasion, he will not fail to wage continual war with us on every future opportunity.

I would, however, in the present instance, begin gently. It may be, as I have suggested in my despatch, that a point of pride withholds him from communicating to us the particulars of the instructions sent out, on which he professes himself so strongly to rely, and that these may be really framed with a view to prevent the future traffic in slaves; and this suggestion is certainly fortified by the fact that Falck, the Colonial Minister, desired Nagell to acquaint me that his report was quite favourable to our objects, and particularly to add that I might be well assured that the instructions he had sent out were amply sufficient to put an entire stop to all further importations of slaves into the Dutch colonies.

I should therefore propose that an instruction should be sent out to me, founded on Nagell's note of the $3 \mathrm{I}^{\text {st }}$ ult., and on the previous correspondence, directing me, both by an official note to the Minister of Foreign Affairs, and in a personal interview which I should be directed to solicit from the King, to assure His Majesty of the entire confidence placed by my Sovereign in the measures adopted by his Court for the execution of the treaty, subsequently to the decree of April I6 last, and that this confidence in the King my master was amply supported by those general assurances of their efficacy, which had been generally notified under the orders of the King of the Netherlands - that the form, however, of the British Government, the universal and anxious interest taken by the British public in this question, the circumstances of the details of every published document issued by this Government for the purpose of carrying the treaty on their part into execution, being manifestly insufficient for this 
purpose - these and other considerations had led my Government, without any distrust in their efficacy, to seek a communication of the instructions sent out to the Dutch subordinate authorities upon a subject in which both Crowns were equally interested, on which the most entire and unreserved confidence must necessarily be presumed to exist between them - a confidence which the Court of Great Britain would always be found ready in the fullest manner to justify by the communication of every law, instruction, or other proceedings for the complete execution on its part of the treaty, whenever such communication should be desired by this Government.

Such is the proceeding which I should suggest on this occasion; and, if the despatch shall be written so as to be communicated in extenso, so much the better. I have proposed that this should be done both by note and interview with the King - the former for obvious reasons common to all Governments - the latter, because the King here is his own Minister in every branch and department of the State, those called his Ministers being little more than mere Chefs de bureau, as is amply proved in this very identical case, in which all those styled Ministers, including the whole Council of State, are with us, the King alone against us.

If you should think this course worthy of adoption, and that it should succeed - well. If, having been promised, it should fail, other measures, which I have already suggested in former letters, will then be to be considered. Of these, should they become necessary, I will hereafter eventually write more at large. Sufficient to the day is the evil thereof.

Bijl. 16 bl. 114 noot $a$. Clancarty's rapport dd. 18 Januari 1822 luidt aldus (Corr. 448):

My despatch $\mathrm{N}^{\circ} 5$, of this date, will show you the result of all our endeavours to procure the detailed instructions of this Government to its Colonies. These, with some remains of that restiveness which has accompanied his Netherland Majesty through the whole of these discussions, he insisted should be furnished to me in Dutch. The translations accompanying them may, however, be relied upon, as they have been finally revised and corrected by M. Falck.

Falck is very anxious that these documents should not be laid before Parliament; and this is not to be wondered at, as more sorry pieces could scarcely have been composed. I therefore expect that, as soon as he shall have seen the King, so as to procure his sanction thereon, he will make 
me a proposal to apply to you to keep them back; but, as they were applied for the very purpose of satisfying the Parliament and public of the loyalty of this Court that, on his authorized and full assurance to me of the King's intentions in all things hereafter to execute the treaty according to ours, its plain construction is that I should write a despatch to you to this effect, which he will probably propose should be laid before Parliament in lieu of the instructions.

This, as far as I am concerned, I shall be willing to comply with, notwithstanding the responsibility; because, from the solemn assertions I have already received from Falck privately that, as long as he shall be Minister of the Colonies, no breach of stipulation shall occur, and from similar assurances from Nagell, I really believe they mean in future to execute the treaty in all its parts. We shall see whether the King will chime in with Falck in authorizing this proposal; if he does, it will furnish an additional guarantee.

Bijl. 17 bl. 115 noot $a$. Clancarty schrijft nl. dd. 22 Januari 1822 aan Castlereagh het volgende over de Slaven-instructiën (Corr. 449):

I have not yet heard anything further from Falck, about keeping back the instructions on the Slave Trade question from Parliament; so that, if he has seen the King, his Majesty has not condescended to his request. In fact, as Nagell acquaints me, the King imagines that Falck's anxiety to suppress these instructions proceeds merely from the reference made in his report to a private letter of the $22^{\mathrm{dn}}$ June, and of which His Majesty is aware that Falck has no copy to produce; and therefore, with that sub-acid humour by which His Majesty is sometimes governed, he has not the least wish to have his Colonial Minister spared from the humiliation of being shown up, for having referred to a private document in a public report, and to a private document of which he does not possess a copy. His Majesty seems quite to overlook the exposure of his own backwardness, or awkwardness, in the execution of his engagements, sufficiently apparent on the face of these papers. The papers are therefore quite at your service, to be laid or not to be laid before Parliament, according to your good pleasure.

Bijl. 18 bl. 116 noot b. De opdracht van Buitenlandsche Zaken dd. 18 Januari 1822 aan onzen gezant luidde aldus (B. Z.):

Pendant le séjour de Lord Londonderry à Bruxelles au 
mois de Septembre, j'ai eu l'honneur d'entretenir S. Ex. sur le désir du Roi, notre Maître, de voir reprendre les négociations sur les affaires aux Indes Orientales. S. Seig: me répondit qu'Elle s'était attendue que je parlerais sur cet objet, qu'Elle s'était informée où ces affaires en étaient, et qu'il paraissait qu'on attendait encore en Angleterre une réponse du Gouverneur-Général de Bengale, laquelle cependant ne pouvait tarder. Te communiquais à S. Ex. l'impossibilité où se trouvait $\mathrm{M}^{\mathrm{r}}$ Elout de continuer à travailler dans ces négociations et j'émis le voeu que le Roi voulut vous adjoindre le Ministre des Colonies; ce choix fut approuvé et je me suis flatté de recevoir l'un ou l'autre avis sur le moment où ce travail pourrait être repris.

Je conçois parfaitement que le moment actuel, où le Parlement va se réunir, il n'y a pas moyen de reprendre ces négociations; cependant il serait désirable de fixer une époque à laquelle ce travail pourrait recommencer et je vous prie de vouloir vous en occuper dans un moment propice afin que de notre côté nous soyons prêts et que rien ne nous empêche de conduire à bonne fin une affaire qui intéresse également les deux royaumes.

Bijl. 19 bl. 129 noot $a$. Het Geheim Kon. besl. dd. 21 November $1823 \mathrm{l}^{\mathrm{a}} \mathrm{Z}^{10}$ luidt aldus (B. Z.) :

Wij enz.

In aanmerking nemende, cat wij op het van Onzentwege kenbaar gemaakte verlangen het Engelsch Ministerie deszelfs bereidwilligheid heeft verklaard om, op het einde der thans loopende maand te Londen de onderhandelingen over de wederzijdsche belangen in Oost-Indië te doen hervatten, welke in den jare 1820 , hebben moeten worden afgebroken.

Hebben besloten en besluiten:

\section{Art I.}

Onze Minister Mr. A. R. Falck wordt benoemd tot Onzen plenipotentiaris om gezamentlijk met den als zoodanig bij. Ons besluit van I 2 Junij I $820 \mathrm{n}^{\circ} 35$ benoemden Ambassadeur bij het Hof van Londen $(a)$, den baron H. Fagel, de in annoI 820 gestaakte onderhandelingen over de Oost-Indische zaken ten einde te brengen op zoodanige instructie en volmacht als door Ons bereids in het evengemelde jaar werden gearresteerd of nader door Ons vastgesteld zullen worden.

(a) Zie hiervoor bl. 68 ; ten onrechte staat daar regel 6 v. b. 22 Juni, m. z. 12 Juni. 
Art. 2.

Wij laten Ons welgevallen, dat hij zich in deze zending doe vergezellen door den zich met verlof hier te lande bevindenden kapitein bij de Oost-Indische landmacht C. P. J. Elout, adjudant van den Gouverneur-Generaal van Nederlandsch-Indië. En zal deze officier, gedurende den tijd, dat hij zich te dier zake buiten het Rijk bevindt, de Indische traktementen, die hem staande zijn verlof slechts voor de helft uitbetaald worden, ten volle genieten.

Art. 3.

Voornoemde Minister zal voor de uit- en thuisreize genieten eene som van twee duizend guldens ééns geld, en voorts honderd guldens per dag, van den dag van zijne aankomst in Londen tot dien van zijn vertrek, wel verstaande dat hij den lande wegens de reiskosten noch van den kapitein Elout, noch van den door hem mede te nemen Amanuensis even weinig iets in rekening zal mogen brengen, als wegens de daggelden ten behoeve van dezen laatsten.

Art. 4 .

De betaling der in dezen benoodigde gelden zal uit de Indische fondsen geschieden door de zorg van het Departement van Publiek Onderwijs, Nationale Nijverheid en Koloniën.

Afschriften enz.

Gegeven in 's-Gravenhage, den $2 \mathrm{I}^{\mathrm{n}}$ November des jaars I823, het tiende van Onze Regering

Willem.

Van wege den Koning

J. G. de Mey van Streefkerk.

Bijl. 20 bl. 131 noot $a$. Brief, gedagteekend Londen 11 Maart 1823 van Wellington aan Clancarty over de ontevredenheid van onzen Koning:

$$
\text { My dear Clancarty, }
$$

London, I Ith March, I823.

I wish to mention to you that I know your King has complained to his intimates of your treatment of and conduct towards him and his government. The complaint is of this kind: that you presume upon old acquintance and friendship to talk to him with more freedom than he likes, or than suits your relative positions, and that your language to him and his government is sometimes not to be borne. This is 
very foolish and ungrateful, but to a wise man is worthy of observation.

Now, my dear Clancarty, allow me who see both and indeed all sides of this question to advise you to avoid as much as possible altercations with the King, and to be very moderate in your language to him and to his Ministers. I should have said nothing upon this subject to you if I had not seen yesterday a series of your despatches upon the Lutine frigate (a), upon the slave trade at Surinam, upon the navigation of the Rhine, Scheldt, \&c, written in a style of familiar acrimony, which the subject and the conduct of the government well deserve, and fully justified by what you believed to be your relations with them; and encouraged, I believe, and as I think I perceive, by the Foreign Department here. But all is not gold that glitters. In my opinion our late friend (b) would have warned you of the position in which you stood in relation to the King, and I should have done so when the information came by chance to my knowledge, if I had not thought that you would have received the warning from the proper authority. As it is, and as I think I perceived, in the despatches which I read yesterday, that, instead of being warned, you had been encouraged and indeed fresh matters of irritation had been suggested to you on the question of the navigation of the Rhine.

I take the liberty of an old friend to give you this warning and advice. You may be as just as strong, but a great deal more polite! From all this you will see that I think you were right and I wrong in the last discussion you and I had together in the room in which I am now writing. God bless you.

Believe me ever your most affectionately,

Wellington.

Clancarty heeft hierop het volgende geantwoord:

My dear Duke,

$$
\text { Bruxelles, I4th March, } 1823 \text {. }
$$

It would be impossible for me by any words to express to you the gratitude I feel for your most kind, most friendly advice. I shall not otherwise attempt it than by assuring you that I shall most strictly and zealously follow it. To persevere in errors which your friendship and good-nature have with such delicacy pointed out, would be unpardonable;

(a) Zie ook over de Lutine de noot $c$ op bl. 121.

(b) Castlereagh (?).

7• Volgr. II. 
by my future conduct it will therefore be my study to avoid their repetition. Nevertheless, I cannot regret what has occured, because it has furnished me with such a valuable testimony of your good opinion, and of the kind interest you are so good as to take in me. Believe me I shall never forget the thorough gratitude I owe you for this signal instance of your regard.

To this King personally I am not conscious of having ever failed in that respect which is his due, and which I am not less led by sense of duty than by real feelings of friendship to pay his Majesty. $\mathrm{He}$ has, however, I know, been much irritated of late against me, it having very industriously been insinuated to him that I am the sole cause of bringing the Congress of Verona on his back in the affair of the prohibitions on river transit. Now, this is partly true; it was my duty to communicate to my chief all the measures which led to this proceeding, and so far I am guilty towards his Majesty. But it was for my chief to decide upon the steps to be taken in consequence of my information. With what delicacy we proceeded, by previous communication and advice, to prevent the King from falling into this scrape, your Grace is already aware. He has, however, for the moment forgot all this, and is now irritated because he has got himself into a disagreeable position, which I did my utmost to prevent him from falling into. With his ministers, I will confess, I have in my notes been harsh at times. When people write arrant nonsense it is difficult to expose the trash they mistake for argument without offending. I shall, however, be most wary in future, and most thankful to you, if you should perceive anything amiss, for a single line of such advice as you may deem requisite.

We are eased for the present here upon the Lutine question; a long despatch from me upon this subject goes by the present conveyance, referring the matter for your consideration. The business is not without embarrassment. On the one hand, the right is, as I believe, ours; and the underwriters will naturally seek to have their own, and bring the matter before Parliament. Thus far as a government, I think there is case enough to lay on the table of the House of Commons, to show that the interests of the proprietors have not been neglected. But then, on the other hand, it is not certainly our interest to show up the King of the Netherlands and his government in an invidious point of view; and again, at this time, when we are so closely knit in continental politics 
with this Court, it may be worthy of consideration whether means may not be taken, by hanging the matter up for the present by reasoned protest under the direction of the civilians, to delay further steps for a time.

In een nader op bl. 70 voorkomend schrijven dd. 18 Maart 1823 vervolgde nog Clancarty:

I did not perceive, in the hurry of despatch, till after the departure of the last messenger, that by omitting to touch upon one part of your Grace's letter to me of the I Ith instant, I was in effect guilty of a piece of tacit injustice.

You state that the style of my correspondence with this government (which you so justly reprehend) may have been encouraged by the Foreign Department. I am not aware that I have even this excuse to plead in mitigation. Enz.

De briefschrijver komt dan op de Irutine-quaestie en andere geschillen terug. Tot dusver was er dus nog geene sprake van heengaan, doch eenige maanden later schijnt onze Koning op nieuw zóó ontevreden te zijn geworden op Clancarty, dat onze vorst George IV wilde dwingen hem terug te roepen, door een Nederlandsch vertegenwoordiger van lageren rang dan ambassadeur te Londen te plaatsen, als wanneer de koning van Engeland hetzelfde zou moeten doen.

Ziehier wat Wellington er over aan Clancarty schreef, dd. 28 September 1823, blijkens bl. 141 van het aangehaald werk:

I have been out of town for the last three weeks, and did not know anything that was passing, till the King sent for me yesterday on my return to town, to communicate to me the letter which his Majesty had written to you, and which Mr. Canning had been directed to retain in his hands until his Majesty would show me the copy of it. I cannot add anything in the way of explanation to what the King says in his letter. It is understood here that there had been some dispute between the King of the Netherlands and you, which His Majesty never had, nor never would forgive; that he was determined to have you removed; and that the appointment of Fagel to the ministry, and the intention to have here only a mission are entertained with that only view.

The removal of Fagel is very disagreeable to our $\operatorname{King}(a)$, and

(a) Zie 's Konings woorden bij Fagel's heengaan bl. 411 van Fagel's ontslag. Over het daar vermelde comediestuk Les Anglaises pour rire leest men in 
he is very desirous of avoiding te receive the insult which will be given to him by the King of the Netherlands altering the nature of the mission by which the intercourse between the two countries has so long been maintained. Under these circumstances the King thinks that the most friendly thing he could do by you was to write to you himself; and he has particularly desired me to tell you that he is quite satisfied that $\mathrm{Mr}$. Canning has conducted himself quite fairly by you in this transaction; and that it is this conviction which has induced the King te come forward upon this occasion, to relieve him from the embarrassment which he must have felt in giving you the advice which the King has given you in his letter.

The alteration of this mission is certainly a new feature in this case. If it is alterred you cannot stay; and I entertain no doubt that the existing crisis must bring one of three results, - either your resignation, the alteration of the mission, or an explanation with the King of the Netherlands, in which he will make known his displeasure with you, and his desire that you should be recalled.

No friend of yours can hesitate respecting the choice to be made; and I recommend you to resign. I cannot tell you how much this has annoyed me, but I am convinced it cannot be avoided.

Clancarty antwoordde hierop uit Brussel dd. 3 October 1823 (bl. 143):

I received your most kind letter this morning. That from his Majesty reached me by the same conveyance, and I send you herewith a copy of the answer I had addressed to his Majesty, and which will go by this messenger; this I hope you will approve.

Under the circumstances there was certainly but one thing to be done, viz., follow the King's and your kind advice. To stay here, or even to attempt to do so, after a pronounced displeasure towards me from this King, which, however it has been covered up by every testimony of personal friendship and confidence by his Majesty here, has certainly been expressed in England, - as sufficiently appears from our King's most gracious letter to me, - would neither have

H. de Balzac's „Albert Savarus": „A la paix de 1815 , on plaisanta durant une année les tailles longues des Anglaises, tout Paris alla voir Pothier et Brunet dans les Anglaises pour rire." Wij zien, dat men er wel langer dan een jaar om lachte! 
entered into my feelings of regard for the public service, or respect for myself. You will see therefore that I have humbly solicited his Majesty's orders for my recall, and thus ends my public life.

To say that I do not feel this, - and far more on account of the source from which this necessary proceeding upon my part flows, and which was the very last from whence I could, or ought to have expected it, - would be to say that which would be very far from the truth. I feel the whole most poignantly. The deceit which, it should seem, has been practised here, adds rather than detracts from this feeling. In this King's conduct to me, I should have said he was aux petits soins with me; and as to the change in the diplomatic relations between the two countries, in a very recent interview with his Majesty, - there being question of Fagel's transplantation to the Foreign Office here, - upon my stating my hopes that this would not lead to any change in the diplomatic relations between the two countries, - the King gave me positively to understand that such a measure was not intended. I should hope therefore so pernicious a proceeding (which I doubt not was once in contemplation) has now been entirely relinquished, and will so be declared, as soon as by my letters of recall, a change in the person of this Majesty's accredited agent here shall have been made known.

In my letter to the King I have not, (because it really is not in the power of words to convey), stated anything like the amount of gratitude I feel to his Majesty for his gracious, condescending, and delicate conduct to me upon this distressing occasion. His letter, and yours, my dear Duke, are real comforts under this trying emergency; and believe me I shall ever feel grateful beyond any powers of expression I can command, for the kindness you have shown me upon this and on all other occasions.

I hope I have not gone too far in the suggestions set forth in the concluding paragraphs of my letter to the King, as directly addressed to his Majesty; if so I should hope your Grace will take an opportunity of pleading my ignorance to his Majesty, as the best excuse I can offer for my conduct.

Onder gelijken datum vroeg Clancarty bij ondervolgend schrijven aan koning George zijn ontslag:

Sire ,

Your Majesty's most gracious letter, dated the $24^{\text {th }}$ September, did not reach me till this morning. 
The kindness and condescension of your Majesty's proceeding in this communication have penetrated to the bottom of my heart, and are felt by me with the most sincere gratitude and devotion.

Much as I feel afflicted with the information of the displeasure entertained towards me by the King of the Netherlands, so graciously and with such condescending attention to my feelings announced by your Majesty, I can well assure you, Sire, that the most honourable distinction you have been pleased to confer upon me, by thus immediately, and with your own royal hand, assuring me of your Majesty's approbation of my public services, conveys with it the best palliative of the distress which I cannot avoid experiencing upon this occasion.

I have been aware, through secret information, that in the month of February last, when the Verona protocol, upon the subject of the river transit, was communicated by me officially to the King of the Netherlands, that his Majesty had taken umbrage at this joint effort of his Allies, and led away by the insinuations of persons here, had at the time been induced to suppose that it was intended to force him on this subject, and that I was the person who suggested this measure and with this view.

That the measure grew out of communications from me to your Majesty's government is most true. These it was my duty to make, but that there was, or could have been, on the part of any of your Majesty's servants the most distant design of trespassing in any manner upon the respect due to the King of the Netherlands, is quite without foundation.

I had hoped, nay and felt convinced, that his Majesty upon very short reflection was thoroughly satisfied upon the subject, because from a very few days subsequent to that period, up to the present moment, I had never ceased to experience from his Majesty every proper testimony of his confidence and condescending friendship. Your Majesty's gracious letter has undeceived $/ \mathrm{me}$, and doubtless under such circumstances there is but one course for me to pursue, that of following, as well from entire conviction of its perfect soundness, as from the deference and obedience which through inclination and duty are due from me to your Majesty, the excellent advice your Majesty has condescended to give me; and I therefore humbly request permission to lay my resignation of the highly distinguished post of your Majesty's ambassador to the King of the Netherlands at your Majesty's 
feet, and that your Majesty will be pleased to issue your commands for my recall at such time as may be judged most eligible for your Majesty's service.

The favourable testimony which $\mathrm{Mr}$. Canning has given to your Majesty of my conduct under him since he has held the seals of the Foreign Department, is very gratifying to my feelings. From him I have constantly, during that period, experienced every degree of confidence and facility which I could have desired for the good progress of your Majesty's affairs at this court.

Any change in the diplomatic relations between the two countries would indeed be a measure most impolitic, especially in the present posture of European affairs. I should hope and believe that any intention, which may have existed in the King of the Netherlands to this effect, has already been relinquished; at least, in a very recent conversation with his Majesty, he gave me to understand that such an intention was not entertained. At all events, when, by the issue of your Majesty's commands for my recall, that fact shall be made known to this court, the main object stated by your Majesty being thus obtained, I should think it little doubtful that under your Majesty's commands the absolute rejection of so pernicious a measure might be easily obtained from this government.

Permit me, Sire, again to express my heartfelt gratitude to your Majesty, for the manner in which you have condescended to act towards me upon this distressing occasion, and for the highly honourable manner in which your Majesty proposes to mark your gracious approbation of my public conduct. Your Majesty's offers are far beyond my merits, and fully equal to anything I could have personnally desired. If I dared to express an additional wish, it would be that my brothers, most loyal and devoted servants to your Majesty, might be placed in heritable remainder to the additional English honour by which your Majesty is pleased to state your intention of distinguishing me; by which means the Irish and Eng!ish honours of my family would become inseparable $(a)$.

This suggestion may be improper: - if so, I throw my self upon your Majesty's goodness to pardon it, and to consider it as already relinquished; again repeating that without it I consider myself more than sufficiently rewarded

(a) Zie de aan Clancarty toegekende onderscheiding in de noot $a$ op bl. 373 (ov. 61) Singapore III. 
for the feeble though zealous services I may have had thegood fortune to render your Majesty.

I have the honour to remain, with the most entire respect and attachment to your Majesty,

Sire, your Majesty's most obedient, humble, and most devoted subject and servant,

\section{Clancarty.}

Uit het vorenstaande blijkt, dat Van Grovestins' mededeeling, alsof het ontslag verband hield met verandering. van ministerie (Singapore II 373, ov. 61) niet juist is. Verder blijkt, hoe klein onze hooggeplaatsten in de maatschappij soms kunnen zijn, als ze den dienst moeten vaarwel zeggen. Dit, zoowel à propos van mijnheer Clancarty, als van mijnheer Fagel. Wat een distress, wat bloedende wonden wegens de verplichting om in ruste te gaan!

Bijl. 21 bl. 133 noot $a$. Het particulier schrijven dd. 28 November 1823 van Falck aan Van Nagell luidde aldus (B. Z.):

Eenig officieel schrijven van UHoogEd.Gestr. zoude heden niets anders kunnen bevatten dan het bericht van mijne aankomst in Londen, na eene zeer voorspoedige reis van dertig uren. Liever onderhoud ik u dus onder de aan het hootd dezer staande rubriek $(a)$.

Uwe dépêche over het rappel had eenen indruk gemaakt des te dieper omdat dezelve door niets was voorbereid geweest $(b)$. Het schijnt namelijk, dat de Westelijke winden de vroegere paketboot lang hadden opgehouden en zoo is het gekomen, dat de brief, den $18^{\text {den }}$ November door den Generaal Fagel afgezonden, te gelijk met de evengemelde dépêche ontvangen is, dingsdag voormiddag. Ik wil niet ontveinzen, dat ik een man van die jaren $(c)$ en van die verdiensten met een innig leedwezen in den staat gezien heb, in welken hem de bekendmaking van 's Konings definitieve intentiën gebragt heeft en van ganscher harte wensch ik, dat het Hoogstdenzelven behage een pleister op die wonde te leggen, welke, zoo niet alle kenteekenen bedriegen, inderdaad bloedende is. Overigens zullen zijne rescriptie en zijn aandrang om de brieven van rappel toch onverwijld te bekomen, daarvan tot genoegzaam getuigenis strekken. Hulp in de onderhandeling. heb ik van mijn mede-plenipotentiaris volstrekt niet te ver-

(a) Boven den door mij gelezen brief staat enkel Vertrouwelı̈k.

(b) Namelijk van Fagel's terugroeping. Zie Fagel's Ontslag 405.

(c) Fagel zou in Maart 1824 worden 59 jaar. Verg. Sluiting 250; ov. 12. 
wachten. Hij - verzocht dat ik zulks zelf zoude beoordeelen naar de gemoedsgesteldheid in welke ik hem aantrof. Ik reken dus alleenlijk op eene presentatie bij de heeren Canning en Wynn, en op eene onverschillige bijwoning der eerste conferentie; immers zoo deze eenigzins spoedig plaats' vindt. Maar eerstgem. Minister had zich verwonderd getoond toen hem, eergisteren de tijding van mijne op handen zijnde aankomst mondeling medegedeeld werd. In omstandigheden als deze had hij dezelve niet verwacht. Ook zoude hij zich persoonlijk weinig met de zaak bemoeijen en ze aan de zorg van zijn ambtgenoot W. overlaten. Doch deze op zijne beurt, had liever geene onderhandeling gezien en dacht dat het wederzijds beter ware de O. I. kwesties zoo maar onafgedaan te laten. Bij de beoordeeling dezer voorloopige opgaven moet de tegenwoordige stemming van den Ambassadeur zeker in aanmerking komen; maar in allen geval blijft er genoeg over om mij de hier te volvoeren taak als nog moeijelijker te doen beschouwen dan ik ze te voren vond. Ondertusschen heb ik mij te verheugen, dat $Z$. M. de toekomstige beschikking over de vereerende ambassade nog teruggehouden heeft en ik hoop om het belang der negociatie, zoowel als om dat van den negociateur, dat dezelve vooreerst verder geheim blijven zal, hetzij de afzending der brieven van rappel dadelijk plaats grijpe, hetzij eerst na lord Clancarty's afscheid. Met mijne motieven daartoe te ontwikkelen, zoude ik uwe penetratie te kort doen. Ik bepale mij dus, in afwachting, dat $\mathrm{U}$ verslag kan worden gegeven van mijne receptie bij de Engelsche ministers, tot de bijzondere aanbeveling van deze zaak in Uwe zorg en van mijn persoon in Uwe vriendschap, terwijl ik voorts de eer heb van mijne meeste consideratie en hoogachting.

Londen, 28 November 1823 .

\section{A. R. Falck.}

Bij het sluiten dezer verneem ik, dat de heer Canning, uit hoofde van ongesteldheid, heden niet is in de stad gekomen en zelfs de ondersecretarissen van Staat naar buiten ontboden heeft om aldaar met hem te werken.

Bijl. 22 bl. 143 noot $b$. De brief van Buitenlandsche Zaken dd. 22 Januari 1824 aan onze gevolmachtigden te Londen vangt aan met het gevoelen van dezen weder te geven over den afstand van Singapore en Malakka tegen Benkoelen en onderhoorigheden, waarna de depêche als volgt luidt (B. Z.) :

De gronden, die voor zoodanig gevoelen pleiten, afgeleid uit de noodzakelijkheid van het behouden onzer consideratie 
bij de inlandsche vorsten, zijn ongetwijfeld aller gewigtigst, en ik vind mij dan ook door Zijne Majesteit gemagtigd Uwe Excellentie te kennen te geven, dat in het algemeen derzelver wijze van zien de goedkeuring van $\mathrm{Zijne}$ Majesteit wegdraagt. Intusschen heeft eene meer opzettelijke overweging van het gedane voorstel tot ruiling van Benkoelen en verdere Britsche onderhoorigheden op Sumatra's Westkust tegen Malakka en Singapore aanleiding gegeven tot het vlugtig opteekenen van eenige bemerkingen, zooals die vervat zijn in de bijgaande nota, die ik gelast ben aan Uwer $\mathrm{Exc}^{\mathrm{s}}$. aandacht en overdenking te onderwerpen, onder verdere bijvoeging, dat hoezeer over het geheel de geprojecteerde ruiling wel aannemelijk te achten is, daarbij echter niet uit het oog verloren, maar veeleer in verband behooren gebracht te worden, ook andere ruilingen en vooral ook geldelijke tegemoetkomingen en schadevergoeding van geldelijke voordeelen.

Zijne Majesteit vertrouwende op Uwer $\mathrm{Ex}^{\mathrm{s}}$ omzigtigheid en kennis van zaken, deze onderhandeling betreffende, wenscht dus dat Uwe $\operatorname{Exc}^{\mathrm{n}}$, bij het schetsen van het ontwerp van overeenkomst, met welke $\mathrm{Z}_{\mathrm{ij}}$ zich onledig houden, er zich vooral op toeleggen om zoodanig verband te trachten daar te stellen en kunnen zij zich diensvolgens, met in achtneming daarvan, voor gemagtigd houden om eene territoriale ruiling in den geest van het voorgestelde, tot een der bestanddeelen te maken van het voors. ontwerp, hetwelk, onder het oog van den Koning gebragt wordende, Zijne Majesteit alsdan in staat zal stellen. om het werk in zijnen geheelen omvang te overzien en Uwe Excellentien bepaalde voorschriften te doen geworden.

Bijl. 23. bl. 144 noot $d$. De brief dd. 27 Januari 1824 van Buitenlandsche Zaken, waarbij de tweede Nota van Elout op last des Konings aan onze gevolmachtigden werd gezonden, luidde, na aanhef, aldus (B. Z.):

Uwe Excellentien zullen daaruit bemerken: dat, ofschoon men gereedelijk toestemt, dat de afstand van de Ned. bezittingen op de Vaste Kust van Indië is aan te raden, die afstand echter al wederom in verband/beschouwd en behandeld behoort te worden met andere ruilingen van grondgebied en met andere geldelijke aangelegenheden; mitsgaders dat het alweder raadzaam schijnt te zijn deze wijze van zien van toepassing te maken op het al of niet verbinden van vroegere regten en wel meer bijzonder met opzigt tot het verschil over den opium en den salpeter. 
De Koning ziet met genoegen uit het slot van Uwer Exc. rapport het voornemen zijner Gevolmagtigden, om in de nog te houden conferentiën het meest mogelijke te bedingen voor hetgeen dezerzijds zoude worden afgestaan, doch Z. M. vermeent, dat dit doel het best zal bereikt worden door een algemeen overzigt en verband, hierboven en ook bij de vroegere depêche vermeld en Hoogstdezelve heeft mij dan ook dien ten gevolge aanbevolen, Uwe $\operatorname{Exc}^{n}$ vooral uit te noodigen, van er zich op toe te leggen, dat in de conferentiën aan de zaak eene zoodanige wending als de hiervoren bedoelde gegeven worde als meest geschikt schijnt te zijn om eene goede uitkomst te verwachten.

Bijl. 24 bl. 149 a. (N.B. Op bl. 7 laatste regel wordt verwezen naar bijl. 24; bedoeld is daar 25) Falck's particulier schrijven uit Londen aan Reinhold dd. 16 Februari 1824 (B. Z.):

D'après les lignes que vous avez eus la complaisance de m'adresser le lendemain de l'arrivée du capitaine Elout( $(a)$, je crois, Monsieur, pouvoir sans aucune présomption anticiper sur la conclusion du Traité dont le projet a été soumis au Roi et vous demander ce que je devrai faire après que ce traité aura été signé.

Il est superflu de dire qu'un peu plus tôt, un peu plus tard j'aurai besoin d'aller à la Haye et à Bruxelles pour arranger mes affaires particulières et pour aller prendre ma femme. Mais je tiens spécialement et dans l'intérêt public à être présent lorsque mon portefeuille ministériel passera en d'autres mains. Il est fâcheux que la question se complique un peu par l'état de la santé du Roi d'Angleterre. Quand S. M. quitterat-elle Brighton? Quand se sera-t-Elle assez reposée à Windsor pour $y$ recevoir $M$. Fagel avec /ses lettres de rappel et $M$. Falck avec ses lettres de créance? Si cela pourrait avoir lieu vers la fin de Février, c. a. d. peu de jours après celui où je calcule que nous signerons le traité, tout serait à merveille. Ma mission extraordinaire, qui aurait tout juste duré trois mois, serait remplacée par l'ambassade et je partirais de suite pour le continent afin de ne pas faire languir l'aspirant au susdit portefeuille et afin d'être de retour ici et complètement établi vers la fin de Mars. Mais je ne puis vous dissimuler que S. M. Britt. renchérit, comme de droit, sur les goutteux ordinaires par l'excessive incertitude de ses mouvements et de ses décisions. Il est possible que cette audience d'admission se fasse longtemps attendre et alors que de temps perdu que

(a) Zie de noot $b$ op bl. 150 . 
je pourrais si utilement employer ailleurs! Ces considérations me portent à solliciter, sauf votre meilleur avis, une marque de confiance additionnelle. Je désirerai que vous fussiez autorisé à me transmettre mes lettres de créance avec le pouvour discrétionnaire de les présenter aussitôt après la signature si l'on veut bien m'en fournir l'occasion ou de les garder en poche et de partir pour la Haye si cette occasion ne me parâit pas prochaine. L'intérêt de mes finances peut servir de garant que je ne prendrai pas légèrement ce dernier parti et que je hâterai, au contraire, autant qu'il dépendra de moi le commencement de la nouvelle ambassade. Mais j'avoue que je tiens par dessus toutes choses, à la remise régulière de mon portefeuille, dont je crains qu'il n'entre pas dans les vues du Roi de laisser l'interim à Mr. Van Ewyck jusqu'à l'époque fort incertaine de mon admission à Windsor et de mon arrivée à la Haye. J'ajouterai cependant, pour plus grand éclaircissement, qu'il est infiniment probable que cette admission et cette arrivée auront eu lieu avant la dernière semaine de Mars.

Vous m'obligerez beaucoup, Monsieur, en me faisant part des intentions de S. M. à mon sujet aussitôt qu'elles vous seront connues.

Bijl. 25 bl. 196 noot e. Geheime brief geteekend India Board 30 Juli 1824 en East India House, Londen 4 Augustus 1824 aan het bestuur in Bengalen (B):

I. A despatch of this date from the Court of Directors, in the Political Department, conveys to you the ratified treaty of the $17^{\text {th }}$ March, between His Majesty and the King of the Netherlands $(a)$. There are more points connected with the treaty on which we find it necessary to address to you a few observations in the Secret Department.

\section{2. $\{(b)$}

4. His Majesty's government and the Court of Directors have received applications from several British subjects, who are concerned in the spice plantations in the neighbourhood of Fort Marlbro', and are apprehensive of a depreciation of their property, consequent upon the cession of the English factory to the Dutch $(c)$.

(a) Deze brief is hieronder opgenomen.

(b) Reeds afgedrukt in mijne Atjeh-verhandeling onder bijl. 9. De cijfers in de mededeeling aldaar "De Atjeh-paragrafen 3 en 4", moeten luiden 2 en 3.

(c) Over hunne requesten na de sluiting van het tractaat, zie Benkoelen 288; ov. 6. 
It is probable that we may advert to this subject in a future despatch.

5. In respect to the natives, we have nothing to add to our despatch of the 20th March last $(a)$.

6. If the case contemplated in the $15^{\text {th }}$ article of the treaty $(b)$ should, contrary to our expectation, at any time occur as to Sumatra or Billiton, you will immediately assert and exercise the right of re-occupation in the name of England.

7. The treaty was negotiated and concluded with great cordiality, and we have no reason to doubt the sincerity of the Netherland government; and although you have been instructed to pay a vigilant attention to the proceedings of the Dutch after the treaty shall have been promulgated in India, we are desirous that you should not make any demonstration of unreasonable jealousy.

De brief van Directeuren uit het Politiek Departement, waarvan in den aanhef dezer geheime missive wordt melding gemaakt, is veel uitvoeriger, daar het geheele tractaat wordt doorgeloopen. Het stuk aan "Our Governor-General at Fort William in Bengal" van 4 Augustus 1824 en geteekend door "Your affectionate friends" met 6 handteekeningen, luidt aldus (B) :

I. Our last letter to you in this Department was dated the $25^{\text {th }}$ June last.

2. (Aanbieding van het tractaat enz.)

3. The first article $(c)$ of the treaty stipulates for the reciprocal admission of British and Dutch subjects into the ports of the other power upon the footing of the most favoured nation. We are not aware that this stipulation will require any new measure on your part in favour of the Dutch or that it will entitle British subjects to any privilege at Dutch ports of which they are not already in possession. You will take care that the reserve which the article contains as to the «local regulations of each settlement" is not abused. With this view you will inform yourselves of the nature of all existing regulations whereby the British trade is affected, either as to the facility of importation or exportation, or as to the ports to which traffic may be limited, and you will compare these regulations with those to which the Dutch

(a) Bijl. 11 van Factorïen III.

(b) Zie ad art. $18 \mathrm{C}$ bl. 174.

(c) Voor de verwijzing zie men $\mathrm{C}$ op bl. $157 \mathrm{vv}$. 
trade is subjected in British India. This instruction is especially applicable to the ports of Java.

4. The second article as to duties is conformable to the general principle which has been established for many years in British India, though in some degree contravened since the last peace. The reduction of duty, which it will be necessary for you to make in pursuance of the first part of this article will necessarily be extended to those nations which have acquired by treaty the privilege of the »most favoured nation" in the East Indias. These are in fact all the principal powers which have intercourse with India. We are therefore desirous that a new regulation of duties should be applicable generally to all foreign vessels.

5. Care must be taken that the duties payable by British subjects or vessels in Dutch ports shall not be raised above the stipulated proportion by any arbitrary or unequal mode of valuing merchandise previously to charging duties ad valorem.

6. The third article is especially directed against the practice which, according to the statements of various persons who have been concerned in the trade with the eastern islands has been carried to a considerable extent by the Dutch of inducing the native states to make treaties whereby all Europeans but the Dutch are excluded from trade. These statements have been denied by the Dutch and we have certainly had no specific evidence of the fact; but however this may have been, the evil cannot exist in future since all engagements having the effect of excluding British traders from the native ports are annulled by the present treaty.

7. $\}$ (Het $4^{\mathrm{e}}$ en $5^{\mathrm{e}}$ artikel wnothing to observe".)

9. Should any establishment be formed by any English authority in India in contravention of the 6th article; it will be necessary forthwith to direct the abandonment of such establishment. On the other hand, should any establishment be made without authority by the Dutch, the Netherland Government will be called upon to direct that it be abandoned.

Io. The $7^{\text {th }}$ article excepts the Moluccas from the preceding stipulations as to the freedom of trade; this exception you will respect; but you will be careful to observe whether any attempt is made to extend the restriction beyond the limits within which it is confined by the Note, which accompanied the treaty. You will inform us of any indications 
which may be perceived of an intention to relinquish the monopoly of the Spice Islands.

II. These seven articles contain all the stipulations which it has been thought necessary to make with respect to commerce. It is clear that, if carried into execution with good faith, they will remove all the impediments which have been said to obstruct our commerce in the eastern seas.

I2. If any complaint should reach you, whether official or otherwise, of any contravention of the treaty by the Dutch, you will carefully investigate it, and report to us or to the Secret Committee the result without delay, but you must be aware, and cause it to be well unterstood, that no remonstrance founded upon a complaint of this description, can be made to the Netherland Government unless it be accompanied by specific allegations and proper evidence of proceedings not warranted by the treaty.

13. The treaty contains no stipulation concerning the freedom of navigation, as it has not been alleged that British vessels have met with any interruption in any part of the archipelago.

I4. (a).

15. You will, in conformity with the $9^{\text {th }}$ article of the treaty, made arrangements for delivering over to the Dutch, on the $\mathrm{I}^{\text {st }}$ March, 1825 , the factory of Fort Marlbro' and all the English possessions on the island of Sumatra. With reference to the cession of Bencoolen, we request your particular attention to such parts of the Notes exchanged by the British and Dutch Plenipotentiaries as relate to the inhabitants of Bencoolen. You will take care that the intelligence of the intended transfer of authority shall be accompanied by a knowledge of the assurances which His Majesty's Government have obtained from the Dutch in regard to the interests of the natives, and without which we should not have thought ourselves authorized to concur in the cession. Those interests therefore we recommend to your special care $(b)$.

I6. $\mathrm{t} / \mathrm{m}$ 28. (Nadere instructiën betrekkelijk de overgave van Benkoelen; van geenerlei belang meer).

29. In regard to the Ioth article of the treaty (c), we refer you to our observation on article 8 (a) with this addition, that you

(a) Over den bij art. 8 handelenden afstand der Nederlandsche factorijen in Bengalen, zie de $\S$ in Factorïen II 474; ov. 190.

(b) Zie nader Benkoelen $284-285$; ov. $2-3$.

(c) Afstand van Malakka, zie bl. 169. 
will take care that the Dutch conform strictly to the stipulation contained in the latter part of the article.

30. Article I I requires no observation.

32. $\}(a)$.

33. (Strekking van het $\mathrm{I} 3^{\mathrm{e}}$ artikel).

34. (Id. van het $16^{\mathrm{e}}$ artikel).

35. (Het overbrengen der Britsche bannelingen van Sumatra naar eene andere Engelsche bezitting; zie nader Benkoelen, hoofdstuk II).

36. .... Singapore and Malacca will remain subject to your Government.

37. We shall transmit a copy of this despatch to the Government of Prince of Wales' Island.

(a) Handelt over den afstand van Singapore. Te vinden in Singapore II 411 ; ov. 99. 